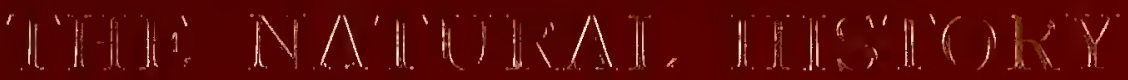

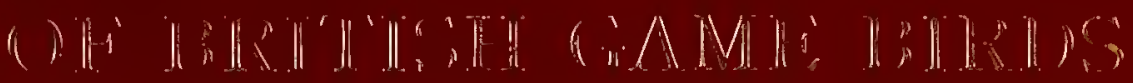

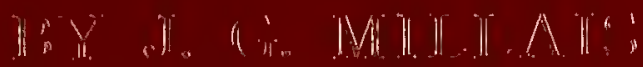




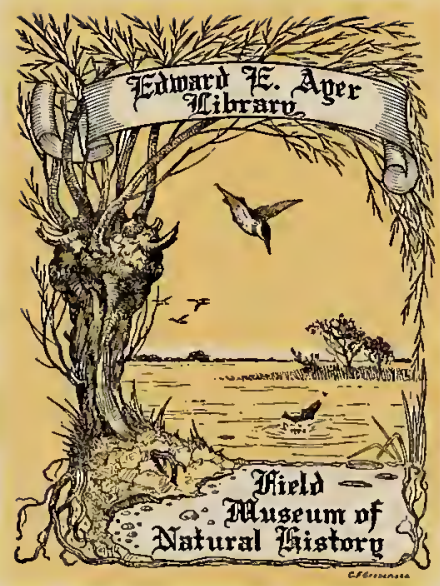




Digitized by the Internet Archive in 2015

https://archive.org/details/naturalhistoryof00john_0 

THE NATURAL HISTORY OF BRITISH GAME BIRDS 
Only Five Hundred and Fifty Copies

of this book bave been printed.

This Copy is No............ 



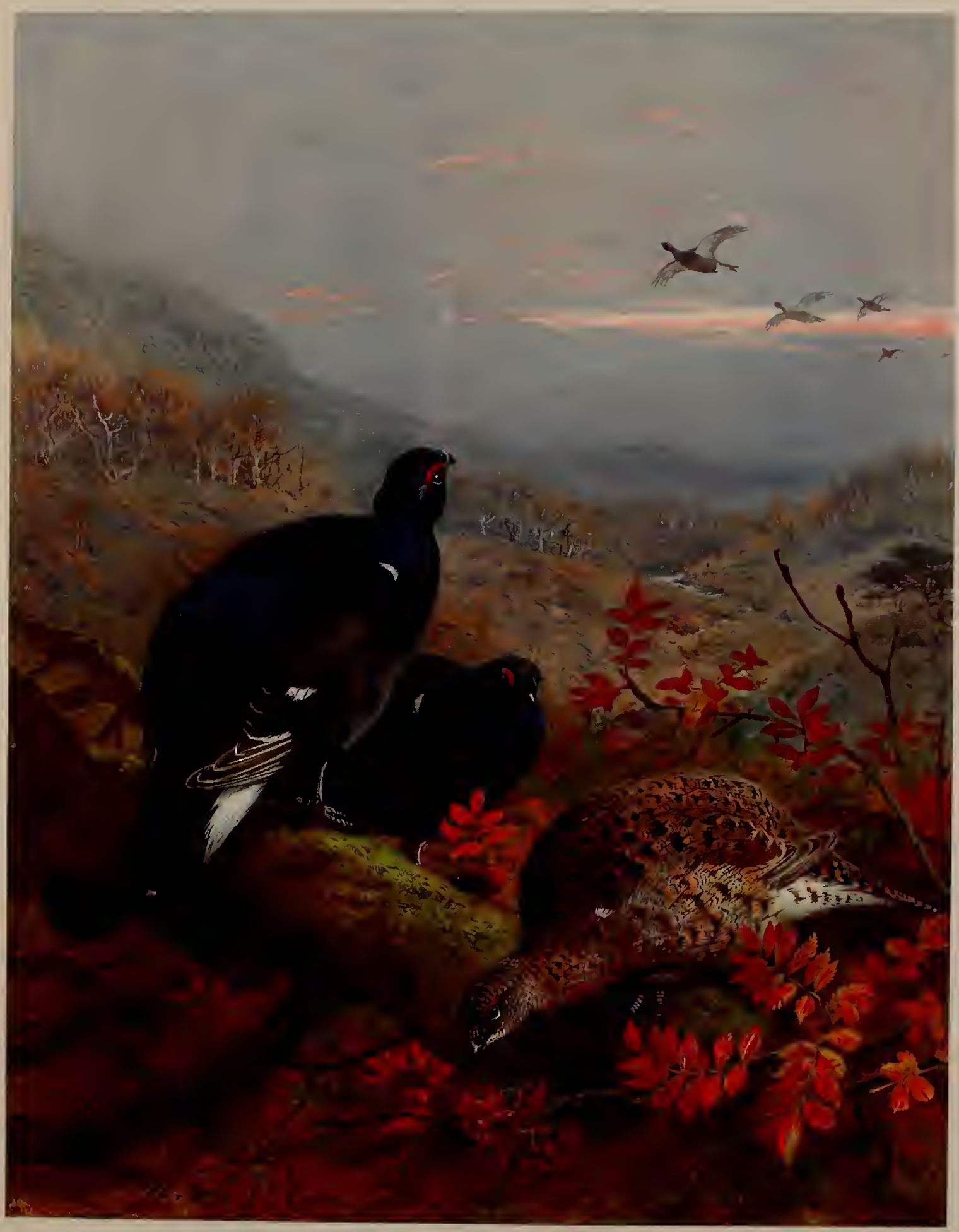

Printed by Albert Frisch-Berlin

THE BLACK GROUSE

Lyrurus tetrix 


\section{THE NATURAL HISTORY OF BRITISH GAME BIRDS}

BY

J. G. MILLAIS, F.Z.S.

WITH EIGHTEEN COLOURED PLATES, SEVENTEEN PHOTOGRAVURES

AND TWO OTHER ILLUSTRATIONS BY ARCHIBALD THORBURN

AND J. G. MILLAIS

$$
\text { liitiil } \begin{array}{r}
66761 \\
\text { c5o-92 }
\end{array}
$$

LONGMANS, GREEN A N C O.

39 PATERNOSTER ROW, LONDON, E.C. NEW YORK, BOMBAY, AND CALCUTTA

$$
\text { I } 909
$$

All rights reserved 
R.B

add.

1909

. 1

QL

690

G7

M) 54 


\section{INTRODUCTION}

E VERY author begins his work full of ambition to make it the best of its kind, but as it proceeds, hundreds of external considerations, chiefly monetary, arise to bar the way. Early in life I learnt that to write and illustrate a first-rate work on British birds would involve a period of at least ten years and an expenditure of not less than $£_{0} I_{5}, 000$. And then who could purchase such a book when it was done? In consequence I prefer to limit my ambitions, and to offer to the public the best I can do by treating separate genera.

The Natural History of the British Surface-feeding Ducks was so successful that I have been encouraged to produce the present work on Game Birds on similar lines, but I trust with superior reproductions. Our birds of the chase are a subject of perennial interest both to sportsmen and naturalists, and I have endeavoured to bring all that is known about them up to date, as well as to add much fresh material regarding the habits, plumages, hybrids, and varieties of a group of which I have made a special study for many years. Again I have had the great assistance of my friend Mr. Archibald Thorburn, whose work amongst his particular family of birds needs no eulogy on my part. It is sufficient to say that his paintings of gallinaceous birds have never been, nor are likely to be, surpassed in our generation.

To render this artist's work as perfectly as possible has been a great difficulty, but I have at length found a form of reproduction which far surpasses the best chromo-lithography or tri-colour processes. It is a new method of direct transmission on to a pure paper of lasting quality. None of the artist's touches, however minute, are lost, nor do other hands mutilate the original picture in course of transmission. Moreover, there is no printed "screen" to trouble the eye. It is, in fact, the nearest thing yet invented to perfect reproduction in colour, and has not, so far as I am aware, been previously used in book illustration. 



\section{CONTENTS}

THE CAPERCAILLIE . . . . . . PACE

THE BLACK GROUSE . . . . . . 18

THE RED GROUSE . . . . . . . 37

THE COMMON PTARMIGAN . . . . . . 63

THE TRUE PHEASANTS . . . . . . . . . 74

THE COMMON PHEASANT . . . . . . 76

THE CHINESE PHEASANT . . . . . . 99

HAGENBECK'S PHEASANT . . . . . . . IOI

THE MONGOLIAN PHEASANT. . . . . 101

THE PRINCE OF WALES'S PHEASANT . . . . . 105

THE JAPANESE PHEASANT . . . . . . . 106

REEVES'S PHEASANT . . . . . . . 107

THE COMMON PARTRIDGE . . . . . . . III

THE RED-LEGGED PARTRIDGES . . . . 126

THE COMMON RED-LEGGED PARTRIDGE. . . 126

THE QUAIL . . . . . . . . . 130 



\section{LIST OF ILLUSTRATIONS}

\section{COLOURED PLATES}

[Reproduced by Albert Frisch, Berlin (W. Villain, London) and André E Sleigh, Led., Bushey, Herts.]

THE BLACK GROUSE (Lyrurus tetrix).

By Archibald Thorburn

Frontispiece

CAPERCAILLIE (Tetrao urogallus).

Face page 2

By Archibald Thorburn

THE RED GROUSE (Lagopus scoticus), Red Form-MARch . . . . . " 38

By Archibald Thorburn

THE RED GROUSE (Lagopus scoticus), WhITE FDRM _. . . . . . . " 40

By Archibald Thorburn

THE RED GROUSE (Lagopus scoticus), BLAcK FDRM _. . . . . . " 42 B)' Archibald Thorburn

THE PTarmigan (Lagopus mutus), Adult Male and Female-Summer Plumage. " 64 By Archibald Thorburn

THE PTarmigan (Lagopus mulus), Adult Male, Female, and Ydung-Autumn By Archibald Thorburn

THE PtarmigaN (Lagopus mutus), Adult Male and Female-Winter Plumage " 68 $B$ y Archibald Thorburn

THE COMMON PHEASANT (Phasianus colchicus) . . . . . . . . " 78

By Archibald Thorburn

PHEASANT MAKING ITS SPRING CALL . . . . . . . . . " 84

By J. G. Millais

PHEASANT IN DISPLAY . . . . . . . . . . . . . 86

B)' J. G. Millais

THE CHINESE PHEASANT (Phasianus colchicus torquatus) . . . . . . . . " 98

By Archibald Thorburn

HAGENBECK'S PHEASANT (Phasianus colchicus hagenbecki) .

" 100

By J. G. Millais 
THE MONGOLIAN PHEASANT (Phasianus colchicus mongolicus).

By Archibald Thorburn

JAPANESE PHEASANT (Phasianus colchicus versicolor)

By J. G. Millais

THE COMMON PARTRIDGE (Perdix cinerea)

By Archibald Thorburn

THE RED-LEGGED PARTRIDGE (Caccabis rufa) .

, 126

By Archibald Thorburn

THE QUAIL (Coturnix communis)

By Archibald Thorburn

\section{PHOTOGRAVURES}

[Reproduced by W. L. Colls, Barnes.]

CAPERCAILLIE IN DISPLAY

By J. G. Millais

CAPERCAILLIE IN FLIGHT

By J. G. Millais

BLACK GROUSE IN FLIGHT

By Archibald Thorburn

BLACK GROUSE AT THE PLAYING GROUND .

By J. G. Millais

GROUSE PASSING OVER HILLY GROUND

By Archibald Tharburn

BREAKING THEIR FLIGHT BEFORE ALIGHTING

By J. G. Millais

COURTSHIP OF THE GROUSE

By J. G. Millais

RESTING ON THE TOPS

By J. G. Millais

A PTARMIGAN PLAYING GROUND.

By J. G. Millais

PTARMIGAN SHOOTING DOWN HILL

By Archibald Thorburn

"THE BOUQUET" .

By J. G. Millais 
List of Illustrations $\mathrm{xi}$

AT THE END OF THE COVERT

Face page 96

By J. G. Millais

PARTRIDGES IN FLIGHT

By Archibald Thorburn

PARTRIDGES IN THE SNOW

By J. G. Millais

PAIRING TIME

By J. G. Millais

, 114

, I 16

A COVEY IN THE SUN .

By J. G. Millais

RED-LEGGED PARTRIDGES RISING .

By J. G. Millais

" 118

, 120

128

BLACK AND WHITE ILLUSTRATIONS

[Reproduced by Emery Walker, Clifford's Inn, London.]

$\left.\begin{array}{l}\text { FEMALE CAPERCAILLIE ON THE NEST } \\ \text { GREYHEN ON THE NEST }\end{array}\right\}$ From Photographis by T. Tait

"10 



\title{
THE NATURAL HISTORY OF BRITISH GAME BIRDS
}

\author{
ORDER : GALLINAE \\ Genus : Tetrao (Linnæus)
}

THE Capercaillie are large birds and comprise four distinct species, all of which inhabit the northern forests of Europe and Asia, namely, the Capercaillie, Tetrao urogallus, whose range is defined below; the Ural Capercaillie, Tetrao uralensis, a much paler bird, with breast and belly almost white, found throughout the Urals; the Slender-billed Capercaillie, Tetrao parvirostus, a species that takes the place of $T$. urogallus, to the north-east of Lake Baikal, but not so far as Kamtschatka; and the Kamtschatkan Capercaillie, Tetrao kamtschaticus, where, as its name implies, it is only known. The middle pair of feathers of the tail are much longer than the other pairs, so that the tail has a rounded wedge-shaped appearance when spread. No inflatable air-sacs nor neck-tufts in the male, nor are the outer flight feathers attenuated.

\section{THE CAPERCAILLIE ${ }^{1}$ Tetrao urogallus, Linnæus}

LOCAL Names.-Capercally, Caillie, Capercailzie, Cock of the Woods, Caper, Capercaille (Argyll); Cabercoille (bird of the woods), Gabur-coille (goat of the wood) (Gaelic); Ceiliog coed (cock of the wood) (Welsh); Tiur (Nomegian); Thiadur, Tjadar, Tedur, Tjalur, Tjoddur, Tidder, Tjur-lian (Swedish); Coq du bois (French); Auerhahn (male), Auerhuhn (female) (German); Gludār (Russian).

Adult Male.-Bill strong, well hooked, bone colour; head, neck, nape, and lower back, slate-grey with fine black markings; scapulars and wing coverts, brown; primaries, dark brown; tail, rounded and black with white bars and pencillings; chest, dark glossy green; lower parts, black, or black well edged with white; chin, black; flanks, slategrey, the longer feathers broadly edged with white, legs well-covered with hair-like brown feathers; over the eye there is a broad scarlet comb, which becomes much swollen in spring. The toes are well fringed at the sides. Length, 35 to 40 inches; wing, I4.5 inches to 16 inches. Weight, 9 to $12 \mathrm{lbs}^{2}$ On the shoulder of both male and female there are one or two pure white feathers, which are very evident in life.

1 The meaning of the word Capercaillie is somewhat doubtful. It has been variously translated as originating from gobur (horse), cabhar (an old man), gabur (a goat), and coille (a wood).

2 I have weighed over roo British specimens and a few Russian ones. 12 lbs. is the largest Scotch male I have weighed, and $x_{4}$ lbs. a Russian example. 
Adult Female.-Bill not so strong as the male; upper mandible brown with bonecoloured edge, lower mandible darkish yellow; throat, buff; neck, buff with black bars edged with grey; mantle, dark buff with broad black bars and brown-grey edges well vermiculated with black; scapulars the same, the larger feathers tipped broadly with white; lower back and rump, buff (concealed), and black edged with grey; tail, well rounded, rich red-brown barred with black and tipped with grey; wings, brown and buff; chest, rich red-brown; flanks and belly, buff, barred with black and tipped with white ; ${ }^{1}$ breast, white ; under tail-coverts, buff, black and white; legs, pale brown, faintly barred with black and grey suffusions of colour; toes, bare and pectinated. Length from 26 to 30 inches. Weight, 4 to $7 \mathrm{lbs}$.

Both adult males and females have a very distinct light and dark form.

There is a great similarity between the young in down of Capercaillie, black grouse, and red grouse. All are light buff in colour, with spots and markings of black, and it is difficult to adequately describe their peculiarities. Young Capercaillie may, however, be recognised by their larger feet and bills and longer legs. At birth they are naturally much bigger than the other species. The loose statement, found in several works, that young Capercaillie in immature plumage "at first resemble females" is quite incorrect. Until two months old they have a very distinct immature dress, quite unlike either parent. It is more like the immature black grouse, being brown and grey, shading to a very light grey on the under parts. The chest is a mixture of reddish brown and buff grey, finely barred with brown-black. Crown of head, brown; neck and nape, grey; throat, light grey. In young males the ear coverts are a very distinct black; wings, a light brown; many of the median coverts with the shaft buff and the points greyish white; legs, grey buff. About the Ist of August the adult plumage is seen replacing the first plumage, and young males weigh about $2 \frac{1}{2} \mathrm{lbs}$; females half a pound less. From this time they increase in weight very rapidly, being full-grown by October Ist. Young males of the first year are easily recognised by their short tails, indifferent plumage, and small bills. Both sexes continue to grow in size and beauty until the third year.

Distribution.-Bones of the Capercaillie have been found in the kitchen middens of Denmark, showing that these birds must have existed in Denmark at an early age, for it is known that the beech groves of the present day have lasted for many generations, since the destruction of the oak forests which preceded them. Before the oak age was the era of pines, in which the Capercaillie lived. The remains, too, of this bird are stated by Professor Newton to be rare in caves, but that he has found relics in the caves of Aquitaine, in the station of Salève (Switzerland), Vererzi (Liguria), Brumigel, and Lacombe-Tayac. Its bones have also been discovered in a cave in Teesdale, Yorkshire. It is curious that no relics of this bird have been found amongst British prehistoric remains, and especially that they are absent from the kitchen middens of Scotland, where we should expect to find them.

At the present day the Capercaillie, in its true and sub-specific forms, extends from Great Britain to Kamtschatka-Lake Baikal being, so far as we know at present, about the eastern limit of $T$. urogallus; to the north it goes as far as $67^{\circ} \mathrm{N}$. In southern

\footnotetext{
${ }^{1}$ In an example of the white type hardly any buff is seen.
} 


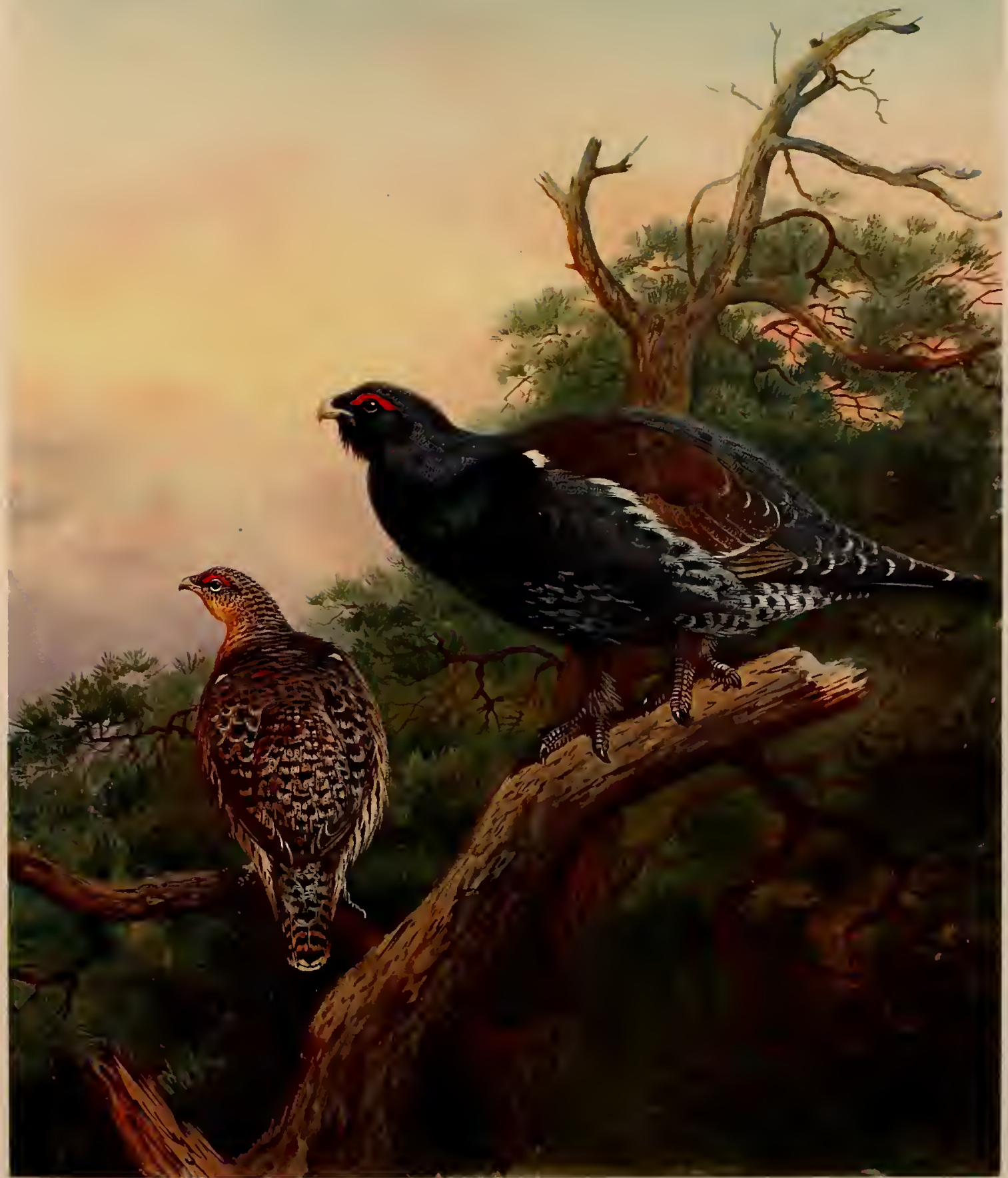

THE CAPERCAILLIE

Tetrao urogallus 

Sweden it reaches its greatest size (males have been described as weighing 16 or 17 lbs.). In general appearance it varies little until the Urals are crossed, when the lower parts of the bird become almost white. It is found in North-East Turkestan and the Altai Mountains. In the extreme east of Siberia it is replaced by a snialler sub-species, Tetrao urogalloides (Middendorf). The species is found throughout the pine woods of Central Europe, and southwards to the Pyrenees and the Alps. It is common in Germany, Austria-Hungary, Poland, and especially so in the Balkans and the Carpathians.

It is doubtful if it still exists in Acanania (Greece), which has been described as the southern limit, although Pennant (Arctic Zoology, 1792, vol. i. p. 365) traces it to the islands of Crete and Milo.

The Capercaillie was known to the ancient Britons under the name of Ceiliog Coed, but of no bird or mammal of importance have we so few references as to its former occurrence and distribution in England. Its extermination was probably coincidental with the destruction of the pine forests. We know, however, that it survived in Ireland and Scotland long after it was extinct in England. Pennant, in his Tour, enumerates it amongst the beasts of the chase in Wales. He says: "The bird mentioned here is the Cock of the Wood, whose habit it is to sit perched on a bough, where it will gaze till it is shot, as it was in the old times, by the bow or cross-bow." By the middle of the seventeenth century it is supposed to have become scarce, and it is probable that it became quite extinct in Scotland and Ireland during the eighteenth century. A few were known to exist near Thomastown, Tipperary, till the year 1760 (Pennant), and Longfield in his treatise on the Game Laws in Ireland says that the "Wild Turkeys" of George III. Act must have been Capercaillie, adding that the species was not extinct so late as 1787 .

"A Catalogue of the Birds of Ireland, by Dr. Patrick Brown, who died in 1790," says Messrs. Ussher and Warren," "showed that this bird still existed in his time (Proc. Dub. N.H. Soc., 18th Dec. 1851); but though 'Wild Turkeys' are subsequently spoken of, we have no distinct evidence that the Capercaillie survived here as late as the end of the eighteenth century."

Giraldus Cambrensis (A.D. 1357), in his Topographia Hibernia (lib. ii. p. 47), says: "Pavones silvestres hic abundant." There is little reason to doubt that the author meant the first words (lit. wood-peacocks) to refer to Capercaillie. F. Willoughby (A.D. I676), John Ray (A.D. 1678), O'Flaherty (A.D. 1684), and J. Rutty (A.D. I772) all refer to the bird as the "Cock of the Wood," and state that it is to be found in woods and mountains, whilst the last named states that they were, at the time he wrote, extinct in Ireland "by reason of the destruction of our woods" (Nat. Hist. of the Connty of Dublin, 1772, vol. i. p. 302).

As regards the history and subsequent extinction of the species in Scotland, we have the admirable little book by J. A. Harvie-Brown, entitled The Capercaillie in Scotland, which gives a very careful summary of the past history and general spread of the species up to the date of writing (1888), since its reintroduction in 1837 . Hector Boetius ( 1526$)$ is the first writer to mention" the Capercaillie: "Unum magnitudine corvum paulo superans Auercalze, i. silvestris equi apelati, solius pinis arboris extremis flagellis

\footnotetext{
1 Birds of Ireland, p. 230.

2 Hist. Scotorum Seot. Regn. Descript., fol. xii. 47.
} 


\section{The Natural History of British Game Birds}

victitantes." Robert Lindsey mentions it as a bird of the table in the time of James V. (I528). ${ }^{1}$

Bishop Lesly ( $\mathrm{I}_{578}$ ) tells us ${ }^{2}$ that it was found in Lochaber and other mountain districts at that time. Mr. Harvie-Brown has discovered an interesting letter written by King James VI. to the Earl of Tullibardine in 1617, in which his Majesty, after a request for a regular supply of the birds, says, "The raritie of these fowles (Capercaillie) will both make their estimation the more pretious," \&c. A perfect chain of evidence exists to the effect that the species was found throughout the fir woods of Scotland until the end of the eighteenth century. Pennant in his Tour in Scotland, 1769, seems to have seen only one, which "was killed in the woods of Mr. Chisholm, to the north of Inverness." It is quite uncertain when and where the last specimens of the original stock were seen and killed in Scotland, neither does there exist in any collection a perfectly authenticated specimen. It is certain, however, that it became extinct about the year 1800; for Montagu, although unaware of its absence in 1802 (Dictionary of British Birds), thus refers to it in his supplement ( $\left.18 \mathrm{r}_{3}\right)$ : "This bird, we believe, is now extinct in the British Dominions." Professor Newton places the extinction in Ireland at about 1760 , and in Scotland "not much later." ${ }^{3}$ The first importation of Capercaillie to Scotland came from Sweden, and were introduced at Mar Lodge by the Earl of Fife in 1827. Two more arrived at the same place in 1829, but the experiment proved a failure. In the autumn of 1837 and the spring of 1838 , forty-eight Capercaillie were obtained in Sweden and turned out at Taymouth by the Marquis of Breadalbane. This proved completely successful; and of their subsequent spread throughout Central Scotland I must refer my readers to Mr. Harvie-Brown's book, which contains all that was known until the year 1888. First extending along Loch Tay to the west, and then all along the Tay and Earn valleys, the species was known in I 888 as far south as Larbert (Stirlingshire), west to Ardkinglass (Argyllshire), east throughout Forfarshire up to Stracathro in Kincardine, and north into Aberdeenshire. Since that date the range of Capercaillie in Scotland has gradually but surely advanced, until the birds have spread through Aberdeen, Elgin, Moray, Nairn, and Inverness-shire.

In Midlothian it is an occasional straggler, about eight records being known. Three were seen in Dumfriess-shire in November 1905 (H. E. Gladstone, British Birds, September 1908). In the south-west, Sir Herbert Maxwell records two shot about 1874 , whilst in Ayrshire a female was killed on December 14, 1905, near Tarbolton.

To-day it is still very abundant about the neighbourhood of Taymouth. The Marquis of Breadalbane writes to me, February 4, 1909, as follows:-

"The awful blow down that we have had here has had a very detrimental effect on Capercaillie, and spread them, one might almost say, far and wide. The first misfortune we had is an old story now-the Tay Bridge gale-then came a serious one that followed it, and another which came from the north-east and did great havoc here. One now finds Capercaillie in woods one never used to see them in before. I certainly think that they are not decreasing but rather the other way.

"One great misfortune regarding the Caper is that when people have shoots they

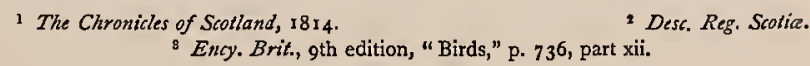




\section{The Capercaillie}

slaughter the hens, whereas, to my mind, Caper hens should be treated like greyhens and spared." Lord Breadalbane kindly furnishes me with particulars of the number of Capercaillie now resident between Killin and Aberfeldy. The estimate of his keepers is "about 760 birds."

All along the main valleys of the Tay and Earn, and also in the Forfarshire woods, especially about Fotheringham, Capercaillie are abundant. I have seen several in a wood close to the sea near St. Andrews, and once saw one crossing the Firth of Tay at a point at least five miles wide. In 1892 I saw the first hybrid black grouse and Capercaillie killed near Nairn, a sure forerunner that the female Capercaillie were pushing westwards from Aberdeenshire. Shortly afterwards I heard of two females being killed near Fort George, where now they are established in the woods. They have extended westward past Inverness, and have reached the valley of the Beauly. A member of the Lovat family informs me that there are now about thirty Capercaillie in the Beaufort woods, and that they will be carefully protected. Capercaillie were introduced into Arran from Taymouth in 1843 , and were abundant there in the seventies, but since that date they have much decreased. It will not be far distant when these birds will frequent all woods in Scotland which are of a suitable size.

There is not the least doubt that the Capercaillie could be successfully introduced into many parts of England and Wales, as many localities are, owing to afforestation, as well suited to its habits as in former times. This is proved by the fact that the only attempt on a generous scale, that of the Duke of Bedford at Woburn, has met with success.

Her Grace the Duchess of Bedford has kindly sent me the following particulars of the introduction of Capercaillie to Woburn: " $1897-9$ cocks, 30 hens; $1898-2$ hens; $190 \mathrm{I}-32$ cocks, 68 hens; I904-13 cocks, Io hens; I907-7 cocks, I4 hens; I9086 cocks, 32 hens; total, 70 cocks and 156 hens. Many of the imported birds probably died soon after being turned out, and doubtless some fell victims to foxes when still weak after their journey. A few blackgame and Capercaillie have been shot by our neighbours at Tingrith and Brickhill. At Stockgrove, where at all events hen birds are preserved by our neighbours, the birds have done very well. In our own woods a few nests are found every year, and one year five nests (of Capercaillie and greyhen) have been hatched off, but the woods are very large and it is difficult to estimate whether they increase in number. All the imported birds come from Hagenbeck."

Habits.-As a general rule Capercaillie, within their present range in Scotland, like to frequent large woods of larch, spruce, and Scotch fir, and for preference those situated on hillsides, as the birds on fine days are very fond of sitting on the tops of trees and enjoying the morning and evening sun in such a position that a wide view may be obtained in all directions. On clear days in winter they may be seen in small parties in such situations, and are then most difficult to approach. It must not, however, be considered that these large fir woods are their invariable habitat. Numbers in autumn, spring, and winter make short local migrations to low-lying woods of oak, birch, and larch, where for a short season they are plentiful. Most of these, especially the old males, return to high ground in late autumn and spring, leaving only a few females 
and an odd male to stay and breed. During fifteen years in which I lived in the haunts of Capercaillie in Perthshire I have seen, when shooting amongst the low-lying woods of the Tay and Earn valleys, numbers of Capercaillie, nearly all hens. Visits to the high grounds and old parts of Dunkeld, Ladywell, Logierait, Crieff, Rohallion, $\&$ c., at the same season, have convinced me that the old males had not changed their habitat, and were still up on the hills amongst the tall timber. In consequence, a heavy toll is taken of the females during the shooting season, whilst the males as a rule escape. By the end of the shooting season at Murthly, I have often seen as many as Ioo hens left for stock, and did not know of a single old male on the ground, and yet the keepers always reported to me the arrival of a dozen males in the spring. These generally departed again for Rohallion immediately after the breeding season. This change of residence has been noted by various Scandinavian and Russian writers, and I have observed that like movements of the roe-deer it nearly always takes place from an old growth of forest to a young one. The females, especially the young ones, are always the pioneers of these movements, ${ }^{1}$ and from close inquiries $I$ am led to believe that many of these young hens fly to considerable distances after mating with the males, and then make their nests and bring up their families in new localities. This is proved by the finding of nests and broods far from the usual Capercaillie haunts, and where no males have ever been seen. In cases where these females have wandered far afield and have not been impregnated, we often hear of blackgame and Capercaillie hybrids, due to the mating of the last-named female with males of the other species. Mr. Harvie-Brown states (p. 198) that he has noticed that the birds thrive best in sloping woods that have a southerly exposure, but I have not observed this. Most of the Earnside woods frequented by Capercaillie have such an aspect, but this is not the case in the Tay valley and Forfarshire, where the birds are equally numerous. On the whole, I am inclined to think that the main winter resorts are the high fir woods of the upper slopes, whilst the nesting grounds are more often the younger forests of the river valleys; but there is no hard-and-fast line, except that females always outnumber the males by ten to one in the younger coverts of deciduous trees.

In the autumn it is not unusual to surprise both males and females at considerable distances from woods, and I have seen many killed when rising out of deep heather at some distance from the timber. Owing to the preservation still wisely enforced by Lord Breadalbane upon his shooting tenants along Loch Tayside, Capercaillie are becoming numerous in the birch woods on both sides of the loch, and are often found in such semi-open ground as is frequented by black grouse. Their numbers in this locality received a welcome addition during the great gale of 1895 , when half the fir forests in this part of Scotland were blown down. A keeper at Achmore, Killin, where there was an isolated wood full of Capercaillie, told me that at the end of the gale there was only one old Scotch fir left standing, and upon it he counted over forty

1 Lloyd, an excellent authority on Capercaillie in Norway and Sweden, considers the males to be more abundant than the females, and the author of Tidskrift for Jagare states that this is the case both in this species and blackgame. He also remarks that it is the males which give rise to the big migrations in Scandinavia. It is quite possible that he is correct, for in three visits to Norway I have seen quite as many males as females of both species, whilst in Scotland the reverse is undoubtedly the case. 


\section{The Capercaillie}

birds the morning after the storm. These Capercaillie migrated eastivards to the woods on Loch Tay.

"The inevitable law," says Harvie-Brown (p. I Io), "exists that there is a distinct limit to the population of a species in any one locality, regulated by the size, capabilities, and amenities of the area, and when the limit is reached and exceeded the surplus population is forced to seek new ground. Further, as the internal pressure continues and increases, the greater difficulties will be faced and surmounted by the pioneers, in order to fulfil the destiny of the species, and the amount of success achieved will depend upon the hardihood and 'fitness' of the species in the struggle for existence.

"The easiest and most natural courses of advance followed the valleys, up or down stream, or stretch along the wooded foothills and slopes, preferring, as already pointed out, the sunny expanses. This is clearly illustrated by the past, that Capercaillie, in a comparatively short space of time, reach and populate more remote localities in the directions whence the great valleys lead them, than they do in those directions where mountainous or treeless country intervenes."

No doubt Mr. Harvie-Brown is correct that they do not cross mountain ranges unless they can view forest-covered country beyond, but I am convinced that they have on many occasions found their way to isolated covers, especially in Forfar, Fife, \&c., to which they must have gone from great distances beyond the reach of vision. As previously stated, I saw a cock flying across the Firth of Tay, and nearing the coast at Tents Muir. It probably came from the Carnoustie woods, the nearest point on the north side, and a distance of about ten miles. Three miles further on it would reach the long isolated fir wood on Tents Muir, where there always has been a few Capers ever since I can remember. At the present time Capercaillie are most abundant in the following districts and places: the Tay valley, from Taymouth to Perth, and in all adjoining woods; the valley of the Earn, from below Perth to Crieff; Strathmore and about Fotheringham in Forfarshire; Sauchie (Stirlingshire), and Arran.

The largest number of Capercaillie ever killed in one day was at Fotheringham, in November 1894. The birds had been increasing for some years, and it was considered that they were doing damage to the crops, so a battue was organised by $\mathrm{Mr}$. Walter Fotheringham, and Io7 birds fell to the guns. James Keay, our old keeper at Murthly, was present, and told me he had never seen so many Capercaillie in one day. The largest number killed in Perthshire was at Fowlis Wester, Earnside, in November I 890 , when 40 were bagged. I shot there the following year at the Caper shoot, and we only got Io, the keeper saying that the birds had almost deserted the big wood since the previous year. I have been one of the guns when the following bags of Capercaillie have been made between $188_{3}-1898$ : Ladywell (Dunkeld), 35 cocks; Logierait, 33; Dupplin, 28, 27; Murthly, 28, 25, 22, 21, 20, 18, \&cc.; Rohallion, 18 (12 cocks). In adjoining estates numbers less than 12 are often killed. No doubt a larger bag of Capercaillie could be killed at Taymouth than in any other northern estate, but the present Marquis of Breadalbane kills very few of the birds, as he likes to see them flying about. Neither does he allow his tenants to shoot them. In 1862 it was estimated that there were at least 1000 to 2000 birds on the Taymouth estates, but I think this was an over-estimate. When we rented the Murthly shooting on which there are 


\section{The Natural History of British Game Birds}

3000 acres of larch and fir woods, the Capercaillie had been overshot. During the first years we seldom killed more than 50, and I gradually increased the stock of hens till we left in 1892, when the usual bag was about 150 . Other places where Capercaillie are numerous are Dunkeld, Logierait, Ballinluig, Dalguise, Methven, Ochtertyre, Monzie, Tulliallan, and Easter Ogle (Forfarshire).

As a rule the Capercaillie is found seated high up in a larch or Scotch fir. It has excellent power of hearing, and generally takes alarm in open woods before the gunner or driver comes within shot. Then it launches itself into the air, much after the manner of the cormorant, dropping several feet before flapping its large wings. In thick cover it makes a loud flapping noise as it clears the surrounding branches, and is then perfectly silent. The flight is rapid, easy, and "swinging." It makes several swift beats of the wings, and then "sails" for a considerable distance; whilst passing over and through trees it is constantly swaying from side to side to avoid obstacles. In this respect of swift guidance it is the superior of any of the Gallina, and its movements are so easy, noiseless, and rapid, that many a shooter new to the sport fails to detect the large birds as they pass him. I introduced my friend, Mr. George Lodge, the artist, to Capercaillie shooting at Stobhall, and the first bird he killed he mistook for a woodcock until he picked it up. The rapidity of flight is about equal to red and black grouse. I have frequently seen all these species in the air at once coming to the guns, and there appeared to be no difference in speed, although the Capercaillie were doing nothing but "sail." This steady gliding movement is deceitful. I once put my old friend, Archie Wortley, a first-class shot, in a place where I knew he would obtain an old cock, if there was one about. He obtained three chances and missed all, entirely misjudging, as he confessed, the pace. Once he had killed one, however, he was a fine performer, and we had many happy days together in the Perthshire forests.

Capercaillie, when travelling from the low to the high grounds, generally find it necessary to make one or two little circles in the air before leaving the wood. This is performed in order to find the necessary elevation for the point of final rest, so that no great effort may be made during flight. They do not seem able to fly uphill except on slight gradients. It is a pretty sight to observe one preparing to start on a long journey. Once I saw a hen leave a high hill above the Stenton cliffs. After several preliminary circles she rested on the tree again, and then rising again in widening circles she attained an elevation of at least roo feet above the trees, and then made her point towards Craigie Barns, a lofty hill above Dunkeld, about five miles away. Coming suddenly to the end of wood, a Capercaillie will often "shoot" uphill for a considerable distance, being borne forward by the impetus of flight, just as a peregrine "lifts" after a "stoop." Then it nearly always returns to the wood and alights. On still days it makes a slight noise, as of a duck passing overhead, with the beats of its wings. The hen bird rises neatly from the ground on hillsides, but makes almost as much noise as the cock when breaking out of cover. In flight the feet are drawn up close to the body as soon as the bird is fairly launched into the air. When about to fly their actions are deliberate and performed without fuss, even when suddenly surprised. 
During gales they spend much time on the wing, flying from wood to wood. Falling trees or thunderstorms seem to render them nervous for many days.

Capercaillie alight much like black grouse, but make a slight flapping in the final movement. They stand erect for a few moments and then walk sedately away, or run swiftly into the nearest bushes. I have never seen them squat at once, as black and red grouse frequently do. The males walk and run more erectly, and are not nearly so swift in their movements as the females. It takes an active young man to catch a running hen Caper. I saw a female Capercaillie by the roadside in Norway in 1907, and ran after her at once, but she outstripped me and rose out of shot.

The food consists of a great variety of fruit, cereals, vegetable, and insects. In the autumn they are very fond of repairing to fields where the grain has been cut, and sitting on the stooks, make a meal of oats, much after the manner of grouse or blackgame. In August, too, their principal food is blueberries and raspberries, and a thicket of the latter is a sure find for females and young at this season, when of course they should not be killed. In September I have seen them in the turnip fields, but this is rare; and out on the heather, which I think they must eat occasionally. In sunmer the females and young are as fond of an ant's nest as any pheasant, and they will also eat the young shoots of bracken. Grass and a great variety of plant life and seeds also form their menu. They also eat quantities of Indian corn put down for pheasants, for which reason a senseless antagonism to these noble birds has grown up amongst lazy and unobservant gamekeepers. Doubtless the hens of both species quarrel a little at the feeding-boxes, and the lesser birds get hurt sometimes, but the results in damage to pheasants are too trifling to be worthy of notice. Hen pheasants, too, often lay their eggs in the nests of female Capercaillie, and the latter are blamed for disturbing the former.

It is not until the month of October that Capercaillie may be said to take to the trees for food. I have never seen them eat anything from the end of October till April but the shoots of the Scotch fir. Several times I have heard the noise made by a covey of Capercaillie feeding on a frosty winter's day, and have crept up to within a few yards of the party and observed their actions. The females alone make any sound, uttering a low "coq-coq" as they step along the branches and reach for the points, which they nip off smartly with a jerk of the head. Often they partly overbalance themselves in reaching for a choice morsel, and their flapping wings can be heard at some distance. Every few minutes the whole party becomes petrified, as it were, into rigid silence. All stand erect to look and listen. This is the moment when the slightest motion or sound will attract their attention and cause an immediate dispersal.

The winter diet is principally of the leaves, buds, and shoots of the Scotch fir. Mr. M. Dunn (The Capercaillie in Scotland, p. 132) says the crop of a male he examined in November 1873 contained " 203 points of shoots of Scots fir, with the leading buds entire ... II pieces of young wood $1 \frac{1}{2}$ to $2 \frac{1}{2}$ inches long, having leaves attached, but no terminal buds, and 52 buds-making in all 266 shoots and buds, besides a large handful of single leaves of the Scots fir, which the bird had devoured at one meal." In the crop of one examined in April 1874, he found the contents to be "wholly the young shoots, leaves, and buds of larch," counting the number at 918 buds in the crops, besides the bits of shoots and leaves, which formed by far the bulkiest part of the whole. A 


\section{The Natural History of British Game Birds}

friend of mine who was sent out at Murthly to shoot some woodcock, on August ist, came across a brood of Capercaillie. Never having seen such birds before, he killed the old hen and two of the young ones. I examined the crops of these, and found them full of raspberries and the larvæ of certain beetles, whose identity I did not at the time determine.

During midwinter the species seems to be more gregarious than at any other season. In beating woods at this season I have noticed that most of the birds are found within a small area, which seems to prove that after feeding together they do not wander far apart. In early autumn single cocks may often be surprised lying in some fern bank or deep heather, and startle the intruder by their loud flapping and sudden appearance. After very heavy rain, too, in early autumn, I have seen cock Capercaillie almost unable to rise from the ground, owing to their soaked plumage and weak primaries.

At the beginning of April the male Capercaillie resorts to some favourite tree, generally an old broken Scotch fir, and indulges in his display, or "spel," as it is called on the Continent. If undisturbed, the males will come year after year to the same tree to display their attractions before the admiring females. The cock-bird generally flies to his "show" place just as dawn is breaking, and at once begins to show off. The call is described by Howard Saunders, and copied by nearly every recent writer, as "peller, peller, peller," but the author, usually so careful, is much at fault, and one wonders where he obtained his onomatopoic description; for it is not the least like the cry. When in the act of the display the male stretches out the neck, spreads the tail, and lowers the wings, and utters a note something like the words "klick-kleck," repeated with intervals. It then turns the head upwards and backwards, uttering a variety of extraordinary noises or squalls, more like two cats fighting at a distance than anything else. During the performance of the culmination of his display, the bird seems to be thrown into a kind of ecstasy of excitement, and to be quite oblivious to all sounds or movements in its immediate neighbourhood. Soon after dawn the hens arrive, and run about in some excitement on the open sward near the foot of the "spel" tree.

I have been told by James Keay and James Boath, men who had spent their lives amongst Capercaillie, that the male at this season utters a hoarse croaking note to attract the females, but I have not heard it. Neither have I seen the males fight seriously, though I have seen an old cock drive off two evidently younger birds from a grassy wood-edge at Rohallion, regularly used as a "lek." The late James Keay has, however, seen regular battles between them. He has seen two pairs fighting at once, and then after skirmishing, striking, and tearing at each other with their bills, has witnessed the contest develop into a general mêlée of utter savagery devoid of skill. A male would catch hold of the neck of another and drag it about, shaking with fury. On both the occasions on which the keeper saw the contest to a finish, all the combatants were exhausted and incapable of further mischief. Moreover he caught one of the cocks, which was blinded with the blood pouring from its comb over the eyes. Keay and Boath have found males dead in spring as a result of these fierce battles; whilst MacIntosh, the Duke of Athole's keeper at Dunkeld, has told me that he picks up two 


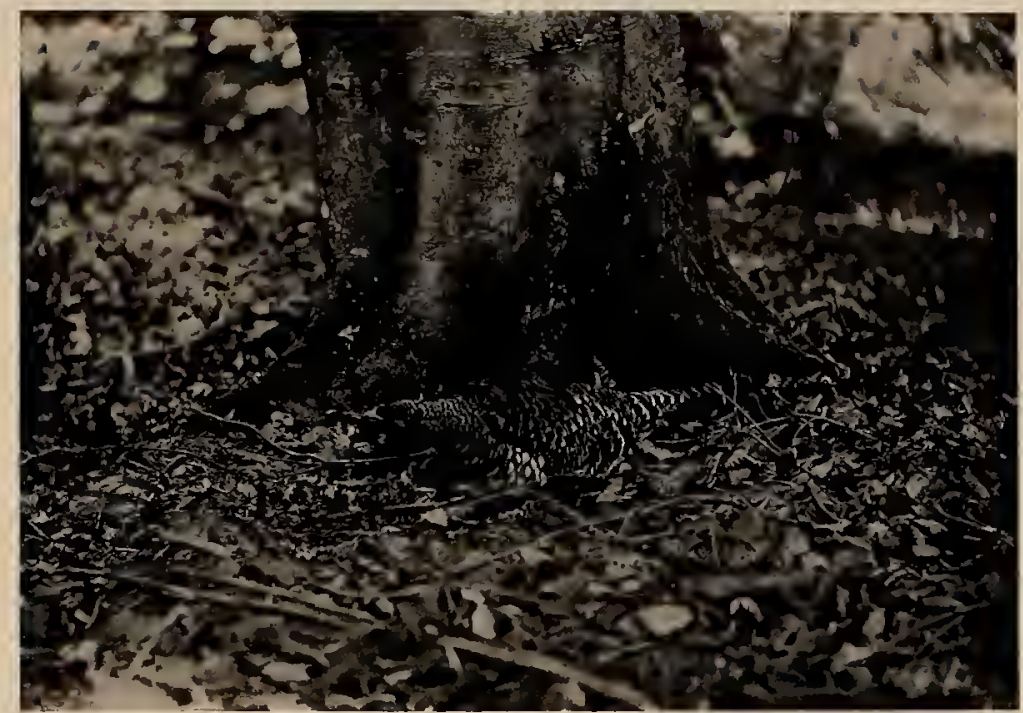

FEMALE CAPERCAILLIE ON THE NEST

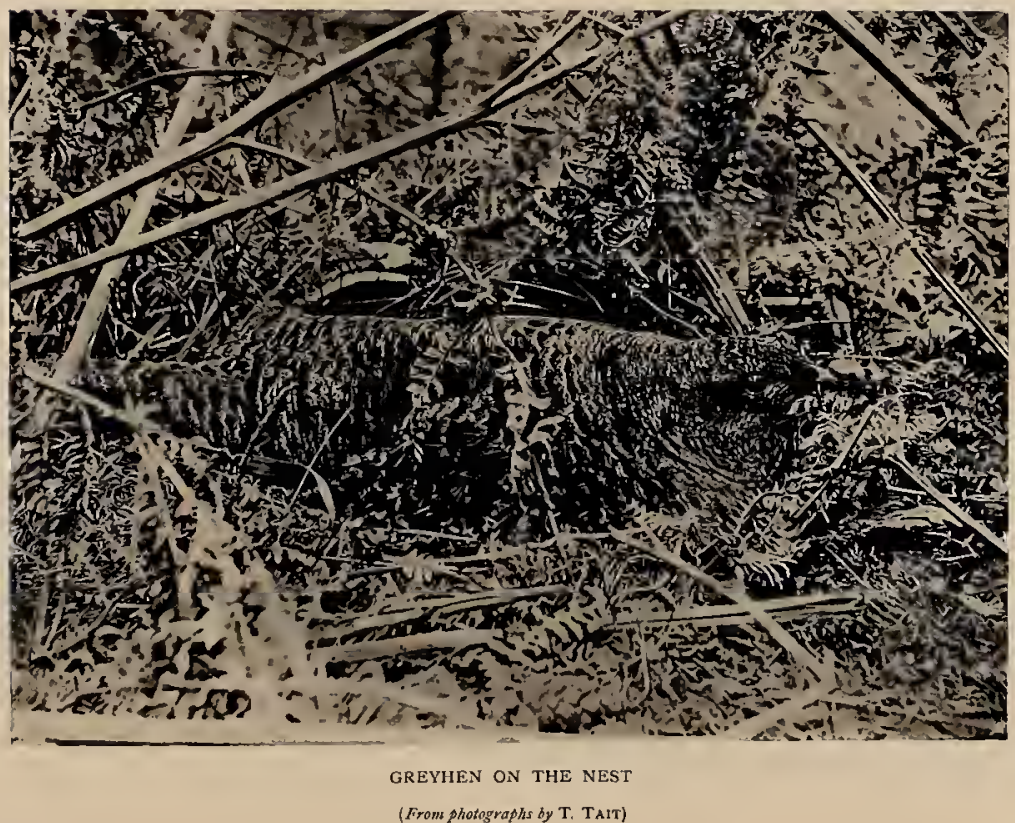



or three dead gladiators every spring. On one occasion Keay came upon two large cocks who had so successfully mauled each other as to be perfectly helpless. They lay facing each other with bloodshot eyes and open beaks.

Shortly after writing Game Birds and Shooting Sketches, I felt that my knowledge of Capercaillie was very incomplete without witnessing the birds at the "lek" and trying to kill one by stalking, after the continental fashion. So one April morning I went to Murthly, and was told by Keay that he knew of a tree in the Big Wood there, where an old male was showing off. I spent the night at his cottage, and in darkness next morning we made our way through the forest. There was a slight paleness in the east when we heard the repeated cry of the Capercaillie cock, who was already uttering his "love-song," and advanced cautiously, being careful not to tread on any stick or brush against the branches of trees. We had arrived within 150 yards of the bird before I saw it, perched on the top of a withered Scotch fir. It was looking about intently, with its long neck stretched in a position of alarm. I thought it had seen us, but almost immediately it dropped the wings, threw out its neck, and began to call. I found that the description I had been given of being able to advance only three steps at a time during the final ecstasy was absolutely correct. I dare not take one more, as the bird was again erect and on the look-out. It was very exciting, but on the soft mossy ground I found no difficulty in getting within 30 yards, when an ounce of No. 4 shot completed the tragedy. Next day I stalked another cock, and not wishing to shoot it, tried to see how near I could get; the approach being made to within 20 yards. Three days later, with James Boath, I stalked a cock on the high ground at Rohallion. Here I found the ground less in my favour, and it was only after considerable difficulty that I got within 40 yards of the bird, sitting on the high wall of the Buffalo park.

In discussing the comparative ease of getting within shot of Scotch Capercaillie with my friend, Mr. Neville Henderson, who has shot many of these birds at the "lek" in Russia, he pointed out that the nature of the ground over which the stalker passes is the principal difficulty of making the approach. In Russia the ground of the forest is full of pools and marsh, or covered with noisy débris, whilst the woods are more open, the trees larger and greater conductors of sound. He agrees that even the wildest Capercaillie, and they are very shy in that continent, are quite unaware of external circumstances during the moments of passion when the three forward steps are made.

Prince Fürstenberg, who has stalked the cock Capercaillie regularly for many years, tells me that it frequently selects a spot on the ground or high rock on which to make its early morning display. In excess of excitement it will leap several feet in the air, flapping its wings, and uttering the preliminary call. He mentions also an interesting habit of the bird which does not seem to be known, namely, that it returns every evening for a short period to the "lek" tree or spot, but does not go through the same performance as the morning, but stands erect, looking about, and utters three notes, "ack-ack-eeack," as if about to be sick. All the time it maintains an attitude of vigilance, and has no moments of ecstasy, so that stalking is not possible. Austrian sportsmen think that we are most unsportsmanlike in shooting female Capercaillie, which they do not do, and we in turn fail to see the interest in potting a large bird sitting at 35 yards. But critics in any particular sport have no right to criticise that 
which they do not understand, for we find on trial that many things voted slow or unfair are in reality quite the reverse, while much that is called "sportsmanlike" does not deserve the title.

Prince Fürstenberg kindly sends me the following interesting notes of the calls and habits of Capercaillie at the mating season:-

"Capercaillie select special spots where the birds of both sexes collect during the pairing season in spring (April and May). The number of cocks and hens at these places varies considerably. There may be only one cock, which as a rule is an old one, and several hens; but I have also seen as many as thirty cocks crammed together within a space of less than half a mile in diameter, and the same number of hens, or even more. The cocks arrive at the pairing places any time after sunset, and before it gets quite dark, either flying or on foot. I have often seen them walking about, and feeding before they take to the trees.

"They make a peculiar noise in the evening, which is quite different from the pairing song. We call it 'worgen' in German, and it reminds me of somebody being sick more than anything else. I should have rather not used this unsavoury comparison, but cannot think of a better one. The noise consists of three syllables, and sounds something like cha-cho-khool ... repeated over and over again, sometimes after all the other birds have gone to rest, and no other sounds except the cry of the brown owl are heard. Then the cock also goes to sleep on a big branch of his tree, and usually sits close to the trunk.

"As soon as the first signs of early dawn appear on the eastern sky the cock wakes up, and begins his early song. It consists of three different successive tunes. The beginning of the first one sounds like the knocking together of two little sticks in intervals of ten to fifteen seconds (like this : klick-kléck; interval, klick-kléck; interval, klick-kléck . . .), getting quicker and quicker, and sounding towards the end more like the ringing of a bell, and ending with tune No. 2, which merely consists in a sound comparable to the uncorking of a bottle. After that he finishes up with tune No. 3, sounding like the twittering of a bird or the grinding of a knife (like this: sch-scht-ssts-pss-sch-scht... and so on). Whereas No. 3 is not audible very far, No. I, and especially No. 2, can be heard at a long distance (over half a mile on a calm night). When the cock does No. 3, he can be approached easily as he nearly is deaf. He does not often sing for more than half-an-hour in the morning, sometimes remaining the whole time on his tree, sometimes going on another one, but usually comes down to the ground and continues his song there, jumping a distance of ten or twelve yards at every No. 2.

"The pairing song of the cock is, however, not confined to the morning. I have on various occasions heard them sing, and shot them in the evening, especially in the Black Forest, whereas this is quite an exception in Bohemia."

Although I have spent so much time in Capercaillie haunts in the autumn, I have never heard the males make any sound at this season, nor have I received a satisfactory answer that the male ever calls during October from keepers and others whose lives are spent in our northern woods. Nevertheless it seemed to me most improbable that the cock Capercaillie had no pseudo-erotic show or calls in the fine days of autumn, accordingly I addressed a line to Prince Fürstenberg on this point, and received the following reply:-

"It is not an uncommon occurrence for the Capercaillie cock to sing in autumn. I have on various occasions heard him make his love-song in September or October-just the same as he does in spring. I remember one evening in Bohemia-I believe it was the 12 th of October -to have found a cock singing, and to have approached him within a few yards. Then, again, in the Alps one evening, on the 7 th of October, high up near timber line. And two years ago, 


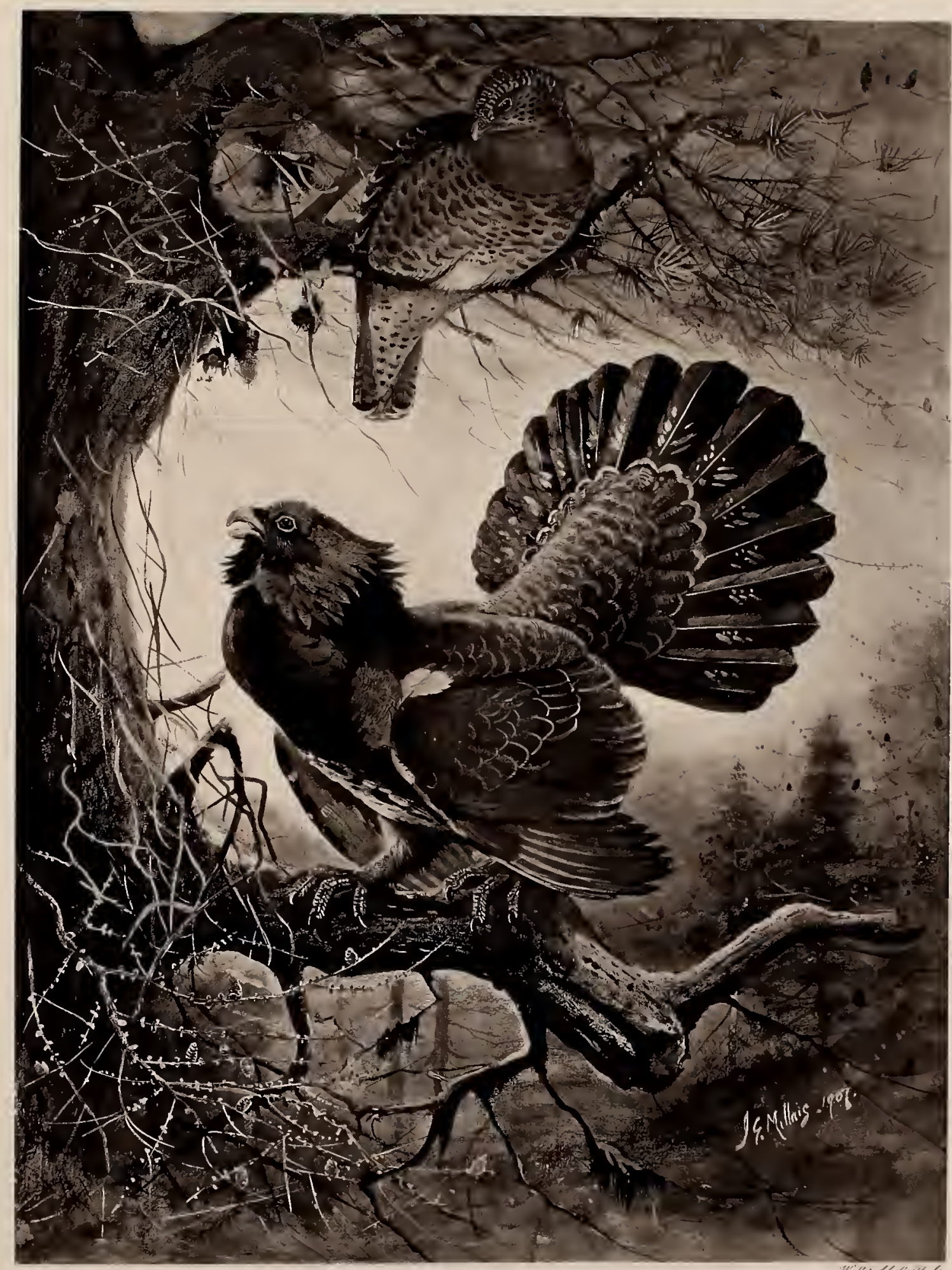



on the $27^{\text {th }}$ of September, in the Carpathian Mountains in Hungary. It was before daybreak, I was listening to a stag calling, when a cock began to sing quite close to me-on one of the pairing places, where there are eight or ten as a rule in spring-and went on as if it had been April. The gamekeepers in these different localities which I mentioned do not consider it a very rare thing to hear the cock in autumn, especially on a fine night. It may by the way interest you to hear that I don't know of anybody having shot more Capercaillie than my late father in Austria and Germany. He killed over I 100 in his lifetime, and sometimes bagged as many as fifty to sixty in one spring pairing season-six in one night being the record."

The usual nesting month of the Capercaillie is May, but on high ground the eggs are often not laid until June. The site generally chosen by the female is the foot of an old Scotch fir or larch, or the sheltered side of an uprooted tree. The shadow of a sloping pine is also a favourite position. I have also șeen nests in deep heather and in clumps of raspberry bushes, but this is unusual. As a rule, no attempt at a nest is made. A hollow is scraped and lined with pine needles; sometimes a few feathers and a little moss is added to the sides with surrounding sticks worked into a slight barricade; but if there are no twigs the bird seldom carries any to her nest. At first the female covers the eggs with pine needles on leaving the nest, but neglects this precaution as soon as incubation commences. The eggs are somewhat similar to those of the greyhen, only much larger. They are 2.2 by 1.5 in size; the ground colour, of a light reddish brown, is thickly spotted and blotched with dark reddishbrown markings. From six to eight is the usual number, but ten is not infrequent, whilst I have heard of twelve. Incubation lasts about thirty days. The hen bird sits fairly close-that is to say, she will permit an interview at 12 feet. If the intruder approaches nearer she will rise with much flapping, and perhaps break some of the eggs, some of which are often flung from the nest. It is therefore very unwise to disturb a hen bird on the nest, and the claims of the photographer are the only excuse. It is curious to notice on viewing a nest where Capercaillie have recently been hatched that the egg-shells are broken exactly in the centre, one-half being placed inside the other. This could hardly take place accidentally, and Mr. Seton Gordon thinks it is done by the parent bird. The nest of the Capercaillie is most conspicuous when the hen bird is absent, and she has failed to cover her eggs as she often does. In consequence, large numbers of nests are destroyed annually by vermin, especially by hooded crows. Both pheasants and greyhens occasionally lay their eggs in the nests of Capercaillie. I have known of three cases, all in Perthshire, where female Capercaillie have made nests in trees 10 to 15 feet above the ground, and have successfully hatched out broods. Nests are often made close to keepers' houses, or roadsides, and Prince Henry of Liechtenstein informs me that a female Capercaillie made a nest in 1907 within 5 yards of the rear of a dog-kennel (where the dog was always chained up), and only a few yards distant from a forester's hut. In spite of the disturbance of the dog, she hatched off her eggs. Young Capercaillie are very delicate in their early stages, and many succumb to late frosts and heavy rains. Moreover, the mothers are not, I think, so careful with their offspring as grouse are. From the first the young are very active little creatures, and run swiftly. The hen bird is very courageous if her brood are suddenly menaced, more so than any gallinaceous bird I know of, except ptarmigan in unfrequented places. 


\section{The Natural History of British Game Birds}

She will rush at an intruder with lowered wings, spread tail, and bristling hackle and open mouth. They will often strike a man with beak and wings if he stoops to touch one of the chicks. I have reared red grouse, black grouse, and Capercaillie, and have found the two last named equally difficult to bring up. They have a way of dying suddenly, when half-grown, from no apparent cause.

Mr. W. H. St. Quentin, who is one of the most successful aviculturalists in these islands, has very kindly sent me the following notes on his unsuccessful attempts to rear young Capercaillie :-

"I have found them more difficult, by far, than any other 'game-bird' to rear, and there is something which evidently we fail to supply to the chicks, apparently when they are about quail size, say, one month old, which is essential. It is not merely a question of ground (elevation), or soil, or climate. Two clever Scotch keepers have tried repeatedly to rear Capercaillie for me. In one case a Norfolk man, most successful with pheasants, grouse, and tame partridges, and with Capers on his present beat in Kincardineshire, did rear me two birds. These proved both to be hens, and it is interesting to notice that they both nested and sat here the following summer. This, of course, with no result, as there was no male bird with them. But it proved that Capercaillie hens breed in their second summer (when a year old).

"In the other case, another keeper, whose house is on the edge of a wood where Capercaillie breed, made a large enclosure, and turned out in it a quiet hen with a brood of newly hatched chicks. The ground seemed quite suitable, being broken with hillocks and hollows, on gritty soil, and with all the moorland plants growing under old Scots firs. No young bird was reared in this case, though I am sure the keeper would do his best.

"I have tried here more than once to rear Capers from eggs sent down from Perthshire. The young have never got beyond partridge size, though up to that time they have thriven. They generally fell amiss and died within twenty-four hours.

"I reared two young hens, three years ago, from eggs laid here by a pinioned (German) bird. But my nearest approach to a real success was in 1907, when, as I recorded in the Avicultural Magazine, we had six young birds thriving till the beginning of August, when the cocks were just beginning to show colour on their shoulders and mantles. These birds were reared, till they were a month old, entirely in a dry shed facing south, on sandy soil, kept most scrupulously clean, and frequently attended. These were from the second clutch of a very nice tame hen. Her first brood hatched well, and at first throve, but I think they died of pneumonia, and I decided for the second brood to protect them from all chance of damp. This was successful, and I have no doubt that we should have reared these birds completely, but for a most unfortunate accident. I had a couple of Cabot's Tragopans in London, and sent them down home. One of them died in an aviary, and the illness was not at this time recognised. It turned out to be undoubtedly septic enteritis, for during a violent thunderstorm these six young Capercaillie were driven into this aviary for shelter from their enclosure, where they had been rumning about loose, mothered by an excellent little silky game bantam hen. They were only here for a few hours, but it was enough. Nine days later first one and then another sickened and died, and in the end I lost them all. Several of them were examined by a specialist. The Caper chicks thrive upon custard, chopped lettuce, live ants, eggs, earthworms, oatmeal groats, canary seed, and they soon peck and pull at clover and grass. Good grit and absolutely pure water are of course essential. If I try any more, which I hope to do, I shall increase the animal food, say, with chopped boiled rabbit, especially as these birds grow older. I may say that I reared Temminck's Tragopans and Red Grouse under precisely the same treatment with which, this summer, we failed with Capercaillie. They were all running loose with their own foster-mothers, in an enclosure of an acre of perfectly clean ground, where no birds had ever been kept or reared. I am sure damp is their chief enemy, and I think that the chicks may want more animal food as they grow up and feather. 


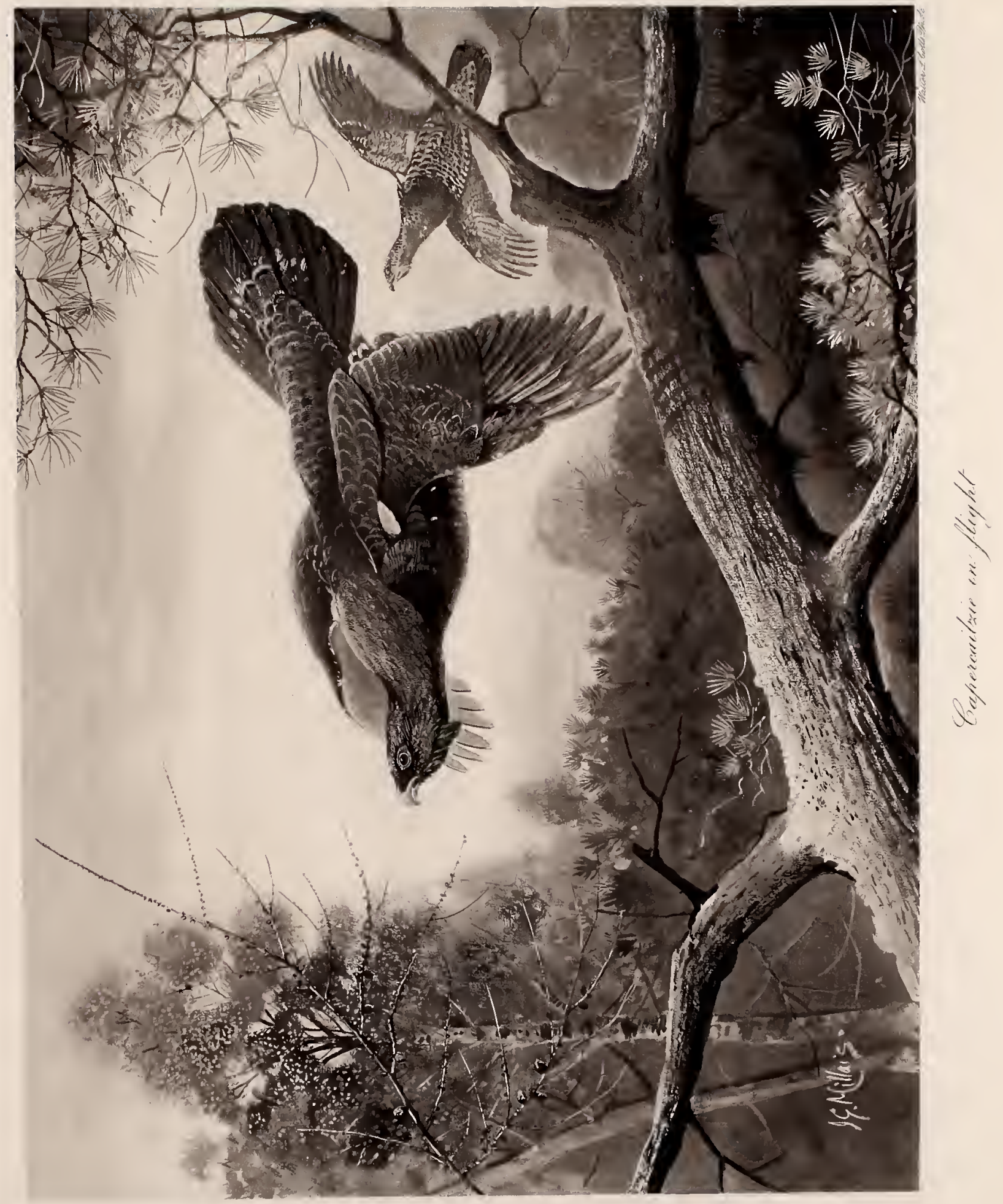





\section{The Capercaillie}

"I have kept wild caught Capercaillie (German) for four or five years. The first male I ever kept became quite tame, but he was shy and timid for the first three years. My hen Capercaillie that nested here repeatedly made beautiful nests in quite typical positions, against the stem of a birch generally, or in one instance on very bare ground under a fine beech tree, quite out in the open.

"In confinement, beside pine branches (Scots or Austrian) my birds in winter have plenty of mangold-wurzel roots. Capercaillie, Impeyan Pheasants, Blackgame, Grouse, Tragopans, true pheasants, \&c., are all very fond of these, but they must not get frozen. These birds want plenty of room, and lots of cover to hide in."

Young Capercaillie, of which seldom more than five survive the difficulties and dangers of early life in the northern woods, grow very slowly. By the i2th of August they are still small and only just commencing to exhibit the feathers of maturity. In September they gradually stray away from the mother, and are fit to shift for themselves.

Capercaillie, if undisturbed, are fond of roosting in the same trees night after night. These are easily recognised by the numerous droppings.

There is no doubt that Capercaillie are destructive to forests, and especially to young plantations of fir and larch. When the birds were newcomers to certain high land estates they were cherished as welcome additions to the fauna, but now it is common to find intense and often unreasoning animosity displayed towards these noble birds by proprietors. There are many estates in Perthshire where roe-deer and Capercaillie are shot on sight at all seasons, and the nests of the birds stamped upon. This, I think, is unjust. Kept within reasonable limits, the birds do very little harm to forests of twenty years and upwards. Moreover, it is quite possible that they may do good by destroying insects injurious to some trees. Young Capercaillie feed largely on larvæ and insects, and Herr Dr. Meves of Stockholm expressly states that the young which he found in Jemtland had their crops full of Tenthredo or Nemitus larvæ, insects most injurious to pine trees.

Capercaillie seldom visit very young plantations of fir and larch where there are no roosting trees, and damage to top shoots-a misfortune that will destroy the shape of any tree-is more likely to be caused by blackgame, which are fond of breaking off the leader. Then, again, there is the beetle, which attacks the leading shoot of Scots fir and larch, and which does much harm. Its work, however, is easily recognised by the fact that it cuts into the base of a shoot, which dies and falls over, whereas a tree attacked by a Capercaillie or black grouse has the shoot or bud bitten clean off. The worst enemy of all to fir and larch is the squirrel, whose favourite food at certain seasons is the shoots of coniferous trees.

No law regulating the shooting of Capercaillie has been passed since their introduction. Consequently they come under the schedule of wild birds, which may be shot at all seasons, from August ist to March Ist. This is unfortunate, as many are killed in August and early September, when the birds are totally unfit to be killed, except for the table. As an object of the sportsman's aim, rising out of heather or bushes, they are contemptible; but the same bird, if allowed to live until November, when it comes rocketing and swaying above the tops of high trees, is an object worthy of the gunner's skill, to say nothing of the delightful variety it makes in the day's bag. Capercaillie are easily kept within limits by driving the woods, and I never met a sportsman who did 
not enjoy a "stand" at Capers. The pleasure of doubling up a "high" cock that comes crashing to the ground is a very real one, and must be experienced to be fully enjoyed. On those pellucid autumn days in October and November, often the best months in the whole year in Scotland, the gunner stands waiting on the steep hillside, with pulses high and nerves alert. He must keep a sharp look-out, for in this sport the ears are useless. A Capercaillie makes none of the scurrying noise of the approaching pheasant, and calls for some knowledge of woodcraft and observation-attributes scarcely necessary nowadays in the pursuit of the meaner bird. If he sees the little brown or black dot approaching, he must not move or his quarry will swing off, up or down the hillside, and escape out of shot, and if the cover is thick, his gun must come to his shoulder as smartly and accurately as is required for a woodcock.

Capercaillie are not nearly so "obstinate" as black grouse when being driven, and do not break back over the beaters to the same extent. A gentle tapping of a few beaters at wide intervals is all that is necessary to "move" them to a desired point. If hit well forward they are easily killed, and I oz. No. 4 shot and 33 grs. Schutze is the charge I have found most effective. Several times I have heard sportsmen state that they have been attacked by wounded cock Capercaillie, but personally I have never seen any proof of active resentment on the part of the bird. When chasing a cock to kill it I have often seen the male lower the wings, spread the tail, open the beak, and erect the hackle of the neck. When captured by the hand they emit a loud hiss, the only sound they ever make, except in the breeding season. One day at Murthly the late Sir William Harcourt assured me that he had been attacked and bitten by a savage cock he had attempted to catch. I was interested, and went to retrieve the fugitive after tying up my dog. The bird in question showed resentment, as I have described, but in no way could I induce it to strike with its wings or to bite the hand I held in front of it.

It has been shown that female Capercaillie are nearly always the pioneers of all movements to new localities, and these arrive in suitable places before the appearance of the males, who by the way are seldom more than a season in following them. In the first year of their arrival these hens often accept coition with the males of other species of suitable size. In areas frequented by black grouse, the hybrids which result from this cross are of such common occurrence that I will not particularise the records. I have seen at least one hundred in Perthshire alone, and have little doubt that as many as fifty have passed through Mr. Malloch's hands in Perth. The first bird seen at Tulliallan in Perthshire, in 1854, and the first seen at Loch Loy in Nairnshire, in I889, were male hybrids of these two species, and many other instances could be cited. Female examples of this hybrid are extremely rare, even on the Continent, and I do not know of a British example. A much rarer hybrid is that between Capercaillie and pheasant, of which I have seen or heard of four examples: the first was killed at Arden, Loch Lomond, in I888, and was figured by me in Game Birds and Shooting Sketches; the second was killed in 1891 by Sir Arthur Grant at Monymusk; a third was killed at Stronchullin, Blairmore, Argyllshire, in September 1897; and a fourth has occurred of which I have lost the particulars. All these hybrids were males and very ungainly looking birds, without the beauty of either parent. 
Females assuming the whole or partial dress of the male are not by any means uncommon. Mr. Harvie-Brown cites only four instances known to him up to 1888 , but he has probably seen and heard of many since that date. I have seen quite fifty such abnormal females, and possess three-two of which I shot myself at Murthly. One of these was in the perfect dress of the other sex and looked like a dwarf male. I believe that one of these barren females assuming the male dress is found in every two or three hundred specimens that are killed; so that the variety is commoner in this species than in any of our gallinaceous birds.

Albinistic varieties of the Capercaillie are very rare in this country. I have only seen two Scotch examples-namely, a cream-coloured female shot by Mr. Malloch at Fowlis Wester in I89I, and now in the possession of Mr. Turner, and a very large adult male, partly white, shot by Colonel Stuart Richardson at Ballathie in November I889. This bird lived at Murthly for some time, and I tried hard to shoot it, but never obtained a chance. It disappeared for two seasons, and when Colonel Richardson killed it he kindly sent it to me. A figure of this bird appears in Game Birds and Shooting Sketches, p. 47.

These albinistic varieties are not very rare in Scandinavia and Russia. There are many beautiful examples in the museums of Lund, Stockholm, Bergen, Christiania, and St. Petersburg. The Hon. Walter Rothschild also possesses some notable examples in his magnificent collection. 


\title{
Genus : Lyrurus
}

Characters.-Feet feathered, and pectinated at the sides. Tail consists of eighteen feathers, the outer pairs being curved outwards at the extremity. Only two species are recognised in this genus-namely, the Common Black Grouse of northern Europe and Asia, and the Caucasian Black Grouse, Lyrurus mlokosievviczi, whose habitat is confined to the Caucasian Range.

\section{THE BLACK GROUSE}

\author{
Lyrurus tetrix, Linnæus
}

LoCal Names.-Black Game, Blackcock (male), Greyhen (female); Heathcock, Heathpoult (Devon and Sonerset); Grugiar Ddu (Black heather hen), Ceiliog Du (Blackcock), Ceiliog y Mynydd (Cock of the mountain), Ceiliog y Rhos (Heathcock) (Welsh); Coilleach dubh (Blackcock), Lia-chearc, Cearclia (Greyhen), Cearc fhraoich (Hen of the heather) (Gaclic); Coq de bruyère (French); Birkhahn (male), Birkhuhn (female) (German).

Adult Male.-Bill and feet, black; head, neck, nape, mantle, back, and rump, black, with steely-blue margins to the feathers; tail, lyrate in shape, black in colour; breast and belly, black, becoming ribbed with white about the vent; under tail-coverts, white, and in the black form ribbed or pencilled with half-moon crescents of black $;^{1}$ scapulars, lesser and median wing coverts, black, with a brown tinge; bastard wing and secondaries, black, with broad bars of white; primaries, brownish black; the quills and outer edges being a pale brown.

The Blackcock, like the male red grouse, has a very distinct eclipse plumage in late June, July, and August. At this season the bird has an untidy appearance, the whole of the plumage being duller and browner than at other seasons. The lower throat and cheeks are straw-colour, interspersed with black feathers, edged with a narrow margin of white. The crown of the head and whole of the back of the neck is a rich

1 Adult males with black-ribbed under tail-coverts are not uncommon. In some instances, every feather is broadly edged with black. Mr. J. A. Harvie-Brown sends me the following note: "It seems that the young males in the first year have no such markings. The birds showing the most complete $V$-shaped black marks are birds in their prime, and after this they seem to gradually disappear, first from the returning inner edges of the feathers, and then by partial, and finally complete disappearance along the quills, until the under tail-covert feathers of very old birds are spotless. I have not, however, obtained a complete series." I cannot, however, quite agree with this. Certainly young birds are spotless, but I think that adults of the very dark form would retain the black markings until advanced age, though it is likely, as Mr. Harvie-Brown suggests, that in very old birds the markings would be lost. It seems impossible that Mr. Harvic-Brown could tell the age of the birds whose parts he examined. In a further note the writer says: "The very large series I had clearly demonstrated the steady flow and uninterrupted increase of the black pigment along the open ducts, quills, plumules, and filiz until the prime of life. To all appearance all parts of the plumage were reached up to complete development (the only blanks being spring and summer stages). No breaks or spaces occurred whilst the dispersal of the pigment was progressive. IWhere blanks occurred in otherwise continuous markings I looked for other symptoms of decay or retrograding, and satisfied myself that retrograde action had begun." 


\section{The Black Grouse}

brown, barred with a fine line of black, over which is a brown suffusion. The rich scarlet comb, much inflated in spring, is now reduced to normal size. Length, 23 to 25 inches. Wing, Io to I I inches. Weight (young male), 2 lbs. Io oz. to $3 \frac{1}{2} \mathrm{lbs}$. Adult male, 4 to $4 \frac{3}{4}$ lbs.

Adult Female.-The bill and feet, black, but not so dark as those of the male; general colour, rich brown, with all the feathers barred with black; the throat, unlike continental specimens, which are generally grey and barred with black, is pale chestnutbrown, barred, and with a little grey at the lower ends. Breast edged with greyish white, as also vent. The under tail-coverts extend beyond the tail, and are white faintly barred with brown, and broadly barred with black; a little grey is usually seen on the edge of the secondary wing coverts. Females are about three inches shorter than the males. Weight, $2 \frac{1}{2}$ to 3 lbs.

Immatures. - The general colour of the young in down is orange-red brown, spotted and blotched with black; the crown of the head is brown. In first plumage they are a fine mixture of brown and grey, with finely pencilled bars of black, the young males being larger, greyer, and darker than the females; the adult plumage begins to appear early in August, and is assumed in October, although dull in tone compared to the full dress, which is not complete until the third year. Young Blackcocks are easily recognised during the first winter by the quantity of brown in the secondaries and crown of the head, as well as the shape of the tail, which is but little curled. I have often seen first-year Blackcock with the breast and cheek feathers finely edged with white. They are also not larger than adult Greyhens.

Distribution.-In the true form, the Black Grouse is found in suitable districts throughout Scandinavia, Russia, East Holland, the hilly parts of Germany and Central Europe, Switzerland (except the Jura), and the Northern Apennines. It is not found in the Pyrenees, whilst in the Caucasus another species takes its place. East of the Urals it ranges up to $67^{\circ} \mathrm{N}$., and south as far as Manchuria. At present we do not know how far to the East it extends. A few Blackgame and capercaillie were sent to British Columbia in 1906, some being released near Vancouver and others on Vancouver Island. The Black Grouse seem to have entirely vanished in 1908, but there was evidence that at least one or two female capercaillie had bred on the Island of Vancouver, near Duncans. In the autumn of I886 Mr. Langrishe-Mare imported about twenty brace of Black Grouse from Scotland into Newfoundland, where they were released between Salmonier and Holyrood. Writing in 1888, Mr. Mare said they had increased "in many parts of his large Island" (Field, Jan. I5, I887), but soon afterwards they seem to have disappeared. At the request of the Newfoundland Government I sent 23 capercaillie ( 8 cocks and I5 hens) and 22 Black Grouse ( 7 cocks and 15 hens) in September 1907 to the island. ${ }^{1}$ They were turned out by Sir Robert Bond between Whitbourne and Colinet, and up to date I have had no satisfactory news of their progress. A close time of ten years has been appointed, but I fear that the Black Grouse may not succeed unless further introductions take place.

In England they are, except in a very few places, such as Staffordshire and the 1 See Field, Oct. 26, 1907. 


\section{0 \\ The Natural History of British Game Birds}

border counties, a disappearing species. On the subject of their recent and present range in England, I have compiled the following summary:-

Comwall.-A few existed till recently on the Bodmin Moors and in the districts of Kilmar and Dosmare Pool. Now almost extinct. (J. Clark, Vict. Hist. Cornwall, vol. i.)

Dorset.-A few may still breed in the county; occasional stragglers come from the east, but nowhere resident except about Chamberlayne's Heath and Hyde Heath, and the heaths between Alderholt and Knighton.

Devonshire.-Scattered in small numbers throughout the moorland districts and resident in Dartmoor on the public parts of the moor, and in the adjoining private estates. Rapidly decreasing in numbers. They are found on the Haldon and Blackdown hills, and on the borders of Exmoor.

There was a considerable stock of Blackgame on Dartmoor twenty years ago, but during recent years, since its discovery by the painter, the novelist, and tourist, the stock of birds has greatly decreased. The chief causes of the decrease are the presence of sheep and ponies, with the chronic disturbance by men and dogs during the nesting season. Moreover, of late years moor-burning has been so carelessly done as to extend right into the haunts of the bird, and at a time the females are nesting. Above Dartmeet was almost a favourite nesting ground. Of recent years as many as fourteen broods have been seen on fifty acres on this ground, ${ }^{1}$ and the late Mr. Robert Torrens always had large numbers of Blackgame on his estate, until Eastertide "swaling" proved too much for him. Recently, too, some of the best grounds for Blackgame were about the prison; now too many gun and game licences are issued, and the small stock of birds is overshot, and unless the Duchy authorities take the matter in hand and do something to preserve what is left, Blackgame will soon be a thing of the past on Dartmoor, except in the preserves of a few private grounds adjoining the public portion of the moor.

Somersetshire.-Formerly plentiful all over the heather and wild regions of Exmoor and adjacent estates. Until 1886 bags of twenty brace and more were often obtained, but now decreasing in numbers. Their favourite resorts are the Quantock and Brendon hills, and the northern skirts of the Mendips, Winsford and Oare. ${ }^{2}$

Surrey.-Until 1888 a few Blackgame were always to be found in the Aldershot, Witley, and Farnborough districts. Those introduced in 1875 to Witley Common helped the old stock for a while, but the species may be said to have become almost extinct by 1900. (J. A. Bucknill, Zool., I9or, p. 253.) According to Mr. G. W. Swanton, two pairs (?) bred in 1905 in "a certain wild tract of country," and a single Greyhen was seen in the spring of 1906 (L. B. Mouritz, t. c. 1907, p. 93). In 1885 I saw a Blackcock and a hansom cab both in view at the same moment near Farnborough. There were one or two Blackgame on the Pudmoors near Godalming and about Frensham Common between 1890 to 1896 .

Bedfordshive.-It is interesting to learn from particulars kindly supplied me by the Duchess of Bedford that the introduction of this species to Woburn, Bedfordshire, has met with considerable success. Experiments began in August 190I, when 


\section{The Black Grouse}

4 cocks and 8 hens were liberated. These were followed by successive importations through September, October, and November in the same year, to the number of 20 cocks and 30 hens. In 1903, I4 Blackcocks and 36 Greyhens were released; in 1904, 5 Blackcocks and Io Greyhens; and in 1907, 6 Blackcocks and I4 Greyhens; making a total of 45 Blackcocks and 98 Greyhens. Recently as many as I6 Blackgame have been seen together, but many have doubtless strayed away, or been killed by foxes. Nevertheless a few nests are found every year, and in one season as many as five are known to have hatched off. All the imported birds come from Hagenbeck.

Sussex.-Blackgame as a resident and breeding species may be said to have become extinct in 1845 , although many isolated females have bred since that date. Mr. Padwick of Horsham has told me that about the year 1840 his father used to kill six brace in a morning at Coombe Bottom, St. Leonard's Forest; he himself has shot many in his youth about Ashfold. Thougl still seen and killed annually about Leith Hill, Crowborough, Hindhead, until 1870, Blackgame have become very rare. I cannot ascertain that any person has shot or seen a specimen in Sussex since 1890. Two attempts at their introduction have failed. In Ashdown Forest they nested until 1862. The late Mr. Howard Saunders in his Manual of British Birds (p. 493) remarks that Blackgame owe their presence in Surrey, Berks, and Sussex to reintroduction early in the nineteenth century; but I think the statement is quite incorrect, and that the species was always indigenous in these southern counties.

Kent.-Extinct, but flourished here in the days of Henry VIII., when it was known as "Grows" (Grouse).

Hants.-Formerly fairly numerous in the New Forest, but now almost extinct. Until recently in the Alice Holt Woods near Farnham, and a few in Wolmer Forest.

Wilts._Occasional stragglers. Formerly in Winterslow and Ellesbourne Woods (Harting); also at Redholm, Vale of Pewsey, and Compton Bassett in 1866.

Norfolk.-Introduction to this county has not met with much success. Mr. H. Dalziel Mackenzie has turned out many Blackgame at Thetford; thirty were imported in 1900-1901. "Broods hatch off regularly, but seem to disappear in some unaccountable manner, and the numbers, in spite of fresh introductions, steadily decrease." (Heatly Noble, British Birds, Sept. 1908, p. I55.) Black Grouse have been seen or introduced at various times at Sandringham, Lynn, Snettisham, and Dorsingham.

Berkshire.-Has been introduced to Windsor and Ascot without success. Occasional stragglers from Surrey.

Shropshive.-Formerly at Whixall Moss and other unreclaimed spaces, now a few only on the Cleehills, Corvedale, Church Stretton, Stiperstones, and Clun Forest districts.

Staffordshire.-Abundant on Cannock Chase, where as many as fifty brace in a day have been killed by one of the Earl of Lichfield's parties recently. A few are still found on the Earl of Crewe's Moors near Macclesfield, and at Swythamley (Leek), where I have shot them, but they are a steadily decreasing species in this part of the county. They are frequently seen about Needwood Forest, Churtley Moss, Cheadle, and Stone.

Leicestershive.-Formerly in Charnwood Forest and Sharpley until 1850 (Harting). 


\section{The Natural History of British Game Birds}

Worcestershire.-Occasionally found about Wyre Forest, also in Bewdley, Cleehills,
and near Eastham.
Northamptonshire.- - Rare visitor.
Herefordshire.-Found at Cusop Hill and the Black Mountains, Bircher Common,
Shobdon, Stoke Edith, and Craswell (Harting).
Northumberland.-It is found at Kielder and all along the North Tyne moors, as well as at Alnwick.

Cumberland.-Bewcastle, Naworth, Netherby, and Crossthwaite.

Westmorland.-Found about Shap, Raegill, and the Lowther woods, \&c.

Durham.-A few about Upper Teesdale, near Stokesley, and Lartington.

Yorkshire.-Still found in small numbers near Sheffield, Huddersfield, and in Wensleydale and Nidderdale. In 1860 Black Grouse were introduced to Birk Brow, Tryup Head, Leverton Moor, and Lartington.

Lancashive.-Found on Winster, Cartmell, and Furness Fells. Introduced at Whitewell in 1864, and Easington Fell in November 1895 (Harting).

Cheshire.-Formerly in Delamere Forest. Seen in 1892 at Broughton.

Derbyshire.-Still found about Strines, Glossop, Hayfield, Castleton, and occasionally on the Buxton Moors, where I have seen them in 1905 and 1906.

Nottinghamshire.-Rare visitors now, but formerly found in Sherwood Forest, Inkersal, Newstead, and Rutcher Hill.

Lincolnshive.-Introduced to Frodingham and at Caistor, I871-72. A few still found in the north of the county.

With regard to Wales the species can only be said to be resident and indigenous in Montgomeryshire, where it exists in small numbers. ${ }^{1} \mathrm{~A}$ few are found in other counties where it has been introduced. It has not been noticed in Anglesey. Pennant in his Tour mentions Black Grouse as existing in small numbers in the Clwyd Range, but a footnote to the I8ro edition states that it was extinct at that date. Black Grouse were once common in Glamorganshire, but are now extinct there. A few are seen occasionally near Trecastle in Breconshire, and on the estates of Lord Tredegar, Lord Glanusk, and Mr. Vaughan Williams.

Scotland is the true home of the Black Grouse in these islands, and they are still fairly numerous in the southern counties, especially about the border. It is not necessary to particularise the districts in South and Central Scotland where the birds are found, for their numbers are constantly fluctuating, according to the amount of protection afforded, skill in management, and improvement or deterioration of the ground which they love to inhabit. One of the best grounds in the south of Scotland is Drumlanrig, in Dumfriesshire. On these moors as many as Ioo Blackcocks have been killed in one day by the Duke of Buccleuch and his friends. They are also plentiful in Wigtownshire and the south-western counties. In Argyll and Buteshire they have left many of the localities where twenty-five years ago they were plentiful, and this is chiefly due to the change in the nature of the forest areas. I know of many places in Perthshire where twenty years ago we used to kill thirty in a day, and now scarcely

1 A detailed description of the present status of the Black Grouse in Wales will be found in Mr. H. Forrest's Funna of North Wales, pp. 307-309. 


\section{The Black Grouse}

a bird can be found. Yet new habitats are favoured by the birds, which formerly were not their home. Taking everything into consideration, Black Grouse are not so plentiful throughout Central Scotland as they used to be, and more hens are spared. But this point I will discuss later. Old inhabitants at Fortrose in the Black Isle have told me that in their youth it was common to see packs of 200 Blackcocks on the stubbles in autumn where now they are scarce. These birds were not shot, but simply left the districts when the woods became too old. In the extreme north, Black Grouse are only common locally in the valleys of Sutherland. In eastern Sutherland they seem to be getting very scarce where once they were numerous, but are certainly increasing in the west along Strath-naver. In Caithness they are also numerous about Berriedale. They are not numerous in north-west Ross-shire, but are found locally all about Gairloch and Loch Carron, also in the wooded parts of Skye. In Mull they are found very frequently, being reinforced by fresh arrivals from the Mainland vid Ardnamurchan, and they have been seen on the Treshnish Islands. They are still plentiful in Islay. Black Grouse have never been known in the Outer Hebrides, although attempts to introduce them are said to have been made; neither are they found in the Orkney and Shetland Isles.

The species has been frequently introduced into Ireland, but without success, and Mr. Barrett Hamilton has given (Irish Nat. 1899, p. 37) details of these attempts in the counties of Limerick, Sligo, Tyrone, and Antrim. Thompson in the Natural History of Ireland and the author of Dr. Pocock's Tour also mention repeated failures in the County of Antrim. ${ }^{1}$

Habits.-The home of Blackgame may be described as the fringe of the moor. On the first heavy snows of winter they retreat to the deep heather found in the birch and rowan area, above the thick timber, and in this sparse cover a few may be found at all seasons. Like the capercaillie, however, they are fond of open spaces or elevated positions, from which a general view may be obtained, and in such positions coveys or packs of Blackcocks may be observed at all seasons except in July and early August, when the males may be said to be like the mallard drakes- "a-hiding." A covey seated on a frosted birch in winter is a beautiful sight, and at this season, unless a close approach is made, it is difficult to tell cocks from hens, but in autumn amongst the rich foliage of the rowans, on whose scarlet berries they love to feed, and which is here so exquisitely rendered by Mr. Thorburn, we notice glorious effects in colour, the browns of the female contrasting vividly with the black and blue of the males in the surrounding foliage. If undisturbed, they are rather sedentary birds, for, except during wild storms, they will stay all day in one spot where food is to be found. Hardly any insect or vegetable food comes amiss to Black Grouse. On examining their crops at different seasons, one is struck by their omnivorous diet. In the summer it is insects, grass points, blueberry shoots, young heather tops. In the autumn, heather, grass and rush seeds, trefoils, sorrel, sedge, grain of all kinds, potato tops, turnips (I have often shot them rising out of turnip fields), blueberries, raspberries, wild strawberries, cranberries, bear-berries, rowan berries, and in winter and spring shoots of larch, Scotch firs, and, most of all, birch buds.

\footnotetext{
1 Bones found in Ballynamintra Cave were assigned to this species by G. Barrett Hamilton, but Mr. Ussher (who found them), in consultation with Professor Nevton, says they are those of grouse.
} 


\section{The Natural History of British Game Birds}

In hard weather large flocks of Blackgame may be observed sitting on the thorn trees, eating the haws, which, like missel thrushes and fieldfares, they do not seem to touch unless the winter is unusually cold. They also eat much birch and alder "tops" at such times. Quantities of sand and gravel are also swallowed to promote digestion.

Although Blackgame show a distinct distaste for districts that are wholly covered with "old" forest, they will resort to the heavy timber for shelter during continuous bad weather, and are often found along the edges of such woods and amongst big trees, especially when there are thickets of gorse and birch amongst them. There was one such place in the middle of the big woods at Murthly, where we always found Black Grouse in winter, but they were seldom to be found there at other seasons. I remember shooting the woods at Guisechan, ${ }^{1}$ in November, when the weather was exceptionally fine, and we did not kill a single Blackcock. In the following year after the first heavy snowstorm the woods were full of Black Grouse, and a number were killed. The ground these birds prefer is rough and broken heather, gorse and marshy lands adjoining open birch forest, intersected by mountain streams. As long as such ground produces the quantity of food, and care is evinced in their management, they will remain, but any change in the nature of their environment causes an immediate or gradual migration to new pastures. In this country we do not observe the wholesale movements so noticeable on the Continent, due in every case to absence or abundance of food; but small local migrations are found to take place all over Scotland, in accordance with local conditions.

The flight is very rapid and enduring. Blackgame are capable of flying great distances when necessity impels them to do so, but when disturbed on their own ground they seldom fly more than a mile. Hardly any sound is noticeable on rising, but on alighting one or two sharp beats make a noise similar to grouse, and in cover to female capercaillie.

In the open they "sail" more than grouse do, and in woods adopt the same swinging movements as capercaillie amongst trees. The flight in cover is usually low, but on open moors a "risen" Blackcock or Greyhen may often be recognised from grouse at a distance by its superior altitude. Another feature in the flight of these birds in the open is the habit they have of circling over ground they have just left or on which they intend to pitch. In this way they often avoid guns at the butts, or with supreme contempt come all down the line, apparently careless of the effects of shot. It is this devil-may-care, bold attitude of Black Grouse that endears them to British sportsmen. You can hardly drive a Blackcock a way he does not intend to go, whilst no amount of firing ahead or flag-wagging behind will turn him from the direction he wishes to follow. I have seen a Blackcock in Staffordshire, after two or three circles over the moor, come over the "butts" and pass away far behind. Then not liking the look of the place, it swung round and came back again over the guns, when it was killed. Such boldness is unusual, but it shows the determined nature of the bird.

I have seen Blackgame flying across the valley of Somerset from the Quantocks to

\footnotetext{
1 Guisechan is one of the best places in Scotland for Woodcock when they first come in. On this day, in a wood of about a quarter of a mile long, we killed twenty-eight. I was the top gun on the moor edge, and killed fifteen to my own gun-one of the pleasantest half.hours I have ever enjoyed.
} 


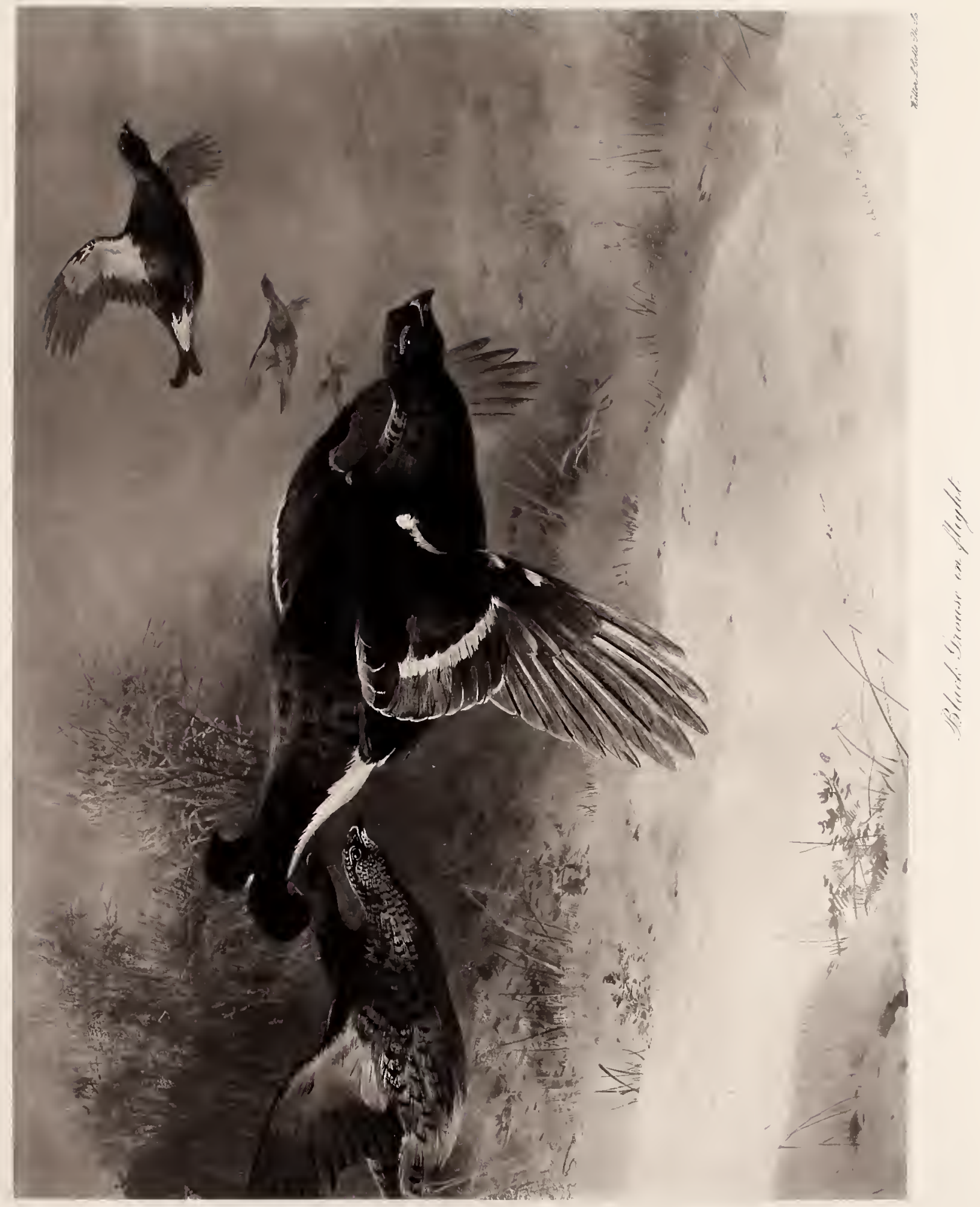




\section{The Black Grouse}

the Blagdon hills, about nine miles, and other places where they were lost to view, but these cannot be called long flights, as in Scandinavia they go for hundreds of miles in a few days. Both capercaillie and Blackgame often resort to a peculiar "header" or dive towards the earth when suddenly viewing men, and in this way often save their lives. I have more than once seen a Blackcock "stoop" from a height to join grouse that have been flushed below, and the speed at which he flies is apt to be deceitful. It is from forty to fifty miles an hour according to the. wind. They have, however, a marked aversion to being "pushed" beyond their regular pace, and in this respect are very different from grouse, which will always take the help of the breeze if they can. This is probably due to the shape and length of the tail, which is blown out of position. Consequently they head up wind at once when the wind is going faster than they are. On misty days, or with the sun behind the birds, it is difficult to tell the cock from the hen. Only practice in sport can obviate such mistakes, which are usually of some pecuniary benefit to the keeper.

The usual number of Black Grouse found together is from ten to twenty-five. Flocks composed entirely of old males often keep together from September until March. In fact, the males at this season keep much together, and arrive in a pack at the "lek." Throughout the summer the males keep together in small parties, even in July and August, when in eclipse dress; but at this time it is more common to find them scattered about singly and hiding in the dense cover, when they are difficult to find and flush.

In winter I have often seen packs of roo Blackgame in certain districts. The largest number I have ever seen at one time in a pack was at Doune, Stirlingshire, on Lord Moray's ground. At first the birds were seen on the stubbles, but caine on to the moor as we were driving grouse. The sportsmen present agreed that there were at least 300 in the flock, which I think was a fair estimate. They came once over my butt, and I killed six old Blackcocks, and with twenty-two grouse it was a "stand "I shall ever remember. Subsequent efforts to drive them were fruitless. Old inhabitants in the Black Isle testify to the great abundance of the species when the woods were young about seventy years ago, and it was a common sight to see several hundreds on the stubbles at one time. Nowadays a bag of fifty Blackcock in a day is a rare event; but the number has been killed more than once on the Duke of Buccleuch's moors in Dumfriesshire. A bag of fifty brace of Blackgame was made on Lord Lichfield's moor at Cannock Chase a few years ago. At Drumlanrig, the guns having only one muzzleloader each, killed in one day about thirty years ago, 200 Blackgame and 100 grouse.

The best bag of birds so far recorded ${ }^{1}$ is 247 (of which Ioo were cocks), at Sanquhar, Dumfriesshire. Mr. A. Stuart-Wortley also gives the following figures of bags of Blackgame made at Drumlanrig Castle-18II, I586; 1865,$1530 ; 1869,1508 ; 1870,1486$; 1871,1429 .

On the ground, Blackgame walk about very slowly, and are quiet and reserved in all their movements. In the course of an hour or two they only move a few yards, the cocks being much more watchful than the Greyhens. When wounded they can run very swiftly, but in cover they soon squat and are easily overtaken. As a rule they roost on the ground, but I have known them retire for the night to trees.

1 A. Stuart-Wortley in The Growse (Fur and Feather Series), p. 263. 


\section{The Natural History of British Game Birds}

With the first warm rays of the March sun, the bellicose disposition of the Blackcock begins to assert itself, until by the beginning of April the martial fires can be subdued no longer and find a natural outlet in open warfare, when each adult male endeavours to prove his superiority by the strength of his bill and wings. They select an open spot, generally a sloping sward of short green grass, or a rushy field near some old stone wall, and at no great distance from the moor or woods in which they have roosted. Thither the birds come at or just before daybreak to hold the "lek," as the playing-grounds are called. The males nearly always arrive first, and on alighting stand erect for a moment or two to see that all is safe, after which all caution is abandoned.

There are few more charming sights than a Blackcock's playing-ground in the spring. Whether he be sportsman or naturalist, a man who will for once arouse himself and dress in the cold dark morning will be more than rewarded for his activity by the interesting things that he will see. The morning air is freshness itself, whilst every moment brings some new things as Nature unfolds the coming day. Nature is awaking from her long sleep, and all her little songsters are vying with each other in the praise of God.

"The thrush and the lark are the first to stir, and their songs can be heard long before there is sufficient light to distinguish the singers. Soon the 'whirroo' of the Blackcock and the 'goback' of the grouse join in the chorus of sound, just as the day comes peeping in and makes out the misty forms of the little bunnies chasing one another over the heath. Then a hare will perhaps come cantering up to the place of ambush you have chosen to see the Blackcock fray, and will sit up with serene composure whilst he proceeds with his morning toilet. One creature follows another in obtruding itself on your notice, and you look with pleasure and wonder at the absence of fear displayed by creatures which at other times are so shy. Even that most timid and graceful of all animals, the roebuck, cannot make up his mind to flee in terror, as is his wont, but advances with slow and hesitating steps; he knows well there is something wrong, having got your wind, but for once regards you as an object of intense curiosity, cocking his delicate little ears and shaking his head as he runs barking round your place of concealment." I wrote these and the following lines in a notebook whilst hunched up in some large gorse bushes overlooking a playing-ground at Cawdor, in April 1900, so they have the merit of being first-hand notes of a Blackcock "lek."

"From our point of observation we can see the Blackcocks arrive on the ground, that is to say, if they are not there already. One's attention is attracted to the scene of the future triumphs and defeats by the almost continuous whirring calls of the Blackcocks, which are loud and resonant. ${ }^{2}$ On still bright mornings I have distinctly heard their notes at a distance of two miles. This call soon attracts the Greyhens, who are sure to be close at hand, as all the birds pass the night, during the period of love and war, in the woods adjacent to the tournament ring, so as to be up betimes at the first appearance of daylight. Should the birds be disturbed on their arrival at the ground, the hens are the first to take their departure, the cocks being usually too busy

1 The noise resembles nothing that I can think of, so much as the sound of a luggage-train passing over loose metals at a distance. 


\section{The Black Grouse}

settling their own affairs to take alarm at once, unless approached very close, when the whole will leave in a pack together. Unless repeatedly disturbed, they soon return.

When proceeding to attack one another (that is to say, if one of the two Blackcocks has not already beaten off one or more assailants, when it is usual for him to take up a position on a small mound and stick to it) both birds simultaneously lower their heads and arch their tails, at the same time extending the primary wing feathers and trailing them along the ground. The tails are not spread in the form in which they are generally depicted in books, i.e. upwards, except for a second, when actually in the process of raising them for expansion, but are spread out more in the shape of a fan, with a concave surface; the beautiful curled feathers almost touching the ground.

Sometimes two birds 'set' to one another as far as thirty yards apart; they then advance slowly till separated only by a few feet. Then the actual fighting, if there is to be any, begins. It, however, often happens that, as with our own bombastic race, it is all assumed, and the two, after skirmishing up to one another with every apparent gesture of rage and fury, by the time close quarters are arrived at, have come to the conclusion that another occasion will do just as well as the present for fighting it out. So the matter is arranged. More often they stand and fence, after the manner of bantams, until one, by superior tact and rapidity, suddenly seizes his adversary by the scruff of the neck and gives him a right good shaking, handling him in no gentle manner with his strong bill, whilst he beats him over the head with both wings, the act making a loud noise. When he who has come off second best eventually gets clear, he has generally had about enough for the time being, and is either chased ignominiously off the ground to hide his diminished head in some quiet corner, or flies off altogether to the nearest wood. This is only temporary, however, for he does not consider himself entirely vanquished till he has made at least another attempt to display his prowess. The victor gives his plumage a shake, and calmly proceeds to select for himself a post of vantage in the shape of a grassy mound, the possession of which he is now prepared to contest with any opponent who may be bold enough to tackle him. If the birds are at all numerous he is not long before having his wish gratified. Seating himself composedly on his little hillock, he again commences his song of war, at which some wandering knight, who has yet his laurels to win, soon takes offence and challenges him. Now, in preparation for this coming battle, the victor of the former strife entirely alters his tactics, and his attitude is purely of a defensive nature. After rising to his feet, he simply watches the advance of his adversary with lowered head, allowing the latter to waste his energies in futile attempts at getting above or behind his guard, till the process of fencing wearies him. Then, with one quick movement, he repeats the lesson he gave his former antagonist.

A good fight is very interesting to watch, and sometimes lasts a long time, when the two are evenly matched. This, however, is rarely the case, and one or the other usually gets the best of it in the first round. I have never seen them engage in a general mêlée as capercaillie, when several cocks are fighting at the same time. With Blackcocks it is all perfectly fair, Queensberry rules being strictly adhered to.

I observed a bird with lowered head and arched back in a position of defence, facing one advancing to the attack, whilst a third, anxious to fight also, danced round the 


\section{The Natural History of British Game Birds}

combatants, and though desirous of engaging the bird on the defensive, was too much of a gentleman to attack him whilst occupied with another. At intervals during each separate fight Blackcocks emit a most curious call. It is a hoarse screech, resembling that noise which is painfully familiar to us, namely, that of cats on the housetops, supplemented by the said animals being afflicted with sore throats. The sound is wild and unmusical in the extreme.

We will suppose that the observer has come early on the scene, before the Greyhens have made their appearance. The approach of one of the latter is the signal for the immediate cessation of hostilities on all sides, and intense excitement prevails amongst the assembled Blackcocks. Her approach has been observed by a single bird, who has been sharper than the rest in detecting the lady afar off. If you are at the moment watching him, you will see him suddenly draw himself up to a rigid position of attention till he is sure she is really coming. Having settled this in his mind to his own satisfaction, he throws himself into the air, and flutters up a few feet, uttering the while his hoarse note with all the power and effect he can muster. This is, of course, done to impress the lady in his favour, and arouse in her breast a proper sense of admiration, which he considers his due. His example is immediately followed by all the others, who on alighting dance about in the most absurd manner, each one trying to see who can screech the loudest and be the most ridiculous in his antics.

The sight of the Blackcock is supposed to be very keen, and is undoubtedly so at all other times. But at the period of love and war we speak of, his senses are often so dulled or excited by one or the other, that he does not seem able to distinguish a grouse passing by at a distance, from a Greyhen, when the identity of the species can be noticed at a glance by a human being who is much farther away from the object. Curiously enough, I never saw them cease their hostilities when a pair of grouse flew by, chasing each other, a single bird flying straight in their direction being always the chief cause of their excitement. On one occasion I saw them mistake a partridge, that came flying out from a wood close by, for one of their own species.

When a hen has alighted on the playing-ground, the male that is nearest to her pairs off with her and fights off any other that disputes his possession. The hen meanwhile walks sedately round her lord and master, picking about at the grass coquettishly and pretending to be feeding. Each hen on arriving causes the same general excitement, and is appropriated by one or other of the successful cocks, till the harems are filled up, one cock having at times as many as six or seven hens. As the season advances, after the first few mornings of the hens coming to the ground, they resort to the same spot each day, and stay with the same cock who has previously paired with them, and they are not interfered with afterwards by other cocks, who acknowledge the superior claims of the male to whom they rightfully belong.

Blackcocks resort to their playing-ground till the summer is well advanced; and one morning (June 4, I89o), when I got up at daybreak to stalk roe at Eskadale, on opening my window to let in the fresh morning air, much to my delight there were my old friends the Blackcocks again, whirring and strutting about as usual in the grass field. There were about ten brace of cocks and a solitary hen, and I watched an old cock showing himself off to the latter by running round and round her for fully half- 


\section{The Black Grouse}

an-hour. She was undoubtedly an old barren bird, as had she been fruitful she would have had a nest claiming her attention at that time. The keeper with whom I was staying (Donald Ross, a most observant naturalist), told me he had not noticed hens with the cocks so late as this before.

No sportsman, unless he has himself seen it, can have any idea of the speed in running that a Blackcock can attain if hard pressed and made to run, as the young cocks have to do when pursued by the old ones. Every now and again one will see these young bloods, who have arrived at a fancied state of physical perfection, make their appearance amongst the ranks of the old birds. Their pride, however, soon has its fall, and when one of the proper masters of the ring approaches to attack, they suddenly find that their courage has somehow failed them, and that he who fights and runs away may perchance be more successful on some future occasion. Then commences a hurried and ignominious retreat, in which the young bird is chased by one or more of the justly incensed ones, and endeavours by the swiftness of his feet to extricate himself from a position which his own temerity.has brought him into. This is not effected till he eventually takes flight and departs altogether. His running powers are really very considerable, and he goes for the time as fast as a partridge. No one who has seen the latter going down a hedge-row in his best form can assert that the pace is not good. As a rule, one does not form a very high opinion of the Blackcock's rate of speed. Knock him over in the open with a broken wing, and you will see he seldom attempts to use his legs to any great extent unless given time; even then he does not hurry much, but covers the ground with the deliberation and coolness which characterise all his movements, not attempting perfect concealment till at some distance from the spot where he was brought down, after which he hurries, and travels in a fairly businesslike manner.

In the spring evenings the Blackcocks again return to fight and make love to their hens, as in the mornings. Fewer birds come as a rule, and there is not the same zest and go about the show as in the early morning, and the birds, like all moving creatures, are not so lively in the evening when about to retire to roost."

In the north of England the Blackcocks commence their spring show a little earlier than in Scotland. "The most thoroughly characteristic sound of the moorland valleys," says Mr. A. Chapman," "at this season (April) is the peculiar love-song of the Blackcock. One hears everywhere the strange low bubbling note, and presently detects its author in the form of a black and white spot, far out in the centre of some wide pasture, or on the moor-clad slope of the hill. Around the excited mass of black and white feather sits his consorts, half-a-dozen Greyhens, some picking at the rush-seeds, others preening themselves or enjoying a quiet siesta, but all supremely careless, and to all appearance unconscious of the elaborate demonstrations which are being performed for their behoof. Altogether it is an extraordinary spectacle, and one that is somewhat involved in mystery. During the months of March and April the performance is incessant; even in February it is frequently audible on fine mornings, especially about daybreak. We have noticed it as early as January 3oth, but at that early period it is confined to the early hours of the day, and sometimes attended by terrible combat between 
rival monarchs. By the middle of April, however, the extreme virulence of their animosity towards each other appears to have cooled down, and small parties of Blackcocks may be seen amicably feeding together. On April 14th, in a small enclosure of meadow land, on Redewater, no less than twenty-one were thus assembled. There was no Greyhen with them, yet most of the biggest old cocks were walking about (feeding), with all their spreading tail feathers erect and partially distended, as though that position was chronic at this season."

All members of the Tetraonida have a false courtship display in the autumn. It is usually seen and heard on fine days in October, when the birds are once again in full plumage. This is called pseudo-erotism, and is most noticeable in the case of parties of Blackcocks, which resort to the playing-grounds and carry on their love antics and noises, but with far less zest than in the spring.

One October day at Dunalastair, I had gone out to shoot some Blackcocks and found very few. At midday, whilst seated at lunch, we spied about twenty Blackcocks far below us in a grassy field close to an old wall. I at once proceeded to stalk them. When I got within one hundred yards I became aware of the whirring notes and occasional cat-calls made by the cocks in spring, but much less loud in tone. The wall enabled me to creep within ten yards of the assembled pack, and looking through a hole I watched the movements of the birds for half-an-hour without their being aware of my presence. Although the cocks chased one another slightly, the whole show consisted of what may be described as a subdued plumage display. The attitudes were the same as those of the spring, but there was a want of fire and dash about it all. When the birds eventually rose, two or three of the cocks continued to call when on the wing.

I have often heard a single Blackcock call softly "curroo-curroo-curroo," a gentle purring note, as it is flushed, or comes quietly sailing along a hillside close to the ground. I think it is their "call" note to the hens, just as the cock pheasant does when he is walking about with his wives. Few naturalists or sportsmen have ever noticed this. I have only once heard a Blackcock call loudly as it flew. This was in a winter drive at Murthly. I think the circumstance must be very rare. The Greyhen seldom utters a sound, except when calling her chicks-a note like "gack-gack."

By the middle of May the depression in the ground which is used as a nest is made, and sometimes lined with a few pine-needles, leaves, or feathers. Thereon the female deposits from eight to ten eggs of a yellowish tint, spotted and blotched with rich red brown. The nest is usually placed near a wood-edge or rough cover, or in deep heather associated with blueberry and moorland grasses. In Devon and Somerset they seem to prefer the more open situations, but in Scotland I have noticed that they affect young coverts with equal appreciation. The young chicks are very similar to young capercaillie, but of course smaller and much shyer. When a fortnight old they take readily to wing, when no larger than thrushes, and nearly always fly to and settle on trees. At this early age I have found them very delicate to rear, subject to gapes, and dying when half-grown for no apparent reason. These causes, as well as death in hill-drains and the proneness of females to desert their nests at the smallest alarm, are some of the reasons for the decrease amongst Blackgame. Once scared from the nest by a wandering collie, Greyhens seldom return, and have not the complaisant 


\section{The Black Grouse}

disposition of grouse and pheasants, which often nest again or lay more eggs if the first clutch is destroyed. Whilst upon the subject of decrease, I may say that the chief causes are: (I) Lack of fertility amongst the females, after a few years; (2) the worry they have to submit to from old and unfertile Blackcocks, which never allow a young male to come to the breeding ground; and (3) indiscriminate slaughter of hens, whether barren or not; and lastly, change in the condition of local environment. In the north the grounds that are the true home of Blackgame at the nesting season are at the mercy of the laird, who likes to make every available sixpence off his property, irrespective of the requirements of the shooting tenant, who sometimes pays a truly terrible rent, and allows the farmer to run sheep and ponies over the rough ground at a small fee. This is sure to be disastrous to the Blackgame, and in lesser degree to the grouse, for it means the ever-hunting collie always on the look-out for prey or fun. Many lessees of shooting, going to their northern lodges in August, are totally unaware of the mischief caused by dogs, but it has been going on all the same. At Murthly sheep and ponies were run for many years on the rough moor round the bog, and when I got my father to buy off the farmer we increased the bag of ducks, grouse, and Blackgame 500 per cent. before we left. I could name many similar instances. Secondly, there is no systematic killing of the old Blackcocks, which as a rule survive year after year, owing to the tenant being too busy with the grouse, or not paying sufficient attention to killing them because their destruction is sometimes a little difficult. A certain way of killing these old patriarchs is stalking them with a small rifle in October, an admirable form of sport, or shooting them at the "lek," which should be done with moderation every year. The female under all circumstances should outnumber the male 6 or 8 to $\mathrm{I}$. Barren old Greyhens, too, can be shot at the playing-grounds after the I5th of May, because every Greyhen which frequents the "lek" after this date is sure to be barren. Breeding females do not return to the playing-ground after they have once commenced to sit. Thirdly, no Greyhens should be shot at any other season under any pretence whatever, as single hens, so often called barren by keepers because they have no broods with them, may have had their nests destroyed, and may be quite fertile another year. In places where Black Grouse are well treated a fine of ten shillings is imposed for killing a Greyhen, and this is an excellent rule.

My uncle, Mr. George Stibbard, rented the shooting of Syre, in Strath-naver, for ten years. In the first five, his average bag of Blackgame was about ten, and he and his neighbour, Major Burnell, who rented the other side of the valley, shot male and female more or less indiscriminately. I persuaded them to spare the hens, and during the last three seasons both shootings produced on an average from fifty to seventy brace of Blackcocks. I think that this speaks for itself. Finally, we must take into consideration the delicacy of the young birds. The Greyhen herself seldom succeeds in rearing more than five of her progeny, many falling victims to the hill-drains and the attacks of stoats, foxes, buzzards, peregrines, and hoodie-crows. Forest and pasture, like all other earthly things, are always in a constant state of change. Some grounds, especially open ones, alter slowly; others, such as plantations, may do so in a few years, and with new conditions Blackgame migrate to more attractive habitats. However, nearly all these detrimental conditions can be obviated or mitigated if the shooting 


\section{2 \\ The Natural History of British Game Birds}

tenant is observant and interested in the preservation of this noble species. Blackgame, like the roe, for some reason are not popular in the sense that grouse are, because they do not afford the easy and frequent sport offered to a number of guns that the smaller species do. They occupy a subsidiary position, and are not-to use a hateful word as applied to Nature-fashionable. The laird does not love them because of his young trees, and the lazy gunner does not care for them except as a handsome variety to the day's shooting, because their pursuit often means a failure to produce a bag.

Another very regrettable circumstance prejudicial in every way both to sport and an increase of the species, is that Blackgame may be shot on August zoth. No true sportsman cares to shoot his birds-nearly all young stock that ought to be spared-at this season, and yet the majority do so. They kill the breeding hens and all the poults that ought to be left, and whilst giving no satisfaction to themselves as shots, they do irretrievable damage. In August food is most abundant out on the moors, and the grouse shooters coming on broods at this season seldom spares them-sometimes from ignorance, but generally because it is a "fine day and a fellow must kill something," as I heard a youth once remark. Both this species and the capercaillie ought to be protected until September 25th. ${ }^{.}$Still another point which must not be overlooked is the fact that Blackgame even in the vicinity of their home grounds take long flights. For months they may resort to certain feeding grounds, and there comes a day when a change of diet is necessary, and they fly to the little moor edges and fields, where their appearance is the signal for slaughter on the part of the small shooting tenants and farmers who have no interest in preserving them. Like the woodcock or duck they are to him occasional visitors, and are killed by any manner of legitimate and poaching device. I have known excellent Blackgame grounds ruined by little outside tenants. Finally, unreasonable moor-burning, as practised on Dartmoor and Exmoor right into the nesting season, is very prejudicial to the interests of the species.

In their early stages young Black Grouse are very fond of insects, especially ants' eggs, and I have seen large ant-hills torn to pieces by the Greyhens, which have been in the habit of visiting them until not an egg was left. This, with rush and grass seeds, is a favourite food. In August the adult plumage comes in, and the young Blackcocks are the first to leave the mother. For a short time they lead a solitary life, and by the end of September assemble in what may be termed mixed "immature" packs, in which a stray old Blackcock may sometimes be found. Young Greyhens breed the following spring, but it is three years before the Blackcock is allowed to fulfil parental duties.

Young Blackgame are very slow in reaching maturity. Although hatched early in June, they are not full grown until the end of September. During this period they are the most delicate and easiest to kill of all our game birds. Even when nearly mature they seem to be extremely tame, and are almost incapable of flight if flushed twice on a wet day. But with the accession of bodily strength and full plumage they soon become the wildest of our game birds, with the exception of the cock capercaillie.

\footnotetext{
1 As this work goes to press many sportsmen and naturalists will be rejoiced to see that Viscount Dalrymple has introduced a Bill to extend the close time for Blackgame to prevent their being shot before October $x$ st. This will doubtless become law, and in the main it is just, but it will most certainly meet with the disapproval of many Highland shooting tenants, as it will entail but little sport with the birds. The average tenant leaves Scotland by October 5 th, so it is hard upon him and his friends. September 25 th would have been a much better date.
} 


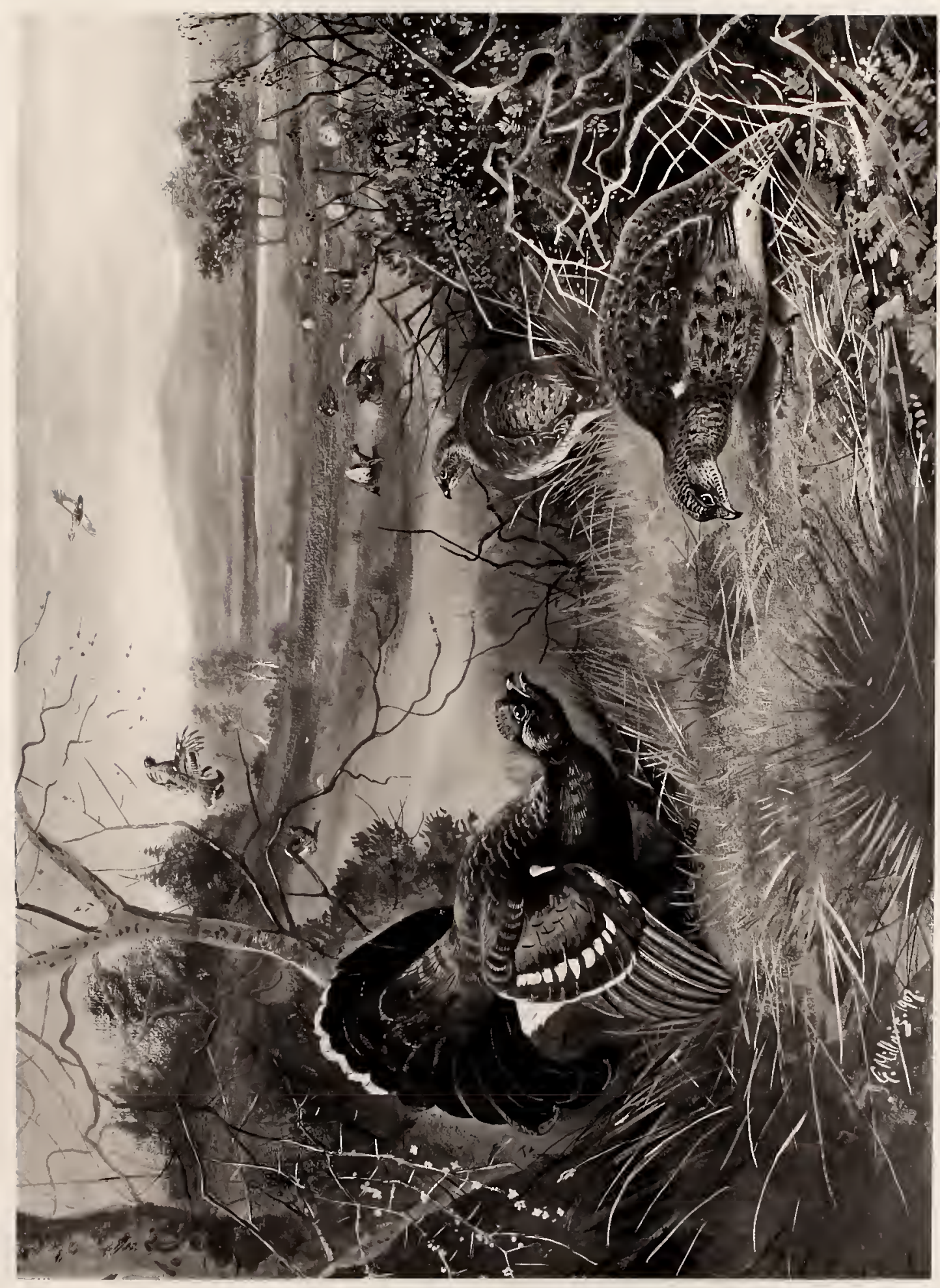



The methods of shooting Blackgame are too well known to be described, as excellent accounts will be found in many standard works. No one, however, mentions the best sport of all, namely, stalking old Blackcocks with a pea-rifle or .22 long (Savage), fitted with a high-power telescopic sight. It has all the elements of deer-stalking, and is not nearly so expensive. When packs of Blackcocks are coming to the "stooks" or frequenting grassy fields for their pseudo-erotic display, they are not very difficult to stalk, and the sport with the .22 Savage or Stevens (Winchester .22 is not quite strong enough) is one of the best I know of. They are not much alarmed at the explosion of the small nitro cartridges, and I have killed four Blackcocks out of a pack before the rest made off. It is, however, absolutely essential not to move or make the slightest sound after firing, and to kill the bird at which you have aimed, dead. If it flutters, then the other birds at once take alarm. I have of recent years gone in much for this sport, and have killed large numbers of partridges, wood-pigeons (in the courting season), \&c., and can recommend it as one of the best sports I know of, and far superior to a great deal of what is termed "good shooting." Sport is altogether a comparative term. Some birds brought to the gun or walked up, may not be called "sport," whilst shooting Blackcocks or partridges on the moor or field with a rifle may be termed "poaching"; but it is nevertheless, when conducted in a proper manner and kept within limits, a very high-class form of the chase, requiring skill and the employment of the hunter instinct, the two great essentials for enjoyment of sport of any kind.

With regard to their relations towards other species, I think that Blackgame in no way interfere with capercaillie or pheasants. It is scarcely necessary to state that capercaillie can look after themselves very well; in no instance have I heard of one of this species ejecting the other from the woods. When Blackgame have left certain woods it is not because of the presence of other game, but because these localities have become unsuitable to them, and they would have abandoned them in any case. The woods most favoured by pheasants in Scotland are also too open in character to suit Black Grouse, and where pheasants are placed in woods full of deep heather they scatter to such an extent that Blackgame, who are generally in packs, take no notice of them. Moreover, pheasants will always work towards cultivated lands sooner or later, whilst Blackgame avoid cultivated areas, except during a short period in the autumn. The general "improvements" in forest lands have done much to account for the decrease of Blackgame. Like the female capercaillie, the Greyhen is apt to become a wanderer in the spring, and it is to these birds, unattended by males, that we owe local extensions. When such females have resorted to new grounds early in the season and there are no Blackcocks about, they will on rare occasions mate with both pheasant and red grouse, and it is interesting to note that, although the two species are so widely separated, crosses with the polygamous pheasant are far commoner than with the monogamous grouse. Of the first-named hybrids, I have recorded five or six examples, and have seen about twenty other specimens, whilst the Rev. Francis Jourdain records no fewer than fifty examples. The cross cannot, therefore, be considered very rare.

Yarrell records eleven instances of this cross, ${ }^{1}$ but this is augmented to twenty-six British specimens by M. Andre Suchetet, ${ }^{2}$ although some of these are open to doubt. The 


\section{The Natural History of British Game Birds}

first recorded instance is mentioned by Gilbert White in the "Observations on Birds" appended to an early edition of the Natural History of Selborne. The specimen was killed at the Holt, and was supposed to be a hybrid pheasant and domestic fowl. In I883 the Hon. W. Herbert identified it as a Black Grouse and pheasant cross. Subsequent examples have occurred at Whidey, Plymouth, 1829; Cornwall, 1834; another probably of the same brood mentioned by Rodd (Birds of Connwall, p. 77); two (from a brood of five) at Newington, Shropshire, in 1834; Corwen, Merioneth, and now in Mr. Beville Stanier's collection (formerly Lord Hill's), killed prior to 1836; Lochnaw, Wigtownshire, 1835; Alnwick Castle, 1837; Alnwick, 1837 (British Museum); Devonport, 1839; Felton, Northumberland, I839; Belsay, Northumberland, 1842 ; and so on to the number of fifty, of all of which full particulars may be obtained by referring to an excellent article in the Zoologist, September 1906, by Mr. Jourdain. Charles St. John, in his Natural History and Sport in Moray, had evidently seen several unrecorded hybrids of these two species, for he remarks (p. 22I) that the cross is "not very rare."

With regard to black and red grouse hybrids, which are rare, I have seen several specimens. One killed at Glen Mazarin, September I I, I889, I figured in Game Birds and Shooting Sketches (p. 36). Mr. H. E. Forrest records two examples of these hybrids in the Vertebrate Fauna of North Wales (p. 307). One was killed at Yspytly Moor, November 20, 1897, and the other on December 9, 1895, at the same place. I extract the following passage from the Bulletin of the British Ornithologists' Club, February 2, 1909 :-

"Mr. J. G. Millais exhibited two immature examples, male and female, of the hybrid between the Red Grouse (Lagopus scoticus) and the Black Grouse (Lyrurus tetrix), killed in Walcs, and made the following remarks :-

'It would be natural to supposc that species which are closely allied and which frequent the same ground would often interbrecd; but such is not the case. It is well known that Black Grouse and Capercaillie frequently interbreed, and there are four or more known instances of hybrids between such diverse species as the Pheasant and the Capercaillie, but crosses between Black Grouse and Red Grouse, or Red Grouse and Ptarmigan, are extremely rare. This may be accounted for by the fact that the first-named is polygamous, whilst both the Red Grouse and Ptarmigan are monogamous. Previous to the two specimens exhibited, I have only seen two examples of the cross between Black Grousc and Red Grouse, both killed in Scotland. Mr. J. A. Jones spoke to me one day concerning two Grouse which he and his son had killed at Llanerch bog, near Bala, North Wales, in August 1908. On examination they proved to be undoubted hybrids between the last-named species. Both are immature birds, male and female, and exhibit very clearly the characteristics of both parents. The back, wings, and scapulars are similar to those of the immature Black Grouse, whilst the new plumage, coming in on the breast and flanks, is like that of the "White "form of the Red Grouse, being deep chestnut and black widely tipped with white. The feet, legs, and forked tail (in the case of the male the tail is missing) are similar to those of the larger parent. All the seven young birds in the covey were killed, and they are now in the possession of Mr. J. A. Jones, who has kindly allowed this pair to be exhibited. Neither of the parent birds were seen. It seems a great pity that the whole covey was destroyed, for had any reached maturity they would have been very beautiful and interesting birds, quite dissimilar to the other specimens of this hybrid that I have seen.'"

Mr. Ogilvie Grant remarked that it was many years before he was able to obtain an example of this hybrid for the Bird Gallery in the British Museum, which now possesses two adult male examples. 


\section{The Black Grouse}

"The first, procured through the good offices of Mr. Rowland Ward, was one of a pair of adult males which had been killed at Millden, Forfarshire, on the Ist of October Igoo, by Mr. J. L. Cadwalader. The second male was presented to the American Museum of Natural History, New York. Subsequently a second adult male was presented to the British Museum by Lord Tweedmouth, but bears no particulars regarding its capture. Mr. Grant had never seen a female example of this rare hybrid, nor had he previously examined young birds, which appeared to be of very special interest."

The female example, which is unique, Mr. Jones kindly presented to me, and it is now in my collection. Mr. G. Ashley Dodd informs me that he possesses a specimen of this hybrid killed in Scotland. This specimen is now in the British Museum, as well as another, an immature male, exhibited by Mr. O. Grant at the B.O.C. meeting, February I7, I909. Mr. Grant thus describes the latter :-

"The specimen had been killed on the 6th of October Igo8, by Mr. F. W. Stobart, in Glen Trool, Kirkcudbrightshire, where Black Grouse are extremely plentiful. It was shot during a drive when flying in company with four Red Grouse. The bird was exactly of the same type as the two adult males already in the British Museum, but it still retained a considerable amount of the first plumage, particularly on the sides of the head and neck, where the feathers were mostly light reddish-buff barred with black. The bill was large and rather coarse, and the basal portions of the toes were feathered as in the Red Grouse, while the terminal portions were naked and pectinate on the sides as in the Black Grouse."

I have never examined nor heard of a pure white British variety of the Black Grouse, although I have seen some beautiful examples in the Scandinavian museums. Even partially white examples are rare. Some years ago I saw a Greyhen with pure white wings flying near Amulree, in Perthshire. I have seen four pied cocks, the first two beautifully speckled all over with white feathers, and killed in Lanarkshire by Mr. J. Allan in December I890. The third example was one I have figured in Game Birds, and belonged to the late Mr. Marshall of Taunton; and the fourth was a beautiful specimen, mounted by Rowland Ward in December I908. It was sent in by Mr. D. Hamilton, and was killed at Burgany, Dailly, in Ayrshire, in that month.

"The head, neck, and upper surface are practically normal, with the exception of the upper tail-coverts, which are white, the feathers of the wing coverts, which are more or less edged with white, and a few white feathers on the sides of the neck. On the under surface there is a good deal of white plumage, with which are interspersed white feathers with black edges. This albinistic region extends from the lower neck to between the thighs, where it merges into black; at a little distance from the normal hue of the throat it is narrowed on each side and then gradually widens out till it stretches nearly across the abdomen. . . .

"Tring Museum is rich in albinisms of this species. At the meeting of the British Ornithologists' Club on April 25, Igoo, the Hon. Walter Rothschild exhibited seven mounted specimens (four males and three females) of Russian origin. The following descriptions are from the Bulletin of the Club. Males : (x) Remiges and rectrices mostly pure white; (2) almost the entire under side white; (3) pied, wings with a great deal of white; (4) silvery grey. The three Greyhens were respectively greyish white, pure white, and grey, buff, and black in curious mixture. Three skins of Greyhens were also shown, two from Russia and one from an old collection; one of the Russian specimens had the under side, from the fore-neck to the tail-coverts, white, with some blackish markings, and the wing coverts with very broad white edgings; in the other the under surface was pied. The third specimen was white, with brown markings on the head and neck, the tail feathers pale brown towards base, and some of the body feathers with faint brown shades. In his Game Birds Mr. Millais gives a plate representing some of these specimens." 1

1 Field, Dec. 5, 1908. 


\section{The Natural History of British Game Birds}

Another pied Blackcock, killed in Wigtownshire, was presented to the British Museum in 1908 by Mr. G. Ashley Dodd. The normal plumage is covered with crescentshaped bars of white.

There are at least ten whole or partial albinoes in the Bergen Museum, and I have lately seen a very fine white Blackcock in the small museum at Khristianssand. I only know of one example of the Blackcock assuming the plumage of the female, that of a specimen in the Hon. W. Rothschild's collection, which I have figured. The bird is supposed to have been taken in Russia.

Cases of barren females assuming the plumage of the male are so common, that I will not enumerate them. I have seen at least roo British examples, and every season a few pass into the taxidermist's hands. Most of these possess almost black under parts with white edgings, the throat white, like the Blackcock in eclipse, and the whole of the upper parts very dark and grizzled, a mixture of the plumage of both sexes. The under tail-coverts are generally white, or white with black markings, whilst the outer tail feathers are black, and inclined to curl outwards. A very beautiful female, scarcely darker than the ordinary type, in my collection possessed a perfectly shaped Blackcock's tail. It was killed in Perthshire about fifteen years ago. This variety is very rare, and I have only seen one other example, now in the Bergen Museum. 


\title{
Genus : Lagopus
}

Members of this genus are easily recognised by having the feet and toes well covered with feathers. The tail is of moderate length, more or less square when spread, and composed of sixteen feathers. The genus embraces the Red Grouse, the Willow Grouse, the four species of Ptarmigan and their innumerable sub-species.

\section{THE RED GROUSE}

\author{
Lagopus scoticus, Latham
}

Local Names.-Grouse, Muir-cock, Muir-hen, Moorfowl, Muirfowl, Gor-cock ; Coilleach-Ruadh (Redcock), Coilleach-Fhraoich (Heathercock), Cearc-Fhraoich (Heather-hen), lan Fraoich (Heather bird) (Gaelic); Cochiad (Red game), Coch y Grug (Red of the heather), lar Goch (Red hen), Ceiliog and lar y Mynydd (Cock and hen of the mountain), Grugiar (Heather-hen) (Welsh).

No birds pass through such a bewildering series of changes as members of the genus lagopus. Except for short periods, they are in a chronic state of change throughout the year, and when this is further complicated by several distinct forms, as is the case with the Red Grouse, it will be seen that the naturalist has no easy task to explain in lucid language, without being too technical, the various intricacies of the subject. I was the first to describe, in 1892 , the three forms of the Grouse: the red, the black, and the white-spotted; and to explain the various types and phases of plumage through which they pass. The following account, being intended for the use of naturalists, I have somewhat amplified from the original text, giving fuller details with regard to the moults, of which I have made a special study during recent years.

Mouits.-Both the male and female Red Grouse have two complete moults in the year, the sexes changing at different seasons. In the male, the first takes place in summer, sometimes as early as June Ioth. He remains in this until the end of September, and then assumes the full winter dress gradually until early December, when it is complete. Sometimes it is quite full by October Ioth, but I have noticed males of the white form get a further access of white in December. In this winter dress the male remains all through the winter until March.

With regard to the moults of the female, she also has two distinct moults: the first taking place in the autumn, later than the male $;^{1}$ and the second in April, when the full summer plumage is assumed, and lasts until late September.

With regard to the assumption of the breeding dress of the female, it is necessary to say a few words. In nearly every case this plumage is not effected by a complete moult, but by a partial moult and a partial pattern change; this takes a long time to

\footnotetext{
1 Her principal moult, in which tail, wings, and all parts are renewed, commences about July zoth. By August $\mathrm{r} 2$ th all the
} large feathers have fallen or are in process of renewal. About September $1_{5}$ th the winter dress is quite complete. 
complete, especially amongst the flank feathers, which often begin to change in pattern as early as December. With the renewal of pigment much colour is also added to these feathers in the early days of spring, and they present a different and warmer tone in March when the spring moult is in full flush. The same may be said of the front of the neck and chest, where the summer plumage is attained by a mixed colour and pattern change amongst old feathers and an accession of new ones. So that, on the whole, it may be said that the female gets its breeding plumage by a half moult, and a half pattern and colour change. We must not, however, lose sight of the fact that female Grouse and other birds vary enormously in individual constitution, and that some being more vigorous than others will attain their breeding dress wholly by means of a moult. Mr. Ogilvie Grant, who has made a close study of the species, asserts that every female attains the whole of the summer dress by means of a moult, but though this may be regular, I am not at all convinced that it is the invariable rule.

Until I 909 naturalists do not seem to have devoted much time to the study of the summer plumage of the Red Grouse, probably owing to the difficulty of obtaining specimens. Mr. Ogilvie Grant, in his excellent little book on the Game Birds (p. 29), considers that the Red Grouse, being an insular form, living in warmer latitudes where a white winter dress is unnecessary, has gradually dropped the spring moult necessary to his northern relation, the Willow Grouse. And in the main he is right; but not completely so. He states definitely, moreover, that the male breeds in the "winter dress," suggesting that there is no accession of new feathers similar to the summer dress of the Willow Grouse, and in this he is incorrect.

Some years ago the proprietor of a deer forest, who was anxious to exterminate the Grouse on a certain hill, allowed me to shoot three pairs in May for my collection. I confess that parts of the plumage of the male puzzled me, and I was in doubt whether the brilliant dress was altogether the result of repigmentation or fresh moult. Some new feathers were coming in and others were nearly complete on the neck, and this made me think that Mr. Grant's view of the winter-summer dress without additional feathers could not be maintained. An opportunity for thorough investigation of the question did not occur till I909, when I applied to certain friends to help me to solve the question. Through their generous support I have had over fifty freshly-killed cocks sent to me between February Ioth and July Ist. To show how difficult it is to get specific information on a simple phase in the life-history of one of our commonest birds, I may mention that not one of my correspondents or their keepers, who had spent their lives on the moors, could state definitely whether the cock Grouse had a breeding plumage, or even a summer moult, or not. A typical answer was that of Mr. R. Rimington-Wilson, who writes: "I have spent my life on the moor edge, and I am ashamed to say I do not know."

The result of my examination of these cock birds is as follows :-

From March Ist until March 24th not one new feather is found in the winter plumage of eight cocks from Yorkshire, Elgin, Inverness-shire, and Perthshire, but as the month advanced the comb was much developed, and a richer red colour suffused all the red feathers of the plumage, which also achieved a brilliant gloss. A considerable pattern change was also noticeable. The access of colour is due to repigmentation, consequent on the birds getting into a high condition as the snow melted. The first bird to prove 


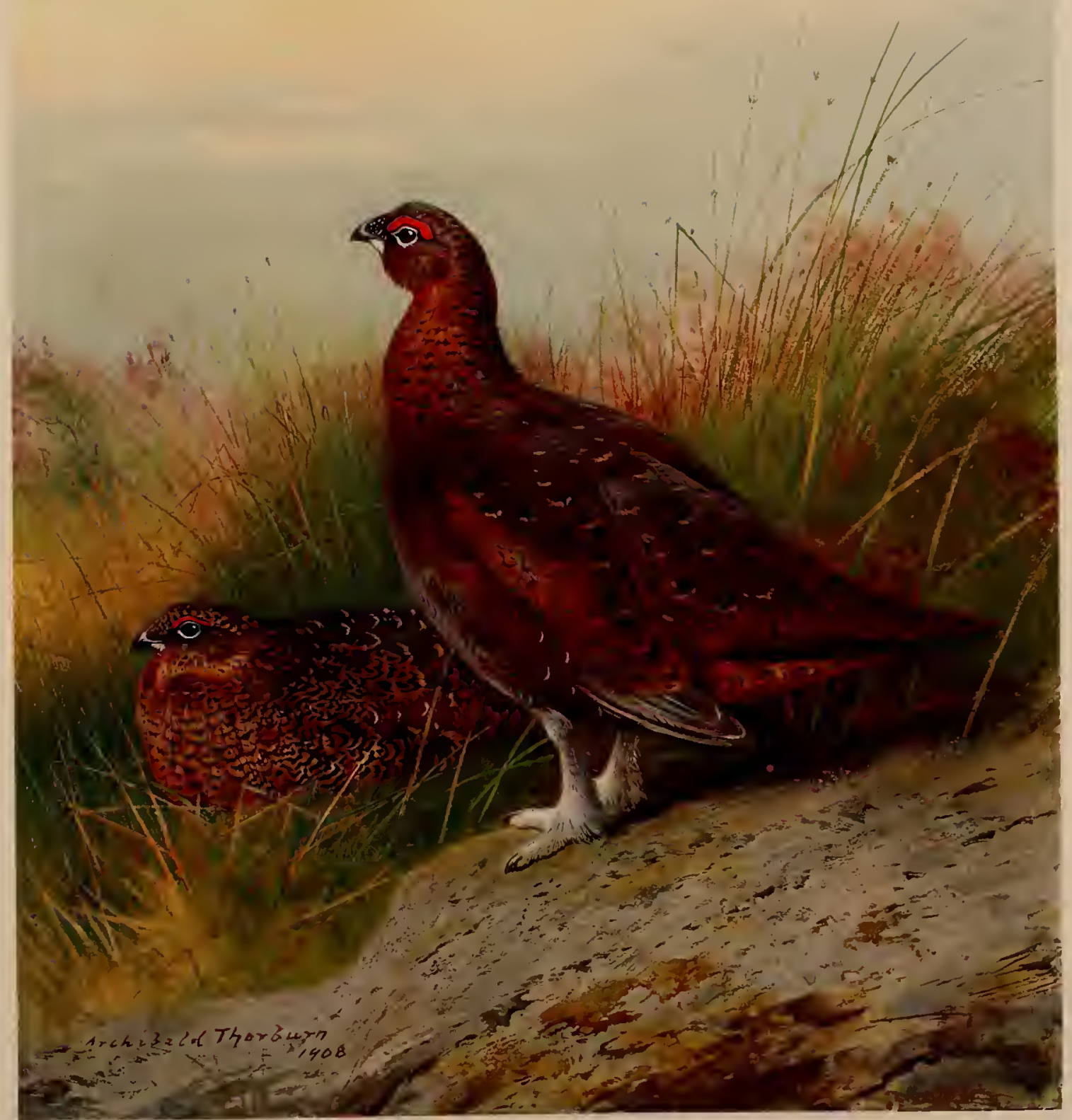

THE RED GROUSE

Lagopus scoticus, Red form-March 

that the cock Grouse has a partial breeding dress came from Cambusmore in Sutherland, on March 24th. A large number of new rich black and golden-yellow feathers were found coming in all over the crown, cheeks, throat, and back of the neck, but not on any other part of the plumage. From this date until the end of the month five specimens all showed a similar infusion of new feathers to the same parts, and were also brighter in their repigmented parts than early March birds. On March 3oth I received from Bleaton Hallet in Perthshire, the first bird to moult the feathers off the legs and toes, whilst on June 15 th a male from Bearnock, Inverness-shire, had only commenced to shed its long feet and toe feathers. ${ }^{1}$

Throughout March and April all specimens exhibited the influx of new feathers of brilliant black and yellow amongst the old winter red ones that had been recoloured. These additions extended over the whole of the head and neck, but not as far as the nape, and although a number of feathers, evidently moulting, came from a bird from Alness (April 2oth), no true autumn moult, except on the parts noticed and on the feet and legs, takes place until early June. There is a tendency, but only a tendency and not a general change, amongst the black and white types of males towards red in the repigmented summer plumage; for on April 13th I received two fine males of a black form from Nairnshire, which were still as black as any full winter birds. In the case of the very white types found in Sutherland and on high grounds, the white under parts are generally darker than during winter, and this is due not to tip-wearing, as we might expect, but to an extension of the black towards the exposed parts of the feathers-in fact, to a pattern change. Nature abhors contrasts, and takes this method of assimilation to surroundings.

On May Ist a very interesting bird was received from the Duke of Devonshire's moors at Buxton in Derbyshire. This has the whole of the head, cheeks, throat, and neck complete with new richly-marked black and yellow feathers, whilst a few new golden-pointed feathers were coming into the nape, back, and scapulars. Another similar bird from Broomhead Moor, Yorkshire, received on May i 3 th, had a large number of bright summer plumage feathers entering the plumage all over the breast, nape, scapulars, and tail-coverts, \&c., but not on wings or belly. These two birds are of the highest importance, because they seem to me to show that in individual cases the cock Grouse does have, to a considerable extent, a distinct breeding dress, which must not be confounded with the true autumn moult which, as Mr. Grant has already correctly stated, commences in some cases as early as June 6th. These "summer-plumage" features would doubtless form part of the true autumn plumage, and would be cast somewhere about mid-September, but that does not seem to detract from the fact that they are a separate and ornamental attribute of the plumage achieved by the bird for decorative purposes during the time of brilliance, whilst in colour they are in no way quite similar to the dull buff and black autumnal dress assumed in June.

Broadly speaking, and without losing sight of individual variation due to condition, climate, season, and latitude, it may be said that from the 18th of June until the end of that month the cock Grouse is in full:moult--tail, primaries, and all. The legs and feet

\footnotetext{
${ }_{1}$ In the moult on these parts of the cock Grouse alone I found great irregularity. Although other parts were normal, the toe and leg shedding of feathers seems to bear no relation to the rest of the plumage.
} 


\section{The Natural History of British Game Birds}

are generally bare, and it only keeps such feathers as have come into the plumage since March. In this sombre dress of buff and black and.faded summer feathers nearly all males of the several forms are alike, and it would seem that this dull plumage is somewhat similar to the eclipse plumage of the ducks. In reality it might be named the "eclipse" dress of the cock Grouse; for with autumn-that is to say, early September-commences the big change to winter, when all feathers, except the primaries, secondaries, and tail, are again renewed. This, however, we need not discuss, as I have already explained it at length.

In conclusion, it is the case that the summer or breeding plumage of the cock Grouse is achieved, for the most part, by repigmentation and pattern change of most of the winter feathers below the neck, and above that part by a gradual spring moult (differing considerably in individuals as to date), whilst in the case of certain males these ornamental feathers may extend in small numbers to the nape, scapulars, chest, back, and tail-coverts, thus partly forming an ornamental nuptial dress similar in character to that of the Willow Grouse. It is also a new and curious fact that the male should moult the feathers of the legs and feet at any period between March 3oth and June I7th, as the margin of time is so very wide.

The following list of birds gives details of the plumage of the most interesting specimens. The numbers indicate conspicuous changes:-

\section{Male Grouse sent for Examination during the Year igog}

I. March I6th.-Bearnock, Inverness-shire (H. F. Wallace). Richly coloured bird in fine plumage with good gloss; the reds and blacks are more brilliant than during winter; comb well developed; feet and legs as in winter; no new feathers.

2. March 24th.-Cambusmore, Sutherland (Mrs. Wilfred Loder). A large number of new rich black and golden yellow feathers coming in all over crown, cheeks, throat, and back of the neck, but the rest of the plumage winter feathers well repigmented with fine gloss; rump almost blood-red, with some feathers not recoloured and dull; legs and feet as in winter. A very fat bird in high condition.

3. March 3oth.-Bleaton Hallet, Blairgowrie, Perthshire (J. M. K. Marshall). Repigmentation very rich, together with considerable pattern change on the whole plumage except crown, cheeks, throat, and neck, which are being renewed with brilliant breeding dress feathers. The feathers of the legs and feet have fallen and are nearly bare.

(The legs and toes of another example from Pitlochry, sent on April Ist, were also in full moult.)

From this date until May Ist all birds were acquiring or had gained similar plumage, some moulting feet and toes, and others not doing so.

4. May I st.-Buxton, Derbyshire (His Grace the Duke of Devonshire). New head and neck feathers complete, but in addition many new rich golden and black feathers coming into nape, back, scapulars, and breast, but none on tail-coverts, wings, or belly. Old winter feathers mostly repigmented and possibly repatterned; legs and toes bare.

(A bird from Broomhead Moor, already referred to, was even more advanced, having feathers in tail-coverts as well.) 


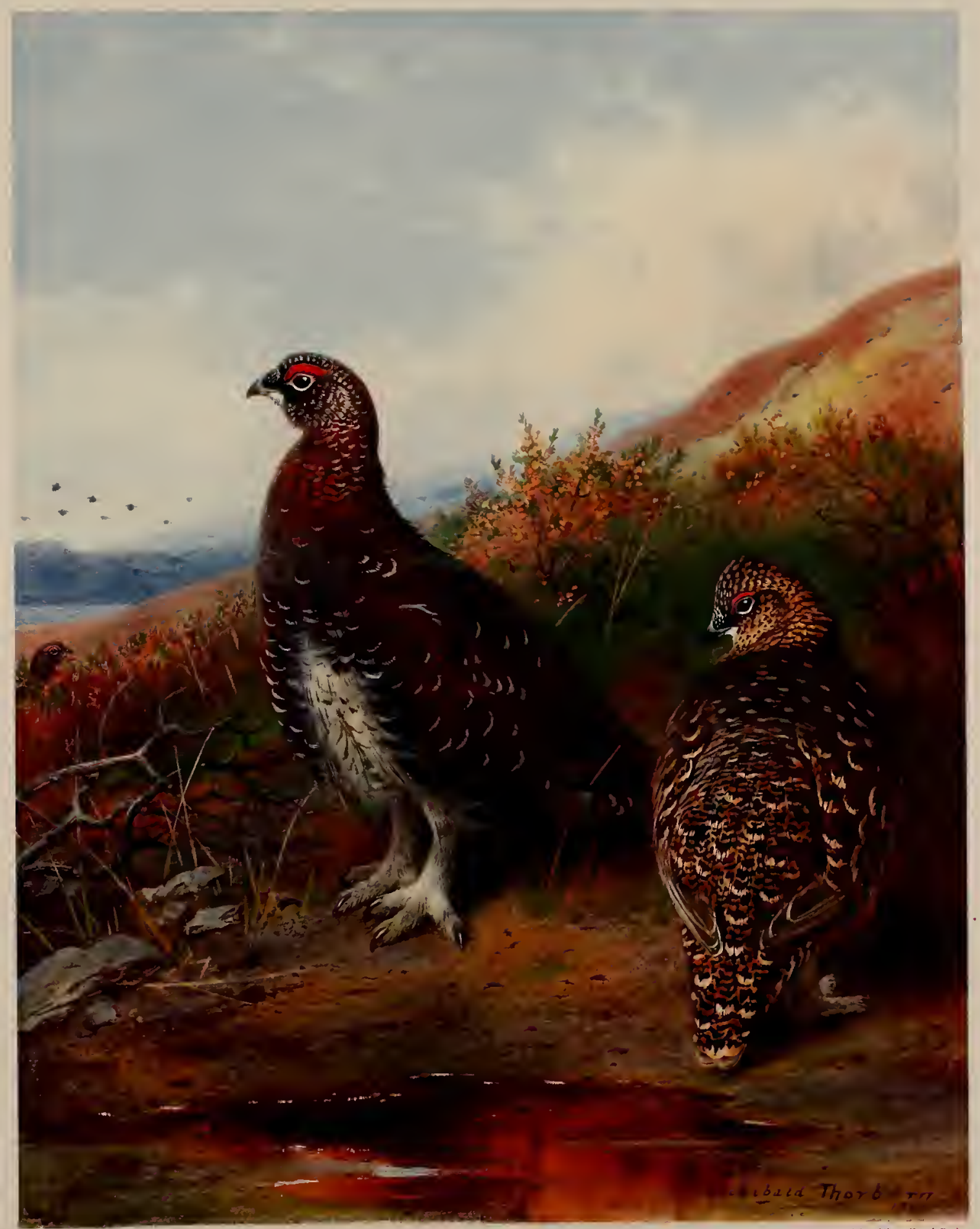

Yrinted by Albert Fisch.Berin

THE RED GROUSE

Lagopus scoticus, White form 

5. June I2th.-Broomhead Moor, Yorkshire (R. Rimington-Wilson). General moult over the whole plumage, except on those parts to which new summer plumage had already come since March; legs and toes devoid of feathers. Primaries, tail feathers, and all parts being renewed and passing in eclipse plumage.

After this date, with the exception of a few backward birds, all specimens were passing through similar change. ${ }^{1}$

Forms of Plumage. - The various forms of both males and females are as follows :-

Males. - The red, the white-spotted, the black, and every intergrading variety between all these forms.

Females.-The red, the white-spotted, the black, the buff-spotted, and the buffbarred. In the case of females intermediate forms are rare, for they generally assume one or other of the phases in its pure state.

In the autumn plumage of males there is a great similarity amongst all the various types; the white being only slightly lighter than the black. The upper parts are black margined and irregularly barred with buff, the bars being generally transverse. The whole of the lower neck, chest, breast, and under parts are black, with wide buff bars, some of the lower breast feathers being slightly edged with white or grey. At the end of the breeding season a complete moult takes place even to the legs and feet feathers, whilst in August or September the nails of the claws are renewed. With regard to the winter-summer plumage of males the assumption is gradual, many of the eclipse feathers being retained until November; after this no alteration takes place until the following spring, when the (partial) breeding dress feathers come in. In the case of females in winter plumage each of the different forms (afterwards described) assumes its autumn-winter dress from August until September; but when the full summer dress arrives in April, we see a general conformation to one type for all forms, that of a rich black barred with chestnut, with the feathers of the neck, chest, and upper parts edged with buff bars or spots.

Adult Male: Red Form (Winter-Summer Plumage).-This phase is usually to be found in boggy districts where there are no high mountains. It is the common variety in Caithness (where it is very dark), the Hebrides, and the south and other low districts of Ireland, when the plumage is complete in November. In full dress the general colour may be said to be a rich dark red, finely barred with black all over; tail and primaries, brownblack; breast feathers and angles of the mouth edged with white, even in May, but in the south of Ireland only those at the lower edge of the upper mandible are white. The legs and feet are suffused with dull grey. In the centre of the back and scapulars there are always a few black feathers with irregular and fine buff edgings. The cheeks, nape, and throat are a pure red, almost blood-red in some examples. Individual males of this type are found all over Great Britain, but they are distinctly rare on high grounds.

Black Form (Winter-Summer Plumage).-This is a more uncommon variety in its pure state, as it is usually found in form mixed with the red and white phases. It is indeed difficult to assign the point where it may be called a black form or a melanic variety. Yet it is of such common occurrence in the high ranges of Ross, Sutherland, and Perthshire

${ }^{1} \mathrm{My}$ best thanks are due to the following friends, who have so kindly assisted me with one or more specimens: Earl Cawdor, H. F. Wallace, Capt. Brander Dunbar, Mrs, Wilfred Loder, C. W. Dyson Perrins, J. C. Williams, Beville Stanier, M.P. His Grace the Duke of Devonshire, Herbert Pullar, P. D. Malloch, H. Rose of Holm Rose, J. M'L. Marshall, A. Wynne Corrie, R. Rimington-Wilson, E. M. Eversfield, The Macleod of Macleod, G. W. Millais. 


\section{The Natural History of British Game Birds}

that we must regard it as a true form. I have also seen good examples in Staffordshire. Males perfectly black all over are rare, but I have seen about ten examples, three from Holm Rose in Nairnshire, where the black form is very common. This form may be said to be black all over, with a few bars of reddish brown on median wing coverts. The neck shows some red feathers amongst the black; the cheeks are edged with pure white as well as a few of the lower breast feathers. The thighs and legs and feet are generally white.

White Form (Winter-Summer Plumage).-In December this phase may be described as being a perfect mixture of the black and red forms, but with the whole of the feathers of the lower parts and wings, except the primaries and secondaries, broadly edged with pure white. In fine examples the whole of the ventral surface appears to be white. The legs and feet are also white, and very conspicuous as the bird runs along the ground. The cheeks and upper throat are also broadly banded with white, and in some extreme cases (notably from the high mountains of Ross and Sutherland) I have seen beautiful examples with the whole of the back as far as the tail-coverts broadly edged with pure white. This shows how climatic influence affects birds of this genus. Here we have both latitude and elevation combining to cause what is more than a tendency towards the white winter dress of the Arctic Willow Grouse. If there were high mountains in the north of the Shetlands, and Grouse were to be placed there, I think we should get some very interesting birds in winter plumage.

Adult Female: Red Form (Winter).-It is curious that this form should be extremely rare in the bog areas frequented by red males. It is most common in the mountain districts of Perthshire and Inverness-shire. A general red tone pervades the whole plumage, the black bars being narrow. The head and neck is usually very dark with few buff spots.

White-spotted Form (Winter).-Always found in the same high latitudes as the white males. The lower parts are well covered with white, the upper parts are similar to other types of females. Cheeks and feet often white, but I have never seen a female of the white-spotted form with white feathers extending over the scapulars, back, and tail-coverts, a common variety amongst winter males in Ross and Sutherland.

Black Form (Winter).-This variety is extremely rare. I do not think I have seen more than three specimens, and they were not nearly so dark as ordinary black males; even then there was a large amount of red in the plumage.

Buff-spotted Form (Winter).-A very common type found in all districts. The whole plumage is buffish yellow boldly furred with black, especially so in Donegal and Welsh specimens, and with large buff spots on tail-coverts, scapulars, and mantles. In high grounds these spotted varieties often have a good deal of white on the under parts. In some Irish specimens the under tail-coverts are a rich red. In Yorkshire these are known as "Yellow hens."

The Half-barred Form (Winter).-This is the commonest form found in our islands. In the Hebrides and the south of Ireland a similar plumage is found in winter as in summer, in spite of the spring moult. ${ }^{1}$ The whole plumage is buffish red with broad transverse bars of black, except on the belly, breast, and flanks, where black markings

1 Two adult females of this form killed by me in Cork, in November $\mathrm{I} 892$, are exactly similar to two Scotch females killed in May in the Athole forest. 


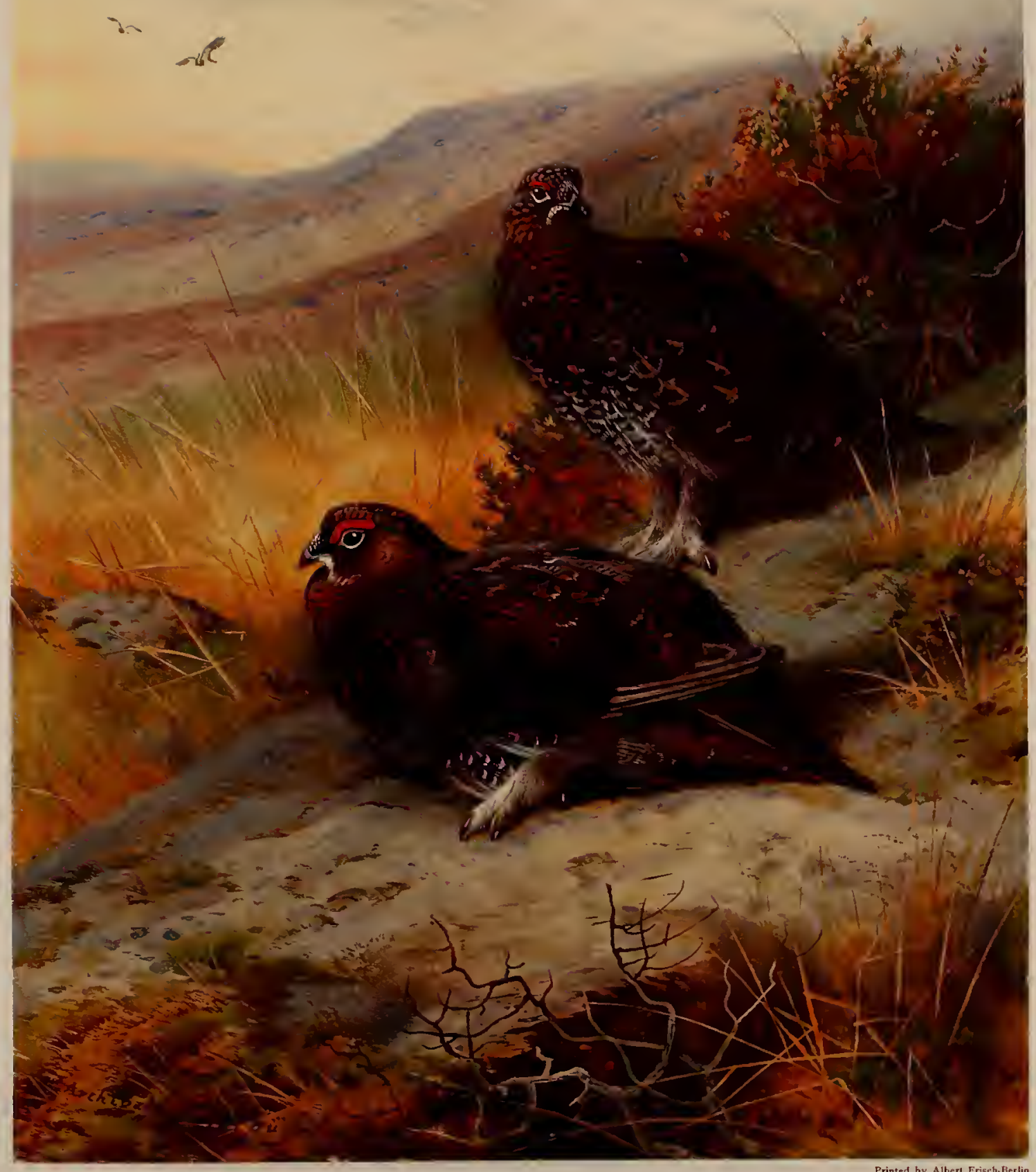

THE RED GROUSE

Lagopus scoticus, Black form 



\section{The Red Grouse}

are generally hooped, narrow, and vermiculated. Large spots of a paler buff appear on the scapulars and tail-coverts. Irish specimens are not so white round the eyes as Scotch ones.

The largest Grouse in our islands come from the moors of Caithness and the south of Ireland. I have weighed two males from Cork and one from Caithness, as well as an exceptional bird from Cawdor (Nairnshire), which turned the scale at $2 \mathrm{lbs}$. Mr. W. H. St. Quentin mentions (Field) a pair of Grouse killed (in Sutherland) which weighed 4 lbs. Adult males usually weigh $1 \frac{1}{2}$ lbs., and females are a few ounces less. The smallest Grouse I have seen come from the hills of Donegal, males weighing about $\mathrm{I} \frac{1}{4}$ lbs. Messrs. Ussher and Warren record ${ }^{1}$ an Irish male from Kerry of the unusual weight of $2 \frac{1}{2} \mathrm{lbs}$.

Male length, 15.5 in.; wing, 8.1 in.; tail, 4.8 in.; tarsus, I. 4 in.

Female length, 15 in.; wing, 7.8 in.; tail, 4.3 in.; tarsus, 1.35 in.

Yorkshire Grouse average $24 \mathrm{oz}$. (males) and $20 \mathrm{oz}$. (females), though examples have been known to scale as much as $32 \mathrm{oz}$. and $24 \mathrm{oz}$.

Young.-At first the young are covered with yellowish buff down; the head and upper parts being barred and blotched with black. In first plumage the immatures are somewhat similar in colour to adult females, except that all the black markings are smaller and more vermiculated. About the end of July the flank feathers of the adult plumage appear, and the whole dress is moulted and complete in winter plumage by the end of September. Young birds in October are often quite as large as adults, and the old Scotch methods of determining age by holding a bird by the lower mandible to see if it will break is a totally erroneous one. The jaw of a heavy old bird will often break if it is held and jerked in October, whilst that of a young bird will as often not do so.

Distribution.-The Red Grouse is indigenous only to the British Islands, and flourishes wherever ling and heath are to be found in quantity. But it is also found on many grass, crowberry, and rush areas in the vicinity of moors even at sea-level. In England it is most plentiful in the northern counties (especially in Yorkshire and Derbyshire), such as Northumberland, Durham, Westmorland, Cumberland, and Lancashire; also, along the Pennine range, and in Cheshire, Shropshire, Staffordshire. Many introductions to various parts of southern and eastern England have been attempted, but these have generally ended in failure. In 1903, Grouse were turned down at Elvedon by Lord Iveagh, and they have bred regularly ever since; now they number about I50 birds (British Birds, September 1908). Wanderers have appeared and been shot as far east as Holkam in Norfolk.

A Red Grouse is reported to have been killed near Tintagel in Cornwall on December 1, Igo6 (J. Clark, 1907, p. 286).

The Red Grouse may be called the typical bird of Yorkshire, being found numerously distributed throughout the moorlands that stretch from the borders of Derbyshire in the south to the north, including Teesdale, and other moors stretching from the Cleveland and Humbleton Hills to the coast as far as Scarborough. In the days of James I., it was the custom to take game either with nets or hawks. Wilson of Broomhead 


\section{The Natural History of British Game Birds}

stated that the first person to shoot Grouse on the wing was a member of his family who died in 1687. In the early days of the muzzle-loader, bags of Grouse were small. Thus we read of a Teesdale keeper being matched to kill forty-three brace of Grouse on August 12, 1840. His performance of the feat was considered remarkable. Three brace per gun was voted as good, and fifty brace in the day unusual for a party in I84I, when driving was instituted. In 1849 on Ryshwork and Edwardes's moors a record bag of 448 Grouse was obtained. ${ }^{1}$ After this, Yorkshire moors improved steadily, for in the year 1872, on Mr. R. H. Rimington-Wilson's moor at Broomhead, 1313 brace were killed in one day by eleven guns. Wemmergill was equally prolific in this famous season. In six days a party of six guns killed $3983 \frac{1}{2}$ brace, whilst no fewer than 17,074 birds were shot in the whole season, of which the late Sir Frederick Milbank claimed 5668. The average bag on this moor for twelve years was 4133 brace. The largest actual bag in one day for Wemmergill was made on August 20, 1872: 1035 brace were shot by six guns, Sir Frederick accounting for 728 birds.

Some doubts having been cast on the remarkable bags of Grouse made on the Wemmergill Moors in 1872 , it will be of interest to quote a letter written by Sir Frederick Milbank on October 17, 1881, which appeared in the Field (August 15, 1908) :-

"Dear Sir,-I have plcasure to give you information concerning some of the shooting. On August 22, 1872, I killed to my own gun on the Wemmergill Moors (which are now in my possession), about fifteen miles due west of Barnard Castle, $73^{\circ}$ grouse, and I may also add, what may appear more extraordinary, nevertheless true, viz., that in three successive drives on that day as I stood in my butt-I5o grouse, I 40 grouse, and Igo grouse. At the latter drive I did it exactly in twenty-three minutes; the other two drives took not more than thirty minutes each. I may also say that five other gentlemen were shooting in other stands, and made very large bags.

"All my birds were laid out in rows at every drive, which is our practice with all shooters, in full view of everybody, and counted before every one of the shooters, keepers, and drivers who may choose to be present, and the birds are again checked off by the man who is in charge of the game cart at a distance (as the moors are too boggy for the cart to get near the butts) as he receives them from the men with ponies and panniers. By this means we know the result of the entire bag before getting home, when the birds are counted over in thc buttery. And I may here mention, on that day the entire bag showed twenty birds more than the shootcrs claimed, accounted for by drivers picking up dead and wounded birds during the drive.

"Altogether we were six shooters; the total bag for the day was 2070 grouse, and one of the gentlemen (Lord Rivers) only arrived on the ground at half-past two o'clock. These are the shooters: F. A. Milbank, Powlett Milbank (my second son), Mark Milbank (my eldest brother), Lord Rivers, Mr. T. Preston (Moreby Hall, York), Mr. Collinson.

"The possibility of my shooting 190 grousc in twenty-three minutes has often been questioned, and people who know nothing about grouse driving say, 'He must have killed five and six at a shot,' and 'It is so many a minute!' I answer that during the whole of that day's shooting, but twice only I killed two birds at one shot. I had three guns and two loaders, and not for one second did I stop or cease shooting, except to allow my loaders to load quick enough. Put up a target the size of a grouse at twenty-five or thirty yards, get three guns, and three loaders, and sce how many shots a minute you can shoot! Well, that is the very way I shot the grouse. The birds never ceased for one second in coming in a continual stream.

\footnotetext{
1 Field, Aug. 17, 1907.
} 
“My entire bag, along with my friends' (never having more than six shooters out at a time), during the season 1872 was 18,23 I grouse!

"As to killing 500 grouse, as you ask, I have very, very often done it. In I87 I was over it one day- 545 grouse; in 1872 three times over 500 ; again in 1876 , on August 22 or 23. 528-all these on the Wemmergill Moors. This year, had the weather been fine instead of wet and windy, I should have had very near 500 birds, if not quite.

"I am not surprised to hear people doubt my performance at Wemmergill, but in a good season no one without seeing them can have the remotest idea of the enormous number of birds. It then only requires the shooter to hold straight to make certain of a very large bag. There are no moors in England or Scotland that can show half the number of birds on them as can Wemmergill.-Yours truly, Fredk. A. Milbank."

On the Bluberhouse Moor the largest bag in 1864 was eighty-five birds, killed over dogs; on August 28, 1872, Lord Walsingham, who now owns this property, had 842 birds, shooting in two batteries for twelve hours. Twenty drivers were employed, in two parties of ten each, for sixteen drives, the guns used being a pair of breechloaders and a pair of muzzle-loaders. This great bag remained unequalled for sixteen years until August 30, 1888, when his lordship broke his previous record and brought down 1070 birds in twenty drives, using four breechloaders, and having two men as loaders, and it is extremely improbable that this remarkable achievement in Grouse driving will ever be emulated. In the year 1904 a record bag for the Broomhead Moors was made by Mr. Rimington-Wilson's party of nine guns-1 374 brace-on August 24. Lord de Grey, whose renown as a game shot is universally known, has had 575 birds to his own gun in one day, as one of a party of seven, shooting on the Marquis of Ripon's moors near Studley Royal.

In 1907 , a poor year, 900 brace were killed in one day at Broomhead, whilst in 1908 $48{ }_{15}$ Grouse were killed on this moor of 4000 acres. Four days of the shooting accounted for $1829,1047,1377$, and 562 Grouse. Thus it will be seen that this remarkable moor produces one Grouse to the acre, and in some seasons two, whilst the best Scotch moors seldom hold more than one Grouse to four acres, places like Cawdor, Moy, \&c., being the exception.

In Wales Grouse are abundant in Denbigh, Flint, and the whole back of the Berwyn range. They are also fairly numerous on the moors of Carnarvon and West Merioneth. Montgomery too is a good county for Grouse. In other suitable situations throughout Wales Grouse are found in smaller numbers. They are not known in Anglesey. Of recent years large bags of Grouse have been made in Wales. On the Ruabon mountains, which my friend Mr. Wynne Corrie rented for ten years, he has made remarkable bags. Of these he sends me the following particulars (see Tables, p. 46), which have not been previously published.

Mr. Wynne Corrie attributes the improvement and continued success of the moor to the head keeper, Allan Brown of Pen-y-Cae, whom he describes as the most skilful manager of Grouse he has known. On Lord Penrhyn's moors about Corwen, comprising an area of 26,000 acres, well over a thousand brace of birds are killed annually, a day's driving often yielding 150 brace. Other good moors in Wales are Glanllyn, Pale, Rug, Rhiwlas, Bodwenni, Creini, Brynbannon, Hirnant, Llymysten, Voelas, Gwydir, and Caerblaidd. 


\section{The Natural History of British Game Birds}

\begin{tabular}{|c|c|c|c|c|c|c|c|c|c|c|c|}
\hline \multicolumn{3}{|c|}{ Season. } & $\begin{array}{l}\text { Brace of } \\
\text { Grouse. }\end{array}$ & $\begin{array}{c}\text { Par. } \\
\text { tridges. }\end{array}$ & $\begin{array}{l}\text { Pheas. } \\
\text { sants. }\end{array}$ & Hares. & $\begin{array}{l}\text { Rah- } \\
\text { bits. }\end{array}$ & $\begin{array}{l}\text { Wood. } \\
\text { cock. }\end{array}$ & Snipe. & Various. & $\begin{array}{l}\text { Total } \\
\text { HEAD. }\end{array}$ \\
\hline 1898 & . & . & $393^{\frac{1}{2}}$ & I & $\ldots$ & I & $\ldots$ & 3 & 2 & I & 795 \\
\hline 1899 & . & . & $\mathbf{1}, \mathbf{1 8 2}$ & $\ldots$ & $\ldots$ & $I$ & $\ldots$ & I & ... & 3 & 2,369 \\
\hline 1900 & . & . & 2,008 & 4 & $\ldots$ & 5 & I & 3 & 5 & $\ldots$ & 4,034 \\
\hline Igor & . & . & $3,34 \mathrm{I}$ & $I$ & $\ldots$ & 4 & I & $\ldots$ & 3 & 9 & 6,700 \\
\hline 1902 & . & . & 2,370 & 10 & $\ldots$ & 2 & $\ldots$ & I & 15 & 2 & 4,770 \\
\hline 1903 & . & . & $\mathrm{I}, 094 \frac{1}{2}$ & $I$ & $I$ & 4 & $\ldots$ & 2 & 6 & I & 2,204 \\
\hline 1904 & . & . & 2,103 & $\ldots$ & $\ldots$ & 3 & 2 & I & 6 & I & 4,219 \\
\hline 1905 & . & . & $2,762 \frac{1}{2}$ & 5 & $\ldots$ & I & $\ldots$ & ... & 13 & 7 & 5,551 \\
\hline 1906 & . & . & $2,150 \frac{1}{2}$ & 6 & $\ldots$ & 8 & $\ldots$ & 7 & 8 & I & 4,331 \\
\hline 1907 & . & . & 1,821 & 4 & $\ldots$ & 3 & 6 & 4 & 16 & 3 & 3,679 \\
\hline 1908 & - & . & 2,224 & I & 2 & 2 & ... & 2 & 27 & 4 & 4,486 \\
\hline \multicolumn{3}{|c|}{ Total for eleven seasons } & $2 \mathrm{I}, 450 \frac{1}{2}$ & 33 & 3 & 34 & 10 & 24 & ror & 32 & 43,138 \\
\hline
\end{tabular}

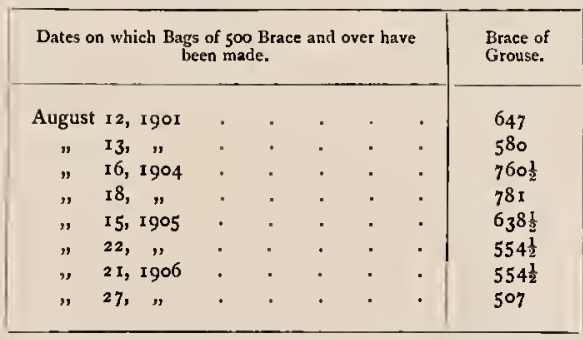

In Ireland Grouse would flourish almost to the extent they do in Scotland, if they had stricter preservation. Vermin, both four-footed and winged, and poachers swarm in almost every district, so that it is well-nigh impossible to raise a large stock even on moors most suitable. Gorse and heather are burnt at any season, generally the nesting time, and in some districts it is as much as a keeper's life is worth to try preservation. In fact, in the west and south of Ireland at the present day, the life of the would-be game-preserver is more unsafe than it would be in any part of Western America. Throughout the island Grouse are very generally distributed all over, not being confined to the high mountains of Wicklow, Donegal, Munster, Connaught, Galway, \&c., where they are most numerous, but also in the flat grass and bog lands of Queen's and King's Counties, Westmeath, Eastern Galway, and Cork. In Connemara and Wicklow, where as many as 100 brace have been killed in one day at Powerscourt, they are successfully preserved; but in Fermanagh, which would be excellent in parts, a friend of mine who tried preserving had both his keepers shot, and he himself repeatedly threatened, until he abandoned the experiment in disgust. In Kerry and Cork, Grouse are fairly numerous and very large.

Grouse are found in abundance in Scotland, wherever the ground is suitable, the protection sufficient, and proper attention is paid to heather-burning. They are distributed over so large an area that it is difficult to do more than individualise the districts and moors where they flourish most. The greater part of Sutherland is devoted to deer, and the same may be said of Ross-shire, although there are many excellent moors, and well arranged on the flanks of deer-forests, where bags of 800 to I000 brace are annually 


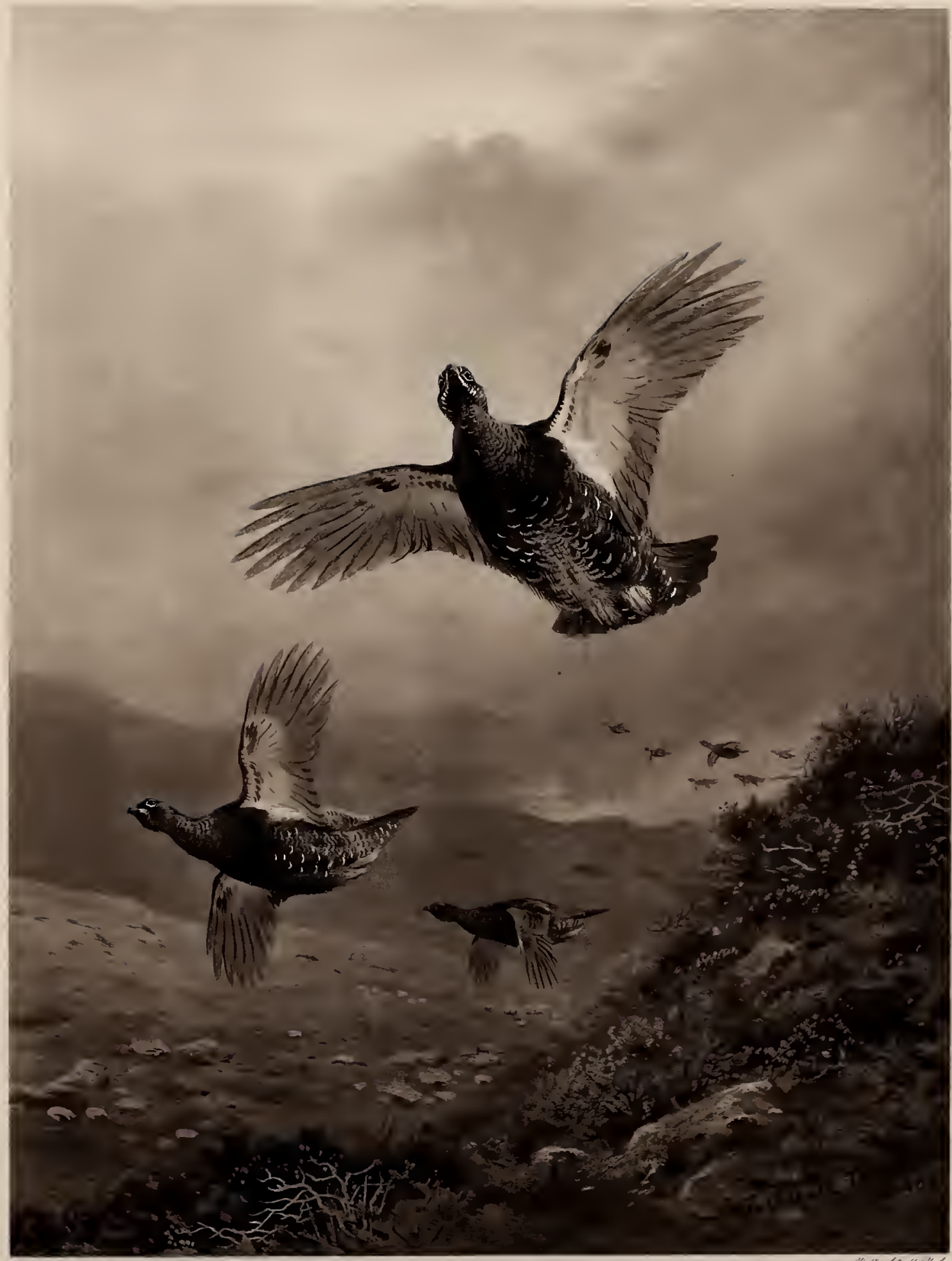

Graves passeng opere hilly yround 



\section{The Red Grouse}

killed. Coming southwards we do not find a first-class area until we enter the district between Glenferness in the east and Loch Ruthven on the west. Between these two points are situated Cawdor, ${ }^{1}$ Moy, and Meallmore, ${ }^{2}$ three of the best moors in Great Britain. I have at one time or another visited most of the Highland moors in Scotland, and I should say that Moy is most suited to Grouse of them all, while Cawdor in Nairnshire and (for their size) Loch Kennard, Drumour, and Grandtully (Perthshire) come a very good second.

In Perthshire a great area is devoted to Grouse, and excellent moors are found on both sides of Loch Tay. On both sides of the Upper Tay are many heavily stocked moors, notably Grandtully, Loch Kennard, Drumour, where 4000 brace have often been killed in a season in Mr. Barclay Field's tenancy, and many others too numerous to mention. There are many fine moors for Grouse in Forfar, Kincardine, and Aberdeen, Wigtown, Ayrshire, Lanarkshire, Ayrshire, and Dumfriesshire, where bags of over 200 brace of Grouse have been killed in one day. One of the prettiest as well as the most productive moors I have seen is Doune (Perthshire), belonging to the Earl of Moray. It is seldom shot, but swarms with Grouse. There are a few good moors for Grouse in Argyll, notably about Inveraray, but most of the ground is given up to deer or to sheep-farming, where heather does not flourish.

In the Lews, Harris, North and South Uist, and Barray, Grouse are still fairly numerous on the low grounds, but too tame to furnish good sport. I think they are slowly dying out in these islands. In Skye they are also found in fair numbers, and in the islands of Rum, Mull, Arran, and Gigha. In the Mull of Kintyre they are abundant.

In the Orkneys, their chief home is the island of Hoy, where the vegetation of the hills is in all respects like the Mainland. On Pomona they occur in small numbers on lowlands near the coasts. They are also common in Rousay and Eday, and a few are found in Burray, Flotta, Fara, Risa Little, and Cava. To Sanday and Westray they are occasional visitors. I have often seen them crossing from Hoy to Pomona, a distance of four miles, and they have been observed flying from Thurso to Hoy, a distance of over eleven miles. I have not noticed that Orkney Grouse are larger than those of the Mainland.

Grouse was introduced to Shetland, at the head of Weisdale Voe, in 1858, and a few pairs bred until 1872 , when they became extinct. There were a few imported in 1882 and 1883 into Yell, and a few pairs probably still exist there. A recent introduction of six hundred birds was made to the Mainland by Colonel Bruce of Sumburgh in Igor. Two were seen at Balta Sound in Unst on 16th November 1902. (British Birds, September 1908.)

Habits.-The species is found in all parts of the islands, where ling and heather flourish, from sea-level up to the rocky tops, where those plants grow. Given a good supply of heather (erica), which can easily be kept in good condition by judicious burning, Grouse will thrive on this low-growing shrub alone; but there are wide areas both in Yorkshire, Scotland, and Ireland where the birds subsist almost entirely on certain grass and rush seeds. Heather of the age of three and four years is their

1 In 1906, 4000 brace were killed on Cawdor.

2 In two days over 900 brace were killed at Meallmore in 1909. 


\section{The Natural History of British Game Birds}

favourite food, and with this they pack their crops every evening, ${ }^{1}$ pulling off the tender shoot with a sharp jerk. In the autumn their love of cereals is too well known to be remarked upon, beyond stating that where corn-fields are to be found in the vicinity of their haunts, coveys and large packs resort every evening to dine. They even frequent these fields when snow-clad, on the chance of picking up a few grains. In summer and autumn they feed largely on all fruits within their reach, such as blueberry, blackberry, cranberry, and cloudberry, whilst the leaves of the mountain willow, blueberry, and the flower of the buttercup are articles of diet. In hard weather they will resort to the trees, like blackgame, and I have seen immense packs feeding on the fruit of thorns and rowans at low levels, especially where the snow has drifted. I think they will even eat birch buds at this season, although I have never seen them in their crops. A good supply of grit is very necessary to their well-being, as well as an abundance of fresh water.

"In very severe winters, when there is a great depth of snow, grouse are obliged to leave the high tops for the cultivated lowlands, and at these periods the moors are quite deserted. While the snow is soft they are able to tunnel into it and so get at their food, but when a thaw is succeeded by rain and followed by frost the surface of the snow becomes glazed with ice, and the birds are unable to make a way through owing to the formation of their claws, which, admirably suited as they are for walking on the soft surface, are not adapted for burrowing through frozen snow.

"In the years I 886 and I 895 huge packs of grouse were compelled to resort to the low country, where they fed on corn, turnip leaves, or buds and hedgerow fruits; many were observed perched on hedges and the lower branches of trees, and some even were noticed on the seashore and in the vicinity of large towns. On the breaking up of the storm, birds gradually work back to their original ground, although many seek fresh quarters, thereby providing a much-needed change of blood, and as those that are weak or diseased doubtless succumb to the rigour of the weather, it follows that the remainder constitute a strong and healthy breeding stock, the result being to the ultimate advantage of the supply on the moors.

"Grouse are very fond of picking up pieces of grit, which is in reality necessary to all game birds, though until recently it was not generally known they ate peat, but in North Yorkshire they have been observed to do so. In the mornings they eject a pasty mass of indigestible matter, samples of which have been examined and discovered to consist of grit and vegetable substances, leaves of plants, chiefly ling, formed into a pulp." z

Although the principal food of the Red Grouse is the young shoots of the heather or ling (Calluna vulgaris) and the common heaths (Evica tetralix and Evica cinerea), it is wrong to suppose that the species cannot exist without them. As a matter of fact there are many moors in Cheshire, Yorkshire, Lancashire, Wigtown, Ayrshire, Argyllshire, Kinross, Perth, \&c., where Grouse are abundant and where heather is quite unknown or only occurs in patches. Instead of ling and heath there is a plant which closely resembles both these species, and whose purply black fruit, and possibly the shoots, afford an agreeable food to both Grouse and ptarmigan. This is the common crowberry (Empetrum nignum), a dwarf shrub, in no way related botanically to the heaths, but found in abundance in sub-arctic lands from the British Isles to Kamtschatka, and from Alaska to Labrador and Newfoundland. The foliage of the crowberry is

1 Grouse pick about a little in the early morning, but do not eat much beyond grit and a few shoots of heather. In the corn season they will stop all night on the fields, eating a little at daybreak.

2 Field, Aug. 17, 1907. 


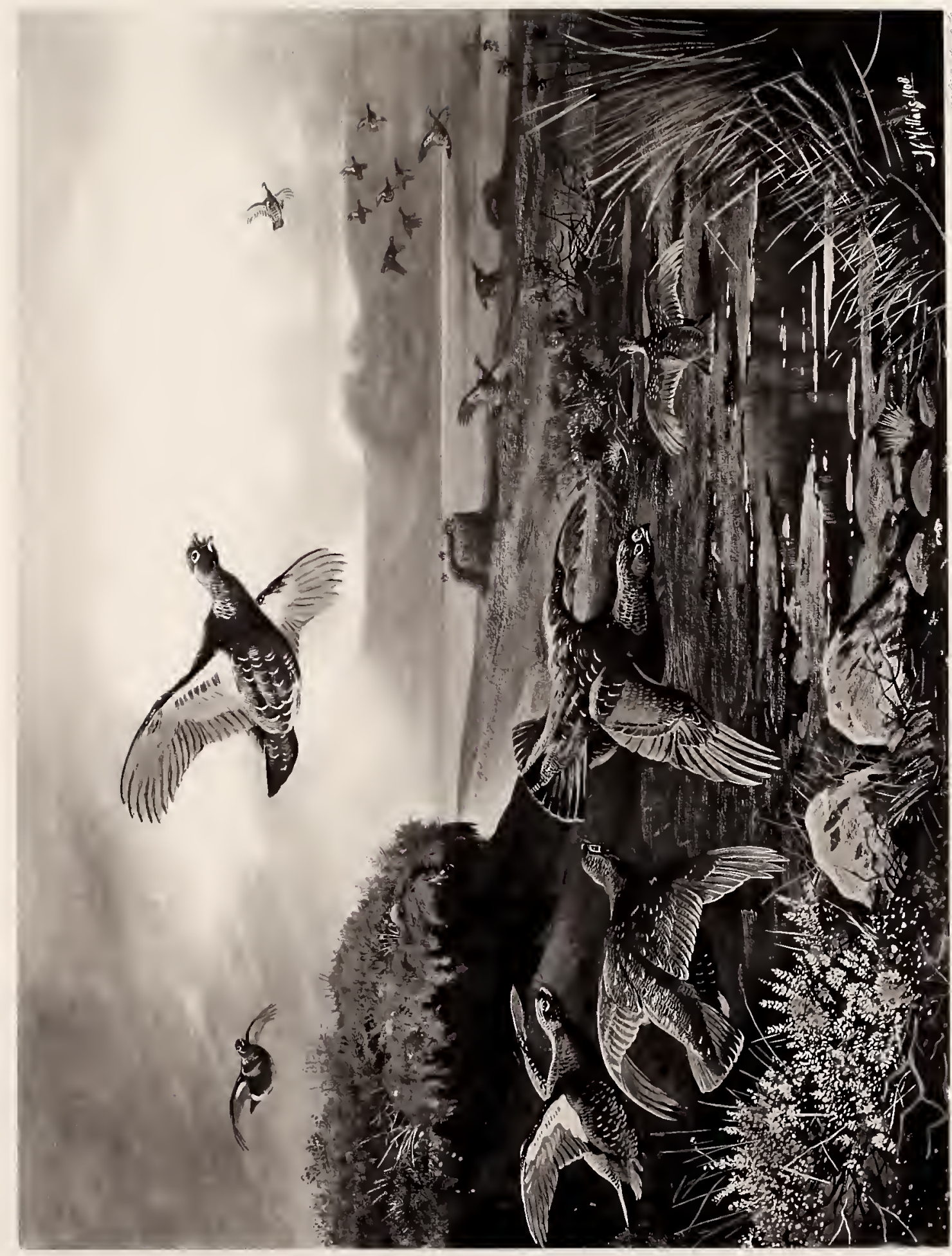

츨 



\section{The Red Grouse}

very like that of the heather, but the flowers are borne in April or May instead of in July and August.

During late autumn Grouse are much influenced by the weather. If it is sunny and mild, small packs are formed consisting of mixed sexes, broods of the year, or females alone. Sometimes old cocks pack together, but till this season they are often found alone or in twos and threes, sitting about on points of vantage on the hillsides and about the tops. In late autumn the females are usually much wilder than the males, a curious contrast to blackgame and capercaillie. If a "kite" is used at this season hardly any females will be killed. They fly away as soon as they see the kite and the guns, whilst the old cocks sit closely. Broken weather in November usually drives the smaller packs together on the sheltered sides of hills, and so immense flocks of Grouse are seen during and after storms. Continuous snowstorms will force the whole stock from the higher hills to the lowlands. I remember once driving through Moy after such a storm, and seeing at least 3000 Grouse scattered over one small area, close to the roadsides. Such privations-primarily due to want of food-cause Grouse to be migratory, and few sportsmen understand how very migratory Grouse are under such circumstances. They leave a fine stock of birds on a moor in the autumn, and next season lament the scarcity of birds; the whole stock has, perhaps in one day, flown from Perthshire into Argyllshire, where the winters are milder and the snow does not lie. My friend Mr. John Nix has informed me that on his moor near Inveraray a very moderate stock has been left after shooting, and that almost every year about Christmas time immense packs of Grouse come in from the east from over the hills and overstock the ground. I believe that during exceptional storms from the east Grouse will fly half-way across Scotland, in order to get food and shelter.'

The winter of $1884-85$ was one of the severest experienced in Northumberland. There was a fall of snow, a partial thaw, and then a severe frost, which kept the country ice-bound for three months. All food was frozen, and grit was unobtainable. The Grouse soon accepted the conditions before it was too late and gathered in thousands on the heights of Simondside, and from thence passed in immense packs across the Coquet to the sheltered moors about Cragside. It was the opinion of residents that had it not been for this timely emigration, and the shelter and food of Lord Armstrong's moors, nearly the whole stock of Grouse in Northumberland would have been destroyed. As it was, 1885 was quite an average season; the most weakened birds being only a little later than usual at their nests.

The causes of migration are obviously lack of food, drought, and snow. It must not, however, be supposed that snow, even heavy snow, will always cause Grouse to leave their accustomed habitat, for snow often brings with it high winds, and this, the terror of the farmer, is of benefit to Grouse, because of the bare places it leaves in exposed situations-on these the packs can gather and feed in the short winter day;

I For other instances of the migration of Grouse, read Harvie-Brown, Fauna of the Moray Basin (ii. p. 153), who says: "Grouse will migrate miles, even across sea, to search for good heather and healthy conditions." Mr. R. M. Barrington, in his Report on the Migration of Birds at Irish Lighthouses, mentions (p. 185 ) three instances of Grouse seen at light stations, in 1883,1884 , and 1894 , on islands where they are not resident. See also Proceedings of the Glasgow Nat. Fist. Sociefy for 1879, p. 167; Clarke and Roebuck, Forishire Vertebrata, p. 62; Nelson, Birds of Yorkshire (ii. p. 512); and a correspondence on the subject in the Zoologist, 1886, p. 107, and 1895 , pp. 21,69 , 108.-Field, Dec. 19, 1908. 
but it is the fall of snow followed by a thaw and then by hard frost which causes emigration with late Grouse for great distances to where the conditions of life are possible. The passage from high to low ground in winter can hardly be called a migration, as most of the birds return in spring, but after a big winter movement extending to a great distance it is doubtful if many of the wanderers reseek their place of birth. Local movements are common in Perthshire and Strathspey. During some winters certain low grounds are swarming with birds, which rapidly eat up all the food, and take the first opportunity to return to the high hills where fresh food is more easily to be found. In consequence, it is found that after the breeding season the high beats are much better stocked than the lower ones.

Again, local migration may be caused by drought, for water is very essential to Grouse, and they will desert a moor very soon that does not hold a good supply. All the best moors in Scotland are well watered, and owners of dry moors will do well to create artificial supplies if they wish to hold their stock.

All men who think, and have had experience as well, must see that the overstocking of moors is the main cause of the Grouse disease. It is impossible to keep a great number of birds or animals in good health if the condition of their food supply is insufficient. No moor can carry more than a certain number of Grouse, and when this number is exceeded disease, due to an improper diet, is bound to begin, and then rapidly to spread.

As I have often stated, volumes may be written and newspapers flooded with opinions as to how to improve Scottish deer and Grouse, but nothing will be done (except locally) as long as the individual selfishness of man exists, and that will be to the end of the chapter. There are too many conflicting interests to be studied. A landlord who does not know the fluctuating conditions of his moor says to his tenant, "You must not shoot more than a certain number of brace of Grouse." That is doubtless correct for a certain number of seasons. But the tenant, if an intelligent man, has meanwhile been improving the moor every year, and one year he obtains a large stock of birds, larger than the moor can hold. He is still restricted to his 500 brace, let us say, when properly he should kill 1500 brace. The landlord, however, says No, only 500 brace are to be shot; and so when the winter comes those extra thousand or two of Grouse must be forced to live on old worn-out heather and other unsuitable food, or starve. Thus when spring comes this moor, and probably the adjoining one, where similar conditions have prevailed, will be a prey to disease. It seems true that the only preventive to the evil is a wholesale slaughter in bumper years. Every Grouse that can be killed should be shot before December Ioth, and then both the tenant and the landlord would ultimately benefit.

The management of Grouse moors is now so well understood that little need be said on the subject. In a really well-kept moor there should be no heather over a foot high, except in a few places for shelter; and it is well to remember that when once the moor is brought into good condition only small patches of heather a few yards square ought to be burned. This forms numerous and scattered feeding grounds, especially for young birds, whilst, at first, these bare places are excellent spots where they may sun and dry themselves, a very important point for half-grown Grouse. Plenty of 


\section{The Red Grouse}

young heather is the secret of good Grouse management. All dead animals, too, which may contaminate a water-supply, should be removed from a moor. A few remarks on keeping the moor in good condition are given in the Field, from which I quote the following, as it is much to the point:-

"Overstocking, with the resultant scarcity of food, stagnant water, and the attendant indigestible character of the heather when the young shoots are nipped by late spring frosts, are all detrimental to a healthy stock. No doubt a great deal might bc done to prcvent disease, or, at all events, to minimise its effects, by keeping down the stock of birds within reasonable bounds; by killing off some of the old cocks, which are most detrimental to the well-being of a moor; by endeavouring to kill and burn any 'bad' birds, as those which are pricked or are suffering from tape-worm or any other illncss are termed, and which must be predisposed to disease; by improving the heather with judicious burning; by reducing thc stock of shcep on the moor; and by a good system of drainage. On too many moors the vermin are not sufficiently kept down, and the many enemies the grouse has to contend against must exact a heavy toll of thcir numbers. In the spring, rooks, jackdaws, and hoodie-crows destroy many eggs, especially on the low-lying moors, whilst foxes, weasels, and stoats commit many a cold-blooded murder of the sitting hens. Although hawks, harriers, and falcons are included in the keeper's 'black list,' the writcr is of opinion that these birds of prey are not altogether undesirable occupants of a moor ; they kill off many sick birds, and thcir mission in the system of nature is a decidedly useful one. No good sportsman ought to regret that the use of that abominablc instrument of torture the pole-trap, which has been the means of destroying many harmless birds, such as cuckoos and nightjars, is now forbidden by statutc.

"A good many nests of grousc, and also young poults, are killed by the sheep-dogs used for rounding up thc sheep that are 'stinted' or 'gaited' on the moors, and there is little doubt that sheep are a check to any great increase in the stock of birds, as both feed on the same food; the sheep, owing to the formation of its jaw, pulling up the young heather. More hcather is now burnt, in most cases judiciously, than was formerly the custom, though even now many kecpers are too conscrvative in this respect, and do not burn sufficiently. The burning should be done in patches, so that there may always be a sufficient supply of fresh shoots of heather to serve as food for the young birds, and within easy distance of covert, to which they can resort if danger threatens, or in case of stormy and severe weather. There is still an Act in force for regulating the seasons when heather shall be burnt, but its provisions are not strictly enforced in Yorkshire. In former times the illegal burning of heather was looked on as a serious offence, being punishable with a month's imprisonment and hard labour, though it is possible that other intercsts than those of the grouseshooter were considered." 1

The so-called Grouse disease was known as long ago as I847, when Charles St. John recorded his impressions. It was then rife in Inverness-shire, and many subsequent writers on sport and natural history have referred to it, but from an unscientific point of view. Captain Chapman tells us that on Bowes Moor, in 1873, "the birds were literally carted off in thousands, and not a gun fired there that year;" whilst all who have had experience of Scottish shooting have had reason to lament its frequent recurrence. In 1890 I was invited one day by Mr. Barclay Field to help to kill off the diseased stock on Drumour. We shot over 200 brace of Grouse, all of which were suffering from nematode worms; the feathers of the legs had gone, and the whole plumage of the birds presented a rusty, dull appearance. At the end of the day a pile of heather was raised and the whole 400 birds burnt, a melancholy spectacle.

The first study of the Grouse disease was made in 1868 by Dr. Young of Glasgow, who dissected certain diseased Grouse and found that the small intestine was plugged 


\section{2 \\ The Natural History of British Game Birds}

with a mass of tape-worms. He advanced the view that the disease was in no way due to the presence of entozoa, but that the peritoneal inflammation was the cause of death. His conclusions are summed up in these words: "The mortality is, in fact, due to malnutrition, to a cachectic state transmitted from parent to offspring, and predisposing the young to suffer from influences such as severity of seasons or temporary scarcity of food, which under other circumstances they would have resisted successfully."

Thus we see that the tape-worm theory of death was rejected, and that Dr. Young expresses the view that the Grouse died of a disease of an epidemic character.

Mr. H. Hammond Smith in the Field (Aug. 15, I908) gives a very able summary of recent writings on the subject, prior to the report of the Grouse Disease Inquiry Committee, and from which I extract the following notes:-

"The subject of grouse disease will always be associated with the name of Dr. Spencer Cobbold, on account of the important work carried out by him in 1872 on the entozoal parasites of grouse. In 1873 , besides his contribution to the Field of that year, he published a brochure on grouse diseasc, in which he attributed the cause of the malady to a small nematode worm, found principally in the blind cæca of the birds, and called by him Strongylus pergracilis. This worm was found in large numbers in the specimens examined by him, which also presented similar symptoms to thosc which died of grouse disease, and were described by St. John in 1847 . This parasitic theory of Dr. Cobbold's must not be confounded with the opinion of Dr. Young, who in 1868 rejected the parasitic theory of the origin of grouse disease. Dr. Young referred to tapeworms as cntozoal parasites, but Dr. Cobbold founded his theory on the presence of the round worm, or strongyle, which was apparently not observed by Dr. Young.

"In the Zoologist for November I882, Mr J. A. Harvie-Brown published a paper in which he attributed grouse disease to over-preserving, overstocking, the indiscriminate destruction of vermin, such as the peregrine falcon, \&c., the too rapid burning of heather, the eating by the birds of heather which had been frosted, and a wholly artificial system of 'grouse farming.' But unfortunately he admits that he writes without statistics. On the one hand, he states that disease is never seen on the deer forests, where grouse lead a natural, not an artificial, life, whilc on the other hand it is seen on overstocked moors, where there may be 'fifty birds to the acre,' although on this point again he had no statistics, and in reality nothing like it exists.

"The danger of overstocking is really a remote one on well-kept moors. Look at the large bags obtained on the Rimington moors, where disease is practically unknown. A moor that at the end of the season has produced one brace of grouse to every ten acres is a good moor, and that cannot be called overstocking.

"Mr. D. G. Macdonald, in his book on grouse disease ( $188_{3}$ ), gives a very interesting account of disease as observed on two moors in the north of Scotland, and also refers to an article in Bell's Life of Jine I6, I86r, on discase among the grouse of British Columbia and Vancouver Island. The Indians of those parts state that when the winter has been more than commonly severe and the spring cold, the leaves and buds of the trees and shrubs on which the grouse feed lack the nutrition necessary for the health of the birds, and consequently a discase is gcrminated among them to which they speedily succumb. He also cites two instances in Scotland in 1867, one of a moor exposed to the cold wind of spring after a severe winter; the heather was dry and sapless, and during that season there was a great mortality among the grouse, while on a moor near, in the same county, but which was very sheltered from the cold spring winds, the grouse season was a very good one. He also points out that in the birds examined the liver was black and soft. Hc further mentions a very important fact, namely, that in 1867 many of the birds picked up were plump and in excellent plumage, whereas in former years the birds found dead were characterised by dull, disordercd plumage and attenuated bodies. He evidently thought there were two forms of disease. Mr. Macdonald also refers to the periodicity of the disease; according to his statement disease was noted in I809, I 824, I 835, 1847, I 856, I 865, and 1870 . He goes on to say it invariably bcgan on the moors furthest south, and travelled northward county after county. 


\section{The Red Grouse}

"Mr. Thomas Speedy, in his Sport in the Highlands and Lorvlands, also mentions that in 1867 the disease made its appearance in two different forms. At first the birds were 'draggled,' wasted, and emaciated, and bare about the legs, showing that they were suffering from a long-continued and fatal disease. Later in the scason the birds were found dead in beautiful plumage, and with wellfeathered legs, and in excellent condition. These birds were suffering from intense inflammation of the bowels, and immense quantities of 'strongles' were seen. The disease made its appearance again in 1873 , and again quantities of tape-worms and 'strongles' were found in the affected birds. But Mr. Speedy did not attribute the disease to parasites; nor does he agree with other theories as to the origin of the disease, such as the eating of grain by grouse, or eating frosted heather, or from overstocking. On the other hand, he, like others, deprccates the disturbance of the balance of nature by the wholesale destruction of vermin, pointing out that these are always more likely to prey upon diseased and weak birds than upon healthy and vigorous ones, and so would do good rather than harm. At the same time, he expresses his belief in atmospheric influenccs, and quotes in support of his theory Dr. Farquharson, Mr. M'Haffie, and also 'Dr. Andrew Wilson, lecturer on zoology and comparative anatomy, who tells us "he does not believe in the parasitic theory, but in some lesion analogous to the epidemic theory." '

"This brings us to the admirable work donc by Professor Klein, at the instance of the editor of the Field, in 1887 , in the investigation of this disease, and confirming the theory advanced by Dr. Andrew Wilson. In a paper in the Zoologist of October I892, Mr. J. E. Harting, in reviewing the work of Professor Klein, drew attention to the fact that in 1874 Dr. Farquharson and Dr. Andrew Wilson had expressed their belief that grouse disease was an epidemic infectious fever. Professor Klein's investigations, carefully carried out, both on the moor and in the laboratory, led him to conclude that grouse disease was due to a specific bacillus. In his work he describes all the symptoms most carefully, and it is curious to note that his description of the liver agrees with that of St. John in 1847 , though, of course, described in other language. In his work on grouse disease Professor Klein describes all the characters of the bacillus which he found in specimens of grouse sent to him for cxamination, and also his inoculation and other experiments with other birds.

"One of the most recent contributions on the subject of grouse disease is that by Mr. A. E. Shipley, F.R.S., in the Encyclopadia of Sport, p. 491. He refers to the work done by Dr. Cobbold and Professor Klein, and, like Dr. Cobbold, says that the presence of the Strongylus pergracilis is probably the cause of more disturbance to the health of the grouse than the presence of the tape-worm Tania calva found by Baird.

"These references-and thcy are necessarily brief-show considerable divergence in the views of those in a position to offer opinions upon the origin of grouse disease. These opinions differ almost as much now as they did when first published, and extend from the view of overstocking, \&c., to the belief in an epidemic due to the action of a specific bacillus."

Mr. W. A. Tegetmeier has repeatedly given reports on the condition of birds sent to the Field Office, and he has been impressed with the evidence of some form of enteritis so common among pheasants, partridges, and fowls, and also that Grouse which have died during visitations of the epidemic have exhibited such widely dissimilar degrees of congestion of the lungs and intestines. Sixteen years ago Dr. Klein clearly demonstrated that the enteritis of fowls is distinct from the disease of Grouse, but the study of the subject has advanced greatly since that time, so that we await the report of the Grouse Disease Inquiry Committee (now sitting) with considerable interest.

In 1907 Dr. Sambon discovered a new filarial larva found in the blood of a Red Grouse sent to him for examination, of which the following is the Field report (Sept. 21, 1907) :-

"This bird, sent to us from High Ardwall, Anworth, proved a most interesting case of multiple parasitism. From amongst the feathers were collected numerous lice (Mallopliaga) of two kinds, 


\section{The Natural History of British Game Birds}

Goniodes tetraonis and Nirmus cameratus. In the ileum were found five specimens of the larger and more common tape-worm of grouse, Davainea calva; in the duodenum numerous specimens of the minute threadlike cestode Hymenolepis tetraonis. The cæca were literally teeming with millions of the extremely small and slender round worm Strongylus pergracilis. The blood contained, in addition to putrefactive bacteria and to the larva of Filaria smithi already mentioned, large numbers of Leucocytozoon lovati, a protozoal organism quite recently discovered by Drs. Seligmann and Sambon in the red grouse.

"The bird in question was picked up alive by a retriever, and sent to us as suffering from 'grouse disease.' It was somewhat emaciated; the plumage was dull, the feather stockings were partly rubbed off, the combs were pale. The lungs showed very slight, if any, congestion, the liver was dark round the edges and rather softer than normal, the spleen seemed normal, the preventriculus was somewhat congested, but the caca and intestines were normal in colour and appearance. The bird was a cock, and the testicles were fully developed. This grouse was evidently dying of an acute disease. The tape-worms it harboured were certainly not the cause. Both Davainea calva and Hymenolepis tetraonis may be found in far greater numbers in apparently healthy birds. The same may be said of Strongylus pergracilis, though Cobbold, who discovered this entozoon, believed it to be the cause of the grouse epizootic he investigated in 1872 . Like Davainea calva, Strongylus pergracilis is found almost in every bird. In the present instance, though extremely abundant, it appeared to have caused no appreciable lesion. The cæca seemed perfectly normal. As to the microfilariz, they have no pathogenic importance.

"Dr. Sambon is inclined to consider the Leucocytozoon as the most probable cause of the bird's condition. Since the discovery of this parasite by Dr. Seligmann and himself, he has found it in three other birds, including the one here mentioned. The leucocytozoa have a very complicated and as yet very imperfectly understood life history. Like the malaria parasites of man, they present an alternation of generations, together with a change of hosts. The 'vegetative' or asexual cycle of Leucocytozoon lovati occurs in the blood and bone marrow of the grouse; the sexual cycle, according to Sambon, is probably spent in the body of the grouse fly (Omithonyia lagopodis), a parasitic fly of the family Hippoboscida, which appears to be strictly limited to the red grouse."

The Grouse Disease Committee issued an interim report in the autumn of 1908. Their observers stated that during 1905, 1906, and 1907, no instances of death from the acute pneumonia form had been noticed. All birds sent to them in 1908 died as the result of internal parasites.

The usual length of flight is about half a mile to a mile. When about to alight Grouse look about to see if any of their kindred are to be seen, and call to them, and if the survey is satisfactory, they quickly swoop round and pitch beside them. Single males nearly always give a little rise in the air at the last moment and flutter to the ground, uttering their cheery cry. The point of alighting is usually a rising knob from which a good view to the front may be obtained. Here they sit and watch for a few minutes, and if they see a move in the "butts" ahead they will generally break back on being flushed. I have known Grouse come into a shooter's butt and settle round his legs. Scared by a hawk a covey of Grouse came into my brother's butt during a drive in Aberdeenshire, and refused to leave. As a rule Grouse on flat moors or sloping hillsides go straight ahead and are not difficult birds to shoot, but when curling through a pass and "falling" into the next valley they are among the most difficult birds to hit in existence. I never think of this without calling to mind a wholesome anti-conceit tonic I received one day at a certain pass at Corriemuckloch in Perthshire. In the previous drive I had only missed one shot, getting twenty-two birds, and was feeling just as a man does under such circumstances. In the next 
drive I was in the best place at the "neck," and fired thirty-eight cartridges, picking up two birds. My host, Mr. Julius Reiss, endeavoured to cheer me by saying that no one ever killed any Grouse at that particular drive, but I was miserable and humbled. Next year I took Archie Wortley to the same drive, and was quite cheered to see him kill exactly three birds, with an expenditure of about forty cartridges. I have heard shooters say that a driven Grouse is an easier bird to kill than a driven partridge, and so it is generally, but at times the Grouse is far more difficult, and whenever I hear a Norfolk shooter, who has been to Scotland once or twice, discussing the comparison, I wish I could place him at the "neck" at Corriemuckloch, and nyself sit by and look on.

During the actual love-chase, it is common to see a cock diving and twisting after a hen with almost the persistence and wing power of a mallard-drake during the courting season. I have seen a male pursue a female up and down a hillside for a mile, and then back again over the same ground, before she alighted at last in exhaustion. The twists and turns of both sexes in the air are remarkably agile, so different from the straight ahead flight of the driven bird. The flight, as a rule, is a direct rise from the ground of twenty feet, when flushed close at hand. The cock always crows loudly at all seasons, but the female only in spring when mating, or in summer and autumn when she calls her young to follow. ${ }^{1}$ When rising in packs at a distance from the gunner, Grouse often fly close to the ground, especially when facing a wind, and take every advantage of natural inequalities to break the wind resistance. They prefer to fly down wind, and if repeatedly pressed up wind, will sooner or later break back, unless skilfully "flanked." The speed of flight varies from twenty to forty miles an hour, but when pressed by fear or assisted by a gale they can go at sixty miles an hour. I once witnessed a very interesting example of the speed and staying power of four Grouse. During a snowstorm in October I900, I was slithering down a marshy hill on the tops above Braulen in Ross-shire. A glorious assortment of stags, one a splendid royal, which I afterwards killed, were scattered beneath us, and the excitement was intense in spite of the wetness of that part of the human person one generally likes to keep dry. The last approach was being made when the stalker Macdonnel gave an exclamation and pointed across the valley to a peregrine falcon, which had just made an unsuccessful stoop at four Grouse. On finding itself behind the Grouse, the falcon with a few rapid strokes of the wings endeavoured to make up on its mistake, and nearly succeeded in seizing one of the Grouse. Then ensued a remarkable chase, which we could clearly see for a space of two and a half miles. Pursuer and pursued came right round the vast amphitheatre and passed us within fifty yards, going down wind at a speed I have seldom seen equalled by Grouse. We could not, unfortunately, witness the termination of the contest, but during the last half mile, when the birds were still in view, the peregrine did not seem to gain or lose an inch. I did not think a falcon would be so persistent, as this genus (not hawks) are usually soon discouraged after a "stoop" that fails, but I have no doubt that that bird got its quarry.

Strictly speaking, such monogamous birds as Grouse, ptarmigan, and partridges do not hold a "lek," or resort to any fixed spot as black grouse and capercaillie do, and 


\section{The Natural History of British Game Birds}

yet if we watch them very closely in the initial stages of their courtship, something very like an assemblage for general fighting and mating takes place. As fine weather occurs, even in early January, Grouse break away from the big packs and resort to coveys again. It requires but one week of really fine and mild weather at this season for these coveys to commence the business of fighting and pairing. The males fight much after the manner of the blackcocks, but do not lift the tail so high. They endeavour to strike each other with the bill, especially on the top of the head, springing up into the air and hitting downwards. On the ground they will seize each other anywhere about the neck or head, and if one gets a hold it scratches, worries, and beats the other with the wings, making a loud noise in so doing. When one is victorious it flies up into the air, uttering its loud "Kok-er-a-kok-kok-kok-go-bak-gobak-gobak," as a pæan of victory and challenge. Each male that has succeeded in appropriating a female separates her to a distance of forty to a hundred yards from what we may call a central point of the open ground which they have chosen as a mating place. Here he stands upright, frequently calling " "uk-uk-uk," or "bec-bec-bec," lowering his wings, erecting his comb, and quivering the tail. At such times his beautiful plumage shines, and he looks a very handsome bird. The female meanwhile crouches down beside him, and remains immovable until another cock Grouse accepts the challenge of the male and comes to do battle. Whilst the males are fighting, she runs round and round the pair with great swiftness, sometimes uttering a low clucking note, and at once settles herself at the side of the victor. Her affections seem to go solely to the strongest male.

During the mating season the female Grouse has a distinct call of her own, of which I do not see reference made in any book on Natural History. It is fairly loud, like the words "ee-ack-ee-ack." She repeats it from the ground when she desires to call the male, or is suddenly frightened. I have known poachers to sit in a bush and imitate the call, when the cocks will come round and become much excited. They are then easily killed with the .22 rifle.

When cock Grouse are fighting the contest is fairly vicious as long as it lasts; but it is usually not protracted, one or other soon giving way. The vanquished male flies off, pursued by the victor, and so the fight is unlike that of capercaillie and blackcocks, extended over a considerable area. Often the victor is attacked again, and routed by some male that he has chased away. Contests in which more than two males take part are unusual, but $I$ have seen four cocks all in a mêlée together, fighting desperately, and so closely engaged that I could nearly touch them. Not being so well armed as the larger game birds, Grouse seldom inflict serious injury to one another, but they often become blinded temporarily from wounds about the eyes.

In the covey there are always a few old cocks, as well as passing troubadours which come and settle amongst the pairing and fighting birds, that are elements of chronic disturbance and mischief. They will not dwell in peace with their neighbours, even when they have got a good wife, their one object being to make fresh conquests and to unsettle or drive off the young males that are already paired. March may be said to be the general month of mating, but all through this month, as well as in April

1 In spring the call note is more loud and defiant than at other seasons. Many males cry in different keys, some as though tenor, baritone, and bass. 


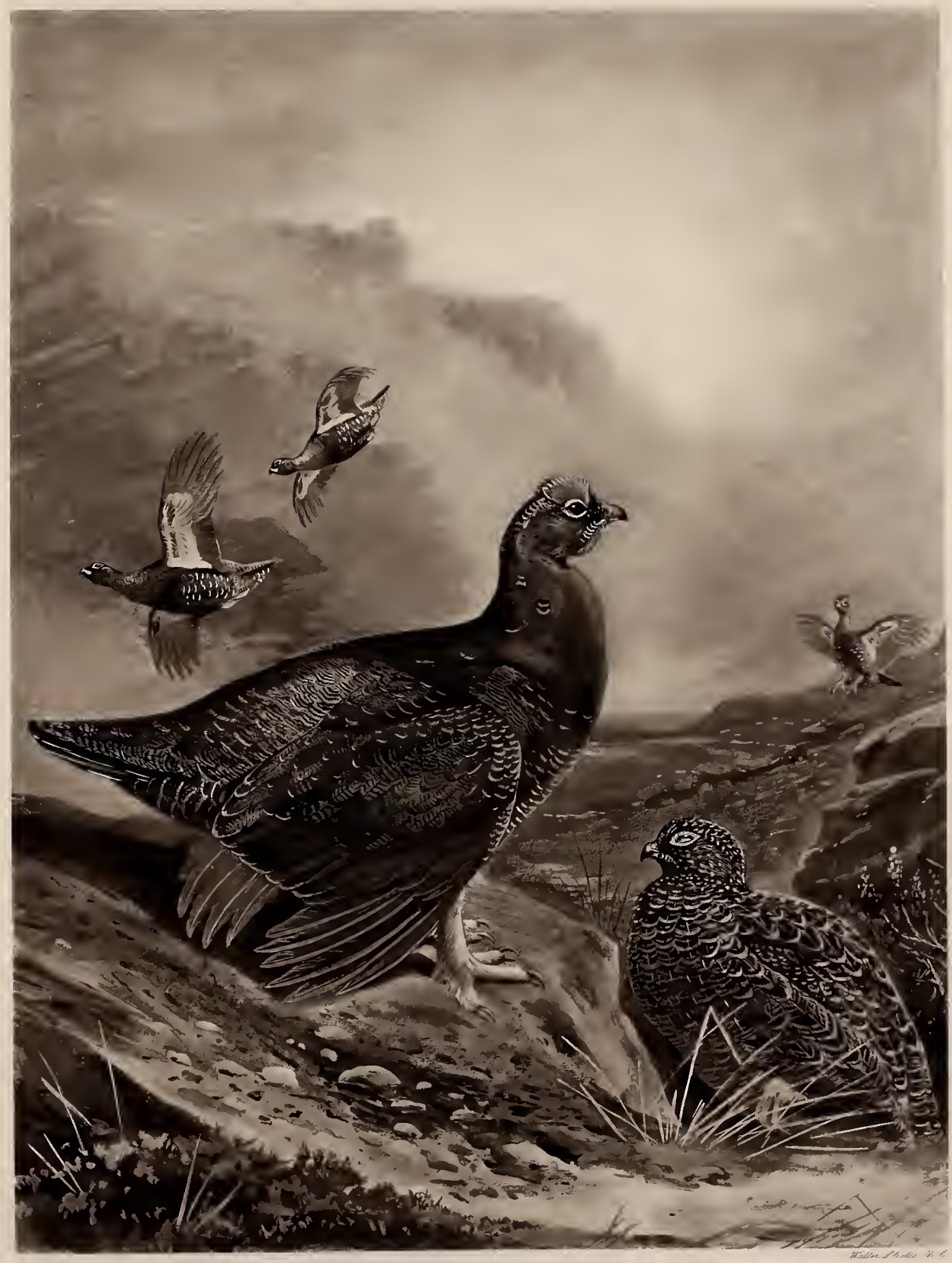

$$
\text { 'Povestatieg of ther Gomerse }
$$





\section{The Red Grouse}

and well into May, these mischievous old cocks roam to and fro creating work for the divorce courts. Besides careful heather-burning, nothing has so improved Grouse as the practice of driving, for it diminishes the number of these co-respondents and gives the younger males a chance in the spring-time. Kiting in October is also an excellent method of killing old cocks, or walking quietly by oneself round the tops and catching these old fellows when alone or in pairs. In April I have been watching Grouse on a hillside, and seen the same hen appropriated by four different cocks in as many minutes, and then abandoned altogether. Females thus treated will not nest. They become unsettled and unfit for duties as a mother. I would strongly advocate shooting old blackcocks at the playing-ground in April一that is to say, by experienced persons; but to shoot old cock Grouse at this season would not do for many reasons. The remedy is to keep the moor in good condition at the proper time. Old cocks that will not pair, but do nothing but worry others, are the worst kind of vermin, and indirectly do great damage, as any observant keeper can testify.

Grouse have been known to nest as early as February, which proves that in certain seasons they will pair at a very early date; but I have never seen the nest before the end of April, and even that is early. Full clutches are generally laid the second week of May. At this date several blizzards of snow often occur in the high ground, as they did in 1906 in the third week in May, and the birds sit so close that many perish on their nests. During this month a keeper told me he had found over twenty hens dead on their eggs, and yet this and adjoining moors did remarkably well in August, since most of the birds which were not actually brooding made fresh nests.

Mr. Seton Gordon thus writes ${ }^{1}$ on the same topic:-

"Their nesting season is comparatively early, considering the storms they are subject to on the mountains, and often a later snowstorm than usual plays havoc with their nests. Especially was this the case during the spring of 1906 , when about the third week of May a very severe blizzard visited nearly the whole of Scotland. In places drifts of great depth were rapidly formed, and in one district, after the storm, a keeper found no less than nine hen grouse dead on their nests during a single morning's walk on the moors. In another case a keeper told me that a certain grouse had just finished laying, but had not commenced to brood, when the storm came on and covered nest and eggs with many inches of snow. The hen bird, however, remained near by for over a week, until the eggs once more appeared from beneath the snow, when she took up the duties of incubation and hatched out her brood as if nothing had happened. However, many of the birds were not so fortunate, and in several instances I saw a pair of old birds with only one or two young ones, and in some cases none at all. Yet the most extraordinary thing about it was that the shooting season was the most successful for years, and on a moor which suffered more than any bags of 140 brace and more were got for days on end. The only explanation seems to be that in the majority of cases the birds had only just commenced to brood, and so were able to lay a second clutch within a short time, for as late as the end of August I came upon young birds still weak on the wing. A shepherd informed me that at the beginning of that month he had flushed a hen from her nest so weak that she was unable to fly, having probably sat on her eggs for two months at least, as most likely these had been rendered infertile by the May snowstorm."

The nest is a slight hollow in the ground, lined with moss and grass, and well sheltered by heather and tufts of grass. The eggs, cream and buff-spotted and blotched

\footnotetext{
1 Country Life, May $\times 7,1907$.
} 


\section{$5^{8}$ The Natural History of British Game Birds}

with rich red-brown, are from seven to twelve in number, measuring 1.75 by 1.32 inches.

Some observers are of opinion that frost is most injurious to Grouse eggs, but I do not think that $10^{\circ}$ to $15^{\circ}$ of frost will hurt them at all, although we know that such a temperature would mean ruin to pheasants' eggs. Some of the best Grouse seasons of late years have followed very cold springs, when the eggs had to withstand such cold as above mentioned before the birds began to sit. I have heard of instances where a greyhen has laid eggs in the nest of a Grouse.

The young run swiftly almost as soon as they are hatched, and are very carefully attended by the mother, whilst the cock keeps guard on adjoining hillocks and gives notice of the approach of man or vermin in a creditable manner. He is very bold in defence of his young, and I have known instances of a very brave cock attacking a dog, a sparrow-hawk, and even touching a man as it flew past him. Cock Grouse will often fly straight at a man's head at this season, as if to attack him, but they generally swerve off at the last moment and resort to all sorts of devices to lure or scare him away.

The hen bird sits close on her eggs or young, but not so close as the female ptarmigan, which can be approached and even stroked at this time. Both the female and her chicks harmonise so closely with the surrounding herbage that it is most difficult to detect them. Once I actually trod on a female that was covering her chicks, and she left some feathers under my boot in her hurried departure.

Young Grouse are very difficult to rear. I succeeded at the third attempt in bringing up four out of a clutch of eight, under a bantam hen. The young fly quite well even when no bigger than sparrows. It is not difficult to get the young to eat ants' eggs, insects, eggs, meal, clover, and young heather shoots; but they, like young blackgame, have a way of dying suddenly, without any apparent cause. The difficulty is, I think, as my friend Mr. Hugh Wormald suggests, to get them the right insects and grass seeds. Mr. Wormald, who has been most successful in rearing young birds of different species, furnishes me with the following interesting notes of the plumage of some young Red Grouse he attempted to rear:-

" I st Day.-Down yellowish brown, marked with black and dark brown; the top of the head gives them the appearance of having brown caps on. Feet and legs thick and covered with yellowish grey down. Some of the brood much yellower than others. Beaks very short and small, black; the feet are 'furred' almost as far as the claws.

" 3 rd Day.-Primaries and secondaries just beginning to show.

" 5 th Day.-Primaries and primary coverts going well, dark brown with lighter yellow edges.

" 7 th Day.-Scapulars just showing, all the wing feathers growing fast.

"gth Day.-Primaries, secondaries, and both wing coverts well developed; tails coming in and scapulars growing fast.

" Ioth Day.-All dead."

When flushed off the nest the hen flies straight away, keeping low and not going very far. On settling in the heather she runs, hides, or sits watching the disturber, whilst the cock flies far away, as if he had no responsibilities. Immediately the young are hatched the hen will sometimes not take wing at all, but merely run a short distance, watching you 


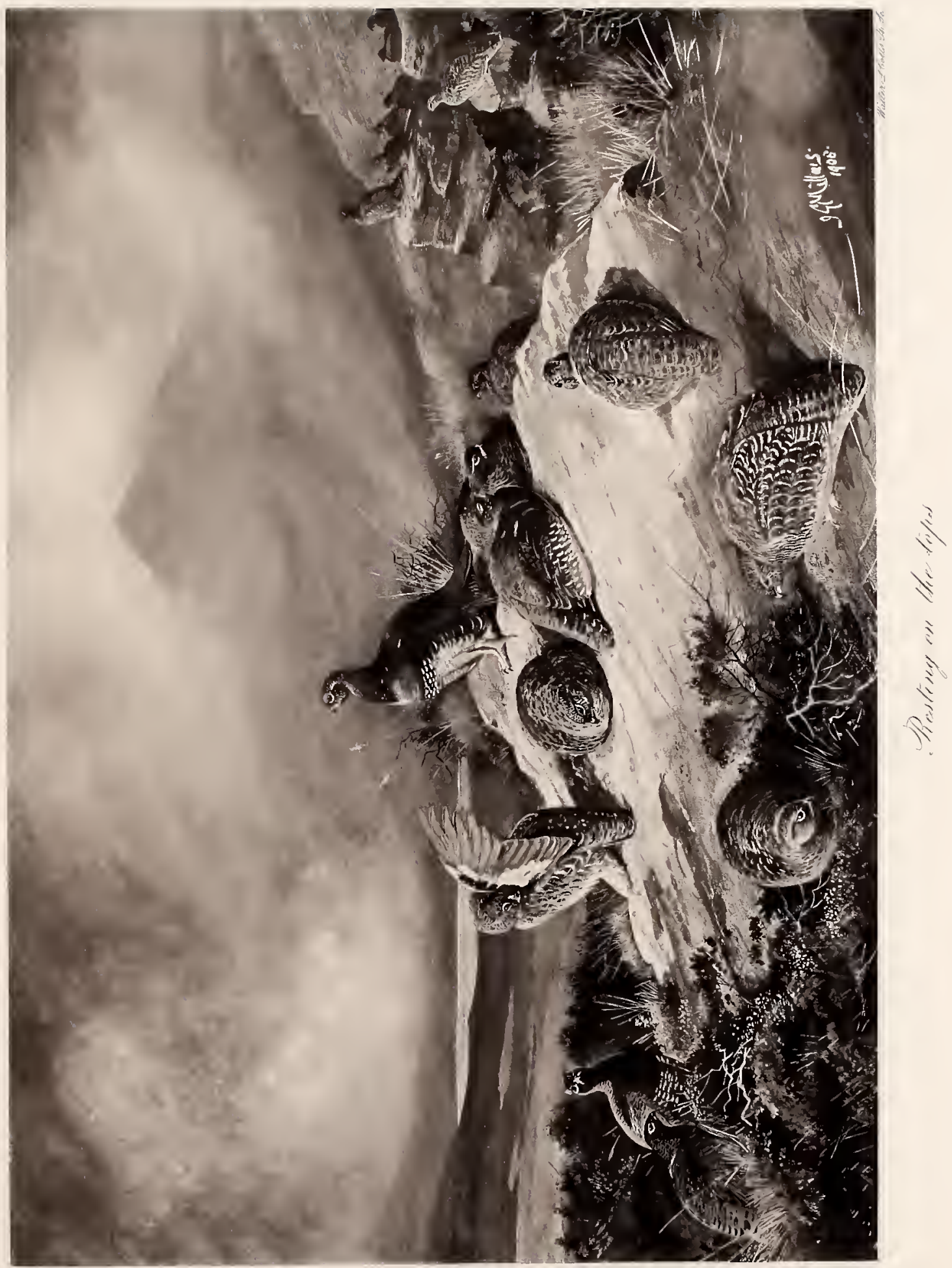



as if with reproach. The cock will sometimes do the same, or both parents will resort to demonstrations by flopping about and pretending to be wounded.

As the season advances young Grouse soon become strong on the wing, and accompany the parents on long flights. If the weather is stormy, it is not unusual to find considerable packs as early as the ist of August. Grouse shooting commences on August 12 th, and lasts until December Ioth. During this time immense bags of Grouse are shot in England, Scotland, and parts of Wales, the great majority now being killed by driving. Driving, which is certainly most beneficial, has almost killed "dogging" for game, because it renders the birds, especially on high or open moors, difficult to approach ; yet this sport may still be enjoyed on many northern moors, especially in Sutherland, Caithness, Skye, Orkney, and the Hebrides, where the birds sit well until the end of the season. In Ireland, too, Grouse will generally sit to dogs until December. As a matter of fact, Grouse are wilder in September than at any other season, and if the season is stormy they assemble in great packs, which are usually unapproachable.

During wet weather Grouse have a great dislike of getting wet on the under parts and tail. At such times they resort to exposed situations, and look very curious trotting about with their tails raised in the air. With fine frosty weather in October, Grouse become much tamer and sit about in pairs or in small parties. At this season a favourite sport in the border counties is "carting" to Grouse, which has been well described by Mr. Abel Chapman in his interesting book, Bird Life of the Borders (pp. 110-124).

The literature of Grouse shooting is now so voluminous that little need be said, beyond referring the reader to the many excellent books on the subject. Huge bags have been secured, both by parties and individuals anxious to secure records. No one perhaps will take exception to an individual gunner of exceptional skill killing a great number of birds on one particular occasion, if it is merely to see what can be done on a certain moor; but the general practice of parties shooting only once or twice in the whole season with a ridiculous number of guns and two loaders apiece, for the purpose of creating records, is much to be deprecated, because it savours of a certain vulgarity inimical to true sport. Some men like to see their names in the papers, and the big bag they and their party have made, but do they really enjoy it as much as the days of 70 to 100 brace, repeated several times in the season, in company with a few chosen friends. I think not. I have taken part in making bags of 200 and 300 brace of Grouse; some I have greatly enjoyed, and some not. It all depends on the way it is done. I shall always remember the best day's Grouse shooting I ever had. It was at Syre in Sutherlandshire, which my uncle, George Stibbard, rented for many years. The date was October Ist, and with four pointers I got $40 \frac{1}{2}$ brace of Grouse, nearly all old cocks. The birds were fairly wild, but scattered in twos and threes on a fine day, and shooting with a full choke and No. 4 shot, I had hardly an easy shot the whole day. A cock Grouse killed at this season is worth a dozen in August.

Grouse and blackgame are poached in a variety of ways. In Cumberland fine nets are hung above the walls, and the birds taken in flight. In Scotland many are snared and a few caught by hand on the stooks, whilst in Caithness I know of certain moors which have been nearly ruined by crofters and farmers shooting Grouse about the stacks and farmyard in winter with the .22 rifle and silent smokeless cartridges. In the North, 


\section{The Natural History of British Game Birds}

too, large numbers are taken at night with the silk net, when the birds are roosting. The method is simplicity itself. An old and steady pointer with a small lantern at its neck ranges as usual. When a "point" is obtained the poachers can, by watching the dog's eyes and noting the position of its head, see very clearly when the covey is close at hand. Two men then run the silk net over the heather in front, and if the first "cast" is not successful the second usually is. My uncle, Mr. George Gray, rented a small moor near Alyth, from which over Ioo brace of Grouse were thus taken in a few days. By a singular circumstance he received one morning a cheque for over $£ 40$, made payable to George Gray, by a game dealer in Leadenhall Market. Inquiry resulted in the arrest of the local poacher, whose name was also George Gray, and the punishment of the dishonest dealer. All kinds of vermin prey on Grouse, their eggs and young. Even an otter and a stoat have been known to catch and kill adult Grouse. In the mating season hoodie-crows make fearful havoc amongst the eggs, whilst peregrines, eagles, and buzzards kill large numbers of the half-grown poults. The hill-fox, too, is most destructive to hen Grouse when they are sitting.

Varieties of Red Grouse are not uncommon. The most frequent is that of birds showing white primaries and white patches on the chest. Another common variety is seen in birds marbled all over with white, with the hooped black marks (and sometimes the buff points) still visible. Yellow and buff varieties are also common, ${ }^{1}$ with the faint markings of the darker parts still showing. Of the foregoing I have seen so many examples that it is not necessary to remark upon their particulars of capture. White varieties are rare, and of perfect albinoes I have only seen one or two. I possess a steel-grey variety from Perthshire, and have one of the rare "blue-grey" varieties from the same county. Only about three examples of the last named are known. I have also a curious specimen, buff all over, with curious black longitudinal marking down the feathers, quite unlike any other Grouse I have seen. It also has a pure white chest. The bird was killed at Loch Kennard in Perthshire. It is doubtful if the jetblack phase of the Red Grouse must be considered an excessive example of the black form, or a complete melanotic variety. Under any circumstances it is very rare. I possess two examples from Nairnshire, and there is a fair specimen in the Perth Museuin from Perthshire.

On December 12, 1908, Mr. Austin Mackenzie described in the Field an abnormal Grouse, which he suggested might be a hybrid between a Grouse and a pheasant. As no such cross was known, I asked Mr. Mackenzie to send me the bird for inspection. This he kindly did. It proved to be the most interesting variety of a Red Grouse I have seen, and one of which I believed, at the time of receipt, there is no other counterpart in British collections. Most naturalists and sportsmen have seen examples of the chestnut variety of the common partridge, when the chestnut of the breast seems to suffuse in patches the entire plumage, except the parts of the head and under parts. These abnormal birds were known at first as a distinct species. The Grouse in question is a similar variety; the red-chestnut of the front of the neck covers the head, neck, and breast, back, scapulars, and tail coverts. The wing coverts are chestnut with black edges, and the flanks, belly, red with black edges. On the nape are a few black and

\footnotetext{
I I have recently seen no fewer than six examples of the buff variety in Longshaw Lodge, Derbyshire.
} 


\section{The Red Grouse}

blood-red feathers, legs normal and well feathered with white. The bird in question was an adult male in fine plumage, weighing $28 \mathrm{oz}$. It was killed at Carradale, Argyllshire, in October 1908, and is now in my collection. Since writing the above, I have seen a second specimen shot by Sir Peter Walker in Arran, in September 1907. There were several birds in the covey all of the same curious colour.

The Red Grouse has been known to hybridise with the black grouse (of which I give examples in the article on that species), ptarmigan (?), and bantam fowl. Of the last named I have already recorded the only known instances. Two were dirty white (taking after the parent male-a white bantam); in form they were midway in shape between the parents-very uninteresting-looking birds. They belonged to my friend, the late A. G. Moore, and were reared in Ireland. They are now in the Dublin Museum. The third example is an exceedingly beautiful bird, of which I gave a figure in Game Birds and Shooting Sketches (p. I46, chap. ii.). This remarkable bird was raised by an old priest, Father Ryan, of Tipperary, and sent to Mr. Williams, the Dublin taxidermist, from whom I bought it in 1892 . The bird is somewhat larger than a Grouse, with a broad, wedge-shaped tail, something like that of a female bantam. The whole plumage is very soft and glossy, and of the same colour as a cock Grouse, but with fine markings and a black throat and chest. The nape is pale yellow, and the bill strong and well hooked. The priest in question kept the hybrid for five years, and it was a desperate fighter, beating all the other bantam cocks. One evening it was found dead, having at last met its match.

I have on several occasions been asked to examine what were supposed to be undoubted hybrids between Red Grouse and partridge, but in every case I have found the birds to be the somewhat rare blood-red variety of the partridge, at one time known as Perdix montana. I do not think that a cross between the two species is possible, although many hill partridges live all the year round on Grouse ground. I have seen an amorous cock Grouse chase a female partridge, but then I have also seen a blackcock do the same when a brace of partridges unwittingly strayed on to the playing-ground.

Grouse make very delightful pets, and in Game Birds (pp. 127-133) I have given several instances of the pleasure they have afforded their owners. One bird soon acquired the habit of roosting in a beech-tree with its foster-parent-a bantam hen-and another would even accompany shooters to the hill, and was so insulted at being "pointed" by a $\operatorname{dog}$ that it attacked the quadruped.

In $1907 \mathrm{Mr}$. W. Steuart-Menzies introduced from Norway to Speyside a number of Willow Grouse (Lagopus albus), or as they are called in Norway, the Dal-ripar or Skor-riper. Mr. Menzies' letter in the Field (February I, 1908) explains his experiment:-

"It may interest some of your readers to know that I imported some Norwegian ryper, or willow grouse, in the spring of $190 \%$. These birds were turned out in the north of Scotland, and seem to be acclimatising themselves very well. When they arrived, in March, they were snowwhite, except for a black line at the point of the tail feathers. They were very tame, and fed eagerly at once on the blaeberry leaves and birch twigs. They ate little heather and no grain, never having seen the latter before, I suppose. After ten days I turned them out of the pen I had confined them in, when seventeen of them flew about a mile on to the open moor, whence they 


\section{The Natural History of British Game Birds}

must have distributed themselves over the country, as I heard of some shortly after twenty miles away. The rest stayed near where they were enlarged for some time, but gradually went off to other parts of the ground, leaving only five birds in the original spot. I only know of one pair which nested; these had six young ones, with little white on them compared to young ryper in Norway. Two or three mated with red grouse, but with no result so far as I know. This may have been due to too short a residence in their new home. I hope this summer to find several coveys of both pure ryper and cross between ryper and red grouse. I have heard of five or six casualties, but $I$ hope the bulk of the ryper are still safe in the district.

"This year I have persuaded one or two friends to turn some down, and it will be interesting to see what the result is. The ryper would be a great adjunct in many places where there are woods with blaeberries and birch, especially on the west coast. Disease has never been known amongst them, and if they cross with our grouse it might possibly do something to prevent this epidemic. I should not wish to introduce too many of these birds, so as to spoil the personality of our indigenous red grouse, but the ryper is undoubtedly of value as an extra game bird for the wooded parts of our hills. It is a beautiful sight to see a pure white covey flying over the heather, and the cocks hovering and crowing as they descend on a tree root or bare spot. They seem to adapt themselves to any place easily, and have been feeding on the stooks with the red grouse. I have now got some in captivity, in the hope that they may nest here next year.

W. Steuart-Menzies."

No doubt these birds will be a valuable addition to our game if they will continue in a habitat similar to that in which they are found in Norway, namely, the low birch region, above the pines. But will they do so? Personally, I doubt it. Being practically the same bird as the Red Grouse, I think that as time goes on they will interbreed freely with our species and become involved and lost in association with the insular race. Mr. Harvie-Brown, in a letter to Country Life (March I4, 1908), evidently does not look on the experiment, such as it is, with any great favour, and apprehends danger to our beloved blackgame, by the Willow Grouse depriving them of their food. This I do not for one moment believe. In any case, there are all too few blackgame to eat the birch buds and other food enjoyed by both species; whereas if you could get an excellent game bird, such as the Willow Grouse is, to frequent an area which would be avoided by Red Grouse, such as the fringe of the moor, and if it would remain pure and prove itself as numerous and free from disease as it is in such districts as Lapland, Vesteraalen, and Stavanger, sportsmen as well as naturalists would be fortunate.

Nearly all introductions of game birds are doomed to failure if conducted on a small scale, and I fear that unless Mr. Steuart-Menzies will repeat his experiment at frequent intervals, and also induce some of his neighbours to do the same, the result will not be successful. 


\title{
THE COMMON PTARMIGAN
}

\author{
Lagopus mutus, Montin \\ LOCAL Names :-Ptarmigan, Rock Partridge, White Partridge; Gealag bheirne, Ian Ban ant-Sneac, \\ Sneacag, Tarmachan, Tarmachan Beinne (Gaelic); Fjal-ripe (Norwegian).
}

\section{Winter Plumage.}

Adult Male.-Pure white, with tail black and often well margined with white. In winter the tail-coverts are carried so that the tail is almost invisible, and the bird appears quite white, except for the black bill and black patch extending from eye to upper mandible.

Adult Female.-Similar to male, the only difference being that the black patch in front of the eye is absent or rudimentary. The female is somewhat smaller than the male.

\section{Summer Plumage.}

Adult Male.-Throat and under parts white, wings white with primary shafts black, and the median and secondary wing coverts adjoining the scapular are black with white tips, with a few brown and black barred feathers intermixed. The flanks, breast, head, neck, and the whole of the upper parts are grey, with red-brown intermixed and transversed by black bars. In many specimens seen in May in full breeding plumage the whole end of the feathers of the breast and back are edged with crescent-shaped tips of white. These white tips wear off in early July. I have seen adult males retain two or three of the pure white winter feathers on the back and tail coverts as late as June.

Adult Female.-General colour of upper parts, head, back, breast, and flanks, rufousbuff, heavily barred with black, and the same concentric white tips to the feathers. The whole of the under parts except the lower belly are also interspersed with these rufous and black feathers; throat white, under tail-coverts rufous and black-barred. Its most variable character is the tail, which in some specimens is brown-black all over. Sometimes each feather is broadly edged with white, and sometimes it is half or wholly transversed with sandy rufous bars. No two specimens are alike in this respect. The feathers on the legs and toes of both sexes are almost grey, and not the pure white of winter.

\section{Autumin Plumage.}

Adult Male.-The male undergoes a very general moult throughout July and August, but it cannot be said correctly that the change is a complete unit in itself, because in late September the winter plumage of white comes and gradually mixes with it. This change I will refer to later. In August the nails of the claws are renewed. In autumn dress the whole of the dark parts of the summer plumage are replaced by grey feathers finely hooped and vermiculated with narrow black lines. The throat is now covered with black feathers with white ends, and the crown of the head and a circle of feathers 


\section{The Natural History of British Game Birds}

round the neck is often russet brown broadly crossed with black bars. In September these parts change to grey. In fact, both in the case of the male and the female, the whole plumage is undergoing a colour change as well as a moult throughout August, September, October, and November; the birds apparently having the power to assimilate their plumage to the local environment to a wonderful degree. In mild winters, when there is little snow, we see both males and females retain many of the grey autumn feathers on the back, scapulars, neck, head, and rump, whilst in seasons of much snow the birds will, in December, lose these and become quite white.

Adult Female.-The female acquires her autumn and winter dress more slowly than the male. In August it is common to see examples with the head unchanged and many of the old summer feathers still retained till the end of the month on the neck, head, and scapulars. When the new winter feathers come in at the end of October many of these are seen to be not white, but partly coloured grey and white. These new feathers are not again renewed as some naturalists would have us believe, but change the grey colour to pure white, either suddenly or gradually, according to weather conditions. The general colour and markings of the female in August and September are a lighter tint of grey than the male, and the black vermiculations finer.

Male.-Length, 14.5 in.; wing, 7.6 in.; tail, 4.6 in.; tarsus, I. 3 in.

Female.-Length, I4 in.; wing, 7.4 in.; tail, 4.1 in.; tarsus, 1.3 in.

The plumage of the Ptarmigan is difficult to understand, because it is seldom stationary for any length of time, except in summer. A brief summary of these changes will give the reader some idea of their monthly alterations.

January.-Males and females in the white plumage, sometimes with a few grey feathers on back, neck, flanks, or scapulars.

February.-At the end of this month, if the winter is mild, a few of the first summer plumage begin to show, always on the neck.

March-Summer plumage coming in gradually ; birds in full moult, except primaries, secondaries, and tail, the breast and tail covert feathers not being complete.

April.-Summer plumage complete with a few winter feathers still on the tailcoverts (a single feather is sometimes retained until July).

June.-Summer plumage.

July. - A gradual darkening of the whole plumage due to tip-covering. I have seen Scotch males as black on the chest as Icelandic or Norwegian examples; commencement of the autumn moult.

August.-A very general moult to autumn plumage.

September.-Continuous moult; the head and neck of males turn from brown to grey. Tail and wings now renewed; females may still retain a few summer plumage feathers.

October.-Continuous moult of winter plumage now mixing with grey autumn plumage; the autumn feathers changing colour in sympathy with incoming white plumage, and the new winter dress exhibiting many partially grey and white feathers (in sympathy with autumn dress), which will in turn change to pure white. Leg and feet feathers now complete.

November.-A few of the autumn feathers remain in head, neck, scapulars, flanks, 


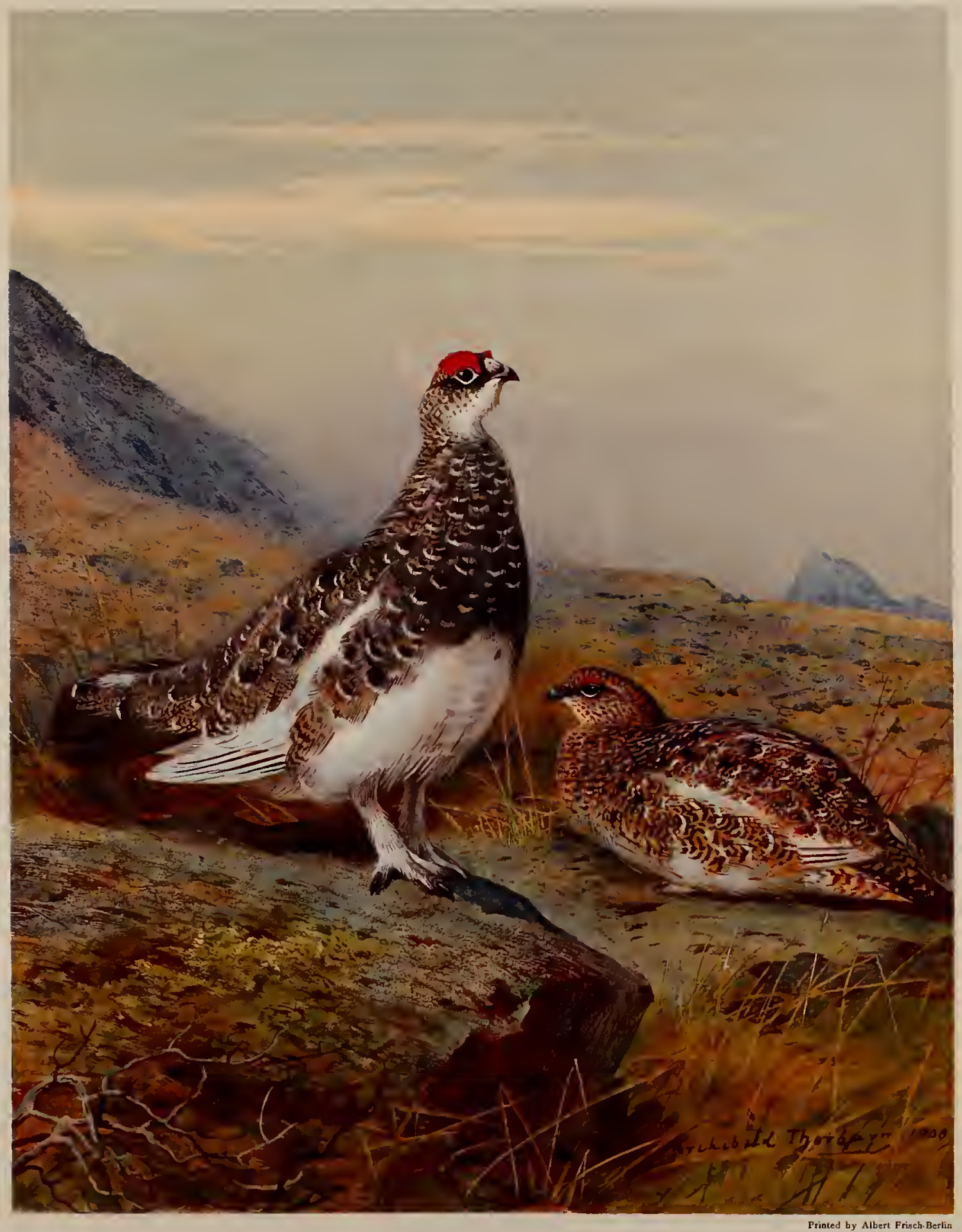

THE PTARMIGAN

Lagopus mutus

adult male and female, summer plumage 



\section{The Common Ptarmigan}

and rump, but they are paler than in the previous months. At the end of this month many are in complete white dress, which they retain till the end of February.

December.-A few, generally males, still retain some grey feathers. On the highest mountains in Scotland the proportion of pure white birds is greater than at lower levels or mountains facing the warmer winds of the west.

Young and Immatures.-Young Ptarmigan in down are very similar to young grouse, but are smaller and more golden in tint. They grow rapidly, and can fly well in eight days. In first plumage they resemble, according to sex, the parents in autumn plumage, except that the secondaries and flank feathers have a brown tint instead of grey, and are irregularly marbled with dusky black like young grouse. The feathers of the legs, feet, and belly are thin and downy, and the bill smaller. Early in October they can scarcely be distinguished from adult birds.

Distribution.-The Ptarmigan is found throughout the high mountains of Scandinavia, the Urals, and probably inhabits the mountains of Central Asia. The Ptarmigan of Northern Siberia is the closely allied L. rupestris, but to define the eastern limit of L. mutus is not at present possible. I could see very little difference between Ptarmigan I have collected in Iceland (where it has been described as a sub-species, Lagopus rupestris islandorum), Scotland, and Norway. Most of the males of Iceland and Norway are somewhat blacker in July, but that is all. Throughout Greenland and Northern America $R$. rupestris is abundant, and very similar sub-species also exists in Newfoundland, Labrador, Canada, Alaska, and contiguous islands. In Northern Europe the Ptarmigan is also found in the Alps, Pyrenees, Tyrol, Styria, and Carinthia, but is now extinct in Transylvania. Mr. Howard Saunders states that it is said to occur in the mountains of Leon and Asturias. It is also supposed to inhabit Japan. The Lagopus hemileucurus of Spitzbergen is closely allied to the willow grouse.

The home of the Ptarmigan in the British Islands is now confined to the mountains of Scotland, though it undoubtedly once inhabited the fells of Cumberland and Westmorland. The late Mr. A. G. More stated (Ibis, 1865) that there is a tradition that it once occurred in Wales, a view expressed by Macgillivray, Thompson, and Graves, but $\mathrm{Mr}$. Forrest has failed to find the origin of the fable. In Ireland it is unknown, and never existed there. Mr. Robert Service (Zool., 1887, pp. 8I-89) states that it existed in some of the high grounds of Dumfriesshire and Galloway until about 1822 , when the last was taken near Sanquhar; but a subsequent attempt at reintroduction by the Duke of Buccleuch met with no success. Howard Saunders states that it is found in decreasing numbers in Harris and Lewis, but $I$ think that it is now extinct there. In 1830 it was known to be in the Outer Hebrides (W. Macgillivray), and John Macgillivray speaks of Ptarmigan in $184 \mathrm{I}$ as occurring on Ben More and Hekla in South Uist. From inquiries I cannot hear that it exists there to-day, or that it was ever found in North Uist. Gray in $187 \mathrm{I}$ speaks of it as being wholly confined to the rocky peaks of Harris and Lewis. I feel sure it does not occur in South Harris, as I traversed the whole of the high ground in 1904, and the local deer-stalkers had never seen or heard of it in these hills. Harvie-Brown did not see a single bird in (North) Harris in 1879 . In $188 \mathrm{I}$ it was reported to 
him that it was "not uncommon" near Tarbert, but evidence points to the fact that it no longer exists in the Outer Hebrides. In Mull it still occurs in small numbers. In Islay and Jura it is now rare, and a covey is said to exist in Rum, where it was introduced by Mr. Bullough.' In Skye it is resident in the mountains above Broadford, and the Macleod informs me that the best Ptarmigan ground is above Sconser.

On the mountains of Scotland it is most abundant in West Ross-shire, especially on Coulin, Dundonald, Inverewe, Braemore, Loch Maree district, and I have seen large numbers in the Auchnashellach deer forest. South of this, too, it is very plentiful on Kintail, Applecross, and the high peaks of Braulen. In fact, all the mountains of over 2000 feet south of the Caledonian Canal are inhabited by Ptarmigan; and I have seen them in every high deer forest in which I have stalked in Argyll, Ross, Inverness, and Perthshire. They are particularly numerous on the western tops of Blackmount, and on the hills on the east side of Glencoe. In eastern Perthshire there are a fair number, on the highest hills about Pitlochry, Dunalastair, Dalnaspidal, Athole, and the whole range of the Grampians. This line they follow into Aberdeenshire, where they are still numerous, from Rothiemurchus and Mar to Ballater. In west Sutherland they are not nearly so numerous as they used to be, and seem to be dying out; but on the eastern mountains throughout the property of the Duke of Sutherland they still hold their own in small numbers. On the borders of Caithness it seems to be a disappearing species. Ben Lomond may be considered the southern limit in Scotland.

In Dunn's time (circ. 1870) Ptarmigan were said to still exist in Hoy, in the Orkneys; but Mr. Moodie-Heddle informed Harvie-Brown that the last were killed about 183 I by a Lieutenant Monro, then living in Stromness. ${ }^{2}$ In the Shetlands it has not existed at any period.

Habits.-The rocky boulders of the mountain sides above 1800 feet, and the stony tablelands on the tops, are the home of the Ptarmigan at all seasons, except in the severest weather, when the whole stock on the summits are driven to seek shelter on the lee side at a somewhat lower altitude. I witnessed a very interesting example of this from the door of my tent in Norway, in September 1907. Two days of ordinary snow made no impression on these hardy birds; but a blizzard from the north on the third day made all the Ptarmigan, to the number of, I should say, 800 or 100o, leave the tops and north faces, and come flying in coveys to a sheltered corner. They kept arriving for about two hours in a continuous stream. Next morning I passed through this sheltered hollow and moved hundreds of Ptarmigan, which only flew for a short distance, and as I did not wish to disturb the deer I did not fire at them. In the evening, however, I shot ten brace in about a quarter of an hour, and if I had had the wish and the cartridges I could easily have bagged forty brace. Next day all the Ptarmigan had returned to the high tops, and I did not again molest them, as I had a plentiful supply. Ptarmigan seem to like the snow, provided it is accompanied by a wind. No matter how cold the temperature or heavy the fall, if bare patches are swept clear they will stay up at the 3000 feet level all the winter. But a big snow-

1 A Fauna of Argyll and the Inner Hebrides, p. 153.

a A Fauna of the Orkney Islands, p. I93. 


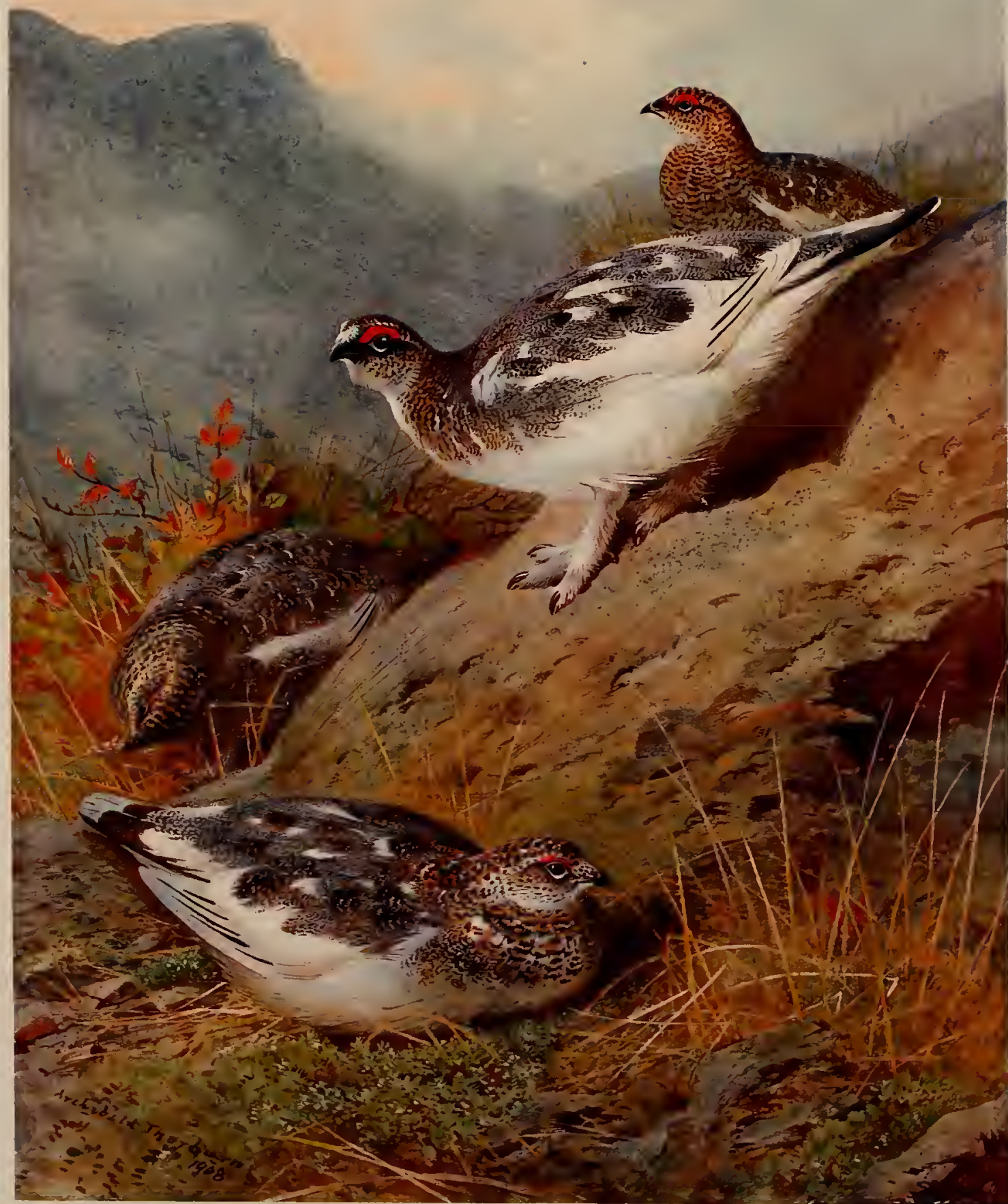

Printed by Albert Frisch-Berlin

THE PTARMIGAN

Lagopus mutus

adult male, fenale, and young, autumn plumage 



\section{The Common Ptarmigan}

storm, unaccompanied by wind, forces them to lower levels, or even causes them to migrate to snow-free ridges on other mountains.

No British game birds, not even grouse, are so influenced by atmospheric conditions as Ptarmigan. After a spell of fine sunny weather they are so tame that shooting them with dogs is not a very high-class sport; but even then they are not easy to find, owing to their crouching habits and the invisible grey of the plunage. If very closely approached, the old cock, who always remains with the covey in September, is nearly sure to call attention to his presence by suddenly springing up and running to a jutting point of rock and calling "Ptar," or "err-err." The rest of the covey then squat and stand round him, or run swiftly amongst the boulders. When slightly alarmed they nearly always jerk the head forward and quiver the tail, sometimes jerking the primaries, which hang low. At such times I have often shot them with my catapult. An Indian who accompanied me in Newfoundland was a deadly shot with a stone, a pocketful of which he always carried for the purpose of killing willow grouse. In boisterous weather their attitude towards man is that of extreme shyness. Even before wet weather Ptarmigan are often unapproachable for days, and they rise far out of shot and take long flights. They are also terribly frightened of the golden eagle, which makes them one of his principal sources of food, and on hills where they are subject to constant disturbances from these large birds they are always very wild. One covey rising sets all the others on the move. Whilst deer-stalking at Rothiemurchus a few years ago, I saw a golden eagle preceded by at least seventy Ptarmigan, probably the entire stock of the hill. They are very home-loving birds, and when food is plentiful will stay for years about the same mountain; but that they will migrate to other ranges there is no doubt. ${ }^{1}$ Their actual wing power-and they are furnished with larger wings in proportion to the body than any other British game bird-is very considerable. They will ascend and descend perpendicular slopes of several hundred feet without apparent effort, and no other game bird I know of can do so. Even the young, no bigger than thrushes, can do this. It is common to see a covey of Ptarmigan rise and suddenly shoot straight up or down a chasm and disappear from view, this being the subject of the beautiful drawing Mr. Thorburn has executed for these pages. Their wing power in making sudden turning movements is equally remarkable. I have seen old female Ptarmigan adopt a stratagem to attract their broods that I have not seen described in any book. If she is flushed singly and the young (even if full grown) do not follow at once, she flies straight away for about 200 yards, and then suddenly shoots up into the air for 20 or $30 \mathrm{feet}$, at the same time calling loudly "ack-ack-ack," or "ee-ack," to attract their attention. I have seen this done repeatedly. Under ordinary circumstances they rise and fly much like grouse, but swing up and down and in and out of hollows and corries with greater ease. When flushed from a top they sail out over space, and then take a sudden dive and a swing towards the rocks, conforming to the contour of the mountain. Except in bad weather and during the pairing season they are quiet in their movements, and sit or strut about in parties, the long-drawn cry of the cock often

1 A Ptarmigan has been killed on St. Kilda. In Labrador great migrations of L. rupestris takes place, extending over hundreds of miles. 
answering the male of another covey. They are fond of basking in the sun all day, and do not feed until the evening and early morning as grouse do, except in winter, when they burrow into the loose snow at all hours of the day. In Norway they often follow the reindeer in the winter, and dive into the holes made by these animals in scraping up the moss with their feet, thus obtaining a few ice-preserved berries. In winter they roost in the snow in a somewhat scattered formation, and not like partridges or grouse, which sleep close together. These roosting holes are easily seen by the dark pile of droppings in each. I think that in winter the Ptarmigan is spared as much from the inaccessible nature of its haunt as by the whiteness of its dress. Eagles do not seem to see them well at this season, and resort to the lower levels after grouse and blue hares. Most of the Ptarmigan stay all through the winter at the highest elevations over 2500 feet, except in very bad weather, and even then they ascend as soon as the wind drops and the sun comes out. If the snow drifts, they cannot scrape through it, and must resort to spots where the wind has swept the snow away wholly or in parts. I have seen Ptarmigan in October on the very summit of Brae Riach (4200 feet), one of the highest mountains in Scotland.

The food of the Ptarmigan consists of the fruit and shoots of Alpine plants. They are especially fond of blaeberry, both leaves and fruits, the black bear-berry and small red cranberry. If these are plentiful they will eat nothing else, but they do devour a certain number of small plant leaves, notably the green leaf called in Norway " reindeer grass," and of which I am not sufficiently capable as a botanist to give the correct names. I have often seen Ptarmigan down on the grouse ground at 800 feet, but do not think that they eat heather; still the evidence on this point is purely negative, and they may do so.

As the winter snow patches and drifts melt in March and April, the time of hardship for the Ptarmigan ends; for snow is a wonderful preservative, and spreads the feast in almost as good a state as when it covered it in October. As with grouse, the pairing season and the assumption of nuptial dress is deferred or advanced according to the weather. Good weather means plentiful food, and in consequence good condition and an early moult, and bad weather the reverse.

Ptarmigan seldom commence their matrimonial affairs until the end of April. They do not exactly hold a "lek" like polygamous species, but the actual courting and fighting first takes place within a small circumscribed area, as with partridges. The cocks fight and "carry on" just in the same way as grouse; the males, when seeking to attract the females, flying up and suddenly alighting whilst uttering their loud croaks. At this season the call is much prolonged, and may be heard before daylight. They fight most just at daybreak, and the calls and fluttering are incessant until ten o'clock, when they are comparatively quiet for the rest of the day until evening. I once spent three months on Ptarmigan ground in Iceland, and was camped amongst the birds the whole of the nuptial season. The fighting and show off was continuous until the end of May, when the birds were successfully mated. Then they are strictly monogamous, and most devoted husbands and wives. I have also spent the month of May in a deer forest, and have heard the Ptarmigan calling before daybreak, showing that they are even earlier risers than the blackcock. 


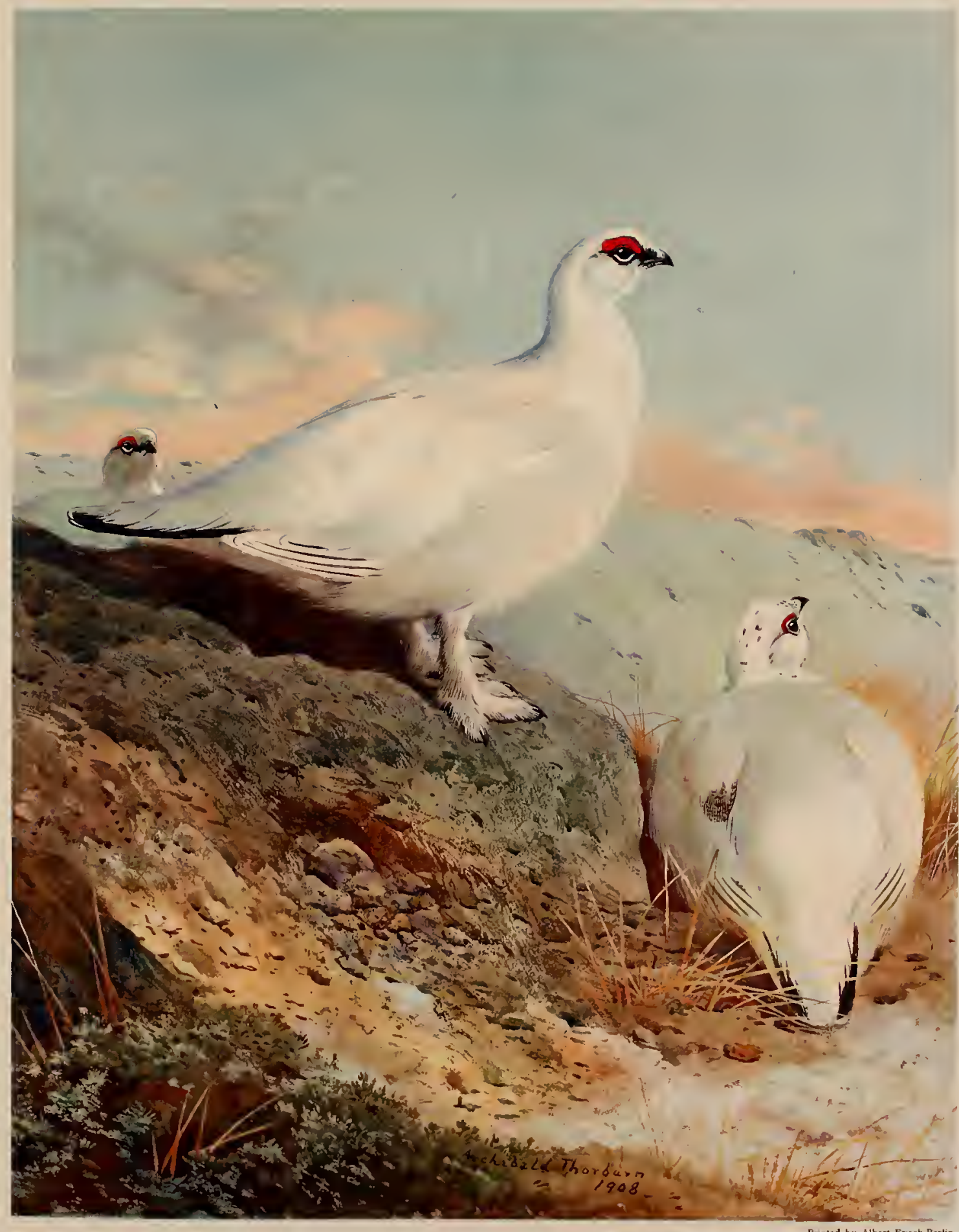

THE PTARMIGAN

Lagopus mutus

adult male and female, winter plumage 



\section{The Common Ptarmigan}

Up in their mountain solitudes in winter they have practically but one neighbour, the hill fox, who preys upon them at all seasons. The hill badger, so seldom seen at any time, is now fast asleep in his cairn, and the red-deer are away below in the valleys; but with the melting of the snows come the summer visitors in the shape of the ring-ousel, the golden plover, the common gull, the wheat-ear, the meadow pipit, the twite, and in a few places the beautiful dotterel and the snow-bunting. I had seen all these birds up on Ptarmigan ground between the "Sow" of Dalnaspidal and Braemar. In early spring the cock Ptarmigan often descend the mountain-side to the 800 feet level, and there sit and call, awaiting the rising of the sun. On the first streak of dawn they make short flights up hill, and take up positions overlooking a wide space. Here they sit and call and croak to each other at intervais. Again they mount higher, and keep on doing so until they have reached the regular spots where the females are to be found. About April zoth Ptarmigan are paired, and usually begin to lay about May 2oth, ${ }^{1}$ and sit about June 4 th. The nest is very similar to the grouse, but unlike that species is generally placed in a very open situation, such as rough blaeberry patches, but I have seen one under the shelter of a rock, and Mr. Seton Gordon says he found one in deep heather. Ninety per cent. of the nests are to be found on a southern slope. They are difficult to find, as the female sits very close. During the mating season many female Ptarmigan leave their nests, owing to late snowstorms, and I have found eggs laid on the edge of a fresh snowdrift, where a nest was doubtless buried. The eggs number from seven to twelve, but eight to nine is the usual clutch, and they are often impossible to distinguish from those of grouse. As a rule they are smaller, of a more reddish buff colour, with the spots and blotches close together. Size, I.7 in. by I.I in. I have searched for hours in vain to find a Ptarmigan's nest, and was not successful until an old keeper gave me the hint to search only a limit of two hundred yards square from the point the cock bird was first flushed. After this I was immediately successful, and found three nests in one morning." The nest is merely a scraped hollow. There is rarely any lining, but when the female begins to brood she generally lines it with her feathers. Since her summer plumage is often incomplete by June 4th, these feathers are often pure white, and make the nest at times conspicuous. On occasion she partly covers the eggs when she goes to feed, but more frequently the eggs are exposed, and a conspicuous object of attraction to any wandering gull or hoodie-crow. In certain parts of Aberdeenshire these marauders destroy half the nests in the hills.

The cock is a most devoted and watchful husband, never going very far from his wife, either when sitting or when she has chicks.. ${ }^{3}$ On being disturbed he flies in a circle and alights on the top of a large rock, from which he anxiously regards the intruder. The period of incubation is nine days longer than with grouse, perhaps owing to the greater cold. During the last few days of sitting the female is very tame, and will sometimes allow herself to be stroked or eggs to be taken from beneath her. When she is disturbed

1 Ptarmigan that have lost their first nests often lay again, sometimes very late in the season. I have seen downy cheepers in the middle of August, and have heard of their having been seen in September.

2 Mr. E. T. Booth relates how, after vainly searching for a Ptarmigan's nest, he found one between the legs of his pony as the lunch was being repacked. Another nest was discovered by his dog sitting down upon the sitting bird.

9 When first disturbed the cock grouse often flies right away from his family, and fails to put in an appearance afterwards; whereas I have never once disturbed a female Ptarmigan with young without the male appearing from somewhere and doing his best to create a diversion, even at the risk of his life. 
from the nest she half runs and half flutters over the ground, and is immediately joined by the cock, who seems to be thrown into some excitement at her leaving the nest, and runs in front of her as if to check her retreat, bowing his head up and down. Both parents keep up a melancholy croak.

The young are more active than young grouse, and fly very soon after being hatched. They eat quantities of young grass points and juicy blaeberry leaves broken up by the parent; but of their other foods I cannot speak with certainty. Insect life, on which we should imagine they would largely depend, is not very plentiful on the high grounds until July. Both old and young are very subject to attacks of vermin of all sorts. Foxes never cease hunting them, and hoodie-crows break the eggs as well as kill the nestlings. Common gulls, too, in Aberdeenshire, destroy a good many nests.

Mr. Seton Gordon says: ${ }^{1-}$

"At the present date of writing (June 25th), the majority of the ptarmigan are just beginning to brood on a second clutch of eggs, their first having been destroyed by the snowstorm three weeks ago; and apparently the second clutch consists of the same number of eggs as the first, that is to say, from six to eight. The hen lays an egg every day, and does not begin to sit until the whole clutch has been deposited, half covering the eggs when away during the day with lichen and moss. She hides them very imperfectly, however, and often they fall a prey to the hoodie or common gull. These birds had a grand feast at the beginning of June, after the snow melted and left exposed the deserted nests, and I found in a short time three nests with every egg sucked clean; what was rather unusual was the fact that the thieves had not even troubled to remove the eggs to a secluded spot. They usually do this if the rightful owner is still in possession, carrying the eggs in their bills to some stream or pool, as they seem to prefer the egg when it is helped down by a draught of spring water. As a rule, the ptarmigan nest above the heather-line, but on the Cairngorms on June 23 rd I found a nest among long heather in precisely the position a grouse would choose, about 2800 feet above sea-level. Apparently some of the birds have given up the idea of a second clutch, as I saw a pack of nine fly off together."

The cock bird is sometimes very daring in defence of his family. In Iceland the cocks almost invariably fly straight at your head as if to strike you, just swinging off at the last moment as you raise your hand. No doubt many pay the penalty of their courage at the mouths of stoats and foxes. Mr. Seton Gordon states ${ }^{2}$ that on disturbing a covey of young Ptarmigan the mother "flew right up to my feet and looked up at me appealingly." The young are not full grown until the end of August, and then form into coveys with the parents. Golden eagles have now become so plentiful in the deer forests that very few Ptarmigan would be left were it not for the broken nature of the rocks found at intervals along the hilltops. The Ptarmigan fly as fast as they can when flushed by birds of prey, and with a sudden header they disappear in a moment around and under the stones. I saw an eagle on Dundonald forest chase a covey of Ptarmigan into a mass of rocks. As soon as his quarry vanished the bird of Jove alighted on a rock and kept looking eagerly from left to right, as if expecting them to come out again. After waiting a few seconds he seemed to recognise that he was no ferret for routing amongst holes, and sailed majestically away.

The grouse-shooter and the deer-stalker look upon the chase of the Ptarmigan from 


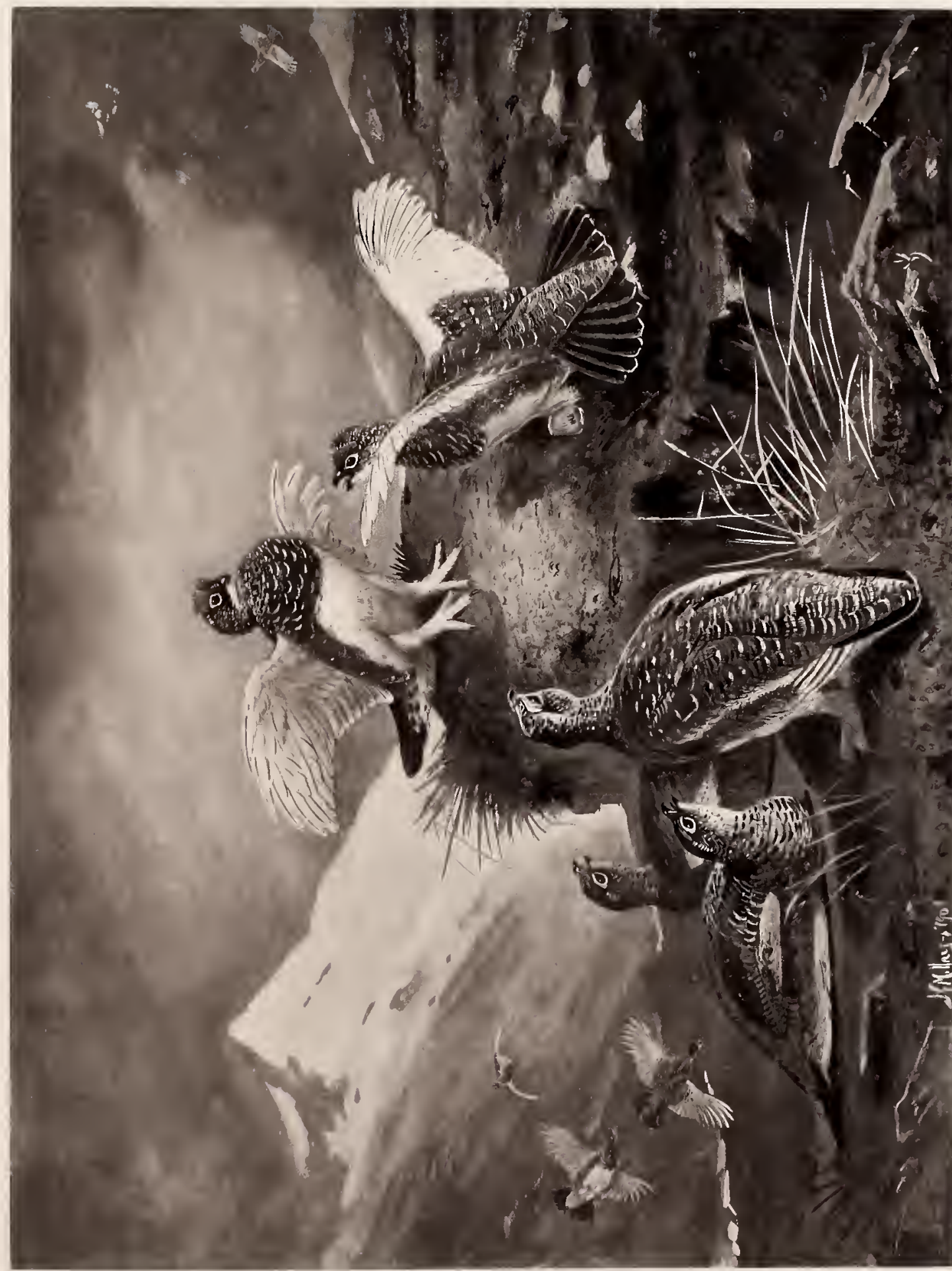





\section{The Common Ptarmigan}

different points of view. The former is now becoming a pampered individual, for whom sport is made too easy; whilst the latter does not look with favour on the reports of guns about the high tops, where if the wind is wrong the presence of one man may do considerable damage in moving deer off the ground. But for the young sportsman of the right sort who loves a good climb and to work for his game, Ptarmigan shooting, when practised on favourable days, offers very attractive sport. In a few places it is possible to drive Ptarmigan, and I have heard of as many as sixty brace being killed in one day, but the pleasantest way is to go out alone with one keeper and a steady old dog. An early start must be made, and if the day is fine, the gun held straight, and the gunner does not fear some stiff climbing, he will be rewarded with ten or fifteen brace. If you have an old gun it is best to take it, or the shooter may experience the horror of seeing his gillie tumbling down the rocks or over a snowslide with his best sixty-guinea weapon flying through space. This happened to me in Norway in 1907 , and the gun would have been reduced to fragments but that it fell on soft snow after a flight of about fifty feet. If it had gone three yards farther a sharp rock would have reduced it to atoms. August and early September are the best months to make a bag, but it is not always possible to shoot at this season owing to the exigencies of grouse and deer, but very pleasant days may be enjoyed on the tops in October after the stalking is over, although the weather cannot be depended on at this season. Even to the practised eye, Ptarmigan are most difficult to see unless they move or call. If suddenly come upon they usually rise and run a few yards, quivering the tail, and this at once attracts attention. At all seasons Ptarmigan may be found in pairs, so that the game is generally well scattered. There is a beautiful uncertainty about Ptarmigan shooting that is very attractive. The weather may be all that can be desired when the start is made, and even to half-way up the ascent. Then comes a sudden snow shower and the birds seem to vary their disposition according to the elements, and what looked like a good day may turn out to be a very poor one, with a procession of wild birds passing far out of shot, and taking flights of such length that it is impossible to find them again. I have often followed wild grouse all day, and by dint of pegging away have made a good bag in the evening, when the weather settled and the birds got "on feed." With Ptarmigan it is otherwise, and they seem to be "kittle" for hours before and after a storm. When Ptarmigan are only "half wild" they are difficult to shoot, as they turn and glide more rapidly than grouse. There seem to be few records of Ptarmigan shooting. The Hon. Geoffrey Hill killed in three days at Auchnashellach, I22, 82, and 60 Ptarmigan, and with two other guns, 92 in one day. Forty birds have often been shot in a day, but a larger bag is rare. In a single drive at Gaick twenty-seven have been killed, whilst sixty brace have been bagged there in one day.

In the case of Ptarmigan, Nature maintains an even balance, for though so little shot they do not increase to any extent, except for short periods. As soon as a large stock is created after one or two favourable seasons, vermin of all sorts find them out and harass them unceasingly at all times of the year.

In Game Birds (p. 175) I gave some illustration of a clever ruse sometimes adopted by poachers for trapping Ptarmigan. A bottle is thrust several times into soft snow, 


\section{2 \\ The Natural History of British Game Birds}

and grain placed in the cavity formed by the neck space. As the sides of the hole freeze the birds reach down, topple over, and become wedged in the prison, from which they are unable to withdraw themselves. A few grains scattered about lead up to the trap. Numbers of grouse and a few Ptarmigan are caught in this way, as well as with common snares.

On the Continent of Europe, and especially so in North America, Ptarmigan are migratory, performing journeys of hundreds of miles to escape the rigours of the northern winter. In Scotland they doubtless make short migrations just as grouse do, and these being performed at a very high elevation are not likely to be noticed by man. It is certain that Ptarmigan leave a high mountain and appear in considerable numbers on others where the stock was known to have been reduced to vanishing point, so that we must accept as a fact that they make small local migrations. Thus a writer, doubtless Mr. Gordon, in Country Life (Feb. 9, 1907), gives his observations on this question:-

"On several mountains that I know of where only a comparatively few pairs of ptarmigan are met with, and these very close to the summit, it would be interesting to know whether these pairs remain on the hill the whole year through, or whether they go to and from the other mountains in the vicinity. Morven ( $2862 \mathrm{ft}$.) in Aberdeenshire is far removed indeed from any other hills where the ptarmigan nest, so that the three or four dozen pairs which rear their broods on it must either remain there always or else fly a distance of a dozen miles at least in order to gain another hill where the species nest. Due westwards, Ben Avon (380o ft.) stands about fifteen miles off, and if the birds emigrate at all they would probably go to this mountain, as it is connected with Morven by a chain of lesser hills, on one of which, 'the Brown Cow,' ptarmigan are sometimes seen, although I do not know that they nest there. Then again, due south (about ten miles away) lies Mount Keen ( $3077 \mathrm{ft}$.), but between this hill and Morven is the valley of the Dee, so I should think it very improbable that the birds would fly between these two hills, as to do so they would have to pass over cultivated lands, which they would probably be unwilling to do. What seems to support the theory that they do emigrate is the fact that during some seasons there appear to be more nesting ptarmigan on Morven than in others, and it is rather interesting that on this hill, and on this one alone, so far as I am aware, one or two pairs are constantly seen on a certain part of the hill at an altitude of not more than $1800 \mathrm{ft}$. above sea-level, while on Loch-na-Gar, Ben Avon, and their other strongholds, they are rarely, if ever, seen below $3000 \mathrm{ft}$. and certainly not below $2000 \mathrm{ft}$. I have noticed that on this particular low-lying ridge the ground and plants are very well suited to the ptarmigan, and another reason which may possibly influence them is that perhaps there are too many pairs for the ground near the summit, and that some of the birds have to descend lower in order to find unoccupied quarters."

It might be supposed that since grouse and Ptarmigan frequently resort to the same ground, and do as it were overlap at the breeding season, ${ }^{1}$ that they would often pair, but this is not the case, and in spite of the fact that both species are monogamous. The first supposed hybrid was one shot on Ptarmigan ground at Kintradwell, Brora, Sutherland, by the late Captain Houston, on September I, 1878. The bird was shot from a covey of grouse. The late Professor Newton agreed with me that the bird which is now in the Cambridge Museum possessed all the points that such a hybrid would exhibit, for it is of small size, and the feathers are a perfect blend of the two species. This bird I figured in Game Birds and Shooting Sketches (p. 183, and ed.); yet on a further examination of the specimen, in conjunction with Professor Newton, I

1 I have known grouse nests at an elevation of over 3000 feet, which is well within the Ptarmigan area. 


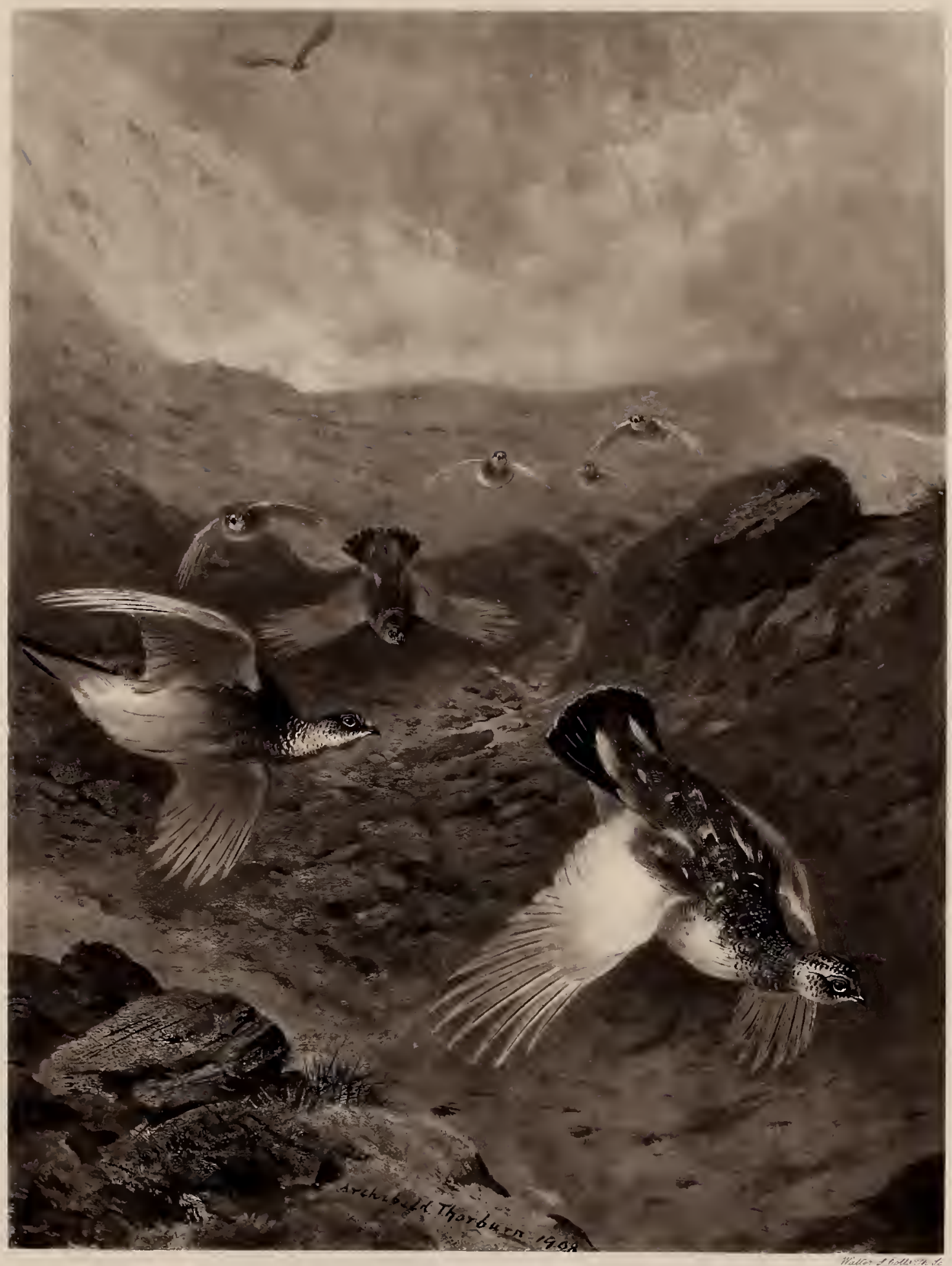

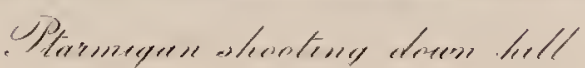





\section{The Common Ptarmigan}

am forced to admit that it is more than possible, and even probable, that it is very uncommonly marked small red grouse variety. Two very interesting birds which Mr. Grant thinks are undoubted hybrids between the two species were exhibited at the British Ornithologists' Club on December i8, 1907. In British Birds (Feb. 1, 1908) Mr. Grant gives an interesting account of these specimens, and figures of each. It must be noted that the male bird bears, as the Field remarked, a strong resemblance to a Norwegian willow grouse with dusky primary quills. I think that its claims are quite as doubtful as the Kintradwell bird. The two supposed hybrids are thus described by Mr. Grant :-

"Figure 1. This fine adult bird, evidently a male, was killed at Kinloch Rannoch, Perthshire, on the 9 th September 1907, by Mr. H. B. Debenham, of Thrifts Hall, Theydon Bois, Essex, and was recorded in the Field of 5 th October 1907 , p. 631 . Mr. Debenham, who was kind enough to lend me the bird for exhibition, has informed me that it was shot on high stony ground at an elevation of about 3000 feet above sea-level, where Ptarmigan were numerous, but Red Grouse seldom seen. Though the bird did not rise with Ptarmigan, there were plenty of these birds close to it. The weight was $I \frac{1}{2} \mathrm{lb}$, equal to that of an average old cock Red Grouse.

"It may be described as follows : Bill stout, as in the Red Grouse. General appearance and style of coloration like that of a large Ptarmigan in autumn plumage, but the head, neck, chest, back, upper tail-coverts, and some of the flank-feathers are much like those of a Red Grouse changing from the autumn to the winter plumage. It must, however, be specially noted that some of the new winter feathers moulting in on the chest, back, and upper tail-coverts are white, indicating a tendency to assume the winter plumage of the Ptarmigan. The breast and under parts are pure white, and the under tail-coverts black, widely tipped with white. The terminal half of the primary quills is mostly greyish-black, partially edged with white, and the remaining basal portion is white ; the secondary quills are white on the outer web and almost entirely greyishblack on the inner web; the wing-coverts are mostly white, but many are partially black towards the base, and some of the lesser ones are black freckled with rufous, as in the Red Grouse. The wing measures 8 inches.

"It has been suggested (cf. Field, October 19, 1907, p. 720) by Mr. W. Steuart-Menzies that this bird might be one of the Willow-Grouse or Ryper (Lagopus lagopus) which he imported from Norway and turned down in Banffshire last spring, but a glance at its dusky primary quills is sufficient to show that one of the parent birds must have been a Red Grouse.

"Figure 2, the second example, which is undoubtedly a bird of the year, and almost certainly a female, has also the stout bill of a Red Grouse, and resembles in general appearance the male described above.

"It differs, however, in having many of the greater wing-coverts partially, and the median wing-coverts mostly, mottled with black and rufous and tipped with white; while many of the grouse-like feathers of the chest, sides of the back, sides of the body and flanks, as well as the upper and under tail-coverts, are conspicuously tipped with white. The wing measures 7.8 inches.

"It was killed on Malundy, $3293 \mathrm{ft}$., Monar Forest, Ross-shire, in November I874, by Mr. W. J. O. Holmes, of Strumpshaw Hall, Norwich, and was in company with two Ptarmigan, which had been mounted along with it in the same case. One of these, a male, is in autumn plumage, but with some white winter feathers on the throat, breast, and upper tail-coverts; the other, a female, is in full winter dress, with only one or two autumn feathers on the scapulars. Mr. Holmes has informed me that out of eleven brace of Ptarmigan killed on the same day, all were in autumnwinter plumage with the exception of the almost perfectly white female mentioned above, which must have attained its winter plumage at an unusually early date."

Figure 2 seems to me to be a fine example of excessive leucotism, a phase of red grouse winter plumage not rare on the very high grounds of Ross and Sutherland. (See figure of male, Game Birds and Shooting Sketches, p. 56.) 


\section{Genus Phasianus}

\section{THE TRUE PHEASANTS}

THE long wedge-shaped tail is composed of eighteen feathers, the middle pair being much longer than the rest. The third, fourth, and fifth primaries are the longest. The male has the sides of the face above and below the eye covered with scarlet skin, on which are patches and small spots of feathers; except in the case of the $P$. colchicus mongolicus and $P$. c. principalis the ear tufts are much lengthened, and in all cases the legs are ornamented with powerful spurs. The various species, or sub-specific local races, whichever the naturalist may choose to regard them, are all natives of Asia, including the islands of Japan and Formosa.

One of our highest authorities on the game birds, Mr. Ogilvie Grant, expresses his views ${ }^{1}$ on the position of the True Pheasants by means of the following table :-

I. Crown of the head, green or greenish bronze.

A. General colour of the lower back, rump, and upper tail-coverts yellow or red-bronze, glossed with purple or green.

(a) With no white ring round the neck, or with only traces of one.

In this group Mr. Grant includes seven species and sub-species: The Common Pheasant (Phasianus colchicus), sub-species the Talisch Pheasant (Phasianus talischensis), the Persian Pheasant (Phasianus persicus), the Prince of Wales' Pheasant (Phasianus principalis), the Zerafshan Pheasant (Phasianus zerafshanicus), Shaw's Pheasant (Phasianus shawi), the Tarim Pheasant (Phasianus tarimensis), the Oxus Pheasant (Phasianus chrysomelas).

(b) With a broad white ring round the neck.

In this group Mr. Grant includes (species and sub-species): The Mongolian Ring-necked Pheasant (Phasianus mongolicus), sub-species Severtzov's Ring-necked Pheasant (Phasianus semitorguatus).

B. General colour of the lower back, rump, and upper tail-coverts greenish or bluish slate colour, with a rust-coloured patch on each side (except in $P$. versicolor).

(c) With a white ring round the neck.

Three species are included by Mr. Grant under this heading: The Chinese Ring-necked Pheasant (Phasianus torqualus), the Sa-Tschen Ring-necked Pheasant (Phasianus satscheunensis), the Formosan Ring-necked Pheasant (Phasianus formosanus).

(d) With no white ring round the neck or with only traces of one.

Five species are enumerated in this group: The Chinese Ringless Pheasant (Phasianus decollatus), Strauch's Pheasant (Phasianus strauchi), Vlangali's Pheasant (Phasianus vlangalii), Stone's Pheasant (Phasianus elegazs), the Japanese Pheasant (Phasianus versicolor).

II. Crown of the head reddish brown.

Soemmering's Copper Pheasant (Phasianus soemmering $z_{2}$ is the only species of this group according to Mr. Grant.

III. Crown of the head white.

Reeves's Pheasant (Phasianus reevesii).

\footnotetext{
' Game Birds, vol. ii. pp. 6-7.
} 


\section{The True Pheasants}

The above, then, is a summary of Mr. O. Grant's very lucid exposition of the True Pheasants, and one with which no doubt a large number of naturalists will agree. But, on the other hand, many students of natural history, in which I include myself, are quite unable to accept all the local forms of the Common Pheasant scattered over an immense area and differing only in trifling particulars from one another as species, but look upon them as sub-specific races of the first described type, Phasianis colchicus.

Some authors regard Soemmering's and Reeves's Pheasants (Group II. and III.) as belonging to a distinct genus, Syrmaticus, on account of the length of the tail, but Mr. Grant does not do so, whilst he places in a separate genus (Calophasis) Elliot's Pheasant and Mr. Hume's Pheasant, which are clearly so closely allied to the two foregoing species. This seems to me inconsistent; either they should all come under the True Pheasants and be regarded merely as separate species, or the genus Syrmaticus should hold good.

Since the above was written the Hon. Walter Rothschild, in describing a new species of True Phasiamıs, $P$. mikado, has given excellent reasons ${ }^{1}$ for arriving at very similar conclusions to those which I have formed. He considers that the True Pheasants should be retained in one genus, which should include the following species and subspecies :-

1. Phasianus colchicus, with numerous sub-species.

2. " reevesii.

3. " ellioti.

4. " llumice, with two sub-species.

5. $\quad$ soemmeringi, with three sub-species.

6. " mikado.

My friend, the late Mr. Henry Seebohm, who paid great attention to the birds of this group, writing in the 1 bis for 1887 , said :-

"The fact that all true pheasants interbreed freely with each other and produce fertile offspring, may be accepted as absolute proof that they are only sub-specifically distinct from each other. Like all other sub-species, they only exist upon sufferance. The local races appear to be distinct enough, but they only retain their distinctive character as long as they are isolated from each other. The moment they are brought into contact they begin to interbreed; crosses of every kind rapidly appear, and in a comparatively short time the swamping effects of interbreeding reduce the two or more local races which have been brought into contact to a single and uniform intermediate race. Such swamping effects of interbrceding have practically stamped out in the British Islands the two very different looking races of pheasants which were introduced into them-Phasianus colchicus from Asia Minor, and Phasianus torquatus from China. The pheasant of the British Islands is, with very rare exceptions, only a mongrel between these two races, but, it must be admitted, a very healthy and fertile one.

"The intermingling of the several races in the course of ages, and the isolation of the different breeds in the valleys and river systems of Asia, have given rise to numerous sub-species which are found spread over that vast continent. The spread of scientific investigation is continually disclosing new pheasants, which it pleases the discoverers to regard as distinct species, but which are obviously only mixed races. Mr. D. G. Elliot, writing in I 872 , enumerated about a dozen. Mr. Seebohm, in the $I b i$ s for 1887 , described six as sub-species of $P$. colchicus (three of which were not recognised by $\mathrm{Mr}$. Elliot). These are $P$. principalis from North Afghanistan; $P$. persicus,

1 Bull., B.O. Club, Nov. 29, ז907. 
which Mr. Elliot regards as the same as $P$. shawi; and $P$. chrysomelas, which he regards as identical with $P$. insignis. In the following volume (1888) Mr. Seebohm enumerates seven races, of which the Chinese $P$. torquatus may be regarded as the type; of these two, $P$. vlangali and $P$. sirauchi, are not described by Elliot. Of the others, the most strongly marked is the Japanese $P$. versicolor, which appears to me to be the most distinct and typical of all the true pheasants."

In Game Birds Mr. Ogilvie Grant enumerates eighteen species, and to these have been added three others by $\mathrm{Mr}$. Dresser and the Hon. Walter Rothschild-namely, Ijima's Pheasant, $P$. ijima (Dresser); Berezowsky's Pheasant, $P$. bevezowskyi; and Hagenbeck's Pheasant, $P$. hagenbecki (Rothschild).

It is quite possible that zoologists will never agree as to what actually constitutes a species and a sub-species. I have listened to and taken part in discussions with our best ornithologists on this point, and the result is ever the same. Like Omar Khayyám, we always come out by the same door as we go in. There are no uniform conclusions. Personally, I think that a bird or mammal is only entitled to specific rank when two distinct types overlap or are found in the same area, and do not interbreed. Where a local form of bird, owing to slightly different environment, varies in colour and size to some small degree, and does or would, if placed together with the parent race, breed freely and produce fertile crosses, these local forms are merely sub-specific races. Mr. Grant argues that numbers of the black-necked races of the True Pheasants have partial white rings on the neck, and that this variation is constant in what he calls isolated species. But the answer to this is that the geographical range of most of these so-called species is at present undetermined, and I maintain that he does not know for certain that these black-necked races are not in touch with white-necked ones at the present time, or have not been so recently. ${ }^{2}$ Travellers in the interior of China have found that between the Yangtze and Western Szechuen a day's shooting in one place will produce Pheasants of several of the so-called species, ranging from true torquatus type, with the broad white ring, to the dark ringless race. We know how freely all the local races will breed if allowed to run wild in our occurs islands, and the same thing applies to Asia in a broad sense, wherever contact by means of river systems.

\title{
THE COMMON PHEASANT
}

\author{
Phasianus colchicus, Linnæus
}

Local NAmes.-The old English Pheasant, Black-necked Pheasant, Ceiliog y Goed (Cock of the wood), lar Goed (Wood-hen), Ffesant (Welsh); Easag (Gaelic).

Adult Male.-Bill, pale greenish yellow; iris, yellow; bare papillar patch, scarlet; crown, bronze-green; head and neck, dark green, shading to purple on sides and front of neck. Mantle, chest, breast, and flanks, orange-red, edged with black bars and hoops suffused on the mantle with purplish green, and on the other parts with bright purple. Scapulars, rich orange-red, with a slight purple bloom, each feather in the

1 Bull, B.O. Club, Nov. 29, 1907.

${ }^{2}$ By recently I mean to infer some hundreds of years. 


\section{The Common Pheasant}

centre being marked with buff and black, and the yellowish quill down to middle forming a sharp line. Back, rump, and upper tail-coverts, maroon-red, suffused with purplelake. A few buff streaks on the back close to the scapulars. Wing coverts, sandy brown with a few red-maroon feathers below the end of the scapulars. Primaries, greyish brown, with sandy spots in the first half of their length. Belly, mixed dark brown and rufous. Tail, arched, long, and tapering of eighteen feathers, yellowish brown, with narrow bars of black, the outer feathers being much vermiculated with black; the sides of the tail feathers are a rich red-maroon glossed with purple lake. Legs and feet, grey, tinged with brown; spur, dark brown, and about a quarter of an inch to half an inch long. Length, 37.5 in. to 40 in.; wing, 10.1 in.; tail, $2 \mathrm{r} .2$ in.; tarsus, 2.8 in.; weight, $3 \frac{1}{2}$ to $4 \mathrm{lbs}$; exceptional birds of $4 \frac{1}{2} \mathrm{lbs}$. are often observed. The largest on record is of one noted in the Field (vol. xiv. p. 179). It was killed at Ganton, and is said to have been weighed by two persons as $1 \mathrm{oz}$. less than $6 \mathrm{lbs}$.

A dult Female.-General colour, sandy brown, barred, with black; feathers of the neck edged with black, suffused with metallic purple or green; mantle, dark chestnut, the broad black hoops shot with purple; scapulars, russet-brown, with black centre-edges sandy brown; centre quill, sandy yellow; tail, reddish brown, broadly barred with black on the middle feathers, and finely vermiculated with black on the outer ones. Chest and lower parts, sandy brown; feet and toes, yellowish brown. Length, 24.5 in.; wing, 8.6 in.; tail, I 1.5 in. , tarsus, 2.4 in. ; weight, $2 \frac{3}{4}$ to $3 \frac{1}{2}$ lbs.

Distribution.-The remains of Pheasants have been discovered in the Pliocene beds of Pikerni, and in Miocene deposits at Emingen and Allier, and on this the argument is based that the Pheasant was originally indigenous in Europe. It is almost impossible to define the true range of the Common Pheasant, ${ }^{1}$ since at various periods it has been introduced into the whole of Western Europe. Till recently it was not found in Spain or Portugal, but now it has been brought to both of these countries in large numbers. It is found in a wild state in Corsica, Turkey, the Balkans, Albania, Roumelia, Greece, Asia Minor, and on both sides of the Caucasus, and it extends northwards as far as the Volga. Eastwards it abounds along the southern shores of the Caspian to Astrabad, beyond which the desert intervenes and separates the true form from the various sub-species which occur in Afghanistan, Turkestan, Mongolia, \&c. Numbers are reared and breed in a wild state in Southern Sweden ${ }^{2}$ and Denmark, but north of this it does not exist or thrive in freedom. In the New World, both in America and Canada, the Common Pheasant and its various sub-species is becoming annually more popular. At the present time a few Canadian proprietors have met with success in rearing the birds between Toronto and Ottawa, whilst in the neighbourhood of Vancouver and Vancouver Island the species is well established in a wild state. ${ }^{3}$ A few rich Americans have Pheasant shooting in the Eastern States of America, and there is a growing industry in rearing Pheasants in the west, with Denver as its headquarters. The dry climate and abundance of insect

1 A tradition exists that the generic and specific name is derived from its introduction from the Colchian Phasis (now called the Rion), which flows in to the Black Sea near Poti.

2 In Baron Oscar Dickson's Island of Wisingso, in the Wetter Lakes 1548 Pheasants were killed in two days in I 893.

3 A resident near Duncans, Vancouver Island, told me he had shot 200 wild Pheasants in a season, and I saw many young birds there in the summer of 1908 . 


\section{The Natural History of British Game Birds}

life both in Western America and British Columbia is very favourable to the birds, but many perish in exceptional winters, not from the cold, but from thirst, due to the pools and streams being frozen hard.

Pheasants were introduced into Oregon in $188 \mathrm{I}$, and have since increased until they are in large numbers in the forests of the States. Owing to equable climate, the abundance of insect life, and the dry, sandy nature of the soil, the females are said to rear successfully 95 per cent. of their broods. The species is also fairly numerous in parts of New Zealand, especially in the neighbourhood of Auckland, and much interest is now being taken in acclimatising the new sub-species. There are also Pheasants in the island of St. Helena, introduced by the Portuguese as long ago as 1513. Owing to isolation and gradual deterioration they are now almost a new sub-species. A few Pheasants are amongst the recent introductions to Australia.

Mr. Henry Padwick kindly sends me the following references to Pheasants by Latin writers of the first century A.D. :-

"In the Satyricon of Petronius (chap. 93), Eumolpus the poet says that, 'Phcasants sought in Colchis and guinea-fowls in Africa, please the palate because they are difficult to obtain;' and in chap. 119, that the river Phasis has already been stripped of its birds to supply Roman luxury.

Petronius died 66 A.D.

"Seneca (ad Helviam, chap. 10) also complains of the extravagance of the Romans in sending beyond the Phasis for these birds.

Seneca died 65 A.D.

"Suetonius tells us that the brains of Pheasants and peacocks were ingredients in the famous dish or pie of Vitellius.

Vitellius died 69 A.D.

"Pliny, in his Natural History (Lib. 1o, chap. 48), mentions Pheasants as having two erect ears of feathers; and elsewhere, of their being infested with lice, which kill them, unless they dust themselves well.

Pliny died 79 A.D.

"Martial-who wrote in Domitian's time-in his very pretty description of Faustinus' well-managed farm (Lib. 3, Ep. 58) tells us that Faustinus, in addition to ordinary poultry, had domesticated French partridges (Picta Perdix), guinea-fowls, and Pheasants. In Lib. 13, Ep. 45, Martial, sending some poultry to a friend, writes that he is sorry he could not send guinea-fowls or Phcasants. In Epigram 72 of the same book the Pheasant is made to say', "I was first brought over here in an Argive ship-before that I knew no home but the Phasis.' This seems to allude to the mythical expedition of the Argonauts, and has no historical value.

Domitian died 96 A.D.

(The date of Martial's death is doubtful.)

"These are, I believe, all the references to Pheasants by writers of the first century A.D., and from them we may conclude that Pheasants were well known in Rome from the middle of the first century, and were always scarce and dear."

There seems to be no record of the first introduction of the Pheasant to these islands. Probably the sybaritie Romans, or even the earlier Phœenicians, brought the birds with other ornaments of a higher civilisation. In the excavations at Silchester, on the site of the old Roman-British town of Calleva (Car Segeint of the ancient British), Pheasant bones have been discovered, and this seems to be the earliest record we have of the presence of these birds in pre-Saxon times.

Pheasants are mentioned in the bills of fare of the Saxon kings, and it was known as a naturalised species before the Norman invasion. The authority for this statement is 


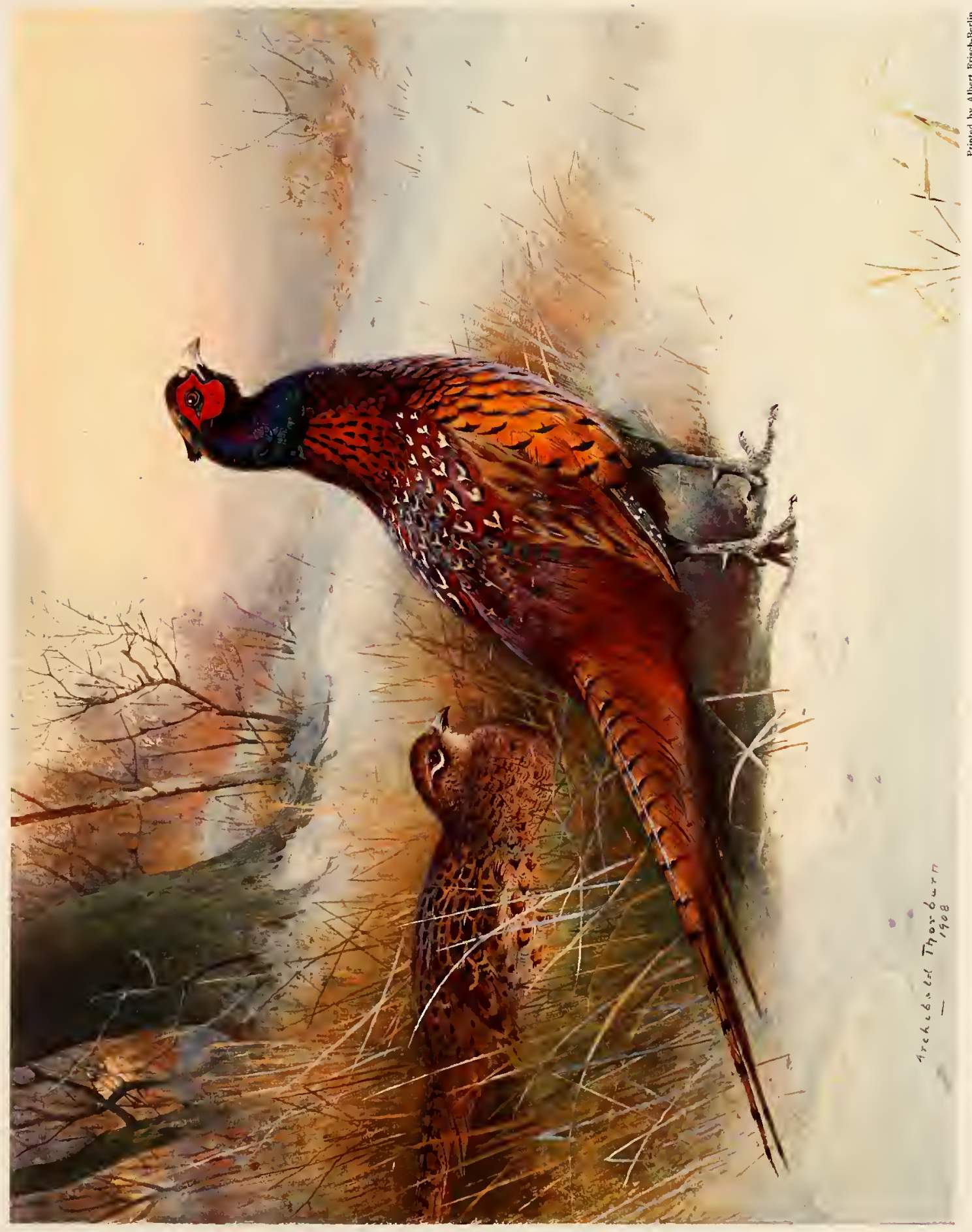

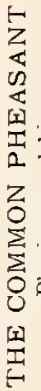



found in a tract, De inventione Sancta Crucis nostra in Monte Acuto et de ductione ejusdem apud Waltham." It is a bill of fare, drawn up by Harold, for the Canon's household of seven persons, A.D. 1059. The passage is as follows: "Erant autem tales pitantiæ uni cuique canonico: a festo Sancti Michælis usque ad caput jejunii [Ash Wednesday] aut xii merulæ, aut ii aganseæ [Magpies] aut ii perdices, aut unus phasianus, reliquis temporibus aut ancæ [Geese] aut gallinæ."

Dugdale, in his Monasticon Anglicanum, states that the Abbot of Amesbury (A.D. 1100) obtained licence to kill hares and Pheasants in the first years of the reign of Henry I. In 1245 the Custos (Master of Game) of the Bishopric of Chichester was ordered to send to the king for his use at Easter twenty-four Pheasants; whilst Daniell in his Rural Sports quotes Echard's History of England as the authority for the statement that in 1299 the price of a Pheasant was fourpence. Thomas à Becket (A.D. I170) was said to have dined on a Pheasant on the day of his martyrdom. In the reigns of Henry VIII. and Elizabeth, Pheasants are frequently referred to in writings of the period. Their price seems to have advanced to one shilling or thereabouts. ${ }^{2}$ From this date onwards the bird seems to have been well known throughout England.

The date of introduction into Ireland seems to be unknown. Thompson says that "in the year $15^{89}$ it was remarked to be common," whilst Fynes Morrison, who lived in Ireland from 1599 to 1603 , observes that there are "such plenty of Pheasants as I have known sixty served up at one feast," \&c. Gray, in the Birds of the West of Scotland, says: "The first mention of the Pheasant in old Scotch Acts is in one dated June 8,1594 , in which year a keen sportsman occupied the Scottish throne." James ordained that any person found "shooting deer, harts, pheasants, foulls, partricks," \&c., shall pay the fine of a hundred pounds.

At the present day it has been acclimatised throughout the United Kingdom, except in the most barren islands of the Outer Hebrides $^{3}$ and the Orcades. But little deviation from the true type occurred until the beginning of the nineteenth century, when the Chinese Ring-necked Pheasant ( $P$. c. torquatus) was introduced. Since this date the coalescence of the two forms has been so general that it is almost impossible to find $P$. colchicus in its original purity. Within the last few years, at the request of many shooting proprietors and tenants, considerable numbers of the true form have been introduced from Hungary and the Caucasus, and it is now possible to purchase them from some of the game dealers.

Habits.-Except in rare instances, where wounded or tamed birds have overcome their fears of man, the Pheasant consistently refuses all attempts at domestication, and proves, like the reindeer, that it is a wild creature and somewhat shy by nature. In this country and in Southern Europe and Asia Minor, its home is thick plantations with tangled underbrush and long grasses, especially so those that are well watered with streams and pools, and where the soil is of a gritty and sandy character. They

1 Edited from manuscripts in the British Museum by Professor Stubbs, and published in 1861 .

2 Interesting information concerning Pheasants at this period will be found in Harting's Ornithology of Shakespeare and Tegetmeier's Pheasants.

$s$ There are a few in North Harris, introduced by Sir James Mathieson, but they cannot be called residents, and will, I think, soon die out. 


\section{The Natural History of British Game Birds}

have a peculiar affection for reeds and long grasses of all kinds, and will leave wellfurnished covers and wander long distances in search of small spinneys and rough ground, even where big trees are absent, on purpose to attain such retreats. I think that the reason is partly the dislike of all forest birds to draughts, and partly because in such situations the greater warmth produces a greater abundance of insect life. In their home in China, Pheasants are most abundant in the dry reed beds fringing the margins of the great rivers, and the same applies to Turkestan, Afghanistan, Mongolia, and the Tian-Shan, in which our travellers after big game have always found them on the way to higher altitudes. In this country, where grass and reed beds are absent, I should describe a perfect Pheasant-cover as one on sandy soil having a slight southern slope, and protected on the ridge by a belt of Douglas firs; the valley should be intersected by a stream fringed with long grass and reeds, and the adjoining fields in high cultivation of buckwheat, oats, wheat, and turnips. The actual cover should consist of thickets, kept open in spaces, of brambles, snowberry, thorns, a few hollies and other short berry-growing bushes, and the whole of the ground well covered with various kinds of grass that run well to seed. Oaks and firs are the best trees for roosting purposes, but should not be allowed to grow too densely. Some years ago it was considered a good plan to plant masses of Rhododendron ponticum as cover and shelter, but this shrub has proved to be a failure and a danger in the Pheasantcover, both on account of its harbouring rats and rabbits, and for the fact that it "holds" Pheasants too closely when driving is in progress, and that the birds make no use of it in bad weather. It is also liable to spread too much, and thus ruin a wood. It is possible to have a few rabbits in the Pheasant-cover; but if a large number are kept, and are not well fed in winter, they soon render a wood uninhabitable to Pheasants by destroying the underwood and forcing the birds to become even greater wanderers than they are by nature. Rabbits in a wood are in time sure to be neglected, and gain the upper hand; when the undergrowth has departed the place becomes both draughty and no harbour for insect life, so necessary to the well-being of the Pheasant.

In bad weather Pheasants stay in the cover or close under the shelter of a wood, but on fine days they like to come into the open and scatter about on the open fields within such a distance that a retreat homewards is easily effected in case of alarm. Unlike many game birds, except for intervals of sunning and dusting, they often continue to feed and roam about all day long, although their regular periods of feeding are in the morning and the evening. In still frosty mornings, both in autumn and winter, they are apt to wander to great distances, and so to pass from cover to cover. This is especially the case where grass-edged streams and thick hedgerows form adjuncts to their original home, and unless prevented by frequent driving in, they will soon leave an estate that is not perfectly congenial. Like all birds and mammals of a wandering nature and with a taste for a varied diet, the Pheasant soon gets tired of eating the same things day after day. The keeper's corn may be excellent, but satiety soon prevails, and they like to explore on the chance of gaining variety. Naumann, the German naturalist, gives the following list of the Pheasant's diet on the Continent, which is so similar to that in our own islands that I quote it. He says :- 


\section{The Common Pheasant}

"Its food consists of grain, seeds, fruits, and berries, with green herbs, insects, and worms, varying with the time of year. Ants, and particularly their larvæ, are a favourite food, the latter forming the chief support of the young. It also eats many green weeds, the tender shoots of grass, cabbage, young clover, wild cress, pimpernel, young peas, \&c. \&c. Of berries : the wild mezereum (Daphne mezereum); wild strawberries (Fragaria); currants; elderberries from the species Sambucus racenosa, S. nigra, and S. cbulus; blackberries (Rubus cosius, R. idcus, and R. fruticosus) ; mistletoe (Viscun album); hawthorn (Cratogus torminalis). Plums, apples, and pears it eats readily; and cherries, mulberries, and grapes it also takes when it can get them. In the autumn ripe seeds are its chief food. It eats those of many of the sedges and grasses, and of several species of Polygonum, as $P$. dumetortm; black bindweed ( $P$. convolvulus); knot grass $(P$. aviculare) ; and also those of the cow-wheat (Mlelampyram); and acorns, beech-mast, \&c., form a large portion of its food in the latter months of the year. Amongst forest plants, it likes the seeds of the hemp-nettle (Galeopsis), and it also feeds on almost all the seeds the farmer sows."

To this long catalogue we can add its fondness for pig-nuts, buttercup tubers, the common polypody, peas, beans, acorns and beech-nuts, silverweed, ranunculus, and a host of grass seeds it is unnecessary to enumerate. I have heard of young Pheasants being successfully reared on horse-flesh, and they will always search horse-dung for the undigested grains of oats. They like earth-worms, and Mr. Tegetmeier records "that a Pheasant was killed in 1888 that had three young vipers in its crop." There are also two instances of their swallowing slow-iworms. Mr. G. F. Passmore records in the Field, June 2, I900, a case of a penned hen Pheasant's death due to its trying to swallow a large viper. There seems to be but little of an eatable size that a Pheasant will not attempt to swallow, for the same author records two instances of cock Pheasants being "killed by swallowing" alive a field-vole. Their fondness for snails, ants and their eggs, and slugs, is also well known.

Mr. H. Wormald writes :-

"In the early spring pheasants are exceedingly fond of the roots of the wild arum, or 'Lord and Lady.' I have known pheasants to die from the effects of eating hairy caterpillars of the woolly-bear type.

"A well-known Scotch forester, Mr. William Forbes of Blairgowrie, assured me that he had himself witnessed the following incident: He had been planting acorns covered with redlead, to protect them against the ravages of field-mice, when a cock pheasant came along, scratched up the acorns, took them in his bill, and deliberately wiped the red-lead off them on the grass, and then swallowed them."1

Pheasants do a considerable amount of damage in the spring to crops, and if you are the possessor of a rock-garden you do not love the old cock at any season, for he makes a point of scratching up and destroying your choicest treasures. They are also very mischievous in pulling off the flowers of daffodils. On the other hand, Pheasants are of the greatest assistance to the farmer by destroying vast quantities of injurious insects. Over twelve hundred wire-worms have been taken from the crop of a single Pheasant. Mr. Frederick Bond states in the Zoologist that he took from the crop of a Pheasant four hundred grubs of the crane-fly, one of the most destructive insects to pastures. Like the sparrow, the Pheasant has friends as well as enemies, but on the whole the verdict in its favour is overwhelming.

1 A Pheasant or a domestic fowl will always wipe away any objectionable matter from its food, and the fact that the bird in question did so does not prove the fact that it knew the poisonous nature of the red-lead.-J.G. M. 


\section{The Natural History of British Game Birds}

Mr. R. Carr Ellison states that Pheasants are particularly fond of the spangles of the oak, so common in autumn on the under-side of the leaves. Just before the fall of the leaf these spangles, which contain the dormant eggs of the gadfly (Neuroterus lenticularis), become detached, and on falling to the ground become an excellent winter store of insect food for Pheasants. Mr. Tegetmeier gives a very lucid account of how the digestive organs of the Pheasant assimilate the varied diet :-

"The structure," he says (p. 8), " of the digestive organs of the pheasant is perfectly adapted to the assimilation of the food on which it feeds. The sharp edge of the upper mandible of the bill is admirably fitted for cutting off portions of the vegetables on which it partly subsists, and the whole organ is equally well adapted for securing the various articles of its extensive dietary. The food, when swallowed, passes into a very capacious membranous crop, situated under the skin at the fore part of the breast. From this organ portions gradually pass into the true digestive stomach, or preventriculus; this is a short tube, an inch and a half long, connecting the crop with the gizzard. Small as this organ may be, it is one of extreme importance, as the numerous small glands of which it mainly consists secrete the acid digestive or gastric fluid necessary to the digestion of the food; and in cases in which pheasants or fowls are fed on too great an abundance of animal food, or any highly-stimulating diet, this organ becomes inflamed, and death is frequently the result. From the preventriculus the food passes into the gizzard, which is lined with a dense thick skin ; in its cavity the food is ground down to a pulp, the process being assisted by the presence of the numerous small stones and angular pieces of gravel, \&c., swallowed by the bird. The food, thus ground to a pulp, passes on into the intestines, which are no less than six feet in length; in the upper part of this long canal it is mingled with the bile formed in the liver, the pancreatic fluid, \&c., and, as it passes from one extremity to the other, the nourishment for the support of the animal is extracted; this being greatly aided by the operation of the two cæeca, or blind intestines, which are very large in all the birds of this group."

The late Mr. Charles Waterton published the following details of his method of preserving the Pheasants at Walton Hall:-

"This bird has a capacious stomach, and requires much nutriment, while its timidity soon causes it to abandon those places which are disturbed. It is fond of acorns, beechmast, the berries of the hawthorn, the seeds of the vild rose, and the tubers of the Jerusalem artichoke. As long as these, and the corn dropped in the harvest, can be procured, the pheasant will do very well. In the spring it finds abundance of nourishment in the sprouting leaves of young clover; but from the commencement of the new year till the vernal period, their wild food affords a very scanty supply, and the bird will be exposed to all the evils of the Vagrant Act, unless you can contrive to keep it at home by an artificial supply of food. Boiled potatoes (which the pheasant prefers much to those in the raw state) and beans are, perhaps, the two most nourishing things that can be offered in the depth of winter. Beans in the end are cheaper than all the smaller kinds of grain, because the little birds, which usually swarm at the place where pheasants are fed, cannot swallow them; and, if you conceal the beans under yew or holly bushes, or under the lower branches of the spruce fir tree, they will be out of the way of the rooks and ringdoves. About two roods of the thousand-headed cabbage are a most valuable acquisition to the pheasant preserve. You sow a few ounces of seed in April, and transplant the young plants 2 feet asunder, in the month of June. By the time that the harvest is all in, these cabbages will afford a most excellent aliment to the pheasant, and are particularly serviceable when the ground is deeply covered with snow. I often think that pheasants are unintentionally destroyed by farmers during the autumnal seed-time. They have a custom of steeping the wheat in arsenic water. This must be injurious to birds which pick up the corn remaining on the surface of the 


\section{The Common Pheasant}

mould. I sometimes find pheasants, at this period, dead in the plantations, and now and then take them up weak and languid, and quite unable to fly. I will mention here a little robbery by the pheasants, which has entirely deprived me of a gratification I used formerly to experience in an evening's saunter down the vale. They have completely exterminated the grasshoppers. For the last fourteen years I have not once heard the voice of this merry summer charmer in the party."

We may watch common birds and animals for 300 days in the year and never once see them do anything that is not well known to us, and yet on the $301 \mathrm{st}$ day an incident may occur which may be new. I had proof of this on the morning of April 18, I908, when I was walking in the forest of St. Leonard's with my wife. We noticed a fine cock Pheasant under a large holly tree about 70 yards from the path. Being in a place where people are constantly passing, the bird took no notice of us, but stood for a long time gazing upwards towards the outer branches of the holly. It being an unusual time of day for a Pheasant to go to roost, we halted and watched the bird, which presently opened its wings and fluttered up to a branch about 12 feet from the ground. Here its wings ceased to beat, and I saw it distinctly seize a berry and drop to the ground with closed wings. The Pheasant repeated the act five times as we watched it, and each time it picked off and swallowed a berry. I have not seen or heard of any gallinaceous bird doing such a thing before, and its actions were more like those of a warbler or a fly-catcher than of a Pheasant.

Another discovery in the natural history of the Pheasant was quite new to me, but it is known, I find, to a few who keep these birds in pens. It is that the cock Pheasant, when he has paired or gathered his wives, makes use of a gentle note or chuckle. This is constantly repeated as the male walks about with the female, but the observer must be within two or three yards of the birds or he cannot hear it. I was waiting for young rabbits one evening in May 1906, when I observed a cock Pheasant with two hens coming out of St. Leonard's Forest towards me. Pheasants are amongst the keenest-eyed of birds, and the smallest movement even in a tree will attract their attention. But I hid myself close to the trunk about io feet from the ground, and the Pheasant came to the foot of my tree and pecked about there for some time. I heard a curious crooning or chuckling note coming, as I thought, from one of the hens, but presently these passed away to some distance, and I ascertained that the noise was emitted by the cock. Since then I have had several opportunities of hearing the cock Pheasant use his amorous notes. Mr. Thorburn has a male which always keeps chuckling as it walks about the aviary with its hens in spring.

My excellent correspondent, Mr. Hugh Wormald, a close observer of birds, sends me the following interesting note:-

" $P$. colchicus, torquatus, versicolor, and mongolicus, all chuckle in the spring. At this season cock pheasants call their hens to feed when they find a special tit-bit, in the same way that domestic fowls do; the feathers are fluffed out and the head lowered over the object which they keep pecking at, at the same time making a crooning chuckle. I think this is a common practice among gallinaceous birds. Most of the quails do it, and when one sees male Harlequin or Chinese painted quails calling their hens to feed, it is a pretty sure sign that they intend to nest." 


\section{The Natural History of British Game Birds}

The hen Pheasant seems to have three distinct calls. The first may be described as a peevish whistle, which she uses on being frightened or flushed. The second is only emitted when handled and under extreme fear, like the words "ee-ac, ee-ac." The third note is heard when two hens are fighting, as they often do in spring. They make a purring sound when angry or actually in fight. When about to engage in battle, two hens lower their tails, spread them, and walk round and round each other, uttering this strange note.

The Pheasant is a bird that passes most of its existence on the ground, and seldom flies except to cross ravines or in going to roost. In the early morning they work out from the wood, and if undisturbed spend the greater part of the day in the open, on the sunny side of the cover; when food is scarce they get farther and farther away as the day advances, and if then disturbed invariably rise and fly homewards, unless very close to the wood.

The flight is strong, but not of long duration, and even with the assistance of the wind seldom exceeds half a mile. The elevation is entirely due to the obstacles it has to surmount on its way to the point of alighting. Thus a bird that is flushed on flat lands from woods will not rise higher than is necessary to clear the trees; whilst, on the other hand, a skilful keeper may cause Pheasants to rise to a height of 30 yards off a flat field, provided a wood behind the guns contains higher timber which it is necessary for the birds to "top" on entering. Pheasants seldom fly at a greater elevation than 100 feet, unless when crossing depressions. The pace varies from 20 to 30 miles an hour. As the bird rises the legs are bent and lifted, and when the necessary elevation is attained they are held straight under the tail. The head and neck are held straight out and the tail slightly spread. On reaching the end of a cover they strike the intervening small boughs and twigs in the act of descent, which is practically a skilful "fall" to the earth, and then run for some distance before beginning to look about and take their bearings. On sunny days Pheasants are often deceived on flying towards large houses by the reflection of the landscape in plate-glass windows. I have twice seen Pheasants crash through windows: once in Scotland, where a cock came with such force as to kill itself on the opposing wall; and once at Warnham Court, in Sussex, where the bird, a hen, though at first stunned, seemed little the worse of the accident. There are so many instances of similar accidents it is unnecessary to record them. I have more than once seen two Pheasants flying from opposite directions collide but without hurting each other. Mr. Purey J. Howes, however, records an instance (Field, November 10, 1908) of two Pheasants striking in mid-air, and both being picked up dead.

The small size of the wings are not adapted for prolonged flight; but that Pheasants are capable of flying for considerable distances is clearly shown by that excellent field naturalist, the late Mr. John Cordeaux, who states:-

\footnotetext{
"When shooting in the marshes on the Lincolnshire side of the Humber, near Grimsby, a man who works on the sea embankment came to say that two pheasants had just flown over from the Yorkshire side, alighting within a few feet of where he was working among the rough grass on the bank. On going to the spot indicated, I at once found and shot them; they were both hens, and in very good condition. The Humber at this place
} 


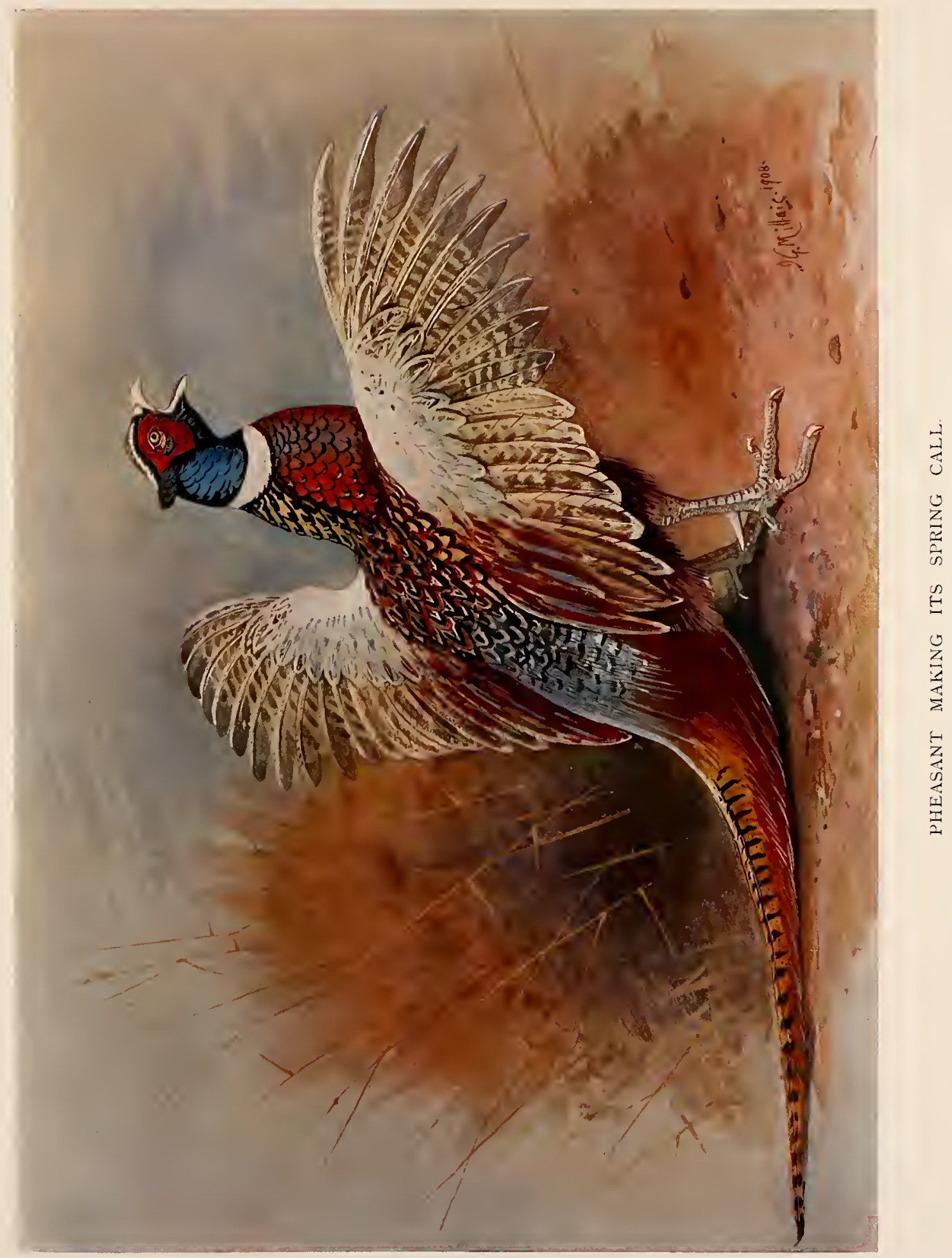





\section{The Common Pheasant}

from shore to shore is nearly four miles across. There was a strong northerly breeze blowing at the time, so that they would cross before the wind, or with the wind a little aslant. I have occasionally found pheasants in the marshes, and near the embankment, which I was sure must have come across, but had no direct evidence of the fact."

On the other hand, I have seen many instances of Pheasants losing heart after a considerable flight and falling to the ground or in the water. I was shooting the covers at Foyers, by Loch Ness, in December 1890 , when three Pheasants took wing from the south side and attempted to cross the lake at this point, about $\mathrm{I}_{2}$ miles wide. They rose at a considerable height, and after flying for about three-quarters of a mile all three alighted on the water, when they at once turned round and were captured by a boat whilst swimming homewards. I have also seen Pheasants fall or alight in the river Tay, and swim ashore. It seems to be well known that on occasions adult Pheasants will voluntarily swim across small pools and brooks in preference to flying over them, and various correspondents in the Field have recorded instances both of adults and young birds following their mothers across water. We have all witnessed the facility with which "winged" Pheasants will swim ashore to escape from a dog; and I have often seen hens dive for a few inches to escape being captured.

The usual cry of the male is a sharp "kok-cock," repeated three times. The young male begins to call in September, but the note is weak and unfinished until the end of October. At this season, too, both old and young cocks often make use of the cry with the subsequent quick wing shiver, which is always used as the season advances. I have two or three times seen cocks, both wild and in confinement, call and clap the wings at the same time, but the circumstance is rare. On spring days or fine frosty mornings in winter, one cock Pheasant will call and set all the rest of the males in the wood crowing. In fact, any unusual noise will cause Pheasants to answer, such as guns, explosions, bells, bands, or thunder. I live 4I miles from Portsmouth, yet every big gun that is fired there in spring is answered with the greatest regularity by every cock Pheasant in the forest of St. Leonard's.

Just before going to roost in spring and winter ( $\mathrm{I}$ particularise these seasons because young birds generally roost on the ground until October, and adults sometimes in summer) the male makes several metallic cries, whilst looking upwards and jerking his head towards the perch he has selected. As he flies up the usual cry is emitted, and if you are desirous of knowing how many cocks there are in a wood you can ascertain by listening. One winter I was staying for a ball and a shoot with a dear friend of mine, who has now passed on, when on asking a servant where the master was, was told that I would find him in such and such a wood close to the gate. Here I discovered him with a pencil and a note-book. I could not make out what on earth he was doing, when at last he rose and said enigmatically: "Eighty-one. I'm just counting how many cock Pheasants I'm going to show you bleary-eyed dancers to-morrow"; and he was quite right, for about that number came from the wood next day.

Mr. Ogilvie Grant is of opinion that the Common Pheasant is not by nature polygamous, and that in its true home it is monogamous, and that it takes part in protecting the female in the incubating period and subsequently in raising the young, 
and that such polygamous habits as it displays in our islands are due to force of circumstance, since there is a plurality of females at the end of the shooting season. This may be more or less true, but it is nevertheless a fact that in parts of Scotland, Ireland, and Wales, where no Pheasants are artificially reared, and where both hens and cocks are shot until the middle of the season, most of the cock Pheasants are polygamous. I should think, too, that if we knew a little more about $P$. colchicus in its purely wild state, we would find that it is polygamous there as it is here, especially so after a great "hen" year, when this sex predominates. At any rate, the evidence of the polygamous or monogamous nature is at present somewhat negative, but that cock Pheasants are often monogamous as well as polygamous in these islands there is no doubt, as well as the fact that on occasion they are attentive in watching orer the sitting hen, and even taking part in the duties of incubation. ${ }^{1}$

There are now so many instances of cock Pheasants taking their turn on the eggs when the hen is absent or feeding that I need not particularise them. Dogs and men have been attacked by cock Pheasants at such times, and Mr. Hugh Wormald tells me he has at the present moment a cock which will not allow him to approach the hen when she is sitting. Cock Pheasants, too, have often been seen attending broods of young birds, so that on the whole man has something to do with the indifferent marital relations of the species. J. B. D., writing in the Field (June 20, 1908), records curious behaviour on the part of a cock Pheasant, who persistently entered some coops where domestic hens were sitting on Pheasants' eggs and bullied them off the eggs.

About the end of March the cock Pheasant begins to display before the wife or wives he has gathered. ${ }^{2}$ The show is a very beautiful one, the cock exhibiting in the most perfect manner the full glories of his brilliant plumage. At this season the usual walk is seen to be more reserved and dignified, and the whole of the feathers are held out so as to give the bird a puffed appearance; the brilliant scarlet patch of skin round the eye is inflated and lowered beyond the angle of the jaw, and the purple ears erected and inclined outwards. ${ }^{3}$ The bone-coloured bill is of a brighter hue, and the eye, especially in the Mongolian sub-species, very brilliant. Thus he proceeds, ${ }^{4}$ until the moment of show. The wing nearest the female is then lowered and extended, the scapulars dropped a little; the tail is also spread and turned over towards her, so that she may see its full beauty. The feathers of the rump are also opened as far as possible; the neck is lowered and curved, and the head slightly turned to display the extended eye ornaments. If the female walks coquettishly away, or picks about with apparent indifference, he is not annoyed, but walks ahead to stop her and displays the other side of his person.

Young cocks begin to fight in September, and when full grown in October and November, may often be observed battling for an hour at a time in some open spot. They crouch and fly up suddenly, each endeavouring to strike the other on the head.

\footnotetext{
2 See Field, July 5 and 19, 1892, also many other instances in Tegetmeier's Pheasants, Zoologist, \&c.

In a wild state we seldom see more than three hens with a cock. Breeders find that from four to six hens are the best number to place with a male.

3 Mr. Wormald has a male which constantly carries the ear-tufts at right angles to the head at this season.

" "Proceeds" is perhaps the correct word. It is magnificent and dignified. A policeman never walks or "runs," according to his own account; he always proceeds to the spot.
} 


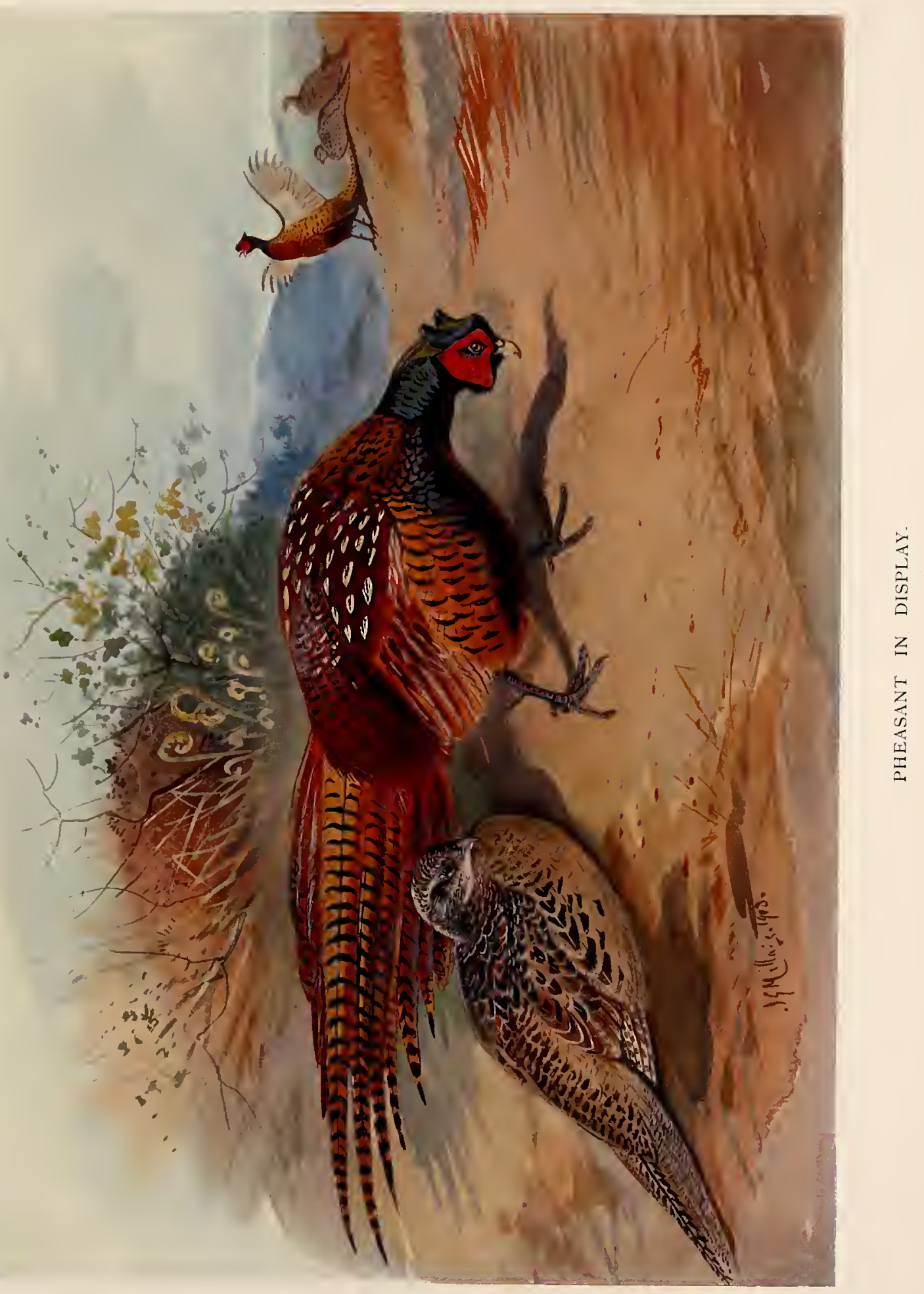




\section{The Common Pheasant}

They also strike downwards with their spurs. Adult cocks in spring do not fight for so long as young ones, owing to their inflicting harder blows, and one or the other soon gives way. Although armed with not inconsiderable weapons, they seldom kill each other, but individual males are often very savage with the females, spurring them along the back until they are literally torn to pieces. Sometimes cock Pheasants kill their hens with a single blow of the spur at the back of the skull, but this is rare, except in the case of Reeves's Pheasant, who is a regular Bluebeard in this respect.

As early as the end of March, but more commonly in April or May, according to latitude and weather, the female makes a slight depression in the ground, and usually lines it with leaves. The nest is generally under some slight protection, such as a thin bush that will throw a dappled shadow, so that the plumage of the bird when sitting may be unnoticeable. Often it is placed in thick covert and sometimes quite in the open, without any concealment. In this hollow she deposits from eight to twelve eggs of a greenish brown or greyish green tint; size in length, $I_{\frac{5}{6}}$ in. by $I_{\frac{3}{12}}$ in. in width. The period of incubation is twenty-four days. The cock may stay about and join the hen when she comes off the eggs during the period of incubation, and he may even sit on the eggs on rare occasions, and take some small part in the rearing of the offspring; but this is rare, except in places where Pheasants are scarce. Where they are numerous, he leaves her for good as soon as she begins to sit.

Gamekeepers as a rule are more fond of "egging" than any other occupation in their profession. Perhaps they never get over the schoolboy habit of the joy of nesthunting. They begin to look for Pheasants' eggs about the Ist of April. In pens some pampered female may lay an egg or two in March, but it is not usual to find a wild Pheasant nest with a fresh egg until the last week in April. A good keeper seldom searches his main coverts at this time, but wanders far afield along the roadsides which, if they have a southern aspect, are specially attractive to the birds. A man who knows his business soon learns to look, as it were, with the bird's eyes, and will with unerring instinct only search the spots where nests are likely to be placed. In a wood, hen Pheasants have an affection for pretty spots, carpeted with primroses, where recent tree-felling and barking has been going on, for they know that in such places there is always a greater abundance of insect life. If there are two hedgerows, the Pheasant will nearly always choose the one that gets most sun, and where banks shelve.

It is not generally known how readily Pheasants will lay in nests artificially made up for them, especially if they are rendered attractive by one or two dummy eggs. This practice of constructing nests often saves the keeper much labour-in fact, far more than the trouble of making sham nests. The system does not apply to places where the birds are left to rear their own broods, but only where it may be used as a decoy place for the gathering of eggs. The readiness of the hen Pheasant to lay in any sort of cavity of a suitable size is well known. Their occasional adoption of old nests placed in trees has already been referred to, whilst an extraordinary instance of a hen Pheasant's careless habits is thus given in Country Life, May 18, 1907:-

"A very remarkable instance of their indifference and carelessness in this regard has been told us by a correspondent, and it is singular in itself, as well as by way of illustration 
of this peculiarity of the pheasant. This case in point was one in which a pheasant was found sitting on a blackbird's nest built in a low thorn bush. At the time of the keeper finding the hen pheasant thus sitting, there were young blackbirds, already hatched, in the nest, and on the ground beneath was a single pheasant's egg. The explanation of this extraordinary spectacle may be left to the reader's ingenuity of conjecture. It has been suggested that the pheasant laid in the blackbird's nest, and that the proper owners ejected the immense intruding egg; or, again, that while sitting in the nest the pheasant laid the egg over the edge. Whatever the explanation may be, the fact is singular enough, and is perfectly well authenticated. Instances are not wanting of pheasants laying in wood-pigeons' nests placed in low trees, so that the blackbird and pheasant incident is not altogether without parallels."

In cold and backward springs Pheasants are often checked in their egg-laying early in May. This is especially the case in Scotland and the north of England. Pheasants' eggs do not seem to stand $15^{\circ}$ or $18^{\circ}$ of frost as grouse eggs will do, and any exposed to this low temperature are usually cracked and frozen. If wild Pheasants which have laid six or eight eggs are suddenly checked by a cold wave, they will lay no more, but commence to sit.

Two hen Pheasants often share the same nest. As many as thirty eggs have been found together, and instances of partridges and Pheasants laying in the same nest are very common. A hen Pheasant has been known to lay her eggs in the nest of a wildduck, ${ }^{1}$ common fowl, corn-crake, capercaillie, greyhen, and grouse. Young Pheasants and partridges may often be seen in one common brood in September. There are also many records of hen Pheasants using the deserted nests of owls, hawks, woodpigeons, and squirrels, and hatching their young in them. Both in this case and that of young wild-ducks born in similar situations, the chicks fall to the ground apparently without injury. In Scotland it is not rare to find hen Pheasants sitting on eggs as late as September. I once flushed a Pheasant from a potato field in mid-September, which rose off a nest containing ten eggs, and newly hatched young ones have been noted as late as October.

Mr. Wormald writes :-

"Our head-keeper, a very observant man, witnessed a curious incident this spring (1909). He saw a hen pheasant lay an egg in the middle of one of the pens. Instantly the bircl turned round and began poking it about with her beak. The keeper, thinking she was going to suck the egg, watched her carefully. To his surprise she started rolling the egg along to the side of the pen, and eventually pushed it under the corrugated iron fence into the open field. He then picked up the egg and replaced it on the spot where the hen pheasant had laid the egg, when she again repeated the performance."

On the food habits and general growth of young Pheasants little need be said, as all details on this subject are too well known both by sportsmen and naturalists to require description.

Many birds, such as water-hens, black-headed gulls, certain owls, \&c., are of a jealous and vengeful disposition towards the young of other species; but it is rare to find any birds except wild ducks, which always kill any weaklings of their broods, 
attacking their own young, except in cases where they are unable to release them from difficult situations. It is, however, well known that hen Pheasants will often kill their chicks as soon as they are hatched.

Mr. A. R. Micklefield of Stoke Ferry, Norfolk, who has had a lifelong experience among Pheasants, tells the following story:-

"Young pheasants were constantly being picked up dead on his rearing field near the coops, from no obvious reason; so watch was kept, and an old barren hen pheasant was detected in the act of pecking them on the head. The assassin was shot, and the deaths then ceased."

Domestic hens, too, will often kill young Pheasants placed under their charge. A correspondent in the Field, June I3, I908, writes:-

"I have put down this year about 2000 pheasant eggs, and the hens have hatched off as well as usual, averaging from thirteen to sixteen chicks each out of eighteen eggs in the nesting boxes. Only two hens hatched out seventeen out of the eighteen eggs, and it is a curious fact that both hatched off on the same day, and each hen immediately killed thirteen out of her seventeen live chicks by pecking their brains, and laid them in a row in front of her, each exactly in the same way. I shall be glad to know whether such a singular case has ever been noted before."

The hen Pheasant has a curious habit as she comes off the nest, having just laid an egg. She walks along flicking bits of grass from side to side, throwing them over her back. Mr. Wormald tells us that he has seen wild ducks and reeves (female ruffs) do the same thing.

Even after centuries of hand-rearing, the Pheasant declines to be anything but what it is, a wild bird; and its wildness is apparent immediately it is released in field or cover. Individual birds, generally those that have suffered some injury, have been tamed until they have no fear of man, and are even apt to be troublesome, owing to their courage and familiarity.

Mr. W. O. Meade-King gives an interesting account of a tame cock Pheasant in the pages of Country Life:-

"My father put a sitting of pheasant's eggs under a hen," he says, "three years ago, of which this bird is the only surviving child, and owing to a slight malformation in his back he has rejoiced in the name of 'Humpy' all his life. Of any place in which he is living for the time being he takes absolute possession. Just at present he is lording it in the shrubbery near the house, and if any one dares to walk through the shrubbery he attacks them furiously; dashing backwards and forwards over their feet, pecking their boots and beating them with his wings and claws; luckily his attacks are confined to this low level. At one time he took possession of the kitchen garden, a happy hunting-ground for him, it being a good size, over an acre, and surrounded by a high wall. Here he was particularly pugnacious, but never followed one out of the garden; as soon as the intruder reached the door he would fly up on to the top of the wall, crow a crow of defiance, and then fly down again ready for the next comer. He knows my father well, and always comes when he is called; but gratitude for the food given him every day is a negligible quantity; nevertheless, he sees in my father a protector. He does not approve of guns or dogs, and last year, when my father and two friends were shooting partridges. the two latter undertook to walk a stubble-field, while my father waited for 
them in the shade of a tree in a neighbouring field. No sooner were the guns in the stubble than Humpy flew out of the field over the hedge and straight to my father, by whose side he sat quite contentedly until the guns had left his own particular field. In spite of his extraordinary temper he is, as may be supposed, a great pet, and, after all, some excuse may be made for him, for one fine morning this last spring he turned up with seventeen wives; where he got them from nobody knows, but I should imagine that sort of thing might be calculated to try even the temper of a cock pheasant."

Pheasants thrive best on light sandy soils, and are found to increase in such counties as Norfolk, Suffolk, Cambridgeshire, Lincolnshire, Hants, Sussex (forest land areas), and Surrey, even when left to themselves. In Scotland parts of Perthshire seem to be the only county where the conditions are perfectly suited to wild Pheasants; but there are a few places in Forfar, Wigtown, Aberdeen, and Morayshire where they thrive without artificial additions. Every year a larger number of Pheasants are reared in Scotland, for it is found that they do almost as well there as in England on the light soils. It has been found that cold winters have little effect upon them, provided food can be found. Pheasants can survive the severest winters in remote Highland glens, and in the hanging woods of birch and fir they often afford far better sport than in the flat coverts of the South. In fact, wherever cover is to be found in Scotland, Pheasants will thrive and breed, and greatly add to the attractions of the North when the season of grouse and deer has ended. Highland proprietors are now finding this out, for it causes tenants to prolong their stay to a period extending to October, November, and December, when Scotland is often at its best.

The number of Pheasants the woods of such estates as Merton, Elvedon, and Brabraham can hold is truly astonishing. I saw 3000 head (2000 Pheasants) killed in one day in 1884, when Lord Cadogan had the shooting. Since that time 3000 Pheasants and more have been killed in a single day on other estates.

"In order to render useless all attempts of the nocturnal poacher to destroy the pheasants," says Waterton, "it is absolutely necessary that a place of security should be formed. I know of no position more appropriate than a piece of level ground at the bottom of the hill, bordered by a gentle stream. About three acres of this, sown with whins, and surrounded by a holly fence to keep the cattle out, would be the very thing. In the centre of it, for the space "of one acre, there ought to be planted spruce fir trees about i 4 feet asunder. Next to the larch, this species of tree is generally preferred by the pheasants for their roosting-place; and it is quite impossible that the poachers can shoot them in these trees. Moreover, magpies and jays will always resort to them at nightfall; and they never fail to give the alarm on the first appearance of an enemy. Six or seven dozen of wooden pheasants, nailed on the branches of trees in the surrounding woods, cause unutterable vexation and loss of ammunition to these amateurs of nocturnal plunder. Small clumps of hollies and yew trees, with holly hedges round them, are of infinite service, when planted at intervals of one hundred and fifty yards. To these the pheasants fly on the sudden approach of danger during the day, and skulk there till the alarm is over."

Poachers employ every sort of device with net, gun, air-gun, rifle, and catapult to destroy Pheasants, and it must be admitted that it is a very great temptation to poor men, cursed or blest with sporting instincts, to see swarms of these birds frequenting the roadside, and positively asking to be killed. For this reason many kind-hearted 


\section{The Common Pheasant}

people refuse to preserve Pheasants, from motives we must respect. I know of one practically noiseless weapon with which thousands of Pheasants could easily be killed, and it is now being largely employed in killing grouse in Scotland, with little fear of detection, but it is not necessary to mention it. Poachers are usually men of considerable cunning and intelligence, such as we find in the eastern and north-eastern counties, for very little poaching takes place in Sussex, Wiltshire, Hants, \&c., where the peasants are slow-witted and wanting in originality. A good preservative for Pheasants is to give them plenty of conifers; spruce and silver firs are the best to roost in, and it is then most difficult for a poacher to espy the sleeping birds. Nearly every species of vermin, four-footed and winged, preys upon Pheasants. The principal mammals that feed on Pheasants are domestic and wild cats, foxes, pole-cats, stoats, weasels, and rats. The last named prey chiefly on the chicks and half-grown birds, and can do endless damage amongst the coops unless killed. Domestic cats, especially halfbred Persians, are most inveterate hunters once they take to the woods, which they are apt to do when they have kittens, and will kill hen Pheasants in their nests as well as destroying young birds. The fox will live exclusively on Pheasants and rats if he is not well supplied with rabbits, and most owners who are anxious to preserve foxes and Pheasants now know that it is absolutely necessary to have a good stock of rabbits if his Pheasants are to escape. The time foxes do most damage is in August and September, when the half-grown Pheasants roost in the long grass along the covert edges, and I have known a fox to kill fifty in two nights at this time. They are also most destructive if they can enter a wired enclosure where hens are kept for laying, and will kill all they can for the mere sake of slaughter. Rats are perhaps the worst vermin of all, because they not only destroy eggs and young, but they make endless runs under coops and in banks, which are subsequently used by weasels. The latter, unless confirmed bird-killers, seldom do much damage, unless they have some place of retreat close at hand, such as rat or mole runs. They will seldom go out to coops placed in an open field, unless they have some hole into which they can dive and drag their prey. I have somewhat of an affection for the little "mouse-hunt," which on the whole does far more good than harm, but the keeper will never discriminate between the individual sinner and the virtuous race. Ninety-nine times out of a hundred, if we watch the weasel closely, he is hunting and killing voles, mice, and half-grown rats, and it is the exception when one is found killing young Pheasants.

Considerable destruction to Pheasants' eggs is effected by crows, rooks, jackdaws, jays, magpies, and other egg-eating birds. The case of the rook is similar to that of the weasel, but whole communities of rooks have become confirmed egg-stealers if the individuals who first started the practice are not shot. It is not just, however, to brand innocent communities, which are on the whole decidedly good, for the errors of a few, for the benefits to agriculture conferred by the rook are of greater importance than a few Pheasants' eggs. Curiously enough, rooks have become more persistent hunters of eggs than formerly, especially in the open districts of Scotland and Ireland. I know of certain places where not one plover's or exposed Pheasant or partridge's nest escapes. They hunt the fields and moor edges as carefully as any pointer, and I 


\section{2 \\ The Natural History of British Game Birds}

have known a rook to hunt certain lines of hedgerows for small birds' eggs with great regularity. This same bird took a lark's nest situated in the grass five yards from my drawing-room window, and came always to my garden before eight o'clock every morning until I shot him. Rooks will even kill and carry off young Pheasants. The following instance ${ }^{1}$ will show :-

"On June 13th my keeper observed about half-a-dozen rooks engaged amongst the coops of young pheasants, and, suspecting their object, drove them off. The next morning, having fed and watered the young birds, he went to his cottage, and, looking out about six o'clock, saw a strong detachment of rooks from a neighbouring colony in great excitement amongst the coops. He ran down, a distance of two hundred yards, as fast as possible, but before he arrived they had succeeded in killing, and for the most part carrying off, from forty to fifty birds two or three weeks old. As he came amongst them they flew up in all directions, their beaks full of the spoil. The dead birds not carried away had all of their heads pulled off, and most of their legs and wings torn from the body. I have long known that rooks destroy partridges' nests and eat the eggs when short of other food, but have never known a raid of this description. I attribute it to the excessive drought, which has so starved the birds by depriving them of their natural insect food that they are driven to depredation. It will be necessary to be on guard for some time; bad habits once acquired may last even more than one season. Probably the half-dozen rooks first seen amongst the coops tasted two or three, and, finding them eatable, brought their friends in numbers the next morning."

In Scotland, the chief winged enemy of the game preserver is the hooded crow. They are relentlessly hunted, but a few manage to escape and nest in the dense fir woods in spite of the vigilance of keepers. What one family of hoodies will do is instanced by Mr. Ogilvie Grant: ${ }^{2}-$

"I was passing through a Scotch fir plantation forming part of a large estate in the north of Scotland, where thousands of pheasants are annually reared and turned down. The plantation ran along about a hundred feet above the rocky sea-coast, and as we advanced along the slippery path, we found several sucked pheasants' eggs, evidently the work of crows; nor had we gone far before we came suddenly upon a whole family of hooded rascals, five young and two old birds. In the course of about a quarter of a mile we counted over a hundred empty shells, which had evidently been carried to the path and there devoured. How many more might have been discovered had we searched it is impossible to say, but we saw ample evidence of the wholesale destruction which a family of crows is capable of committing among pheasants' eggs."

Nearly the whole of the Falconidx will prey upon Pheasants; the common buzzard, the goshawk, and the sparrow-hawk being the worst offenders; although the two former are now so rare as to be of no consequence. I have known two instances of the tawny owl killing numbers of young Pheasants. One summer our head keeper at Murthly reported to me that he had missed many young Pheasants, always in the evening. He saw a tawny owl take two on separate occasions. The bird was so cunning that the keeper could not obtain a shot at it for some time, but at last he killed it in the act of carrying off a well-grown chick. He sent me the culprit with its victim still embedded in its claws.

Water-hens will sometimes kill young Pheasants. In the case of the latter I think 


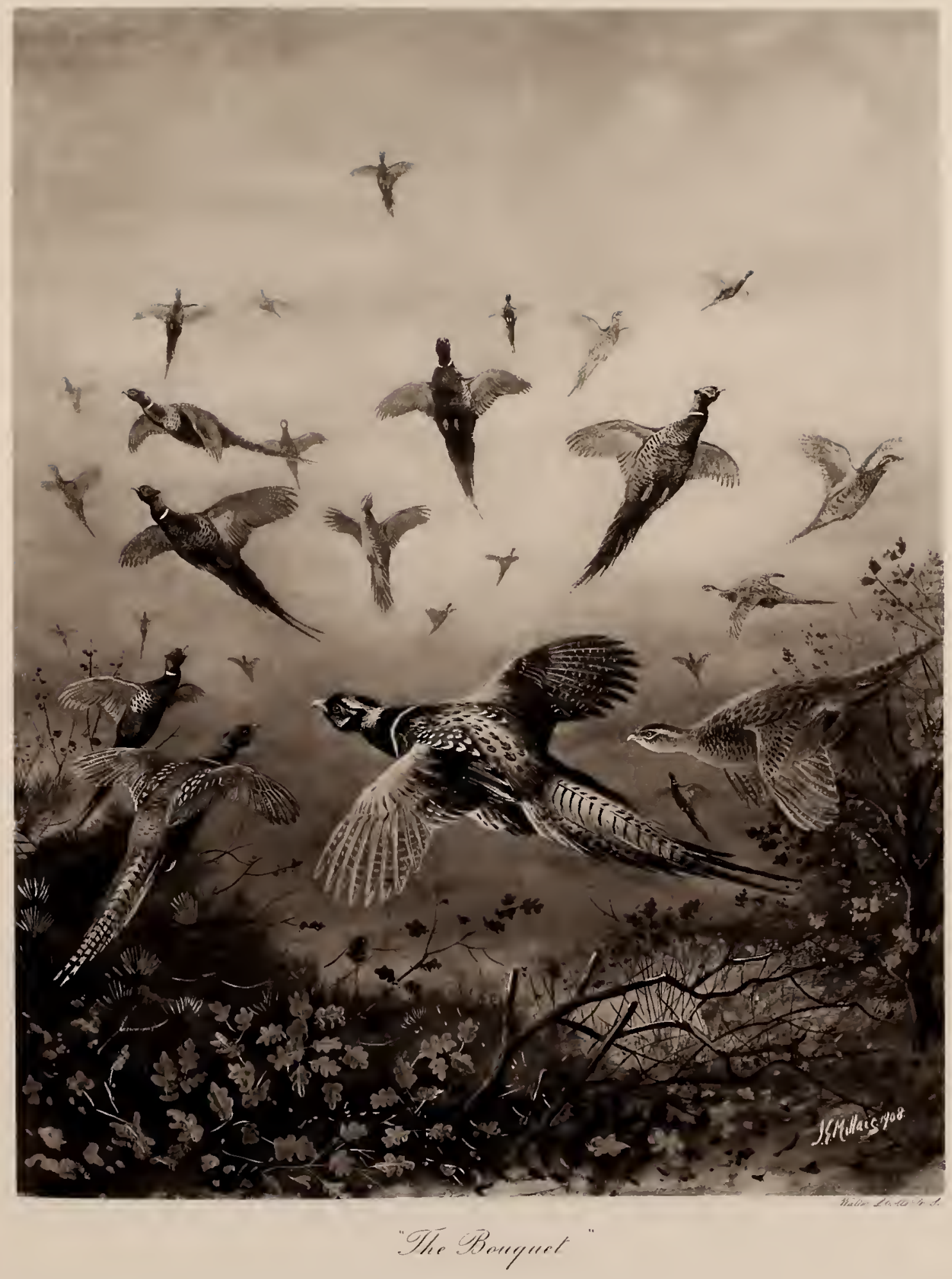





\section{The Common Pheasant}

it is nearly always the male who does the murder, for he is of a very savage and jealous disposition during the breeding season. I have seen cock water-hens attack and drive off any birds that come near their broods. They will even rush at and pcck a swan. The kestrel is a much maligned bird, but as in the case of the rook and the weasel it is again the individual only that is the culprit. A young Pheasant running in the grass must be very like a vole, so that we are not surprised if the little falcon sometimes makes mistakes, even when they are done on purpose. On the whole, kestrels may be said to do little harm and a great deal of good. ${ }^{1}$

With all the details concerning the management of Pheasants in aviaries, and the rearing of young birds in the open, the naturalist has little to do, whilst elaborate instructions on the subject are to be found in many excellent books, notably Tegetmeier's Pheasants, and in the pages of the Field and Country Life. Pheasant shooting also and the management of coverts are subjects which have already been treated ad nauseam. To be successful, a man must have practical experience. Books and papers will give many excellent hints, but they can do little compared with the knowledge gained in the fields of practice.

Pheasants are liable to a variety of diseases which are, for the most part, due to overcrowding in unsuitable surroundings, in-breeding, ill-drained soils, wet seasons, \&c. When diseases begin they soon become infectious, and rapidly spreading will sometimes kill off most of the young stock. "Gapes" is due to the presence of small redworms (Syngamus trachealis) which infest the windpipe. The life history of these gapeworms has been fully described by Dr. Spencer Cobbold and Mr. Theobald. It is a very catching disease, as young fowls, Pheasants, \&c., will be attacked if they feed on soil where the ova of the worms are present. There are various remedies for the disease, which are fully described in Tegetmeier's Pheasants (p. 135). It is not generally known that "gapes" are communicated from field to field by sparrows and starlings. Another common disease, known as the "cramps," has been fully described by Professor Klein. The young bird is usually attacked in the second or third week of life. The disease commences with lameness in one leg, next day the other leg is affected, and the bird sits motionless. When this occurs on the third day, on examination the thigh bones or legs are found to be soft or even broken, with great extravasation of blood. Microscopic examination shows that the interior of the bone is highly inflamed by the presence of bacilli, which Dr. Klein asserts are highly infectious. The only cure seems to be to destroy and burn young birds so affected, and to remove coops to higher and drier ground. A very full description of this disease was published by Dr. Klein in the columns of the Field.

Another disease which carries off many Pheasants and partridges is fowl enteritis, which is too well known to be described. This, again, is due to rearing Pheasants on ground where fowls have been for too long. There is now a practice, both in the eastern counties and in the Midlands, of putting fowls out in houses in the open stubbles. This is often a fatal source of spreading disease amongst both partridges and

\footnotetext{
1 "This season" (1gog), writes Mr. H. Wormald, "the Kestrel has done much damage in Norfolk. I know of three 'rearing' fields at various distances, from 5 to 15 miles apart, where these falcons have caused much havoc amongst the young Pheasants."
} 


\section{The Natural History of British Game Birds}

Pheasants, for if chickens die and the ground once becomes a harbour for the bacillus of enteritis, it may take years before it recovers. I have recently been shooting in the Midlands, where the stock of partridges has been reduced by one-half, whole coveys being found dead in August, owing to this cause. "Scurfy legs" is another disease common amongst Pheasants and fowls. It is due to a parasite (Sarcoptes mutans), which spreads quickly unless checked at once. Pheasants have also been known to die from leadpoisoning, due to swallowing shot picked up in the coverts, but such cases are rare, as well as poisoning by the eating of yew leaves.'

It has been discovered recently that numbers of Pheasants die from a form of epidemic pneumonia. On examining a bird which had died of this disease, Dr. Sambon discovered a protozoal organism closely resembling the Leucocytozoon lovati. This new protozoa was described by Dr. Sambon as Leucocytozoon macleani (see Field, September 28,1907$)$. The birds attacked seem to die in a few hours; one game-rearer having lost 1500 in a very short time. Dr. Louis Sambon and Mr. H. Hammond Smith thus describe the disease in the Field (July 4, I908):-

"The disease seems to make its appearance, not only on ground which has been used before for rearing pheasants, but also on ground which has never before been used for that purpose. Both in the pheasants and in the partridges the pathological appearances were the same. The trachea contained a quantity of blood-stained serous fluid. The lungs, either in whole or in part, presented the typical characters of pneumonia; in some cases both lungs were involved, in others only one. The liver in some cases showed fatty degeneration, and was of a yellow-ochre colour. In these cases there were symptoms of diarrhœa. Bacteriological examination showed in all cases an organism exactly similar in morphological and cultural characters to the diplococcus or pneumococcus of Fraenkel, a bacterium now regarded as the most frequent, if not the sole, cause of genuinc acute lobar pneumonia in man.

"In the pheasant the diplococcus was found in large numbers, both in the serous fluid from the bronchi and in the consolidated lungs. It is a small, roundish, oval, or flame-shaped coccus about $I \mu$ in longest diameter, but varying somewhat in size. It occurs as a rule in pairs (diplococcus), with broader ends in apposition, and the paired elements may be either equal in size or one larger than the other. A wide, halo-like zone, the so-called capsule, surrounds each organism or pair. This capsulc has a sharply defined external margin, is round when enclosing a single coccus, and ellipsoidal when containing a pair of cocci. Occasionally the two elements of a pair are situated at the opposite poles of the capsule, a space intervening between them. In the pulmonary exudate empty capsules are frequently met with. The organism stains readily with the basic aniline dyes, and retains the stain in Gram's method. Its cultural characters appear to be identical with those of Fraenkel's diplococcus.

"In a few cases the diplococcus was the only organism seen in film preparations made from pneumonic lung, but in the majority of cases, and especially in birds that had been dead some timc, it was found together with putrefactive and other secondary bacteria. Amongst the latter the most frequent was a capsulated bacillus in every way similar to Friedländer's pneumobacillus, an organism also regarded by some bacteriologists as a possible cause of lobar pneumonia. The capsulatcd bacillus found in the pheasant measures from $1.5^{\mu}$ to $3^{\mu}$ and even $4^{\mu}$ in length by about $I \mu$ in breadth; it has blunt, rounded ends, and occurs frequently in pairs, occasionally in long rod forms, always surrounded by a wide hyaline zone of mucus-like substance. It stains readily with the basic aniline stains, but loses the stain in Gram's method. Its cultural

I At Abbotsbury, Dorsetshire, in 1894 , Lord Ilchester had a clipped yew hedge in his garden cut down because Pheasants died from eating the leaves as they sat on the top of it. Several other cases of yew poisoning in Pheasants have been reported from time to time. See the Field, Nov. 25,$1876 ;$ Dec. 2 and 23,$1876 ;$ Dec. 20,$1890 ;$ Sept. I7, 1892 ; Nov. I 1,1893 


\section{The Common Pheasant}

characters appear to be idcntical with those of Fricdländer's pneumo-bacillus. Stab cultures show the characteristic 'nail-like' appearance. Inoculation experiments with both organisms will be carried out as soon as possible.

"Together with the pneumonic birds, others were sent to us as having dicd of the same disease, but presenting numerous gapeworms (Syngamus trachealis) in their trachea. Gapeworms were seldom found in the trachea of the pneumonic birds, which were for the most part very young; but the possibility of an earlier laval stage of the gapeworm in the lungs was considered a possible means of favouring the pathogenic action of thc diplococcus, and, indeed, one of us (Dr. Sambon) has now found immature forms of Syngamus trackealis in the lungs of both the red grouse and the pheasant.

"Other worms were occasionally found in the intestines of the older birds, but they have no relation with the lung affection. The prcsence of the diplococcus suggests that these birds died of an acute infectivc pneumonia, which is probably spread from bird to bird by means of the mucus found in their trachca being coughed up and expectorated or sncezed both on to the food they eat and into their drinking water.

"In our prcsent knowlcdge of this disease all measures to mitigate its fatal results must be prophylactic. All affccted birds should be at once killed and burnt; the healthy birds should be put on to fresh ground and carefully watched, and birds suffering from gapes should likewise be destroyed. The coops should be thoroughly disinfccted. It might be of service to give all the birds a small amount of salicylate of soda in their drinking water; a 1 per cent. solution would suffice."

It seems a great pity that we do not possess in England a properly qualified practitioner associated with a good scientific ornithologist, and appointed by the Board of Agriculture to inquire into the diseases of birds that are useful to mankind. In America they are far ahead of us in this respect, and have been working industriously on the subject for twenty years with excellent results. Such a suggestion is made by my friend Mr. W. S. Pycraft, in a contribution to Country Life (July 21, 1906), in which he describes the results of examination of Pheasant chicks which were supposed to have died of enteritis :-

"During the past thrce weeks the death-rate among pheasant chicks has, on many game farms, reached an appalling total. As usual, so far as I can make out, the cause thereof is attributed to cnteritis, but this diagnosis, it would seem, must be accepted with some reserve. At any rate, post-mortem examinations, which I have just made on a dozen birds sent me from a game farm in Sussex, have convinced me that enteritis, at all events in a considerable number of cases, is not the causc of death; though, lacking a properly equipped laboratory, I am unable to say whether some other form of bacterial infection is at the bottom of this mystery, or whethcr these outbreaks are due to blood parasites-trypanosomes-though this last supposition has so far received no support. It may be that the mischief comes from quite another and unexpected source, since I made one discovery that will possibly prove of some importance. In short, it may turn out that a large percentage of deaths are due to myiasis, caused by the flesh-fly (Sarcophaga camaria). At any rate, in most of the birds of this batch I found a living larva, apparently of this species, lodged in the posterior nares-the slit along the roof of the mouth. It would be of great interest, and of considerable help, if those now engaged in rearing pheasants-especially those suffering such heavy losscs-would make careful observations as to the prevalence of this fly among their coops. It is a large insect, bigger than a 'blue-bottle,' and having its abdomen chequered after the fashion of a draught-board. Furthermore, it is peculiar in that it is ovoviviparous, so that the small and active larva could be easily deposited in the nostril of the chick, whence it would quickly make its way to the back of the nasal chamber. It is quite possible, of course, that this parasite may not, after all, 


\section{The Natural History of British Game Birds}

cause death, but its presence, at any rate, cannot but be most harmful and most dangerous to birds at any age, and especially to chicks. Thus every possible means should be tried to eliminate this pest from the breeding ground."

The points raised by Mr. Pycraft are of great importance to game-rearers; but there is no one to undertake the investigations, unless some disinterested individual can be found who is willing to give years of work for no pay and little thanks.

Disease of the ovary is fairly common amongst Pheasants, and is due to various causes which have not yet been fully established; but the results are of interest, as the hen Pheasant invariably assumes the plumage of the male in some degree. Complete destruction or injury by shot will have similar results. Mr. Tegetmeier, who has studied Pheasants closely, goes so far as to say: "In some cases it (the assumption of the male plumage) is absolutely entire." This is quite an incorrect statement. I know of no example whose plumage can be said to be quite the same as that of a male, nor can I believe that Mr. Tegetmeier has ever seen one." The most "advanced" females in this respect are always less strongly barred and looped on the breast and flanks, and the rump and back are never, so far as I know, wholly free from hen feathers. The green crown of the head, too, is usually intermixed with sandy and black feathers, and the scarlet papillar patch round the eye is almost invariably absent. ${ }^{2}$ In the most complete public and private collections of these islands I have not come across a single specimen of a hen assuming male plumage that was quite like a cock, nor one in this abnormal plumage which had other than rudimentary spurs.

The phenomenon may be caused by loss as well as by disease of the ovary-in fact, any injury to this part will cause the bird to change in accordance with the proportion of the damage. We see hens with a russet tint pervading the breast. Those more advanced will often show very red feathers on the flanks often of composite form and colours between the two sexes; others will exhibit black and purple about the upper neck, and so on till we find an extreme example in such an advanced state of cock's plumage as I have already indicated. Many will have very fairly complete white rings round the necks, and even grow longer tails than usually seen amongst hen birds.

These abnormal females are invariably barren, ${ }^{3}$ and generally more than one year old. There is a popular idea amongst sportsmen and gamekeepers that they are always old birds, but this is not the case, and I could give many instances to show that firstyear birds often assume the phenomenon on acquiring their first adult plumage, some of them quite as completely as old hens ever do.

I have dissected five or six of these barren hens, and have found that in two cases the ovary was dried up, small, flat, and black; in other cases it was flaccid and full of mucus, and in another the ovary had disappeared and in its place two No. 6 shot dropped out. I have no medical knowledge to give an opinion on any disease that may affect the birds apart from injury by shot.

\footnotetext{
1 A photograph of what is claimed to be a female completely assuming the plumage of the male is given in the Field, August 7 , $19 \circ 9$, but I agree with the editorial remark that the specimen in question is probably a spurless cock.

2 A female with half-cock plumage and a perfect scarlet papillar patch round her eye was shot by Mr. J. A. Jones at Charlwood Park, Surrey, October 18, 1887. Mr. Jones sends me a sketch of the bird. The sex was ascertained by Rowland Ward. There were no dots of purple feathers round her eye.

3 With the exception of young hens with a russet tint and spurred females. Both of these frequently lay fertile eggs.
} 


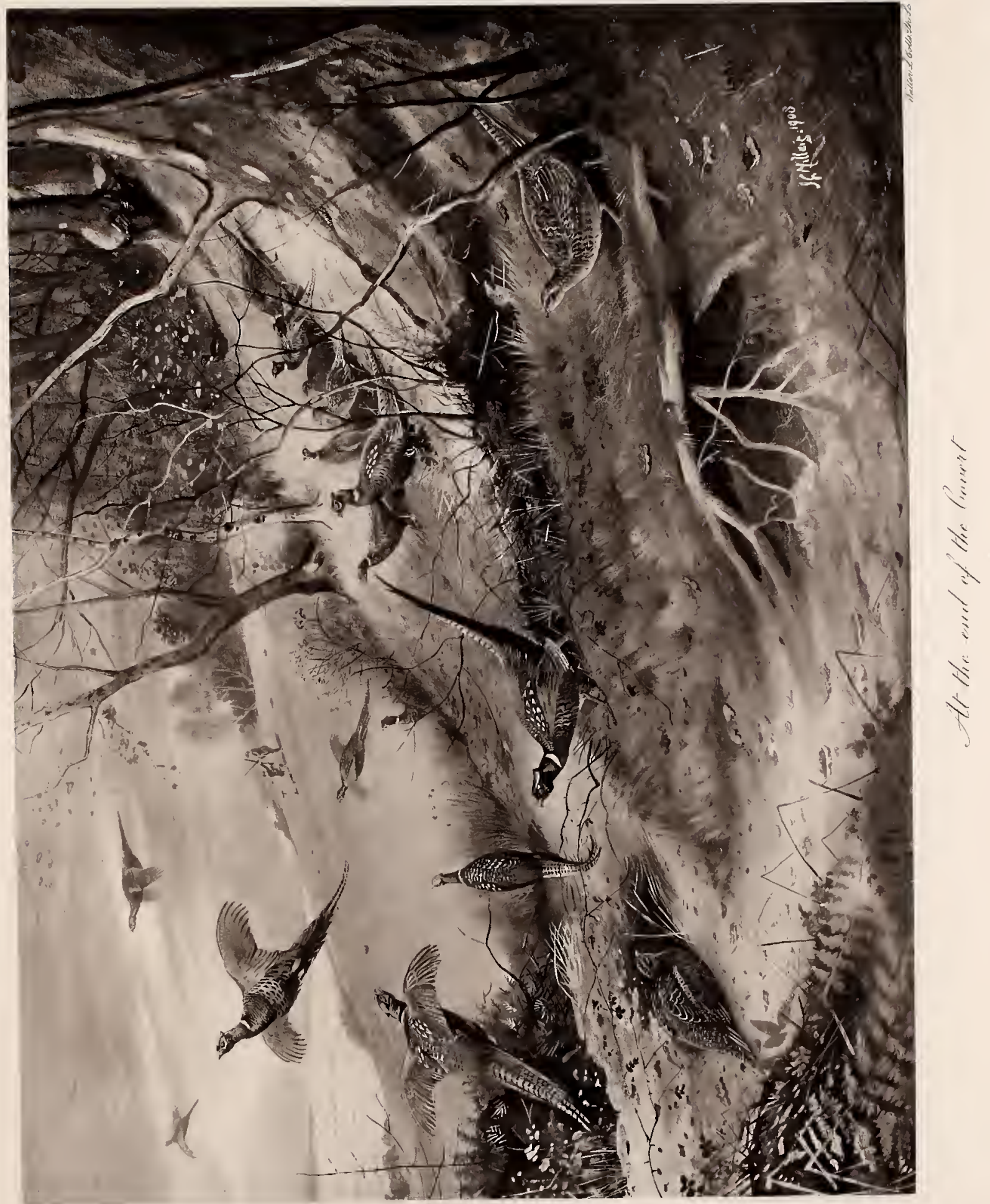





\section{The Common Pheasant}

We should expect such females to grow spurs, but "spurred" females, which are rare, are more often found amongst what seem to be perfectly healthy birds. ${ }^{1}$ The whole circumstance that various genera of birds, with healthy or injured ovarium and oviduct, ${ }^{2}$ should not only change the colour but the form of pattern of the feathers, is very remarkable, and has not yet been satisfactorily explained by physiologists.

The artificial breeding of gallinaceous and other birds always tends in time to produce variation, and from this rule the Pheasant is no exception. The steel-coloured variety known as the Bohemian Pheasant, in which the lighter parts of the feathers are grey-white, or yellow-tinted, is not rare, but sufficiently uncommon to be worthy of notice. These, with white and pied birds, are the only regular variations amongst Pheasants; for those in which the dark hoops and blotches in both sexes are half-coloured blue-grey, with the light parts white or grey, or in females yellowish, are extremely rare, although a few are known in public and private collections. I have seen four or five hen Pheasants sandy-brown all over with the dark marking a little darker than the rest of the plumage; but the most remarkable variety of a Pheasant I have seen was one I picked up in a poulterer's shop in Cambridge, near which town it was killed in 1884 . It was a hen assuming the cock's plumage with albinism as well. The whole of the upper part of the bird was a composite mixture of hen-cock and white plumage, extending to the tail. I exhibited the bird at the British Ornithologists' Club, and it was sold at Stevens with the rest of my albinoes in 1908 , so that I do not know its present owner.

No doubt a race of white Pheasants could easily be produced by pairing white birds together; but that white cocks also tend to produce pied or white varieties I doubt. Mr. Tegetmeier remarks that the absence of abnormal young birds is due to the reason that "white cocks are doubtless driven away from the hens by the stronger and more vigorous dark birds, and rarely increase their kind." With this view I entirely disagree. I have known two pure white cocks, one at Murthly in Scotland, which lived for nine years, and one at Warnham, in Sussex, for seven years. Both these birds got their complement of hens every spring, and were not known to have been the fathers of any pied or white progeny. The Warnham cock was in the aviaries for several years, and his progeny were of the normal colour, whilst on release he seemed to hold his own and pair with as much freedom as any of the other wild cocks.

$P$. colchicus has been known to hybridise with the common fowl, black grouse, and capercaillie. In the case of the first named, the crosses are exceedingly clumsy-we may almost say ugly birds-having none of the beauties of either parents. Pheasants seem to cross more freely with dark-plumaged fowls of the langshan, black hamburgh variety than others, but this may be purely accidental. Crosses with the speckled hamburgh are also common. The fowl with which the Common Pheasant will most readily interbreed is the game bantam. This we can readily understand. A correspondent in the Field (January 9, 1909) states that he has reared several such hybrids,

1 Mr. J. A. Jones, who has given much attention to game birds, informs me that he has a normally coloured hen with perfectly developed spurs. This he killed at the Rookery, Gatwick, Surrey, in October I883.

2 I possess a female redstart in more or less masculine plumage, which I captured on a nest containing four eggs in Suffolk, in June 1884 . 


\section{The Natural History of British Game Birds}

and one male hybrid which had its liberty paired with a domestic fowl. The eggs were, as is usual in such cases, infertile. The same writer paired a ring-necked cock Pheasant with guinea-fowl and Yokohama hens, but the eggs were infertile. This, however, by no means proves that such a result would always occur. On the contrary, I think that any one who wishes to do so could hybridise the guinea-fowl and Pheasant. Mr. Walter Rothschild has a remarkable hybrid between a guinea-fowl male and a pea-hen, and this instance, with my specimen of grouse and bantam cross, show that very diverse species will sometimes mate successfully. Mr. G. W. Murdoch (Field, January 23, 1909) states that the practice of breeding Pheasant-barndoor fowl crosses was not a common one in the time of Queen Elizabeth as some writers appear to think was the case. I have noticed that when certain species are fairly closely allied in form, habits, and time, and season of reproduction, the crosses are not invariably infertile. In the case of surface-feeding ducks, for instance, the product at the first cross, if mated with the same species as one of the parts or another closely allied, and given surroundings that are eminently congenial ${ }^{3}$-and that is seldom the case-will pair again, and so on ad infinitum, until a bird can be reproduced that is a fourth or fifth hybrid, with mallard, pintail, widgeon, and gadwall blood in its veins. I possessed several such crosses which were presented to me by Sir Richard Graham, who has with great patience and skill made the breeding of surface-feeding ducks a speciality. Breeders of birds are often without observation and try to mate any two birds of different sexes, and to obtain crosses between different species without considering the temperaments and inclinations of the individual male and female. In some species almost any healthy male and female will breed together, but this is rather the exception than the rule. Most birds, except purely polygamous ones, fall in love with each other in just the same way as human beings do, and for each sex it is not a case of any female or male. They are distinctly selective. I have seen ten teal or ten mallard in pens separated by a wire enclosure, and have noticed that certain drakes will have nothing to do with the ducks in their own pen, but will fall desperately in love with some charmer in the next pen, being quite insensible to the advances of others which are contiguous and desire to make love to them. The two that have taken a fancy to each other will sit for hours side by side up against the wire, gazing upon each other and whispering "soft nothings." In such a case it is well to allow these natural instincts, and two such birds are almost certain to pair successfully. Sir Richard Graham fully understands this, and has in consequence been more successful than any one with these birds. Thus first crosses take a fancy to second crosses and so on, although they do not select a mate quite so freely as pure-bred birds that are allowed complete liberty. To be successful in crossing birds that are "shy" to breed with one another, but have already paired, it is necessary to give them a run and pond all to themselves. Many people who have numbers of these surface-feeding ducks and other birds have written to me asking why the birds, which in many cases have paired, will never make a nest or lay. The answer is that it is constant disturbance by other species that is the cause. A duck or game bird once harried from her retreat when she intends to nest will never return to it. She lives in too much fear. One sheldrake or Egyptian goose will upset a whole colony.

\footnotetext{
1 This is essential.
} 


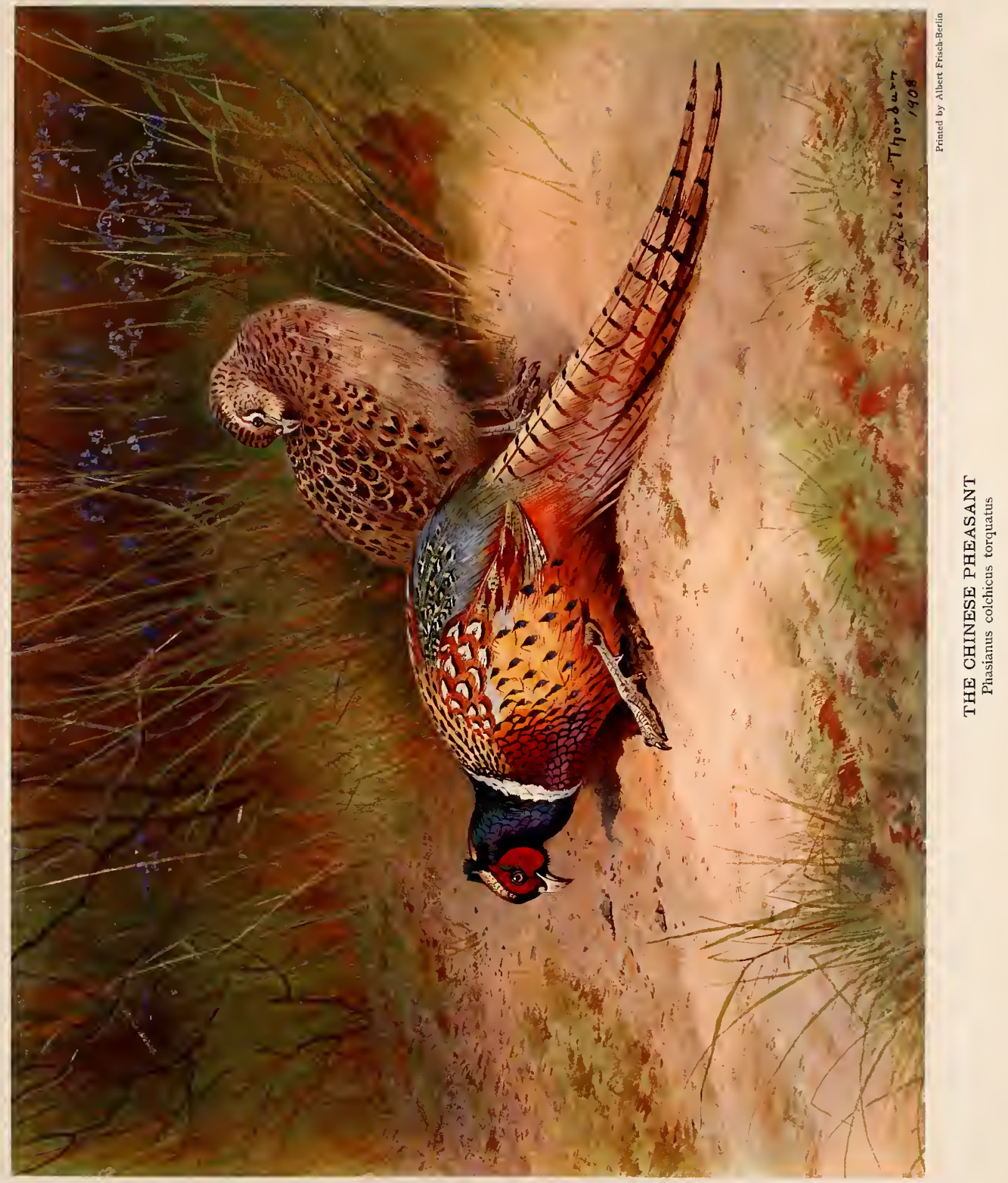





\section{The Chinese Pheasant}

After this digression we must return to our Pheasant-fowl hybrids. Mr. Tegetmeier is inclined to regard such crosses as sterile; but I do not, provided that a nearly allied mate, such as the species to which either parent belonged, is forthcoming, and that the female takes a fancy to so ugly a husband. A specimen of such a second cross seems to have occurred if we accept Yarrell's account (British Birds, 4th ed., iii. 101).

At a meeting of the Zoological Society, Sept. 27, 1836, a note was read from Mr. Fuller of Carleton Hall, Saxmundham, stating that in the previous year his gamekeeper had succeeded in rearing two birds "from a barn-door hen, having a cross from the Pheasant, and a Pheasant cock." The living birds, which Mr. Fuller presented to the Society, were exhibited at the meeting, with a hybrid between a Pheasant and a common fowl, one of several that had been for some years in the gardens. It .is stated in the Proceedings (1836, p. 84) that "the specimens of the three-quarterbred Pheasants were considered interesting, the opinion of the older physiologists having been that animals bred between parents of two distinct species were unproductive." Yarrell and Vigors took part in the conversation which followed, but no doubt was expressed as to the birds having been bred in the manner described by Mr. Fuller.

Sub-species of $P$. colchicus

\section{THE CHINESE PHEASANT}

\section{Phasianus colchicus torquatus (Gmelin)}

The following is the detailed description of the male and female as given by the late Mr. Gould in his monograph of the Birds of Asia:-

"The male has the forehead deep green; crown of the head fawn colour, glossed with green; over each eye a conspicuous streak of buffy white; the naked papillated skin of the orbits and sides of the face deep scarlet or blood-red, interspersed beneath the eye with a series of very minute black feathers; horn-like tufts on each side of the head; throat and neck rich, deep, shining green, with violet reflections; near the base of the neck a conspicuous collar of shining white feathers, narrow before and behind, and broadly dilated at the sides; the feathers of the back of the neck black, with a narrow mark of white down the centre of the back portion, and a large lengthened mark of ochreous yellow within the edge of each web near the tip; the feathers of back and scapularies black at the base, with a streak of white in the middle, then buff surrounded with a distinct narrow band of black, to which succeeds an outer fringe of chestnut; feathers of the back black, with numerous zigzag and crescentic marks of buffy white; lower part of the back, rump, and upper tail-coverts, light green of various shades, passing into bluish grey at the sides, below which is a mark of rufous; breast feathers indented at the tip, of a rich reddish chestnut, with purple reflections, and each bordered with black; flanks fine buff, with a large angular spot of beautiful violet at the tip; centre of the abdomen black, with violet reflections; under tail-coverts, reddish chestnut; wing coverts silvery grey; wings brown, the primaries with light shafts, and crossed with narrow bars of light buff; the secondaries similar, but not so regularly marked as the primaries; tail feathers olive, fringed with different shades of reddish violet, and crossed at regular intervals with broad, 


\section{00 The Natural History of British Game Birds}

conspicuous black bands, passing into reddish brown on the sides of the basal portion of the six central feathers; bill yellowish-horn colour; irides yellow; feet greyish white. The female has the whole of the upper surface brownish black, with a margin of buff to every feather; the throat whitish, and the central portion of the under surface fawn colour; flanks mottled with brown; tail buff, barred with dark brown, between which are other interrupted bars of the same hue. These marks are broader on the two central feathers than on the others, and, moreover, do not reveal the edge on either side."

Distribution.-All authorities are agreed that this is the common species of Pheasant to be found in South and Central China. It extends as far west as Szechuen. It is very abundant about Hankow, the country lying north and west of the Yangtze, whilst a slightly different variety with ochreous feathers on the flanks are found in large numbers in the island of Formosa. As long ago as 1513 it was introduced to the island of St. Helena by one Fernandez Lopes, who deserted from the Portuguese army at Goa, and it has remained there in its original form ever since. The Chinese Pheasant has been introduced with success into New Zealand, the United States, and British Columbia. In the two last-named countries it is regarded as a more vigorous bird than $P$. colchicus, for what reasons I failed to discover.

To England the Chinese Pheasant was introduced in small numbers early in the last century. It was not until the late sixties that any great change was observed in the purity of the old English stock of $P$. colchicus, when it was found that the Chinese birds had so increased and interbred with the residents that few of the latter remained in their original purity. On some few estates the new-comers were religiously excluded, but the wandering nature of Pheasants has defied isolation, so that the two types have become mixed beyond recognition. Within the last few years the other sub-species, the Japanese Pheasant $(P . c$. versicolor $)$ and the Mongolian Pheasant $(P$. c. mongolicus), birds of approved excellence and fertility, have been introduced in large numbers, so that in time the British Pheasant of the future will be a mixture of all four varieties.

Cross-bred birds of the true species and its allied races are perfectly fertile inter se, and so ad infinitum. The bird described by Consul Swinhoe as $P$. decollatus is doubtless a local variety of $P$. c. torquatus. It is said to have no ring round the neck, but to be otherwise similar. The first specimen came from Chung-king-foo in Szechuen, where my friend Mr. Charles Nix has recently found it. This traveller stated to me that he found pure types of the so-called $P$. decollatus in western Szechuen, as well as numbers with large and small white neck rings on the same ground, the birds on their eastern habitat grading into the pure type of $P$. c. torquatus found on the Upper Yangtze.

The Yarkand Pheasant (P. c. insignis) and Shaw's Pheasant (P. c. shawi), both geographical variations of the Chinese Pheasant, have not so far been introduced into Britain. 


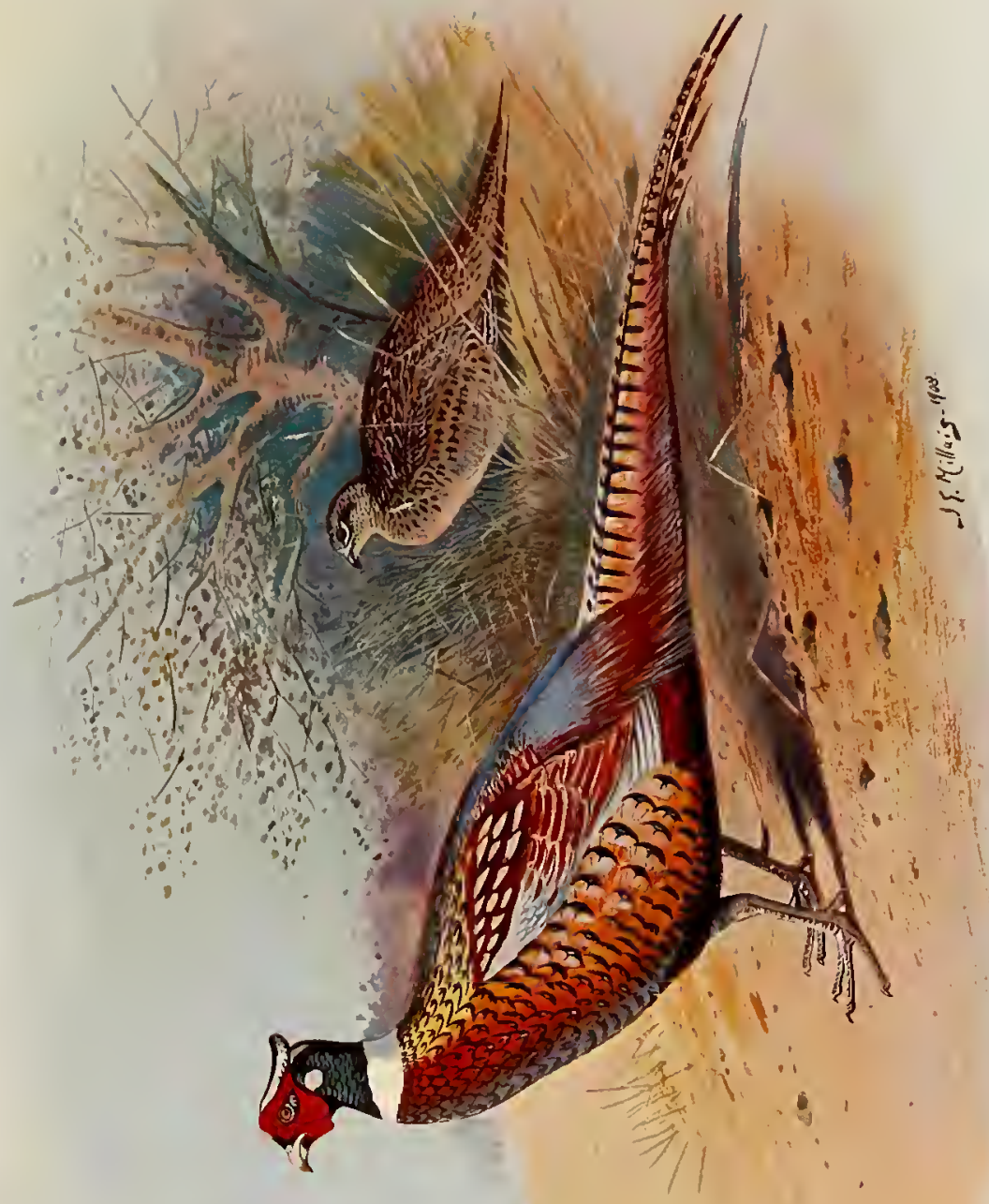

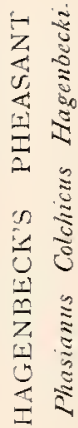





\title{
The Mongolian Pheasant
}

\author{
Sub-species of $P$. colchicus \\ HAGENBECK'S PHEASANT
}

Phasianus colchicus hagenbecki (Rothschild)

This beautiful sub-species, which may be called a glorified torquatus, was first described by the Hon. Walter Rothschild at the meeting of the British Ornithological Club, Nov. 20, 1901. His description is as follows:-

"This species is somewhat allied to $P$. torquatus, Gm., but differs in the following points : The scapulars are paler rufous buff, instead of dark bright chocolate-rufous or maroon-chocolate, as in $P$. torquatus. The flanks and breast are much paler, as are also the feathers of the hind-neck and mantle. The crown is clear chromium-green, instead of olive-green; the superciliary is twice as broad and snow-white, instead of greenish buffy white. The most striking difference, however, is in the feathers of the upper rump and lower back. In $P$. torquatus these have a sub-terminal, oval, transverse, and narrow bar of green, then one of buffy grey, then a more or less interrupted one of black, and, lastly, a black longitudinal centre, with the pale space on each side vermiculated with black. In $P$. hagenbecki these feathers have a creamy-white ground-colour, two green entire transverse sub-terminal bands, and then two smoky-black transverse bars across the middle portion of the feather. This gives the lower back and rump a much more mottled appearance in $P$. lagenbecki, which has also the lower and greater wing coverts clearer blue-grey. The front of the neck and the sides are oily green, instead of purplish blue washed with oily green. Wing, $26 \mathrm{c.m}$. (to $\frac{1}{4}$ inches); tail, $5 \mathrm{I}$ c.m. (2 $1 \frac{1}{8}$ inches). Hab., Kobdo Valley, NW. Mongolia."

Large numbers of these beautiful Pheasants were imported to the London market in April 1903. They are somewhat larger than torquatus, and would be a very desirable addition to our coverts if introduced in sufficient numbers.

Sub-species of $P$. colchicus

\section{THE MONGOLIAN PHEASANT}

\section{Phasianus colchicus mongolicus (Brandt)}

Adult Malc.-Throat, bronze-red shot with purple-a very broad white ring almost surrounds the neck, but does not meet in front; mantle, chest, and breast, orange-red, glossed with purple, carmine, and rich green; rump, maroon, glossed with green and purple; breast and flanks tipped with dark green; scapulars, orange-red, overshot with green; crown, greenish bronze, with a beautiful violet sheen. ${ }^{3}$ A noticeable feature

\footnotetext{
1 This sheen seems to increase with age.
} 


\section{IO2 The Natural History of British Game Birds}

in pure-bred males is the almost complete absence of the ear-tufts. In the breeding season the male has a very rounded head, and the small feathers above the ears are raised slightly. Total length, 36.5 in.; wing, 9.6 in.; tail, 22 in.; tarsus, 2.8 in.; weight from 4 to 5 lbs., but first crosses with $P$. colchicus and $P$. c. torquatus are often heavier. The soles of the feet are white; the colour extending to the top of the toes.

Adult Female.-The general plumage of the female resembles in some degree that of $P$. c. torquatus, except that it is much paler. A distinctive characteristic in the pure Mongolian is the form of the pattern on the rump feathers, which have two horizontal (and a suggestion of a third under the downy parts) bars of buff. These markings are narrower and more definitely pronounced than the buff marks on $P$. c. torquatus and $P$. colchicus; they are also of different shape. Female $P$. colchicus has a large dark area on the rump feathers and one blunt arrowshaped buff mark, and sometimes with the suggestion of a second above it in incomplete form. $P$. c. torquatus has two buff markings of very irregular shape, the lower being sharply arrow-headed with one side longer than the other, whilst the upper bar is more or less horizontal, broad, and uneven. The female Mongolian is also larger, paler, and has fewer dark markings on the chest and flanks. Another noticeable feature is the pale straw-coloured iris, which in the spring looks almost white; the legs and feet are also of lighter colour. Total length, 26 in. ; wing, 8.5 in.; tail, I2.3 in.; tarsus, 2.5 in.; weight, 3 to 4 lbs.

Crosses between all the different sub-species are now abundant in these islands and present every variety of plumage in the ratio of the degree of parentage.

Distribution.-Mr. O. Grant gives the range of this magnificent sub-species as "from the valley of the Syr-Darya, across the basin of Lake Balkash, as far east as Lake Saisan and the valley of the Black Irtish, and southwards to the valley of the Ili and Issik-Khul."

The first arrival of true Mongolian Pheasants in our islands was due to the initiative of Mr. Carl Hagenbeck, who has done so much to supply the wants of collectors of live birds and animals. In Igo I the Hon. Walter Rothschild and, I think, also Mr. Rowland Ward and Mr. C. E. Russell, had some of these birds, and at once appreciated their great beauty and usefulness as a new introduction to Great Britain. Coming, as they do, from the cold parts of China and Mongolia, they are very hardy and able to bear the extremes of both heat and cold. Those of us who have travelled much in countries much colder than our own in winter will have noticed that the summers in the sub-arctic zone usually come on with greater heat and more sun than fall to our islands, and with this additional warmth on well-drained soils comes an exceptional abundance of insect life. This is doubtless the case in the home of the Mongolian Pheasant, to whom an abundant supply of animal food is essential during the early life. A neglect of this, and the treatment of this sub-species on similar lines to $P$. colchicus and $P$. c. torquatus, has resulted in many failures to rear Mongolian Pheasants, and so at first this fine bird received the stigma of being delicate. This was particularly the case in Scotland, where warmth is always very late in coming and where the supply of insect food is often lacking at the time of hatching. In the 


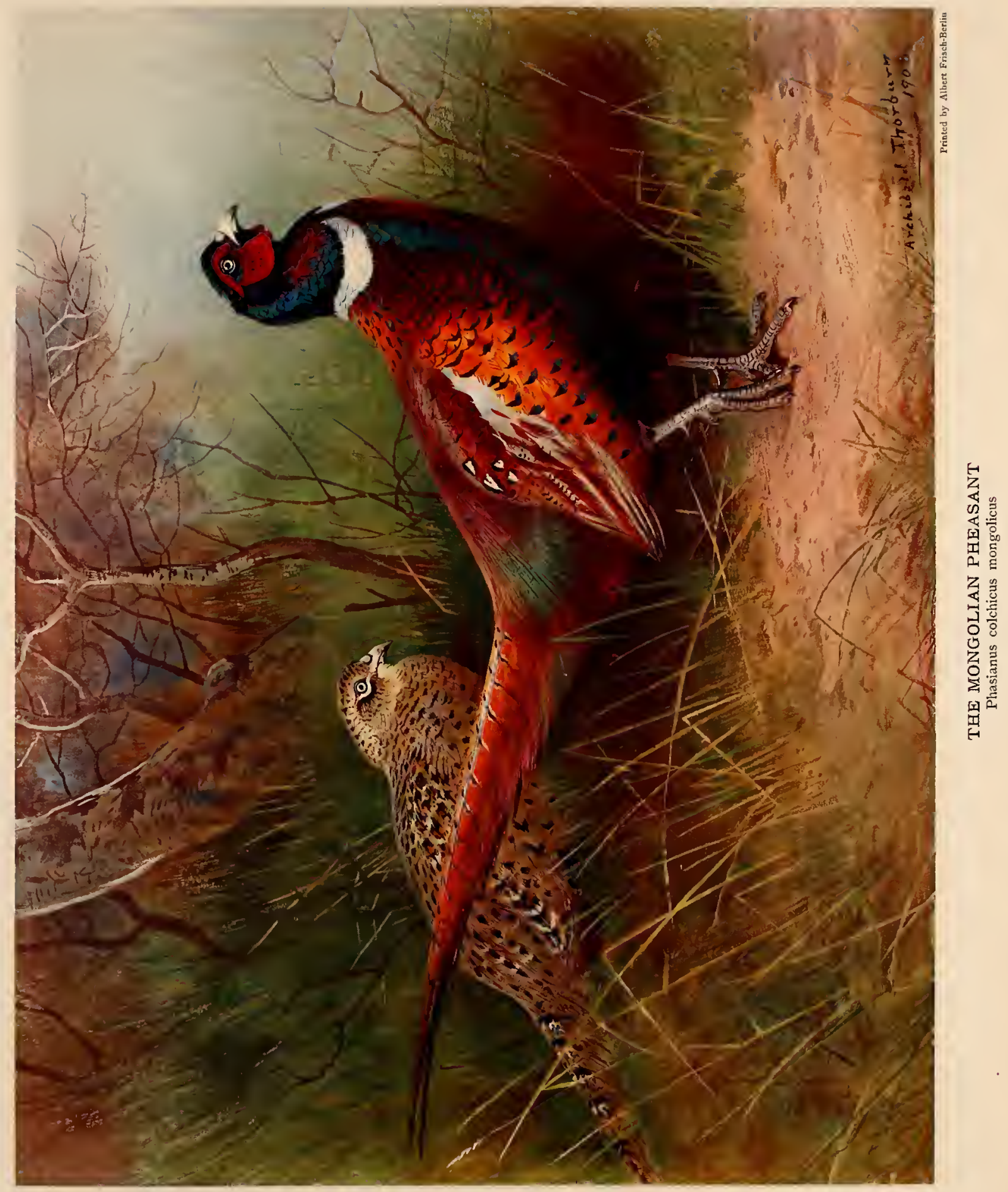





\section{The Mongolian Pheasant}

south of England breeders of pure Mongolian Pheasants, such as Mr. C. E. Russell, Mr. Hugh Wormald, and others, have been completely successful, and speak in high terms of them, both as table-birds and objects of beauty and sport. I need only quote one letter (Field, Jan. 16, 1909) written by "Baron" (Mr. Hicks), who has now given a fair trial for two years in Somerset both to pure and cross-bred birds. $\mathrm{He}$ says:--

"Mr. Salmon states that the Mongolian pheasant is not a good bird from the shooter's point of view, is lazy on the wing, and does not give a good sporting shot. On the other hand, Mr. C. E. Russell and another correspondent, P., assert that the Mongolian flies well, and the cross-bred bird better still.

"I have lately, through the kindness of a friend, had an opportunity of becoming personally acquainted with the sporting capabilities of both the pure Mongolian and the cross between the Mongolian and the Chinese birds, and can fully endorse all that Mr. C. E. Russell and P. have said about them.

"On the estate where I have recently been shooting, for some years the Chinese pheasant (P. torquatus) has bcen reared, and splendid sporting shots they have given. But for the last three years Mongolians have been introduced, and some of them have been crossed with the Chinese; the result is that the birds this year have shown better sport than ever. They rise freely to the beaters, and fly boldly, very fast and high ; in fact, if flushed on rising ground they fly almost too high to be reached. On one occasion when we were shooting, there was a very high wind, and the birds were fushed on a hillside over the guns placed in the valley; no one who saw them fly could possibly say that they were 'lazy on the wing and never gave a good sporting shot'; in fact, if anything, they were too active on the wing, and took such long flights that many of them went straight away out of that day's beat.

"As regards the hardiness of these birds, both pure and crossed, in a letter to the Field, June 20,1903 , the Hon. Walter Rothschild stated that for two or three years he had hatched and reared in the coverts at Tring a number of young birds both pure and half-bred, and those that were shot proved much supcrior in flavour and size to ordinary pheasants. The keeper on the estate where I have been shooting fully bears out this opinion, stating that the chicks are very hardy and easier to rear than those of the common pheasant. This is the more easy to understand when it is remembered that the Mongolian pheasant comes from the rough climate of Northern China and Southern Siberia, while the Chinese ring-necked bird comes from the north of China; the cross between the two, therefore, should be able to withstand any changes of climate found in this country."

There may be some difference of opinion as regards the pure-bred Mongolian for general use in our islands, but there is now no shadow of doubt that the first cross, $P$. c. torquatus and P. c. mongolicus, is the best bird in every way for British coverts. $^{1}$ It seems to fulfil every consideration that a Pheasant should possess.

In October 1907 an ex-gamekeeper, Mr. Thomas Pocock, wrote to the Field, saying that he considered pure and cross-bred Mongolians as undesirable birds, but his letter was immediately answered by a large number of professional and private Pheasant rearers, which confuted his remarks in every particular. Here, in Sussex, nearly all shooting men have met with great success with the cross-bred birds, and I have seen and killed many myself. In high woods, like those of Leonardslee, we see the birds at their best. They get on the wing very quickly, and at once rise to such an elevation that it requires good shooting to kill them cleanly. These cross-bred birds are of great

1 Many preservers show a great partiality for the Mongolian and Japanese cross. This hybrid is of great size and beauty, and has none of the delicacy of $P$. c. versicolor. 


\section{I04 The Natural History of British Game Birds}

size and weight, the males measuring 36 to 37 inches, and weighing as much as $5 \mathrm{lbs}$. and over. They do equally well in Scotland and Ireland.

Various correspondents in sporting papers have argued that if the pure and crossbred Mongolians have a fault, it is a tendency to stray more than other Pheasants. This argument will not, however, hold good, for the habit of straying is inherent in all Pheasants, and is induced or subdued according to local conditions. Want of food, position of coverts, rabbits destroying undergrowth, and abundant other reasons will cause Pheasants to become restless; and we know that early hatched birds begin to stray in September unless constantly "driven in" and supplied with suitable food. What may, therefore, be the experience of individuals does not necessarily mean an individual fault of the Mongolian Pheasant, but a lack of those amenities which are essential to its well-being. Pure-bred Mongolian Pheasants have recently been introduced to British Columbia and New Zealand, and there is little doubt that they will do very well in all these countries, which are more suitable to their requirements in every way than our islands, provided the districts in which they are turned down possess running streams. They told me in Vancouver that numbers of Pheasants (P. c. torquatus) died from thirst during one of the first years of their introduction. There is little running water in the neighbourhood, and a sharp frost occurring, all the surface water was frozen. In several cases the birds were found with tails frozen to the ground and unable to move. For some time the Americans confused this Pheasant with $P$. c c torquatus. The true sub-species was not introduced there until I 908.

Mr. O. Grant has said that he possessed no notes of importance with regard to its habits in its true home; but it is unlikely that it differs much from the other subspecies. There are, however, certain points with regard to the Mongolian Pheasant which we must notice as peculiar.

One of these is the appearance and attitude of Mongolian males in the springtime, both prior to and during the act of display. The cock carries his head sunk down and the body horizontal. Thus he "creeps" about during the breeding season. Moreover, the exhibition of the papillar patch round the eye is quite different from other Pheasants. When standing up he holds his head back and thrusts forward the front part of the neck, displaying the white ring to the utmost. The red wattle is not raised above the head as in $P$. c. torquatus, but is correspondingly larger below the angle of the mouth. The attitude of the male at this season is admirably shown in Mr. Thorburn's beautiful drawing, which is taken direct from life. The rudimentary ear-tufts, too, do not stand up as in other Pheasants, and the whole head has a much more rounded appearance. There is little doubt, too, that the actual courtship display is slightly different. Mr. Hugh Wormald, a keen observer of birds, writes to me (April 24, 1908):-

"I watched a pure Mongolian cock showing off to a hen this evening in a way I have not noticed one do previously. He lowered his head almost to the ground, fluffed out all his feathers, raised his tail, fully spread and twisted his rump, so that the tail faced the hen, although his body was sideways. The attitude was more like a Golden or Amherst cock, but the tail was more completely turned over. Then he moved it sharply up and down. He did this several times, crowing loudly between each display." 


\section{The Prince of Wales's Pheasant}

The spring crow of $P$. mongolicus is much shriller than in $P$. colchicus, in some individuals being almost a whistle.

They also have a note other than the spring call, different from all other Pheasantsthis is a sort of loud, sharp cluck; all through the winter one may hear the cocks uttering this call.

Sub-species of $P$. colchicus

\section{THE PRINCE OF WALES'S PHEASANT}

Phasianus colchicus principalis (Sclater).

Adult Male.-The head and neck very similar to $P$. colchicus, but ear-tufts nearly absent ; rump, bronze-red; there is no purple gloss on the rump, lower back, and upper tail-coverts. The chest and breast feathers, a rich golden-red, are tipped with purple and green. Like the Mongolian Pheasant, the wing coverts are white, and form a distinct contrast to the rest of the dark plumage. Total length, 35 in.; wing, 9.4 in.; tail, 21.5 in.; tarsus, 2.7 in.

As a rule, this sub-species is dark-necked, but pure-bred birds often exhibit slight traces of a white colour.

Adult Female.-Very similar to the female of $P$. c. chrysomelas, but with darker breast spots on the chest. It is a paler bird than $P$. colchicus, the general colour, exclusive of dark markings, being a pale sandy buff with rufous mantle.

Distribution.-The habitat of this Pheasant is North-western Afghanistan and North-eastern Persia. The first skins were exhibited by Dr. Sclater at the Zoological Society in April r885. They belonged to H.R.H. the Prince of Wales, and came from Bala Murghab, North Afghanistan, having been obtained by members of the Afghan Delimitation Commission. Mr. O. Grant gives ${ }^{1}$ the following interesting note on this sub-species, quoting Dr. J. E. T. Aitchison :-

"The specimens of this pheasant were all got on the banks of the Bala Murghab, where it occurs in considerable numbers in the tamarisk and grass jungle growing in the bed of the river. More than four hundred were killed on the march of thirty miles up this river. It not only wades through the water in trying to make from one point of vantage to another, but swims, and seems to be quite at home in these thickets, where there is always water to the depth of two or three feet. These swampy localities afford good shelter. In the mornings and evenings the pheasants leave it for the more open and dry country, where they pick up their food. I believe the same species is found on the Hari-rud river, but I have seen no specimens from that locality."

The Prince of Wales's Pheasant has been imported in considerable numbers to the Leadenhall Market. Game-rearers have been successful in introducing this fine bird to English coverts, where it has proved quite hardy and prolific. Colonel M. 


\section{06 The Natural History of British Game Birds}

Sunderland was the first to make a serious trial with the birds, and his remarks in Tegetmeier's Pheasants are of interest. He says (pp. 194-195):-

"In 190I I read in Tegetmeier's work on pheasants that the Prince of Wales's pheasant would be a welcome addition to the British coverts, and I therefore determined to introduce this beautiful bird into Europe. I first tried the importation of eggs, but they proved a dismal and costly failure. In the autumn of $1902 \mathrm{I}$ went to the East, and succeeded in securing several birds. No one could positively inform me whether this species of pheasant was polygamous or not, so I brought to England an equal number of cocks and hens. A useless precaution, for the cocks fought for the hens in the usual manner. The birds stood the long journey very well, and were turned down into large enclosures in Hampshire at the end of February 1903. They did not begin to lay till the end of April, but laid very freely, those in one pen averaging over thirty eggs a hen. Virtually all the eggs proved fertile. They hatched extremely well, and the strong chicks proved fully as easy to rear as those from the ordinary pheasant. They were fed on custard and oatmeal, etc., as recommended by Tegetmeier. They were brought up in fields of standing corn and buckwheat, surrounded by wire fences ten feet high, and the farm-yard hens employed as foster mothers were at large in these fields. The birds were pinioned when five days old. I wanted them to be able to fly a little, and severed the wing joint with scissors, so as to leave them with two flight feathers. This has proved a costly blunder, for with only these two flight feathers the birds could fly over the ten feet of wire with the greatest ease. It was quite a business to catch them in October, when I moved into Sussex, and indeed I left several birds in the woods of Conholt Park. Before turning them down in Sussex I removed the two flight feathers from each bird, but despite all precautions, some of the birds still fly over the wire. In shooting my woods several were seen, and two were shot, being mistaken for ordinary wild birds, so well did they fly. Each pen consists of several acres of wood, pasture, and arable land, which will be sown with corn and buckwheat. Only five hens and one (unrelated) cock run to the acre, therefore this breed of pheasant should remain free from all civilised diseases. I may mention that I have noticed that the birds are extremely fond of the flower of the common charlock."

\section{Mr. W. H. St. Quintin says: ${ }^{1}-$}

"I confess to a great partiality for this pheasant, which I have found prolific, particularly easy to rear, and no more prone to wander than any other species or cross that I have tried."

\section{Sub-species of $P$. colchicus}

\section{THE JAPANESE PHEASANT}

\section{Phasianus colchicus versicolor (Vieillon)}

Adult Male.-This is the smallest of the sub-species of $P$. colchicus, and its size is doubtless due to its long isolation on the Japanese islands. It is easily distinguished by its dark colour, and that the whole of the under parts are suffused with dark green, whilst the sides of the breast are a rich grass green. The mantle is

\footnotetext{
1 Field, January $23,1909$.
} 


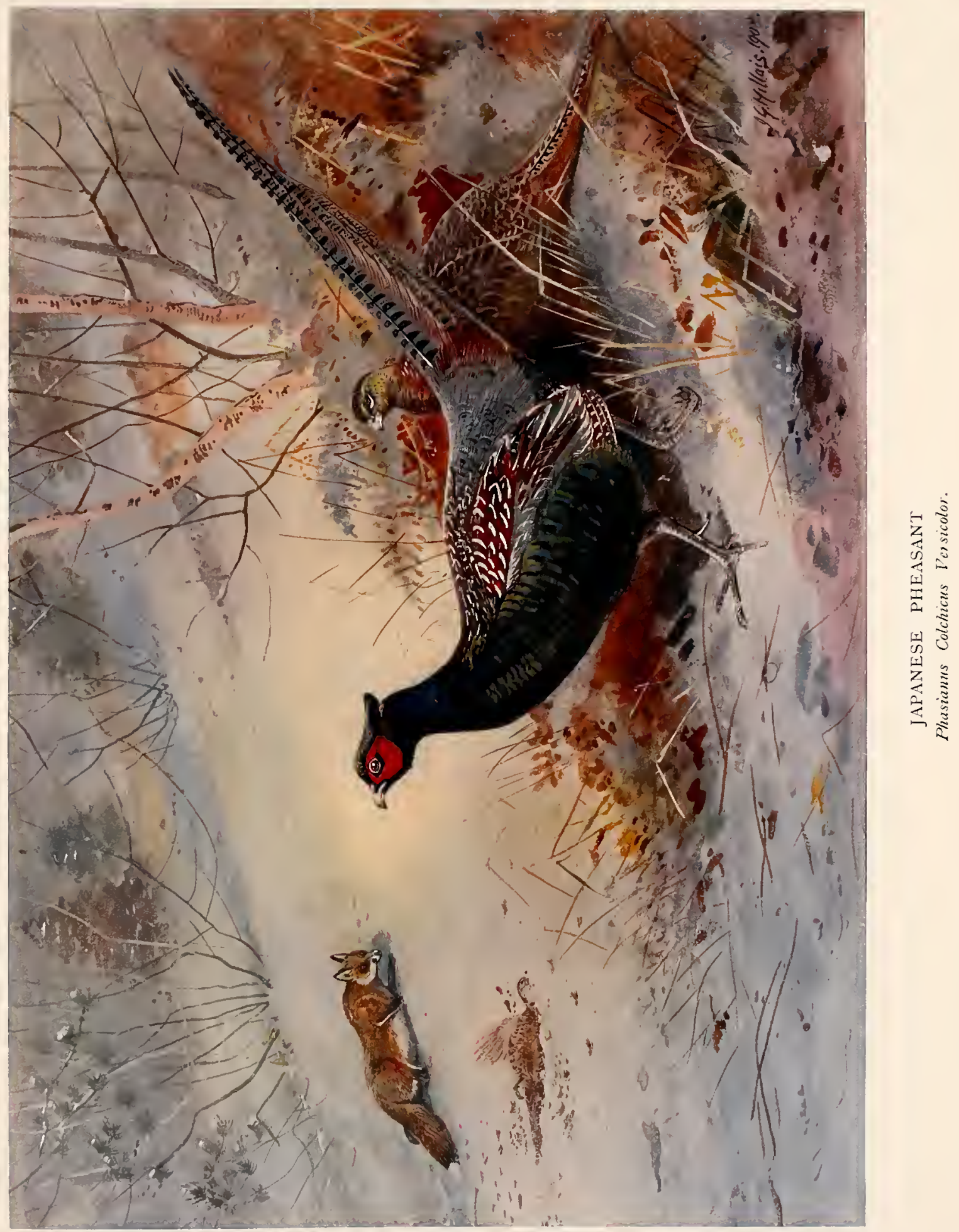



dark green shot with purple, the feathers being marked with concentric lines of pale buff. The rump is greenish slate colour. A slate tint also extends through the long feathers of the tail. The neck is bright blue; ear-tufts, green; forehead and crown, purplish green; back and scapulars, chestnut; primaries, brown, with whitish bars; tertiaries, brown, with grey flecks; irides, yellowish hazel; bill, bone colour. Total length, 29 in.; wing, 9.6 in.; tail, 17.5 in.; tarsus, 2.7 in.

Adult Female.-Darker than the Common Pheasant, with all the markings stronger; upper surface, blackish brown, edged with buff and chestnut; some suffusions of green on head and neek. Primaries and secondaries, brown, strongly barred with buff; tertiaries, dark brown, edged with buff on the inner webs, and with chestnut on the outer webs. Tail, dark brown, mottled with buff and black about the edges of the feathers. Throat, buff, and under surface of the body buff, with strong arrow-headed markings.

Distribution.-The Japanese Pheasant is only found in the islands of Japan (with the exception of Yezo). The first were brought to Europe in 1840, and a pair found their way into the celebrated collection of the Earl of Derby at Knowsley. Subsequently large numbers have been imported into this country, where it is used for crossing with other Pheasants.

There is a general consensus of opinion that pure Japanese Pheasants are not a success in our islands. They do not breed with the regularity of other Pheasants, and are not sufficiently hardy. In Scotland and the North of England the damp cold in spring is fatal to many. On the other hand, the first cross with the Mongolian, Chinese, or Common Pheasant invariably produce birds of the highest class in every respect, larger than either of the parents. I have seen a first cross Japanese and Chinese Pheasant that weighed $5_{\frac{3}{4}}$ lbs., killed in Norfolk in 1903.

The general habits of the Japanese Pheasant are very similar to those of the Common Pheasant. The spring crow is, however, quite distinct from the typical species, or its other allied forms. It is shriller, sharper, and more strained-seeming somewhat of an effort on the part of the bird. In the spring at roosting-time they keep calling repeatedly almost like a Peacock.

\section{REEVES'S PHEASANT}

\section{Phasianus reevesii, Gray}

Little need be said of this magnificent species of Pheasant, for it has never become a general favourite in our islands, owing to the fact that only limited areas are suitable to its habits and disposition. Moreover, with the exception of occasional crosses, the results of which are always infertile males of a bellicose nature, it does not breed with other species. It is, too, of such a warlike disposition in spring that all other Pheasants quickly give it a wide berth, and if the coverts are small it will soon drive away its more peaceful neighbours. Armed with spurs of unusual length and 


\section{I08 The Natural History of British Game Birds}

sharpness, the cock Reeves's Pheasant is a dangerous bird, even to its own species. I once saw a cock in the late Mr. Cholmondeley's aviaries at Condover kill three hens, which had been procured from China at great expense, in as many minutes. Two were struck dead instantaneously, a spur entering the back of the neck, whilst the third was cut open down the back in such a way that it had to be destroyed. At Woburn, in Bedfordshire, where the species does well in the large fir woods on sandy soil, it is a glorious sight to see them and other rare Pheasants sunning themselves in the woodland rides, and uttering their whistling scream of defiance. The males are great fighters in spring. I watched a combat there one May morning for a quarter of an hour, between two grand males with five foot tails. It was a splendid sight as both rose 6 or 8 feet as if by one impulse, and tried to strike downwards with beak and spur. The curious part of the affair was that neither seemed to touch his opponent, each avoiding the blow with all the arts of the skilled fencer.

The first specimen of this Pheasant in Europe was imported in 1831 by a Mr. Reeves, and a pair was seen in the Zoological Gardens in 1838 , where they created something like a sensation. Mr. Tegetmeier tells us that most of the living birds now in this country are owing to the exertions of the late Mr. John Stone and Mr. Walter Medhurst. At first there was much difficulty in obtaining the birds, as the main habitat, which we now know to be Chi-li and the mountains of North and Western China, was not known. At the present time large numbers of Reeves's Pheasants are kept in pens, and for general beauty no birds, except the Birds of Paradise, surpass them. The females are very uncertain layers in confinement, and do not seem to reach maturity, or their full egg-laying powers, until their third year. The male, too, does not grow to full size and beauty until the third or fourth season.

To enjoy the surpassing beauty of this species the naturalist must see Reeves's Pheasant in perfect freedom, and on ground similar to their natural habitat, and this spectacle can be witnessed properly only, as far as I know, at Guisachan in Ross-shire, formerly the seat of Lord Tweedmouth. To see a covey, for they often fly in a flock together, rise above the highest trees on a steep mountain side, and after uttering their peculiar cry, dash on at express speed, far greater than any other Pheasants, is a sight one can never forget. Until the year I8go I had seen and shot several Reeves's Pheasants, and under ordinary conditions of covert-shooting was content to consider the bird hardly a success from the shooter's point of view. During the autumn of that year, however, I received an invitation to the annual covert shoot at Guisachan, Lord Tweedmouth's beautiful seat, near Beauly, in Ross-shire, and it was there, amidst the wildest and shaggiest of Scotch scenery-in country which must to a great extent resemble the true home of the bird in question-that I had cause to alter my opinion.

In one high wood of old Scotch firs, on a steep and broken hillside above the waterfall, the sight of these birds coming along only just within gunshot, in company with Common Pheasants and Blackcocks, I sliall never forget. I say, "in company with," but, as a matter of fact, as soon as one of the long-tailed sky-rockets cleared the trees, he left the others far behind, and came forward at a pace which was little short of terrific. I doubt if any bird of the genus goes faster.

Now this is all that the sportsman wants. Here we have a bird of unrivalled 
beauty, great hardihood, and unequalled pace, which practically fulfils all the conditions which the modern shooter requires. The only other condition which is absolutely essential to make the bird a success from this point of view is its local environment. In this respect Guisachan is not singular, and I could name a hundred localities in Scotland, England, and Wales where Reeves's Pheasant would be certain to succeed.

The Guisachan birds were obtained by the late Lord Tweedmouth from Balmacaan, Lord Seafield's estate near Loch Ness, where I have also seen them shot. No artificial rearing was resorted to; the birds were breeding in a wild state, and shifting entirely for themselves, except for the maize which was put down for the ordinary Pheasants. At Balmacaan, where the birds were in low open woods, one may see Reeves's Pheasants killed in the way in which they should not be. Here these birds (as is the case when turned down on any ordinary English preserve) have formed most undesirable habits. It is with great difficulty they can be got to rise at all, and when this is effected they keep low, and afford no sport whatever. Now, at Guisachan all this is obviated by the rough nature of the ground. There is heavy bracken, fallen trees, mountain burns, and, above all, rough heather. These cause the birds to get up almost at once. The trees being high and dense, assist their elevation, and force them to a respectable height from the very start.

Reeves's Pheasant has the power to stop suddenly when travelling at its full speed, which may be estimated at nearly double that of an ordinary Pheasant; and this is performed by an extraordinary movement when the bird makes up its mind to alight on some high tree that has taken its fancy. This bird may be said to be furnished with a "Westinghouse brake" in the shape of its tail, otherwise the feat would be impossible. By a sudden and complete turn of the body, both the expanded wings and tail are presented as a resistance to the air, and the position of the bird is reversed. This acts as an immediate buffer and brake, and by this means the bird is enabled to drop head downwards into a tree within the short space of eight or ten yards.

Lord Ravensworth, in writing of the beauty of these Inverness-shire birds, refers to their difficulty of approach, saying that they take to their legs long before other Pheasants are conscious of danger. This is quite true, for they seem as clever as deer or fox to notice the movements of men in their vicinity. One remark of Lord Ravensworth requires some comment. He says: "Any attempt to walk up to them in brush covert is utterly hopeless, for they are exceedingly vigilant and go straight off like a dart, not more than six feet from the ground." Most of the old cocks which at first were found hidden in the high heather and juniper adjoining the coverts rose far out of shot, and skimmed away to shelter, as Lord Ravensworth describes, but I noticed that many one or two year old cocks and most of the hens sat very close, and rose with a disconcerting scream at our feet, and at such times they obtained an elevation similar to other Pheasants. These birds were of course not shot, but allowed to pass into the high woods.

Female Reeves's Pheasants cry almost as loudly as the males. Both sexes have another curious piping call, more like that of a little finch than of such a noble species. It is quite useless to turn out Reeves's Pheasant in flat wooded countries, for they will 


\section{10 The Natural History of British Game Birds}

wander across a county as easily as another Pheasant will stray over a field. A friend of mine in North Sussex purchased a cock Reeves's Pheasant from a breeder of birds, who lives near Brighton. In a few weeks he got tired of his purchase, and gave the bird its liberty. It stayed about the farm a few days, and was noticed to be missing one evening. The following afternoon it was observed sitting on the top of the Pheasant pens where it had been reared, thirty miles distant.

Hybrids between this species and the Common Pheasant are not rare. They are invariably sterile. The late Lord Lilford described this cross as "a most splendid bird." Personally, I think that the ugly pied head destroys the general beauty. The gloss on these hybrids is certainly remarkable, superior to either of the parents, but in actual form and coloration the result is disappointing. Reeves's Pheasant has also been known to cross with the Cheer Pheasant $(P$. wallichi), the Golden Pheasant, and Soemmering's Pheasant. 


\title{
Genus Perdix
}

\section{THE COMMON PARTRIDGE}

\author{
Perdix perdix (Linnæus) \\ LOCAL Names.-Petrisen (Partridge), coriar (Little hen), clugiar (Click hen) (Welsh); cearc Thomain \\ (Knoll hen), chearc cruthach (Horseshoe hen) (Gaelic); Perdrix grise (Frenck); Rebhuhn (German).
}

Adult Male.-General colour, except the lower parts, brown buff, more or less suffused with grey, the feathers cross-marked with narrow wavy lines of black; lesser and median wing coverts and scapulars blotched on the inner web with chestnut; shaft stripes, buff; breast, grey finely crossed with black; on the upper part of the white under parts is a large dark chestnut patch $^{1}$ in the form of a horseshoe. The flank feathers are broadly barred with chestnut. Crown of head, brown; front of head, throat, and upper neck, chestnut. Total length, I2.6 in.; wing, 6.2 in.; tail, 3.5 in.; tarsus, 1.7 in. Legs and feet, bluish grey in adults, and yellowish brown in immatures. Specimens of moorland Partridges from the bog areas of Scotland, Wales, and Ireland are very dark, often with no white in the under parts except round the breast patch. They are small, weighing about 12 to I5 oz. The lightest in colour and largest specimens come from the sandy soils of Norfolk, Hants, Suffolk, Lincolnshire, and Cambridgeshire, where high cultivation is maintained. Weight, 15 oz. (hill Partridge) to $18 \mathrm{oz}$.

Adult Female. - Mr. Ogilvie Grant was the first to point out a characteristic difference between the sexes. He has shown that in the female the ground colour of "the lesser and median wing coverts and scapulars are mostly black, with wideset buff cross-bars, in addition to the longitudinally buff shaft stripe down to the middle of each feather." Another almost invariable difference is that in the female the chestnut breast feather is small or completely absent. Yet a third important point of difference that $\mathrm{Mr}$. Grant does not mention, and one which rarely alters in the two sexes, is the difference of the head and neck markings. The crown of the male is a uniform chestnut-brown, with very small shaft stripes of the same colour but paler, whilst in the female the shaft stripes are pale buff and much larger; the feathers, too, on the upper ends exhibit more brown-black than the males. The nape of the males is grey ground, with fine irregular bars of black and suffused with sandy-brown, which increases and is further barred with deep chestnut over the scapulars, and there are no half shaft stripes. In the females we rarely see any chestnut in the nape, the

I In certain districts the males sometimes, and females often, exhibit no sign of the horseshoe, or a very small one, whilst in others there is a tendency towards a black horseshoe. The most beautiful Partridges I have ever seen were some I shot at Ballathie in Perthshire (on sandy soil). The horseshoes of both males and females were nearly black.

Field, Nov. 21, $189 \mathrm{I}$, and April 9, $189^{2}$. 


\section{2 The Natural History of British Game Birds}

black markings are broad and strongly marked, and fine buff and half stripes extend up to the crown and often as far as the cheeks. The foregoing are well-marked differences which seldom vary. Females weigh a few ounces less than the males.

The immatures somewhat resemble the adults, although all their markings are finer and less pronounced in colour. Both young males and females have well-marked horseshoe marks on the breasts, and their legs and feet are yellowish. Mr. Grant has noticed that the first primary flight-feathers of young birds are pointed at the extremity instead of being rounded, as in the adults.

Distribution.-The Common Partridge is found in Spain, Portugal, Belgium, France, Germany, Bulgaria, Turkey, Austria and Hungary, Northern Italy, the foothills of the Caucasus, Asia Minor, Denmark, South Norway ${ }^{1}$ and Siveden (in small numbers), the British Islands, Holland, the eastern side of the Adriatic, the mountainous districts of Persia, South-eastern Siberia, and the lands below the Altai Mountains, where it changes slightly to a larger and greyer race." In Eastern Asia an allied species with deep black horseshoe marks takes the place of the western bird. It may be taken as a truism that an estate cannot have a fine stock of Partridges unless the soil is light, the farming is good, and nesting-places secure. In all counties of England and Scotland where Partridges are abundant such conditions prevail. The best counties in England for Partridges are Norfolk, Suffolk, Essex, Cambridgeshire, Bedfordshire, Hants, Huntingdon, and Nottingham, with individual estates in Shropshire, Yorkshire, Sussex, East Kent, and Wilts. In Scotland the best counties are Perth, Aberdeen, East Lothian, and Forfar, whilst a few places in Fife, Wigtown, and Morayshire produce large numbers of birds.

The Partridge has been introduced more than once to the Outer Hebrides, but without success. In the Inner Hebrides it is common in Colonsay, and there are a few on Tiree, Rum, Eigg, Gigha, and Jura, the result of recent introduction; but it is doubtful if they will thrive unless frequently reinforced by new birds. They have been introduced to Lewis and North Uist, but without success. Frequent introductions to Orkney have failed, though a few are still said to exist in Rousay and Shapinsay, but will doubtless soon die out. In Ireland the Partridge is resident and breeds in every county, but it is a vanishing species, owing to wholesale poaching and to grain lands going out of cultivation; for they seem to disappear when large areas are used solely as pasture. Ireland, too, is less favourable to Partridges than England, owing to its wetness. In Louth they have been almost exterminated by rooks robbing the nests. In Wales the species is common in all counties, and ascends the hills to the elevation of I200 feet. It is abundant in Anglesey and all suitable parts of North Wales.

Habits.-There is no British bird that is so essentially English as the little

\footnotetext{
1 According to Professor Collett, Partridges first appeared in Southern Norway, coming from Sweden in i744. A second migration occurred in 1811 , which was far-reaching, the birds spreading over most of the cultivated areas in the furtile valleys, where they are still found in small numbers. In 1860 a covey was seen in the Fillef jald, at an altitude of 3200 feet. Its introduction into Sweden, where it occurs as far north as $60^{\circ}$ north latitude, was supposed to have taken place in the sixteenth century. Partridges have recently appeared in Finland.

2 East of the Altai is found the handsome Daurian Partridge $(P$, barbata), a species that would doubtless do well in our islands.
} 


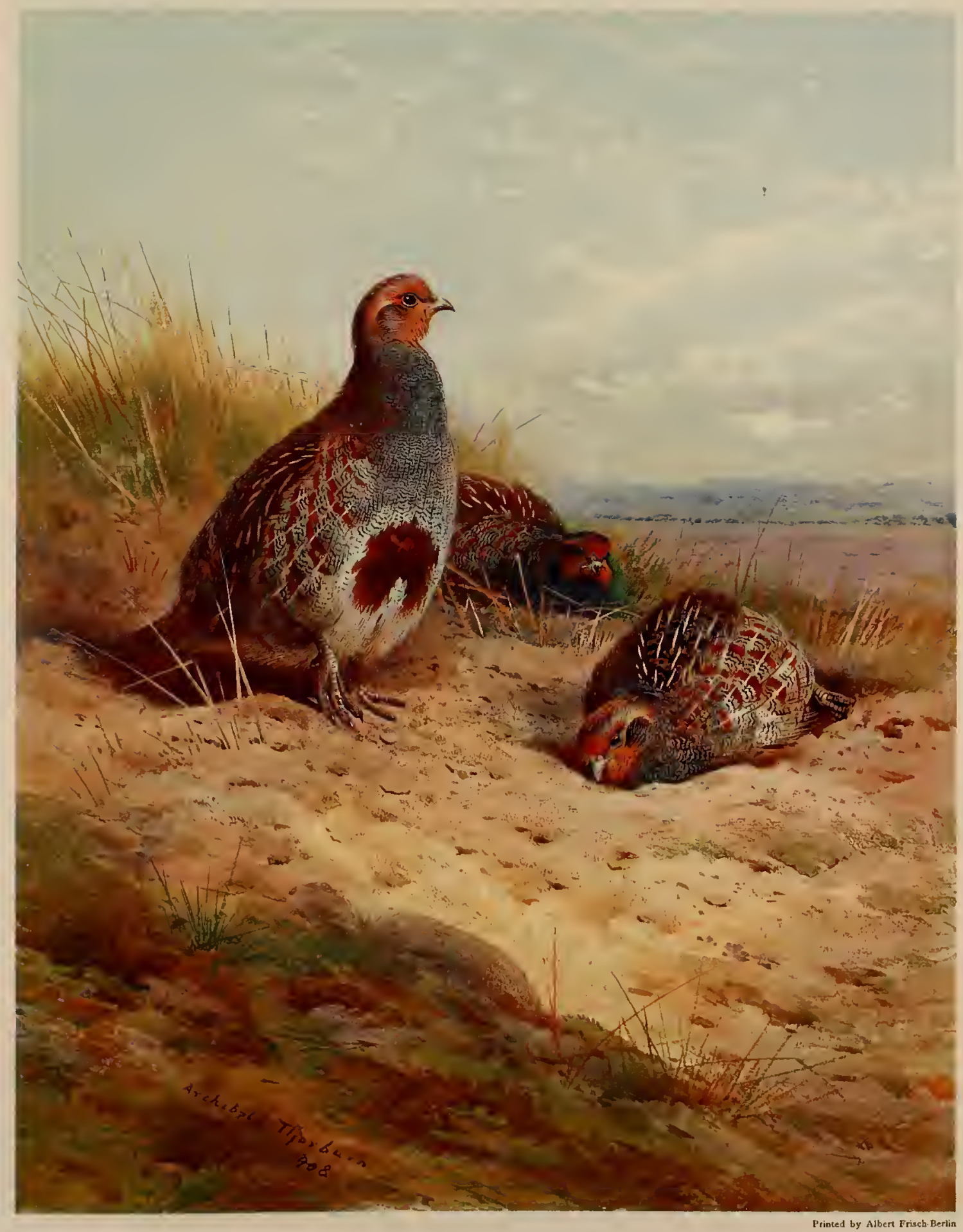

THE COMMON PARTRIDGE

Perdix cinerea 



\section{The Common Partridge}

brown Partridge. Wherever and at whatever season we see his scurrying form and hear his cheery call he is always a certain attraction to the landscape, even more so than the gaudy pheasant, for he is our very own, and is cherished for his beauty and innocence, even if his claims as a bird of the chase were insignificant. Our fields and hedgerows would be bare indeed without his presence, for no other bird quite fills the place of the Common Partridge. It is lovable because it is always with us. As I sit in my study writing this, I can hear the Partridge cocks that have just paired shouting gentle defiance to other males in the fields beyond, and their merry voices blend with all the charming calls of birds proclaiming the English spring. I do not shoot in one field in front of my house just because I like to see and hear the Partridges, and they are always there to gladden the snowy days of winter, the lush greens of spring, or the golden days of autumn. A comparison of birds is just as odious as any other comparison. The Partridge is not less popular in England than the grouse in Scotland, and each is respected by peer and peasant alike, apart from the fact that they give work to thousands of men.

By nature the Partridge may be described as a fairly hardy species. Our climate is so variable that it is unusual to experience more than a few weeks of frost and snow, and unless much protracted the severities of winter are felt but little by the birds. In certain localities, such as the north-east of Scotland, the struggle for existence is serious; but in this respect Partridges seem to suffer less than grouse, although they are not so hardy a bird. In fact, excessive drought or humidity in summer has more to do with the welfare of Partridges than winter cold, as it is the young which are the most affected in their earlier stages. ${ }^{1}$ All attempts to introduce Partridges into new areas where there is some cultivation are not successful, but under reasonable conditions they can be induced to flourish in almost any place in our islands, provided a few broad rules for their maintenance are observed. As is the case with all game, preliminary attempts are nearly always failures; for it is necessary to follow up by a constant supply of fresh birds, spread over, say, two years, before we can say for certain whether the introduction will be a failure or not. This is the view of nearly every game preserver who has had practical experience.

Partridges are on the whole adaptable birds and will soon acclimatise themselves to new conditions, provided there is some sort of food that is agreeable to them. I have, however, known coveys of Partridges that remained on moorlands, and even about bogs in Scotland, which they never left, even to fly to highly cultivated fields of light soil only one mile distant. They are, it is true, a deteriorated race, but seem quite content with a life that might be only fitted for a snipe. At Murthly, on the edge of the "Big Bog," there were always two or three coveys amongst the rushes about the swamp, in the midst of a moor of 500 acres, and these Partridges were never seen to stray at any season. A diet of insects, grass, fruits, heather, and rush seeds seemed all sufficient.

The main cause of the decrease of Partridges in districts that are suitable to their habits, and where they have once been numerous, is the destruction of suitable nesting-

1 Nevertheless, numbers of adult Partridges die in August and September from inflammation of the lungs, doubtless due to the contact of wet ground, when their breasts are almost denuded of feathers. 


\section{4 The Natural History of British Game Birds}

places. Here in West Sussex where I live we have a case in point. Twenty-five years ago gunners used to kill seventy and eighty brace a day; now a bag of forty brace for the season is about the limit. Within the last ten years all the nice wild spots of furze common have been reclaimed; all the old-fashioned double hedgerows have fallen before the bill-hook; and the few Partridges that are left nest by the roadsides, where predatory dogs and boys give them no peace, or in the clover fields, where the cutting machine destroys the nests in June. Two years ago I found ten nests in one clover field thus destroyed.

A bird so local in its movements must have nesting-places secure from disturbance, and without these no shooting tenant can hope to have a stock of Partridges. Most keepers and tenants utterly neglect this essential point, and waste their time and money in introducing Hungarians or in artificial rearing-both very good ways of increasing a stock, but in no wise equal to natural conditions.

A writer in the Field (March 28, 1908) thus describes a suitable Partridge ground :-

"The partridge is essentially the poor man's game bird, being hardy, prolific, and rcquiring less attention throughout the year than the pheasant. If the ground is not shot over too much it strays little, provided the soil is suitable, and affords sufficient food, and shelter in bad weather. Before taking a partridgc beat the prospective tenant should first satisfy himself as to the suitability of the soil. Cold clay is bad, both in very wet weather and also in dry, as in the former case water lodges badly, and is apt to drown young chicks, and in the latter the clay cracks, leaving large fissures, into which the young birds fall and are unable to extricate themselves. There are one or two shootings which I know well, and which never carry a large head of birds. If a heavy stock is left to breed, many of the birds simply disappear and spread over the neighbouring manors, as the ground they are on will not support more than a certain quantity of game. Further, I do not think that the same amount of insect life hatches out on heavy as on light land. One has only to lie down on a bit of old turf growing on light soil during spring or early summer to satisfy oneself as to the abundance of spiders, grasshoppers, beetles, and other insects which form part of the food supply of game birds. Many farmers nowadays cut their hedges down so low that not only are they of no use as shelter, but frequently the hedgcs themselves die off and have to be replanted, being unable to stand such drastic treatment. Hedges take root and grow more slowly on clay land than where the soil is light, and it is realised in the latter case that a fairly tall hedge acts as a screen, and prevents, to a certain extent, the light soil from being blown away. Of course, I am speaking of arable land only, for where stock are grazed hedges must be allowed to grow in order to afford them sufficient shclter.

"Personally, I believe that the best land for partridges consists in a good variety of soils. Let thc greater portion of the beat be light, loamy soil, with stretches here and there of something stronger and heavier. There must be a certain amount of grass, too, and all the better if it does not flood. I likc also an occasional bit of waste land or heather, which is generally quiet and where birds can rest in peace when work is going on in practically every field of arable land on the shooting.

"Needless to say, the shooting should have several warm, sunny slopes, be fairly well drained, and, most important of all, be well supplied with water. Shallow dykes running right through or across the manor are excellent. Partridges love to nest on a bank with a dyke below it, possibly because their instinct tells them that water is essential to them during incubation. Always provided that there is an abundant dew, partridges can do without water; but once a real drought appears and no dew falls, then it is that the shootings which have a good and sufficient watcr supply show their superiority. On beats where water is scarce it is essential during dry seasons to provide birds with a liberal supply. If this is not done they die 


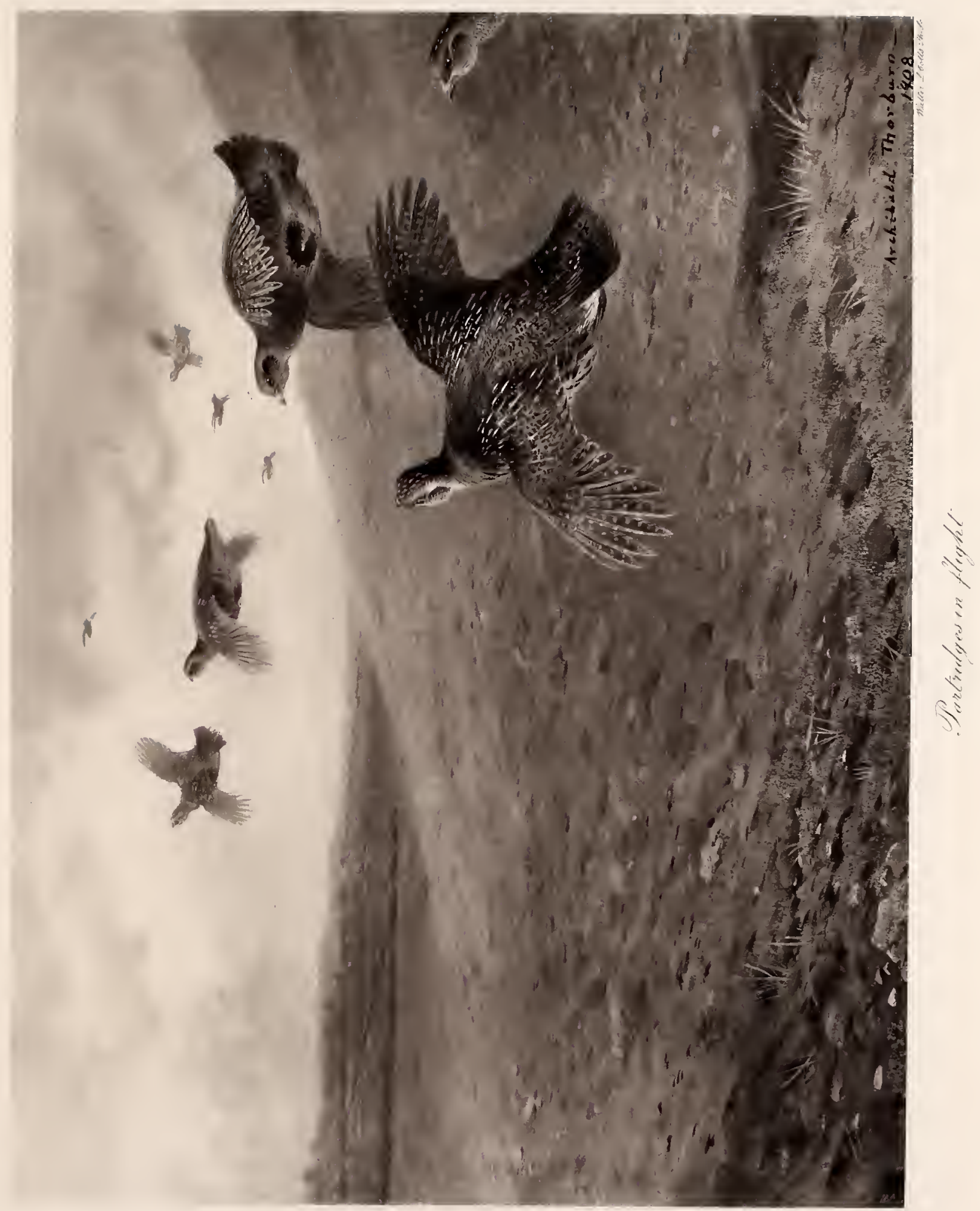





\section{The Common Partridge}

in large numbers, the survivors migrating to the nearest grass land which has water in its proximity. It will almost invariably be found that in a very dry season birds bred on grass land do exceptionally well."

No game bird is so unmigratory in its habits as the English Partridge. Occasionally we hear of coveys dropping into the streets of Eastbourne and Brighton, but these are in all probability local coveys, which by repeated disturbance have lost both their heads and their way at the same time, and have not come from afar. They have not, so far as I am aware, been taken at sea on board vessels, nor have they been seen to fly over wide stretches of water. On the Continent, however, where they are exposed, as willow and black grouse are, to greater degrees of heat and cold with its proportionate increase or decrease of the food supply, Partridges are semi-migratory and move with a certain degree of freedom, except when stopped by great rivers and mountain ranges. That the Partridge will cross a mile or two of water is instanced by the late Rev. H. A. Macpherson, who says ${ }^{1}$ that they regularly traverse the Solway Firth, from the slopes of the Dumfriesshire hills to the well-cultivated areas of the Cumbrian plain. This, however, we must take as an exception.

I can, however, cite another instance. Every year a few broods of hill Partridges are reared up in the Perthshire mountains about Dalwhinnie. These invariably return to the lower straths at the commencement of winter.

By nature the Partridge is monogamous and gregarious. Each pair of birds live with their progeny in the open fields until the nesting season, when fighting and a break-up of the covey takes place. They feed in the early morning and late hours of the afternoon on the grass and clover fields, and even during the day, when they rest under hedgerows or in open marsh or grass fields, they pick about leisurely at the grass tufts, or sun and bask amongst the whins or sandy banks, spending much time in dusting and arranging their plumage. At night they "Jug" together closely in some grassy meadow, the heads all inclining inwards to some central point. Partridges are most at home on land that is light, rich, and highly farmed, but a model farm is scarcely to their liking, for there should be some rough unkempt fields in the vicinity, where Nature has it all her own way. These birds have a marked partiality for rough moorlands bordering on tillage, and in such places the best of shooting can be obtained, for coveys will scatter and lie well in the borderlands where they were bred. These moor Partridges are wilder, smaller, and better for the table than "field" birds, and obtain most of their food in their natural home. In Surrey, Staffordshire, Yorkshire, and Northumberland there are many of these moor Partridges, and in Ireland and in Scotland are numbers which never go to fields at all at any season. The moorland Partridges are hardy birds, and seem to be quite as capable of withstanding the winter blasts as the grouse, provided there is an abundance of grass, fruit, and rush seeds to satisfy their wants. Many species of birds which have been introduced into cold climates and are considered delicate are not so in reality, but are capable of bearing very low temperature, provided the right sort of food can be found. ${ }^{2}$ No matter how

1 The Parlridge.

2 A good instance of this occurred in 1908 when a rifle bird, one of the birds of Paradise, escaped from confinement in Sussex during the autumn. On recapture a month later it was found to be in better condition than when it escaped. 


\section{6 The Natural History of British Game Birds}

heavy the snow, there are always spaces on the moor edge where the snow is not deep or has been swept clear. Such spots are known to all grouse and Partridges in the vicinity, and on them they burrow and scrape until something palatable is found.

In the fields Partridges fly from their roosting-places soon after daybreak, and occupy their feeding-ground until about to A.M. Here they find a great variety of foods. In spring, summer, and autumn they are very insectivorous, and devour quantities of flies, ants and their pupæ, beetles, crane-flies, \&c. They are also especially fond of the aphides that cluster on the under side of turnip leaves. In spring they are fond of the tender shoots of heather, bramble, and blueberry, but their principal food at this and all seasons is the young shoots and leaves of grass and clover. Partridges eat enormous quantities of young grass, and those kept in confinement seem never so happy as when tearing a tuft to pieces, pecking off every point, and even rending the roots asunder and dusting in the drying earth. What John Evelyn calls "those incomparable sallads of young herbs" found in the crop of the Partridge, may consist of dozens of the succulent shoots of wild plants and the seeds of weeds noxious to the farmer and too numerous to mention.

When the sun gets hot, Partridges run or fly to some.well-known knoll or sandy hill and indulge in a dust bath, afterwards preening their feathers and resting, and enjoying the warmth in various graceful attitudes. These situations are generally retired, but these birds are adaptive, and if no better place is at hand the dust of the roadside will serve the purpose.

The Partridge is one of the first of British birds to feel the influence of early spring on the amatory passions-often long before the departure of frost and snow. Those pellucid days of late January, even when accompanied by slight frosts, contain a certain element of promise-it is only a promise of better conditions, but is sufficient to set fiery natures aglow and awake the instinct of matrimony, until now subdued by physical hardship, into a living force. A slight lift in the atmospheric conditions, a few gleams of sun, and the cock Partridges are calling, jerking their tails and standing about in defiant attitudes. At first they drive each other away, and select wives in a half-hearted fashion, doubtless feeling all the time that the mating season is not yet, because with the fall of temperature towards evening they are again calling each other to roost in one covey, as in the worst days of winter. And so advance and retreat towards the actual pairing season fluctuates according to the weather, season, and latitude throughout the days of January and February. There is no definite date for love-making to commence, but in normal springs Partridges are in full pairing about the Ioth to the 2oth of February in the South of England, although individual pairs may be seen together long before these dates. During a warm day in February we may watch the break-up of the covey and their manouvres for the whole day. The male stands up by the side of some female which squats in the demure acquiescence of one that likes to be possessed and utters his pleasant "kerr-wip," now much drawn out and somewhat subdued in tune. One or two unattached and restless bachelors are seen running and calling in other parts of the field. Soon one of these approaches-sometimes very slowly, by means of short runs, and sometimes with flight and a headlong dash-one of the paired males. Then a fight ensues, in which each male flutters up for a yard or two, 


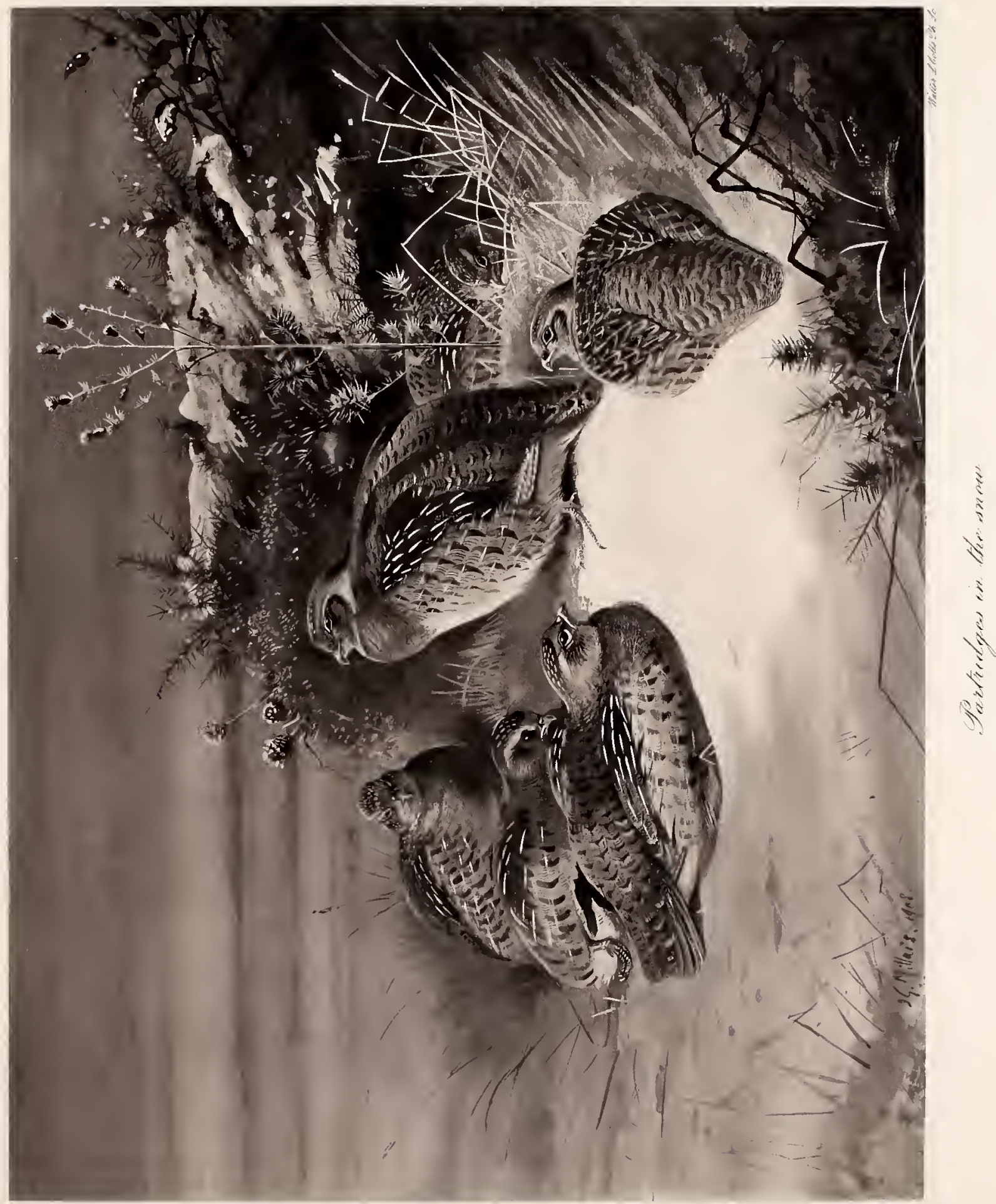





\section{The Common Partridge}

endeavouring to strike the other with bill, feet, and wings. The top of the head is usually the object aimed at, and here alone can any injury be inflicted. The combats sometimes last for several minutes, when one or other gives way and retreats at full speed, pursued for a short distance by the victor, who then retires to the side of the female and recommences his call. Sometimes the males simply chase one another, and then stand, fence and box, as it were, with their bills. As is the case generally with all game birds, the female runs round and round the combatants in a great state of excitement, uttering a peevish note and flapping the wings, whilst sharply raising and depressing the body. The tournament ground may be frequented for some days when spring follows a normal course with increasing warmth. The individual pairs then gradually move away to select a certain "beat" where a suitable nesting site may be found, but if severe conditions again prevail the pairs may be drawn together again and coveys formed for a few days as late as early March, when fresh battles and tournamenting recommence. Once paired for good in March, Partridges are inseparable, and not subject to chronic disturbance by storms and wandering cocks as grouse are. Sometimes a preponderance of males may occur, but as a rule the sexes seem equally divided.

There is little doubt that the hens often fight for their mates as fiercely as the males, and both sexes of a pair have frequently been seen to attack and drive off a rival pair that have invaded certain spots chosen by the first comers. J. B. Waldy, writing from Cranleigh to the Field, July 24, 1909, has described the warfare of female rivals:-

"A notice in your issue of the Ioth inst. of Mr. Dewar's article in the Avicultural Magazine, in which he describes how the hen paradise flycatchers 'mock Darwin by sometimes fighting over a cock,' prompts me to record a similar action in the case of English partridges. A friend of mine who feeds the wild birds had as regular visitors last year a pair of partridges, the hen being easily recognised, as she had lost one foot. At the usual time they brought off a brood, but were not very lucky with the young ones, which were gradually reduced in number until only one was left. This with the old pair regularly visited the garden, where they were fed throughout the winter until the pairing time came, when the young one, which proved to be a hen, fought a series of battles with her mother, eventually drove her away and mated with the old cock, to the great disgust of their entertainer, who took a special interest in the old hen as being a marked bird. It all came right in the end, however, for after a week or two, when she had been given up as lost, the old hen came back with a new mate, with whose help she vanquished and drove away the other pair from the garden and field, where she has remained undisturbed ever since."

The female begins to seek out her nesting-place soon after the pairing season in March, and chooses spots that are retired and rough with vegetation. They are very fond of heather, coarse grass, fern banks, rushes, isolated thickets of grass and brambles or short gorse, but seldom go far from the open spaces they frequent. Where rough ground is not to be found they nest in wide hedgerows, open clover and hay fields, and are fond of the smaller thickets of blackthorn so common about the roadsides and country paths in Surrey and Sussex. It is only too obvious that the destruction of all wild places on an estate means the death of Partridges; for if they cannot get such retreats in which to nest, as well as protection during heavy rains, they are forced into the open fields, where the mowing-machine is a car of Juggernaut. Nowadays the 


\section{8 The Natural History of British Game Birds}

disposition of modern farming seems to tend towards mathematical ugliness and to strip Nature of all her beauty. Bare billiard-table fields and hedgerows cropped like convicts seem to have taken the place of varied open lands, rugged "gills," and broad roseembowered fences. The beauty of England is disappearing, and with it go all the charming wild things that tend to make the country life the only life worth living. It is sad to see the best of the Partridge grounds in Kent, Surrey, Sussex, and the Midlands ruined, for the sake of the few pounds saved for additional agriculture. Proper conditions can only exist when the land is shot over by the owner of the soil; for he can attend to the wants of his birds, and will create or leave some of the waste places of Nature that are essential to the welfare of the little brown bird.

The nest is usually a cavity in the soil, scraped by the female to no great depth, and lined with a few leaves and stems of withered grass. In this she lays from ten to twenty olive-coloured eggs. ${ }^{1}$ Incubation commences about May 25 th and lasts for twenty-one days. In Sussex we generally see the first brood about June 15th, whilst in the eastern counties the time of hatching is about a week later. Like the pheasant, the Partridge will often make her nest close to a roadside where men and dogs are constantly passing, and often pays the penalty of her childlike confidence at the hands of marauding boys. Most of such nests would be destroyed were it not for the fact that she sits very close and gives forth no scent whilst she is on the nest. This absence of scent of "sitting" gallinaceous birds is very remarkable, and has not been properly explained; for it seems that the bird has some power to prevent the natural odour from escaping in moments of danger. We have all had the experience of "winging" a grouse or Partridge which a well-trained dog has immediately followed with zest and then as suddenly been at fault, although escape on the part of the bird seemed impossible. The wounded one has not been found, however, owing to the fact that it has crept into some cranny or passed right away without leaving further scent. I think it is quite possible that when the injured or sitting bird has apprehended the danger, it holds the feathers very tightly and can prevent the smell of the skin and body from escaping. I call to memory an instance of the trustfulness or stupidity or cunning, whichever the reader may regard it, of Partridges nesting in dangerous places, and of their power of retaining their scent whilst sitting. About five years ago I was walking with my wife and a favourite spaniel possessing an exceptional nose, in the suburbs of Horsham. The spot was at the angle of three roads where houses end and the railway to London passes by. It is a favourite walk of the people of the town, and I should say that not less than fifty dogs daily pass with their owners and hunt the hedgerow. At the top of the hedge I noticed a chaffinch's nest, and saw the bird fly out. Wondering how such a nest had escaped the vigilant eyes of the Grammar School boys only a few hundred yards away, I climbed the bank to see if the eggs had been taken, and was in the act of putting my hand in the nest when my foot rested on the back of a Partridge that was sitting underneath. She escaped with much flurry, and I was engaged in placing some leaves upon the nest, so that it could not be seen from the road, when my dog almost grabbed another Partridge, this time a red-legged one, that had also been seated on its nest not three yards away. Curious to relate, the

\footnotetext{
1 Abnormal eggs are often white, and occasionally pale blue.
} 


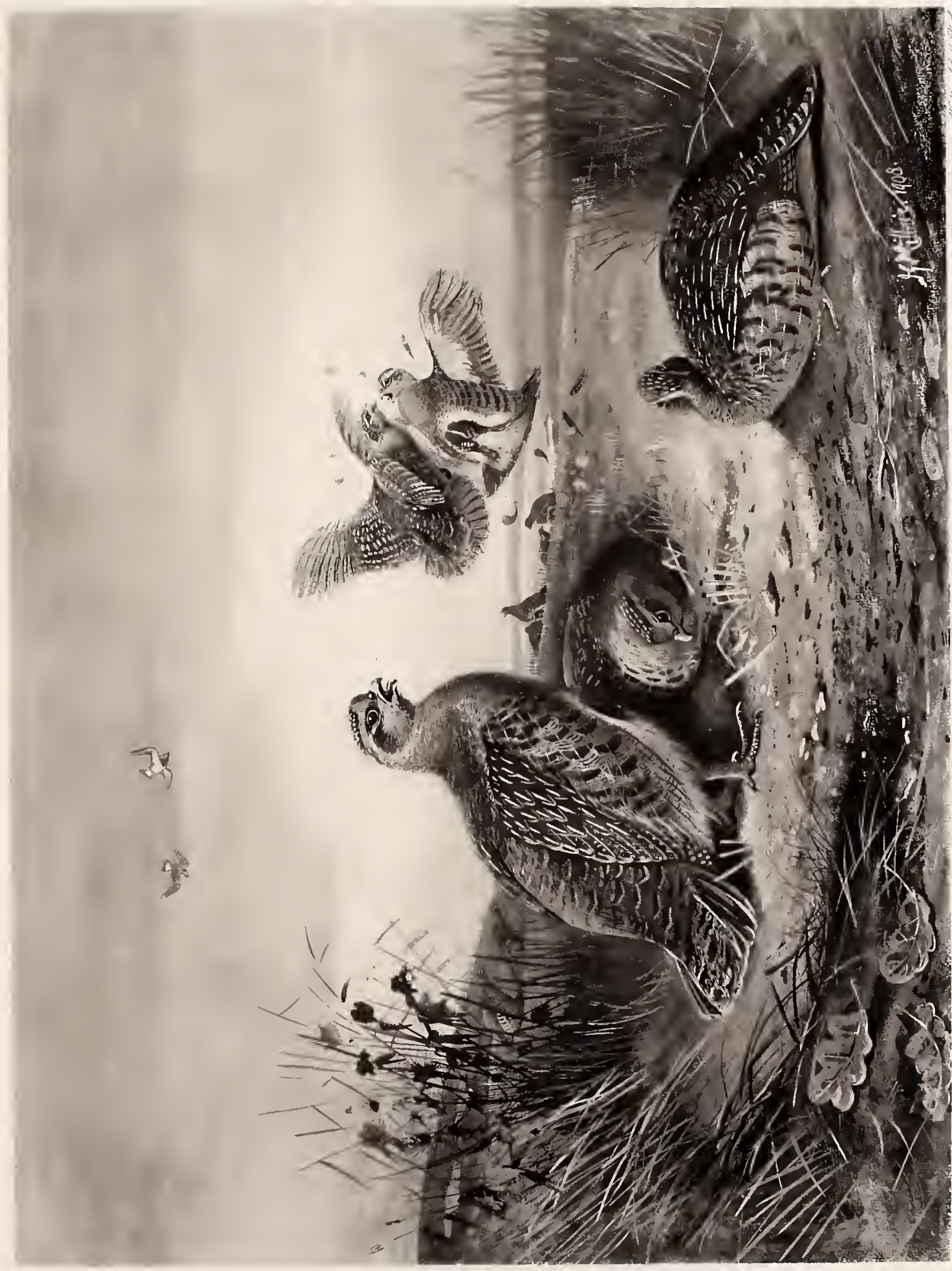





\section{The Common Partridge}

Common Partridge deserted her nest and never returned, whilst the red-leg came back and successfully hatched off her brood.

Some keepers and sportsmen think it unlucky to find a Partridge's nest, probably for the reason that the hens are apt to desert; and yet there are many instances on record of females being taken from their nests and handled and replaced without subsequent injury, the explanation being easy to all who closely study birds and animals and make allowance for temperamental diversity.

May is the month when English Partridges lay their eggs. There are instances, as recently as the year I89I, of a brood of Partridges being discovered at Longframlington in Northumberland, in the middle of January, and in exceptional springs a few hatch out as early as March and April, but such occurrences are quite abnormal and must be considered rare. I have seen a nest with fresh eggs on Sept. 3 rd in Perthshire, and there is a record of one in October. Under normal conditions, if the food supply is plentiful and the weather propitious, the hen seldom lays more than twelve eggs, although such numbers as eighteen or even twenty have been laid and incubated by a single bird. Two hens often lay in the same nest, and an instance is given in The Partridge (p. 39) of a combined total of thirty-six Partridge eggs and one pheasant in one nest, of which thirty Partridges and one pheasant were successfully hatched. When Partridge and pheasant lay in the same nest the duties of incubation are generally undertaken by the smaller bird, but there are many instances in which the pheasant hen has hatched and mothered the mixed family in her own indifferent fashion. Doubtless the larger bird could easily drive off the smaller when it comes to blows, as there is no Solomon to adjudicate in such matters, but persistence and pluck is on the side of the lesser mother, and she can usually gain her rights against one whose matrimonial duties never exercise an overburdening influence.

In three weeks young Partridges release their small bodies from the egg-shells, and are tended by both parents with scrupulous care. So mindful are these birds of their young that their affection has passed into numerous proverbs and sayings. We have all seen the intense concern and broken-winged deception of both parents as they trail their plumage in the dusty road in the hopes of luring us from their beloved chicks, and the sight is so common as to need no further description. I have not seen Partridges so bold in defence of their young as ptarmigan. They will not come so close, and the cock will not fly in your face as I have seen the hill bird do; but perhaps he knows man better and trusts him more, for in the case of stoat, weasel, fox, or dog touching the young, Partridges will actually strike them and risk their lives for the sake of the family.

With such a host of winged and four-legged foes, Partridges are ever on the watch. When moving about, the male often runs ahead and stands for minutes together acutely observing the landscape and sky. If all is safe he advances, uttering a low note like "zut-zut," whilst the female with crouching body follows with the brood, which constantly search for seeds and insects as they run. She calls them together with a low clucking note, and will run into cover with them at once on the first sign of danger. In England adult Partridges have on the whole but few enemies, as most of their natural foes are now scarce, but the chicks and poults have many difficulties 


\section{20 The Natural History of British Game Birds}

and dangers to encounter before they reach maturity. Carrion-crows, rooks, a few kestrels, sparrow-hawks, prey upon them, whilst jealous water-hens are by no means innocuous. I have known a red-backed shrike to kill young Partridges, and have seen a brood half exterminated by an emu in a park; in fact, the emu will stamp on anything that runs along the ground, having the greatest aversion to creatures of snakelike habit. It need hardly be mentioned that stoats, foxes, and occasional weasels take a heavy toll from the young Partridges. On the hard clay grounds of Surrey, Sussex, and Bedfordshire, numbers of young Partridges lose their lives by falling into the cracks of the ground that occur during a dry season. Drought and torrential rains, especially the latter, soon after hatching, seem to account for more deaths than any other cause; and it is not too much to say that the first fortnight of life is the critical time, and determines the fact whether it is to be a good Partridge season or not. Two days of heavy rain in the first week of July will destroy half the young Partridges in England, and consequently keepers and sportsmen utter a sigh of relief when the week has passed with favourable conditions. Young Partridges grow rapidly, and are able to fly a few days after being hatched.

In August Partridges spend most of the day in or alongside the corn fields, but when carrying the grain takes place they are driven to seek retreat in the adjoining rough lands or turnips, only going to the stubbles at early morn and sunset. As soon as the grain fields are clear of sheaves they have a regular habit of feeding there from dawn till ro o'clock, and then lie up in turnips until about 2 P.M., when they return to the stubbles until late in the evening, sometimes roosting there, but more generally in the adjoining "roughs." Common Partridges usually rise against the wind. Unlike the red-leg, they do not scatter and fly off at any angle or elevation, but mounting some 20 feet in the air, keep close together, all turns and "swings" being performed in unison. The flight is not of long duration, even with a strong following wind, and if carried far beyond their regular habitat they soon collect and return when disturbance has subsided. The flight may be described as "scurrying" rather than rapid, but when constantly driven over high fences Partridges can obtain a considerable speed, but not equal to that of grouse. I have often seen red grouse, black grouse, and Partridges coming on to the guns at once, and have noticed that when starting even the little birds were soon left far behind. The pace may be said to vary from 20 to 30 miles an hour, and under normal conditions seldom exceeds a quarter of a mile in distance. Flying up wind the Partridge keeps low, and takes advantage of every inequality of the ground to break the wind. If pursued under the artificial kite they may be said to "skim" the turnips, and will dodge and dive almost with the skill of a snipe. That the Partridge has good ears and can run well all know who have shot with the host that invariably follows his birds up the drills instead of across them. In such cases the Partridge takes alarm at once, and commences running as soon as the shooters enter the turnips. They can also swim well if forced to do so. The shooting of Partridges, both by driving and over dogs, is now so well understood-thanks to the many excellent books on the subject-that I need say nothing. The best book is the field of experience. Partridges are easily tamed, and make charming pets in a garden. Even wild coveys are sensible of protection, and will frequent parks and lawns if they are 


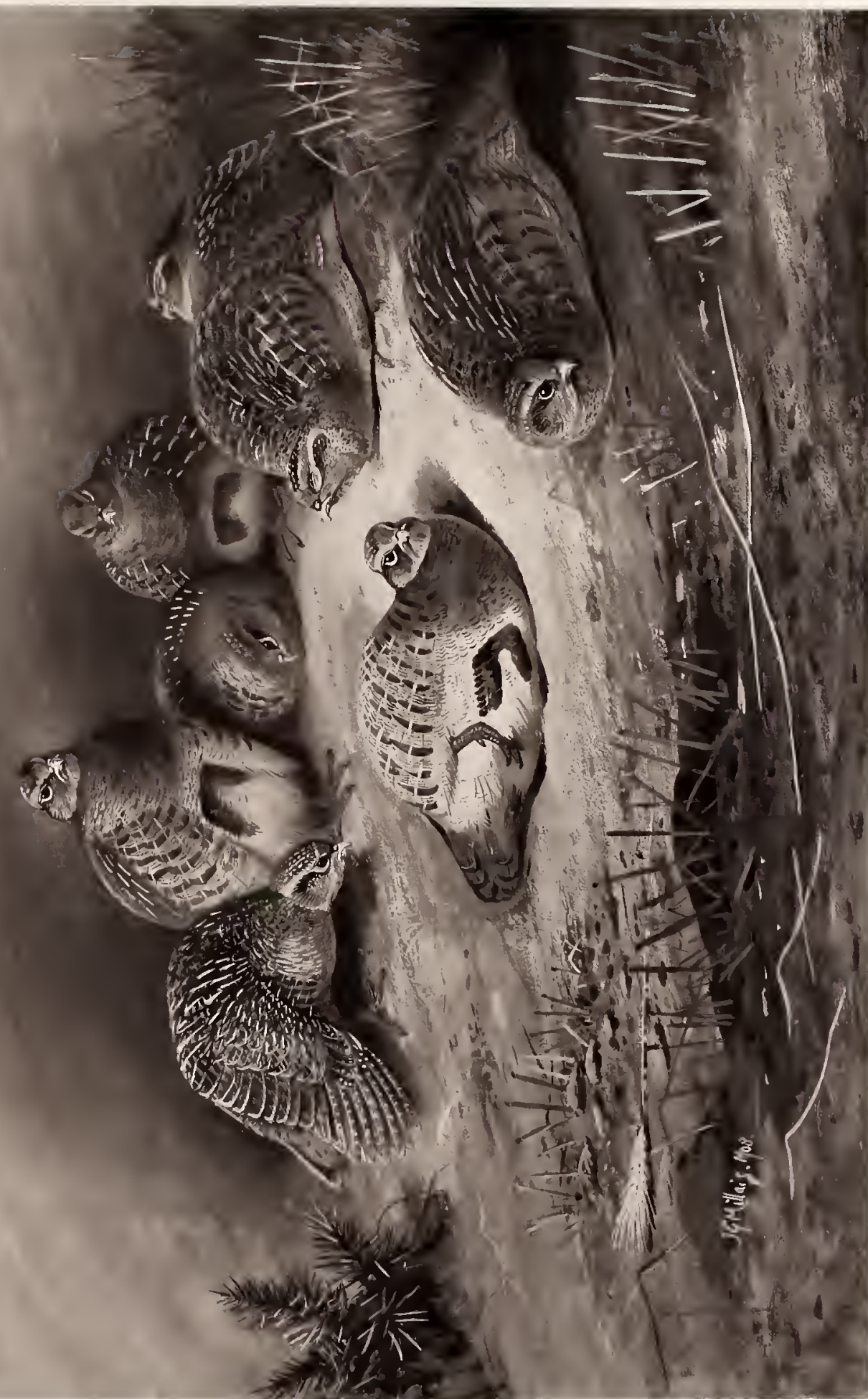

है 



\section{The Common Partridge}

fed there in the severe days of winter; but it is a curious fact that young birds reared under bantams desert the foster-mothers in September and are wilder than wild-bred birds, often forming in large flocks and entirely deserting the neighbourhood of their birthplace. I reared about fifty young Partridges under bantams one season in Scotland, and found that as soon as they left the care of the foster-mothers they were almost unapproachable, finally straying for 8 or 10 miles down to the Tay valley and scattering in all directions. I observed a similar case in Sussex lately, and other sportsinen have found that young Partridges, deprived of the restraining influence of the natural parents, have acted in similar fashion.

The furred and feathered enemies of the Partridge are very numerous, and ceaseless war must be waged against them to ensure a good stock of game birds. Rats do an infinite amount of damage. As soon as winter is over, the corn all threshed and the pigs killed, rats leave the vicinity of buildings and repair to the fields and hedgerows to breed. Unless systematically destroyed with ferret, gun, trap, and poison, they will rob every pheasant, Partridge, and wild-duck nest in the vicinity. They seem to prefer pheasant and duck eggs to those of the Partridge, and will kill the young birds, and in some instances the old ones, when sitting. Stoats and weasels, when confirmed egg-stealers, are terrible thieves, and will steal eggs singly until the nest is empty. Weasels have a habit of taking the eggs into the mole-runs they use, whilst stoats will sometimes bury their capture. Stoats and weasels also kill large numbers of young Partridges, and moles burrow under nests and cause them and their contents to fall underground. Cats and foxes also do a certain amount of harm to Partridges, and so do rooks, crows, and all the raptorials. Jays, I think, are much maligned birds. Some few will undoubtedly take the eggs of game, but they are on the whole innocuous if kept within reasonable limits. Neither have I ever seen direct proof that the hedgehog is anything but a most harmless old fellow, whose tastes are almost wholly insectivorous. Terns will attack Partridges if they venture near the breeding colony, and doubtless gulls will do the same.

The various methods of poaching Partridges are now only too well known, and if the Maxim "silencer" is applied to the .22 rifle and used by the unscrupulous, preservers of Partridges may fear the worst, unless some law is enforced to protect the game preserver. Such a weapon with its adjuncts can be carried under a coat; in use it is noiseless, and its accuracy remarkable, so that in the hands of a good shot a district could be cleared of grouse, Partridges, and pheasants, without keepers or owners being the wiser.

One of the chief causes of death amongst Partridges is the disease known as "gapes." It is the product of domesticity, and is not a natural malady. Partridges contract the disease in a marked degree where poultry farms are numerous. The parasite is the same in all cases. It attacks the windpipe, penetrating ultimately to the lungs. When viewed under the microscope it is seen to be gorged with blood and surrounded with eggs, of which the period of incubation is rapid. Nearly all birds from wrens to ostriches can suffer from "gapes," and no doubt it is conveyed from field to field by sparrows and starlings. Another common cause of mortality in Partridges is the presence of numbers of hematode worms (Heterabius papillosa) 


\section{22 The Natural History of British Game Birds}

in the two blind cæca. This disease is also found in fowls and pheasants, and sets up a fatal typhlitis. Mr. A. E. Shipley states that the earlier stages of the life of these worms is passed in water, so that it is essential that birds should have a pure water supply.

The first week in September is now more generally associated with deer-stalking than the pursuit of Partridges. Even in the south few of the birds are fit to kill, except for the table, until the middle of the month. I have seen Partridges unfit to shoot in Aberdeenshire until October Ioth, and though there is likely to be a law prohibiting the killing of blackgame until October Ist, a similar one should be enforced for Partridges north of the Tay valley.

A few words on new methods of increasing the Partridge stock may not be out of place, although the subject has been well and extensively treated in Mr. C. Alington's excellent little book, Partridge Driving, a work I can cordially recommend to all sportsmen. ${ }^{2}$ The importation of Hungarians is good, provided the new-comers are used with discretion. It is quite possible to turn out Hungarians year after year without effecting a change of blood. These imported birds almost invariably select mates from their own coveys, so that unless general egg changing is carried out by the keepers, no cross-breeding will result. The penning system is also an excellent one if conducted with due observance of the laws of Nature. Partridges as well as other birds resent the marriage-maker, and must be left to choose their own mates. No forcing of pairs together is of any use. It must be a case of spontaneous affection or no eggs will be the result. In Elginshire, on Sir William Gordon Cumming's estate, the bag has been doubled by this system, as well as in many other places in the south. A third system is to make up the nests with additional eggs-a plan, I think, invented and carried out with great success by Marlow, the head keeper at the Grange, in Hampshire. It is a curious fact that in confinement a hen Partridge will lay as many as thirty to forty eggs if she is well fed. Wild Partridges will lay almost as many if their nests are robbed with discretion. There is yet another method of increasing stock by

". . . taking away the wild partridge's eggs as she lays them, incubating them under domestic hens, and when a number (greatly in excess of one partridge's laying) are chipped, and within twelve hours of hatching, they are taken to the robbed nest of some sitting partridge and there deposited. With the frequent assistance of the cock bird, who never sat before, but is always ready to do so when the chip-chip of the shell gives him female confidence in results, large coveys are hatched off as easily as small ones. The importance of all this is that the sitting bird has not necessarily been expending her energies, and tempting foxes and vermin, for more than ten days, instead of for the customary twenty-four. She has only been sitting on clear pheasants' eggs, which would never have hatched in any case, and have been thoughtfully provided to keep her brooding instinct alive, so that her own eggs have escaped danger altogether.

"In the pens, or with this Newmarket system of preserving, vermin and the weather, the flood, the frost, and the thunderstorm are set at naught. In Nature many a poor partridge, and grouse too, comes back to her bad eggs after having been flooded off, and sits, and sits, until she is a rag of bones and feathers, doomed to die by her one all-pervading brooding

1 The French system of rearing Partridges is also well described by Mr. W. H. St. Quintin in the Field, Aug. 26, 1899; and Oct. 7,1899 . 


\section{The Common Partridge}

instinct. Just such birds have also been flooded off their bad pheasants' eggs, but when the waters have abated have returned, and with their return their own live eggs and others are given to these proud parents of children not their own. So far partridge preservation has gone on without the birds suffering in wildness in the slightest degree, since they never know the difference, and hand-rearing is not in either case resorted to." I

A French preserver has lately discovered that the cock Partridge may be utilised to as great an extent as the hen in the case of hand-reared broods, and this principle is being largely used on the Continent. As soon as the young are hatched they are allowed to run about in front of a cage where a Hungarian cock is kept. Under the doorway is left a space for the young to run in and out. In a very short time they are adopted by the male foster-parent, who is presently allowed to go free with his adopted family. The system is said to work very well, as it avoids all the dangers of early life.

Enormous numbers of Partridges are killed in the eastern counties of England, whilst parts of Hants, Yorks, and Notts are scarcely inferior in the stock of their birds. In no estate in England have such immense quantities of Partridges been shot as at Holkham, in Norfolk. During the years when walking up was employed, 3308 birds were killed in 1868 , and 3385 in 1869; but after 1880 , when driving was exclusively employed, the bag increased considerably; the two best years until recently being 1885 ( 8100 Partridges) and 1887 (7512 Partridges). These records were overtopped at the Grange, Lord Ashburton's place in Hampshire, when 4I09 Partridges were killed in four days in October 1887 by seven guns, whilst a second week yielded 2604 birds to six guns, thus averaging 420 brace per day for eight days' shooting. Eight days' shooting in 1892 at the Grange produced 4746 Partridges. Even these gun records are surpassed by four days' shooting at Holkham in 1905, of which LieutenantColonel the Hon. W. Coke kindly sends me the following particulars:-

SHOOTING AT HOLKHAM, IgO5.

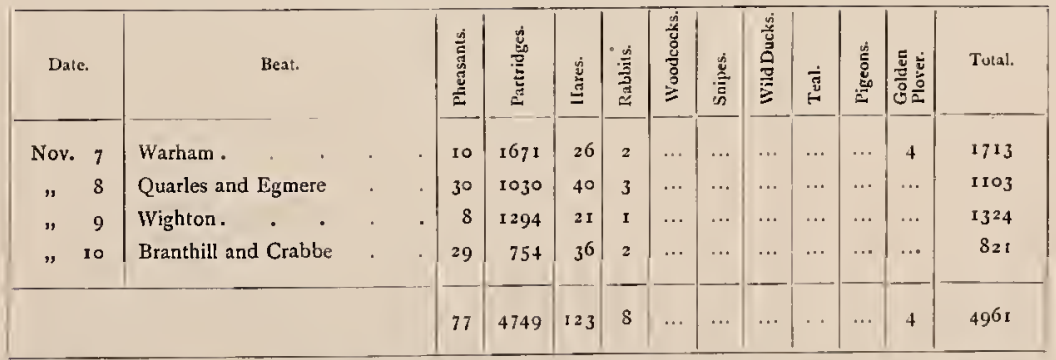

Eight guns: Prince Frederick Duleep Singh, Colonel Custance, Major A. Hood, Major Hon. Charles Willoughby, Mr. W. Forbes, Mr. W. Barry, Lord Coke, W. Coke.

At Stratton, in Hants, 530 brace of Partridge have been killed in a day. Longford has produced 400 brace and Witchingham (Norfolk) 500 brace in the same time, and lists of this kind could be extended to several pages. 


\section{24 The Natural History of British Game Birds}

Bags of over two and three thousand brace per season have often been obtained in Norfolk, Suffolk, and the Newmarket district of Cambridgeshire. In no place have I seen such swarms of Partridges as at Horse-heath near Newmarket, where I had the pleasure of shooting one day with the Duke of Fife. We killed 250 brace in a short winter day, and if the guns had been good should have doubled the bag. Sixmile Bottom, Chevely, Chippenham Park, Ickworth, Stetchworth, Lulford, and Brabraham, are all remarkable both for pheasants and Partridges, and I have had many delightful days at the little brown bird at the last-named estate as the guest of my dear friend, the late Robert Bovill. Extraordinary bags of Partridges have also been obtained at Elvedon, in Norfolk, both during the time of the late Maharajah Duleep Singh and the present owner, Lord Iveagh; also on Welbeck estate in Nottinghamshire, belonging to the Duke of Portland. I think I am correct in saying that 700 brace were obtained there in one day. In Scotland, Wigtown, ${ }^{1}$ East Lothian, ${ }^{2}$ Forfar, ${ }^{3}$ and Perthshire have produced bags that would satisfy the most greedy shooter, but the taste for raising immense quantities of game has increased of late years, and may do so for a time; but there is a limit, and that limit has been reached for the best sportsmen, who are now inclined to revolt against artificial aids to increase the stock, which is often the only method by which enormous totals can be achieved.

In Hungary the rearing of Partridges is carried to an absurd length, in the desire to eclipse records. We have only to look at the numbers of Partridges killed and the methods employed on the estates of Prince Trautmansdorff and the late Baron de Hirsch, where bags of 1000 brace per day were almost common, to see how artificial a genuine sport may become.

By the expenditure of immense sums of money, and an army of beaters harrying the birds to an unfair extent, 2870 Partridges have been killed in a single day by one of the late Baron de Hirsch's parties, and no fewer than 17,048 Partridges in one season (1892). When all is said and done, I doubt very much if the noble baron got one-fifth of the pleasure out of his much-advertised pageantry as some humble sportsman has found in a few fields where birds were wild and straight shooting a necessity.

Certain varieties of the Partridge are common, such as all buff and those with white wings or "pied," but all other variations must be considered rare. I have only seen about twelve or fourteen quite pure white examples. A regular "irregularity" is the variety in which the chestnut or blood-red suffuses a greater part of the entire plumage. When first noticed early in the last century it was supposed to be a distinct species, and was named Perdix montana (Brisson), or the Mountain Partridge, but since that date dozens of examples have been killed in different parts of England, Scotland, and Wales. It is also of frequent occurrence in Norfolk, Staffordshire, and Salop. I have seen at least twenty examples from Northumberland alone, and there are fine specimens set up by the late John Hancock in the Newcastle Museum. Mr. Walter Rothschild also possesses a fine series of this variety, mostly from foreign

1 Monreith is famous for its Partridges, and one gun has killed roo brace in a day there.

2 The Archerfield, Gosford, and Yester Estates produce great numbers of Partridges annually.

3 Glamis, the Dalhousie estates, and Fothering ham, are about the best I'artridge grounds in Forfarshire.

4 I am indebted to Mr. John R. B. Masefield for his paper on the occurrences of the rufous variety of the Common Partridge in Staffordshire, where a number of instances have occurred. 
sources. I have seen three or four Scotch "blood-red" Partridges, some almost black, so great has been the tendency towards melanism, but never what may be termed a genuine melanotic variety. ${ }^{1}$ In all cases the breast with the dark horseshoe is nearly always normal, as well as the light chestnut face." So recently as 1909 a specimen of this variety from Northumberland is noted in the Field, and it has a tendency to keep recurring in the same district. In fact, if the records of the various counties are searched, we should find that the rufous or blood-red variety of the Common Partridge has been found in all parts where these birds are common. It seems that "erythrism," as it is called, is more persistent in the species than amongst other birds.

The most remarkable variety I have seen is one I bought from a fishmonger in Perth, near which town it was killed in 1890 . The general colour is a mixture of dark brown and dove colour, with the chestnut parts of the face cream. The wide flank bars are sandy and the feather centres of the scapulars white; tail pale brown, with belly and horseshoe normal. The effect is strange but somewhat beautiful. I have another from the same district, steel-grey over all the back and scapulars, with the tail pale sandy brown heavily barred with black. Sandy buff varieties seem to be fairly common in Perthshire, as I have killed five or six at different times. It seems a pity that variations of Partridges and other game birds should be shot before they have obtained their adult plumage, as they generally are, because the mature varieties are often interesting and sometimes beautiful, whereas immatures are the reverse; but it is difficult to prevent a gunner from firing at something he has never seen before.

M. Suchetet, who has devoted much time to the study of the hybrids of European birds, considers that the interbreeding of the Common and the Red-legged Partridge has so far been imperfectly verified. Though I have examined a good number of so-called hybrids of the above-mentioned species, I have always found them to be varieties of the Common Partridge.

The late Mr. Stevenson was of opinion that the Common Partridge did occasionally interbreed with the Red-leg, and he assigned to this cross a bird killed in Norfolk in October 1850 . The specimen does not seem to be still in existence.

1 Mr. H. A. Digby remarks in the Field, February 7,1891 , what he calls two melanotic varieties. The first, he says, looked as if the head, neck, breast, and legs had been covered with soot.

2 Very frequently the whole of the head and neck are a yellowish buff colour. 


\title{
Genus Caccabis
}

\section{THE RED-LEGGED PARTRIDGES}

TAIL composed of fourteen feathers; feathers on leg not below the tarsal joint; first flight feather equal to the sixth, the third being the longest; sides and flanks broadly and transversely barred. The sexes are more or less similar, though the males are larger, more brilliantly coloured, and ornamented with one or more pairs of blunt spurs.

\section{THE COMMON RED-LEGGED PARTRIDGE}

\author{
Caccabis rufa (Linnæus)
}

LOCAL Names.-Red-leg, French Partridge, Frenchman; Petrisen Goesgoch (Welsh); Perdrix rouge (French); Rothfeldhuhn (German).

Adult Male and Female.-Greyish olive-brown above; breast, blue-grey; belly, rufous buff; throat, creamy buff; line of feathers over the eye, creamy white shading into blue-grey on the upper edge; crown, olive-brown, flushed with blue-grey in front ; fore-neck surrounded by a band of rich black, extending upwards and forwards to the back of the eye-black line from bright red bill to eye; eye surrounded by naked skin, bright red; ear coverts, black and buff; feathers on sides of chest and flanks barred with buff, black and deep-red in transverse lines; feet, deep red. The males are ornamented with two pairs of blunt spurs, joining one another, the upper being smaller and less blunt. The male has a total length of 13.6 in.; wing, 6.2 in.; tail, 3.7 in.; tarsus, I.7 in.; females are slightly smaller, but I have seen some females as large as males. They have no spurs.

Distribution.-The range of this fine species is South-western Europe. It is found in France, Belgium, Switzerland, North and Central Italy, and in such islands as Elba, Corsica, the Balearics, Madeira, the Azores, and Grand Canary. East of the Alps and the Apennines its place is taken by $C$. saxatilis, which also occupies Sicily. A closely allied species frequents Northern Algeria and Morocco, whilst in Spain C. nufa is abundant in parts, and has been named as a sub-species, Caccabis refa hispanica, by Professor Seoane, but scarcely warrants this distinction, as the bird is only a little brighter than other European specimens. The species was introduced into England about the year $177^{\circ},{ }^{1}$ and flourishes throughout the southern and eastern counties. In

1 Daniel in his Rural Sports (vol. ii. p. 4 ro) states that they were introduced into Suffolk by the Marquess of Hertford about the middle of the eighteenth century. 


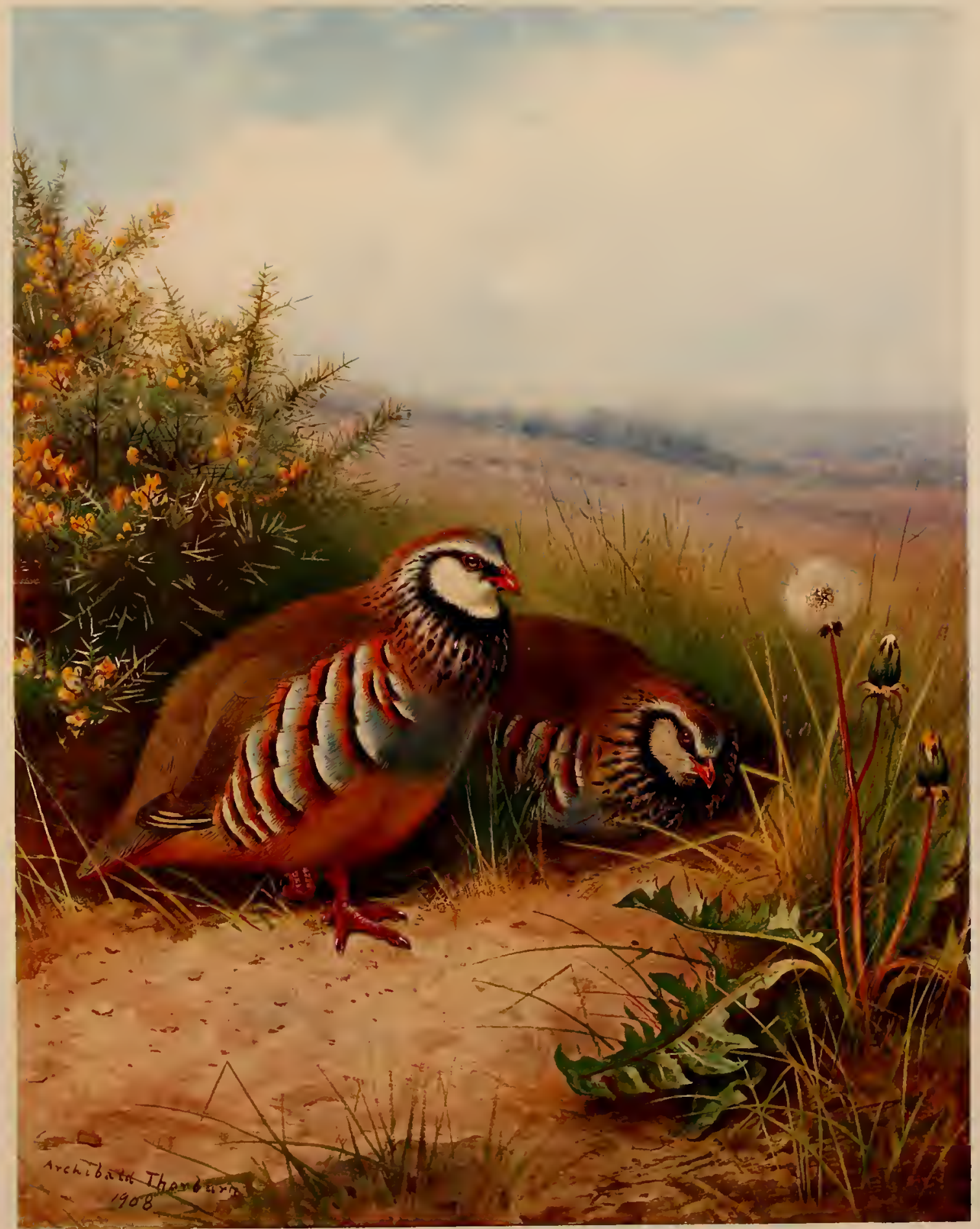

Printed by Albert Friscb-Eerlin

THE RED-LEGGED PARTRIDGE

Caccabis rufa 



\section{The Common Red-legged Partridge}

East Anglia it is so well established that it has resisted efforts to exterminate it. In the Midlands it is found in some places and is there a fast-increasing species. In Ireland and the Orkneys introduction has not met with success, nor have several attempts to establish it in the mainland of Scotland proved successful. Captain Brander Dunbar has recently turned down a few near Elgin, a county full of sandy hills and rich agriculture, and there, I feel sure, they will flourish if the experiment is repeated until the birds breed. East Lothian is another county in Scotland where the Red-legged Partridge would do well. They seem to dislike a wet country and a superabundance of grass-fields, and so will not attach themselves to the west of England and Ireland. In Wales a few are met with in all the counties except Carnarvon. In all cases they are results of recent introduction. There are some Red-legs in the Channel Islands, where they have been imported.

Habits.-The Red-legged Partridge is of a nervous, restlesss disposition. Although frequenting certain wide areas or even a few fields, it is ever on the watch and ready to run on the slightest appearance of danger, real or imaginary. Unless suddenly disturbed or hard pressed, it prefers to run, and, unlike the English Partridge, to scatter, the covey reuniting later in the day. This restlessness and running habit of the species rendered it unpopular with our fathers in the days when Partridges were shot exclusively over dogs, because many a good dog was spoilt or rendered unsteady by constantly pointing or following running birds which might be far away. Fortunately, however, destruction by constant shooting and breaking the eggs only affected the species locally, for nowadays the Red-leg is looked on with favour, owing to its use as a "driven" bird, its habit of coming on to the guns singly affording a pleasing variety. No one can treat the Common English Partridge as wanting in natural intelligence, for constant driving, carried on year after year, causes them to find out all the weak spots in a line of hedges and to swing off to corners where there are no engines of destruction waiting to greet them; but the Red-legs use their brains from the moment they espy the drivers, and when forced to rise, scatter in every direction, each bird taking a line of its own and trying all points of egress. When these afford no avenue of escape, they will pitch near the hedgerow and run to hide in dense cover or break back at the last moment. The flight is low, rapid, and, if the bird sees no opposition, straight to the point it has selected for alighting. It is not of long duration, and if the birds are put on the wing more than once, especially in wet weather or when the ploughed lands are wet, they soon tire and try to escape by running. On the clay heavy soils I have often seen old birds captured by a dog owing to their inability to fly any further. Clay will clog on their legs, especially round the spurs of the males. It is curious also to note that the tail and under parts become soaked with moisture sooner than is the case with other game birds.

The Red-leg is very partial to open sandy fields, and likes to dust in open spaces at midday, as all game birds do. It also prefers ground where there are old and dry hedgerows if there are no gorse commons, because when the fields are denuded of grain and roots it must have some place of retreat. In West Sussex Red-legs live most of their time in or about the edge of the deep "gills," except at feeding-hours. Occasionally, especially in the spring, one may see one perched on an old tree, barn, or wall- 


\section{28 The Natural History of British Game Birds}

a habit never noted amongst our native Partridges-and they have been known to nest on the top of hay and corn stacks. In the spring they are pugnacious and fight in the same way at pairing-time as our own Partridges; in fact, all their habits throughout the summer seem to be very similar, although they travel about more and walk much faster. They have often been accused of fighting and driving off the English birds. That the two species attack one another is beyond question, but that they drive off and defeat the smaller birds I very much doubt. In fact, all evidence I have been able to collect goes to prove the contrary to be the case. Three reliable witnesses have told me that in every case in which they have seen the two species in combat the English Partridge has been both the aggressor and the victor. Mr. J. Jones, who lives at Kelvedon in Essex, says: "I witnessed a desperate encounter in April this year (1907) in front of my house. A pair of Red-legs alighted on the grass near a pair of Grey Partridges, when the latter, both male and female, at once rose and attacked the new-comers. It was not an ordinary fight, but lasted for some minutes, both males and females battling with equal determination and making the feathers fly in all directions. Eventually both Red-legs were ignominiously defeated, pursued, and hunted out of the park by the smaller birds, which returned and took up their station as before." In March 1909 I saw a Red-leg come running across a field near my house; as it approached the middle a cock English bird rose and flew at it with evident anger, and chased it for some distance, when another cock Common Partridge ran out of a hedge and pursued the Frenchman until he left the field. I have no doubt that the English Partridge is disturbed more by its own species than by Red-legs.

I am glad to find confirmation of this in the few notes on the species in the Shooting volume of the Badminton Library, which says (pp. 143, 144):-

"Although in the days of shooting over pointers the 'red-legs' were naturally unpopular birds, so much so that their eggs were habitually gathered for the table on some manors in Norfolk, their habits render them particularly valuable for driving purposes. Running as they do far from the approaching line of men, they are the first to leave the field and pass over the guns; moreover, their running habits cause them to become more scattered and to arrive singly rather than in coveys, thereby affording a larger number of shots. Their flight is also straighter than that of the grey birds, and they are less apt to lie close or to turn back in the face of the beaters.

"In one respect they are inferior to the indigenous species. They have decidedly less powers of endurance. After two or more long flights they are unable to rise again from the ground, and are frequently caught by the dogs at the end of a drive.

"In exceedingly cold weather they seem to become weak or lazy, and may be easily approached and shot wherever sufficient cover can be found to hide them. It is not unusual in some parts of the eastern counties to find them at this time representing one-half or even two-thirds of the total results of a day's driving. The idea that they fight or disturb the other birds during the breeding season may be regarded as a popular error. Of the two species the grey bird is decidedly the more pugnacious. The nests of both are frequently found in close proximity to each other, and their eggs have even been observed in the same nest."

The call of the male is like the words "chuck-er-ra-kar" and "cluk-cluk-clukar," frequently repeated. When running, both males and females utter a sharp "kuk-kuk." When the female is calling her chicks together she will keep up a constant cry, for half-an-hour at a time, the call being louder and more metallic than at other seasons. 


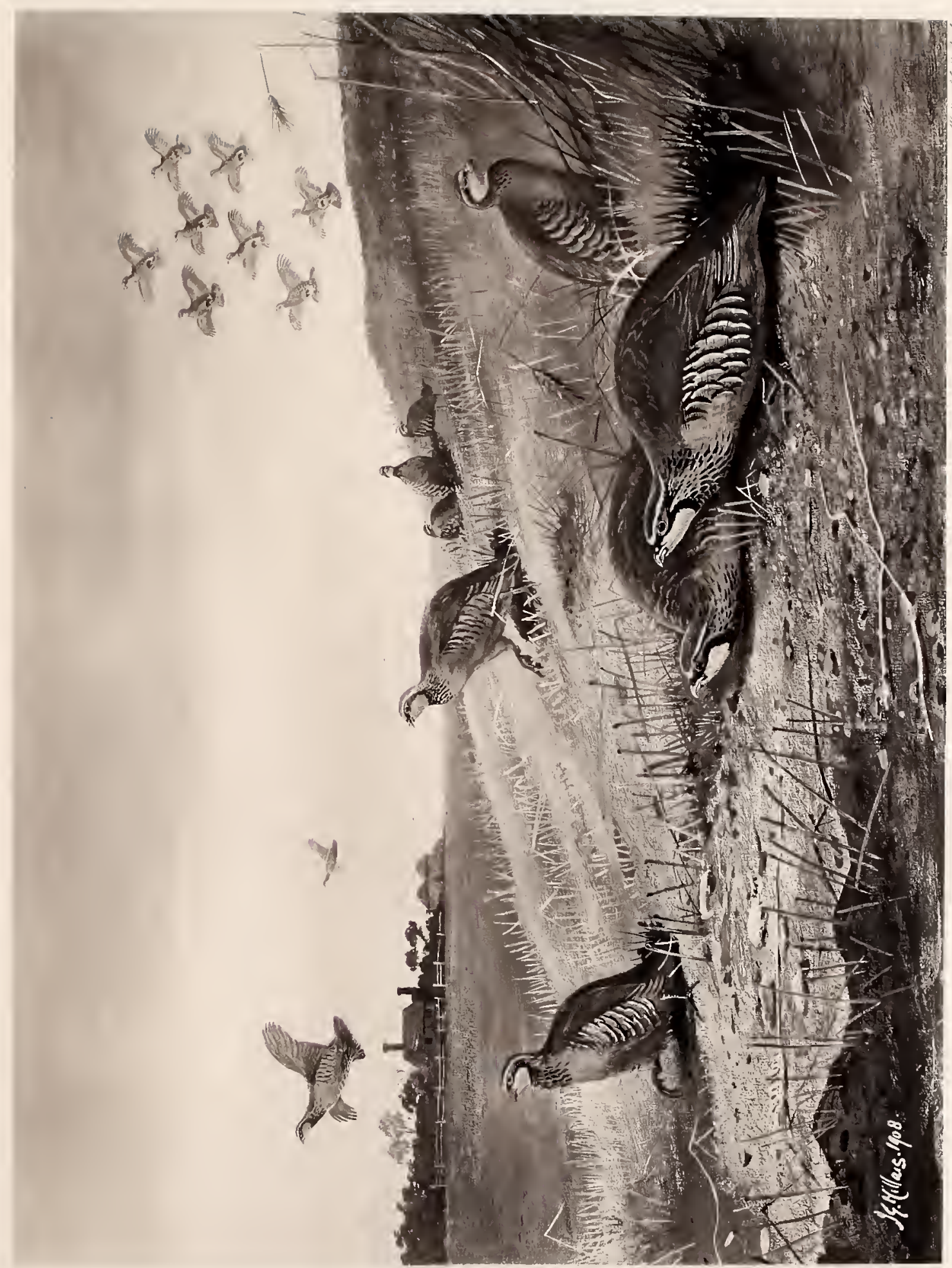





\section{The Common Red-legged Partridge}

The loosely scraped nest is often in a hedgerow, gorse bush, or grassy bank hidden in long grass. The females lay from ten to eighteen eggs, yellowish white speckled with rufous brown, size 1.55 by 1.2 inches.

Food and the growth of the young seem to be very similar to that of the Common Partridge, though the adults seem to devour more grit and coarser foods than the smaller species. Incubation lasts for twenty-three days. The pure white variety of the Red-legged Partridge is exceedingly rare-in fact, even buff or partially white varieties are seldom seen. 


\title{
Genus Coturnix
}

\section{THE Q U A I L}

\author{
Coturnix coturnix (Linnæus)
}

LOCAL NAMES.-Gearra-gort," (Gaelic); Sofliar (i.e. Stubble-hen) (Ancient British); "Wet-me-lips" (Southern English); Rhinc (Welsh); Caille (French); Wachtel (German).

Adult Male.-Bill, greyish brown; above, greenish blue; below, yellowish tip; irides, hazel; over the eye, and extending down the side of the neck, is a band of yellowish white, formed by marks on the centres of the feathers; crown, black above, with a line of pale yellowish feathers down the centre extending to the nape; nape, black and rufous-brown with yellowish centres; throat, pale chestnut-brown, with black line of feathers down the centre and across the base; ${ }^{2}$ upper breast, reddish, with strawcoloured shafts; lower breast, yellowish white; flanks, reddish, with straw-shafts edged with black markings; scapulars, back, and tail-coverts, brownish red with black markings, and yellowish shaft stripes. The first three feathers of the wings are of nearly equal length, the first a little longer than the third, and the second the longest. Greater and lesser wing coverts, pale rufous-brown streaked with brown and yellowish grey; primaries, dusky brown, with the outer bars yellowish red; legs, toes, and claws, greyish yellow-brown. The black patch on the throat is not acquired until the second year. Tail of fourteen feathers, dark-brown and barred with yellowish white.

Adult Female.-Paler in general colour than the male; the throat being white and without the crescent and black patch. The breast is marked with small dark spots on each side of the straw-coloured shafts; wing coverts barred with yellowish white. Length, 7 in. ; wing, 4.4 in.

Distribution.-The Quail is found in summer as far north as lat. $65^{\circ}$ on the Continent. It breeds fairly regularly in the Faroe Islands as I am informed by Mr. Müller. For the most part it is a migratory species, visiting the Mediterranean provinces and Syria, Egypt, in inmense quantities in spring, occurring in some parts in such multitudes as to cover the land. As they did of old in Sinai so they come north to-day, and are captured in tens of thousands by the natives of Egypt, Syria, Arabia, North Africa, and the islands of the Mediterranean, \&c. In winter many reach Madagascar, Mauritius, and even South Africa, whilst on the West it occurs regularly on the Cape Verde Islands, the Canaries, Madeira, and the Azores. It is a regular visitor

2 Gearr is a word of doubtful meaning, often used for birds and mammals ; gort means "famine." The application of the name may be derived from the story of the Israelite wanderings in the desert.

"Mr. Grant gives the throat as "white, with a black anchor-shaped mark down the middle." I find, however, that most British killed males have the throat chestnut-brown. 


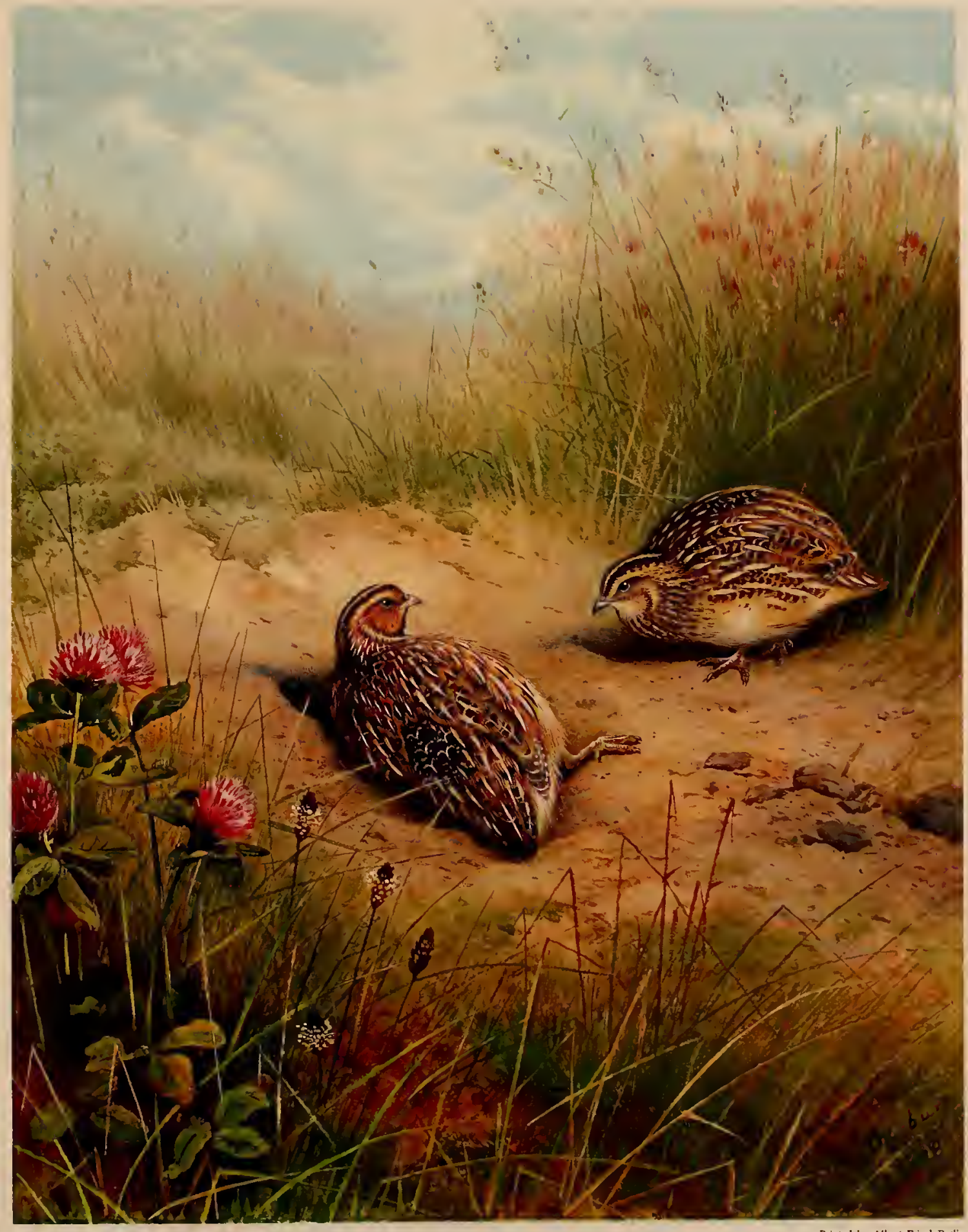

Priated by Altert Friach.Berlin

THE QUAIL

Coturnix communis 

as well as resident in Spain," France, Germany, and is also widely distributed over temperate Asia, where it crosses the highest ranges of mountains. It also visits Japan," Formosa, China, Burma and North-eastern India, but seems to avoid Southeastern Asia.

If we study closely the local records of the British Islands, where it occurs irregularly in all parts from the West of Ireland to East Yorkshire, from Cornwall to the Shetlands, we find that the Quail is subject to sporadic migrations, and that it is only residential in certain districts for a term of years. The same story is repeated throughout England, Ireland, and Scotland. Quails have come regularly year after year to the same fields, and there nested, whilst in many cases they have braved our northern winters and remained for several seasons, only to disappear for a while and again return. On the whole, however, with the change in the external character of our Southern and Midland counties, the Quail is a far less frequent visitor then formerly, and every year fewer remain in the places where they have bred. Drainage and high cultivation are of course responsible for this to a certain extent. To take only one instance of this. Quail were resident in considerable numbers in the valley of the Ribble in Lancashire until twenty years ago. Now they come fairly regularly as summer migrants, but do not stay after October. Every now and again we receive a big migration of Quail; and such occurred in 1870 , when the birds were abundant from East Anglia to Pembroke and Cornwall; in 1885, when large numbers came to the whole of the Midlands and as far north as Lancashire; and again in 1893. After each of these "bumper" seasons numbers of Quail stayed on and were shot in the following winter. Cambridgeshire, Norfolk, Suffolk, Essex, Lincolnshire, West Yorkshire, and Lancashire and Shropshire, have always been favourite resorts of the Quail. I can remember when I was a boy they were common and resident at Condover near Shrewsbury, and twenty years ago they were equally numerous on the Earl of Dartmouth's estate near Wolverhampton. Throughout Berkshire, Kent, Surrey, Sussex, and Hants they are local and scarce.

Northwards the Quail becomes less numerous, and may be regarded as a somewhat rare visitor to Scotland. In the southern counties of Scotland it is irregular; but I have reason to believe that it breeds in Perthshire every year as well as in Wigtown and Ayrshire. In the West of Scotland it is a very rare species, except in Kintyre, where it has often been killed in the autumn. In the north-east it has bred on several occasions in the low grounds of Sutherlandshire, especially about Dunrobin, and has occurred and nested near Wick. In north-west Ross-shire it is very rare, but has occurred a few times. Numbers of Quails have bred in Aberdeenshire at different times, and a few in Kincardineshire, where it may be claimed as an irregular visitor.

In North Uist it is described as "very rare";" but it has bred at Newton "and at

1 Mr. Ogilvie Grant states (Game Birds, vol. i. p. 182) that " a curious variety or semi-melanistic form of C. colurnix occurs in Spain in the marshy neighbourhood of Valencia. A male in the British Museum has the general colour of the plumage black, and the female has the under parts suffused with sooty brown."

2 Both in Japan and China occurs a local form known as C. japonica, with which the migratory Quail interbreeds. There is also another local form with a chestnut throat in South Africa $(C$. capensis), which is more or less resident and breeds with the visiting species.

3 A Fauna of the Outer Hebrides (p. 117). One was shot in Lewis in 1909, and reported in the Field.

- See Ibis, 1871 , p. 112 


\section{32 The Natural History of British Game Birds}

Stornoway in Lewis. It seems that the Quail has been noticed more frequently of recent years in the Orkneys, and from what peasants have told me it is an almost annual visitor at Pomona, where a few have been shot at different times. I think that it is more likely to stay in Orkney during winter than on the mainland, owing to the fact that snow seldom lies on these islands for any length of time. During twelve years' shooting there I have never come across a Quail, but often heard of individuals being seen. A specimen occurred in North Ronaldshay in July 1885.

The species seems to be an irregular visitor to Unst in the Shetlands. Saxby states that a nest containing ten eggs was found there in September 25, 1868, whilst Mr. J. Ferrier, writing in the Annals of Scottish Natural History, I894 (p. I 16), states, "Numbers of Quails bred in Unst this season. I have not known the bird to breed here before." It has also been killed near Scalloway. To Wales it is an irregular summer migrant, and was numerous there in the big years of 1870 and 1893 . In its sporadic migrations it is rarest in Anglesey and Carnarvon, and commonest in Flint and Denbigh.

In Ireland it is described by Messrs. Ussher and Warren as "common until 1850 or later, when it was found at all seasons; it then diminished in numbers until it reappeared temporarily in 1892 and some subsequent summers." Giraldus and subsequent writers reported it as numerous in Ireland, and, possibly owing to the growth of wheat, Thompson found it to be an increasing species in 1831 . It seems it has been most abundant previous to 1845 . About 1848 large numbers of Quails were to be met with in the stubbles, and in Sligo bags from five to ten brace were frequently made at Easky. "The birds often frequented," Messrs. Ussher and Warren state, "rough elevated ground full of furze, but were particularly attached to the small holdings of the peasantry, where they could feed on the seeds of various weeds, and lurk in the headlands and straggling fences. In such situations Quails were to be met with on the edges of the bogs, but did not resort to the latter; consequently their haunts were circumscribed in those western counties, which are chiefly unreclaimed, but whether in Kerry or in Mayo they were common on cultivated ground. Maritime counties were frequented as well as inland districts; thus Northern Tipperary and the adjoining counties abounded in Quails, and so did Louth and Antrim; and it would be hard to say whether they were most common in the province of Munster, of Leinster, or of Ulster." After 1853 Quails seemed to have decreased in Ireland, but still seemed to be common until 1860 in certain localities. This decrease continued until the seventies, when Quails became rare except in Louth and Wexford. After 1880, except for rare sporadic cases of nesting, the Quail seems to have avoided Ireland in migration until the end of 1891. In 1892 and 1893 , when there was also a big migration to England and Scotland, Quails reappeared in some numbers in Ireland. They were reported from eighteen counties and bred in Louth, Fermanagh, and Antrim. In I894-5 Quails were scarce, but numerous again in 1896 in several widely separated districts. In 1899 they came again, and will doubtless do so at irregular intervals in the future.

During the last decade Quails seem to have lost their "resident" character in Ireland as they have in England, whilst their summer visits have been most uncertain.

1 The Birds of Ireland, p. 234. 
This avoidance of our islands cannot, however, be wholly explained by any additional severity in the climate nor in the alteration of the natural features of the country due to the reclamation of waste spaces where food and shelter are to be found. As Messrs. Ussher and Warren point out, the cause of scarcity is more likely to be due to the wholesale netting of Quails in the Mediterranean countries in spring. These birds are used for food in immense numbers in Rome, Vienna, Paris, and London, and to supply the demand tens of thousands are annually trapped, netted, and shot. One vessel recently arrived in Marseilles having on board 40,000 Quails.

Habits.-The great spring migration of Quail moves up throughout Egypt, Syria, and North Africa in March, and reaches Malta, Italy, and the north shores of the Mediterranean early in April. They descend on such islands as Malta and Capri in vast numbers, for it has been estimated that in one season 1,000,000 Quails have been captured in Capri alone, whilst 17,000 have been sold in Rome in a single day. The birds at this season are in poor condition, and not to be compared to those shot in the autumn when grain and insect food are still abundant. However, they seem to bear confinement well, and rapidly fatten up even when packed in darkened crates. These cages are very low and covered with strips of felt or canvas, so that the males cannot see each other well enough to fight. Troughs of water, millet, and hemp supply all their wants.

Those that escape North scatter and breed in all the Southern European countries, whilst a few make their way to the British Isles, and as far north as the Faroes.

As soon as they arrive at their summer home the males commence to call and to fight, for they and all the Quail family are amongst the most pugnacious of birds. They will fight much longer and more fiercely than partridges, springing up and striking one another, in much the same fashion as the larger birds. The contests often last until one or other of the combatants is killed, or both incapacitated by exhaustion. In India a favourite pastime amongst the natives is Quail and black partridge fighting, and much money is won and lost at the game. In consequence of their fighting habits Quails are easily lured to capture or destruction by a clever hunter armed with call or tame bird. I have seen the Algerians going Quail shooting in the spring with a tame "enticer." In the spring all the natives of Southern Europe look forward to the advent of "la petite Caille."

In the latter part of the eighteenth century Quail were so plentiful in England that large numbers were snared and netted by the fowlers, who lured both males and females with a call. The following interesting description of the method as practised by our own forefathers is taken from an old manuscript quoted by Marshman in Country Life (November 9, 1907):-

"The quail is a well-known bird of passage, frequenting our cornfields in great numbers, and sometimes the meadows. They begin to sing in the month of April, and make their nests in May, building on the ground. Quails are to be taken by the call during their whole wooingtime, which lasts from April to August. The proper time for using the call is at sun-rising, at nine o'clock in the morning, at three in the afternoon, and at sunset, for these are the natural times of the quail's singing. The notes of the cock and hen quail are very different, and the fowler who expects to succeed in the taking of them must be expert in both, for when the cock calls the answer is to be made in the hen's note, and when the hen calls the 


\section{34 The Natural History of British Game Birds}

answer is to be made in the cock's. By this means they will come up to the fowler, so that he may, with great ease, throw the net over and take them. If a cock quail be single, on hearing the hen's note he will immediately come, but if he have a hen already with him he will not forsake her. Sometimes, though only one quail answers to the call, there will be three or four come up, and then it is best to have patience and not run to take up the first, but stay till they are all entangled, as they soon will be. The quail is a neat, cleanly bird, and will not run much into dirty or wet places.

"On dewy mornings they will often fly instead of running to the call, and in this case it is better to let them go over the net if it so happens that they fly higher than its top, and the fowler then changing sides and calling again, the bird will come back and then will probably be taken in the net. The calls are to be made of a small leathern purse, about two fingers wide and four fingers long, and made in the shape of a pear; this is to be stuffed half full of horsehair, and at the end of it is to be placed a small whistle made of the bone of a rabbit's leg, or some such bone-this is to be about two inches long and the end formed like a flageolet, with a little soft wax. This is to be the end fastened into the purse, the other is to be closed up with the same wax, only that a hole is to be opened with a pin, to make it give a distinct and clear sound. To make this sound, it is to be held in the palm of the hand, with one of the fingers placed over the top of the wax; then the purse is to be pressed, and the finger is to shake over the middle of it to modulate the sound it gives into a sort of shake. This is the most useful call, for it imitates the note of the hen quail, and seldom fails to bring a cock to the net, if there be one near the place. The call that imitates the note of the cock, and is used to bring the hen to him, is to be about four inches long; and about one inch thick. It is to be made of a piece of wire turned round and coiled, and covered with leather. One end must be closed with a piece of flat wood, about the middle of which there must be a small thread, or strap of leather, and at the other end the same sort of pipe made of bone as is used in the other call. The noise is made by opening and closing the spiral, and it gives the same sound that the cock does when he gives the hen a signal that he is near her."

The general habits of the Quail are very similar to the common partridge. They seem to frequent the same kind of ground and will live on much the same food. Their hours of feeding, dusting, and lying hidden are also the same, and they are most active early and late in the day.

Although the male is one of the most pugnacious of the gallinaceous birds, it would be difficult to find a more patient mother than the female. She is a very close sitter, and if carefully approached, almost any hen Quail will permit herself to be touched or fed by the hand. She is a late breeder, and does not lay till May in England and July in Scotland. The nest is a shallow depression placed in some rough cover, or out in the clover, wheat, or oat field. The eggs number from seven to fifteen, and are of a yellowish white colour, blotched or speckled with umberbrown. They measure 1.1 by .9 . inches. Incubation lasts about three weeks, and the young are nearly full grown in three weeks more.

The call of the male resembles the words "click-a-lik" or "Wet-me-lips," which has resulted in its local name, whilst the female utters a somewhat gentle note like "few-few" or " pew-pew."

Some difference of opinion prevails as to whether the Quail is polygamous or monogamous. All observations in our islands seem to prove that the male has only one wife, but it may perhaps be different in countries where females are very abundant. 


\section{The Quail}

In Ireland Quail shooting lasts from September 2oth till January Ioth, but in England and Scotland from August ist to March ist.

A certain number of Virginian and Californian Quails have been reared and turned out in this country. The last named is one of the most prolific birds in existence, as well as a first-rate object of the chase. It would be a great addition to our farms if it could be naturalised; but I fear that, except in a few favoured spots, not the cold, but the scarcity of natural food, would prove its destruction. Mr. Hugh Wormald has reared quite a large number of Californian Quails from a few pairs of birds. One hen laid 140 fertile eggs, most of which were reared, in 1908, and she has already laid 70 eggs this season (Ig09). 



\section{N DE X}

Alington, C., on increasing Partridge stock, 122 Austrian sportsmen do not shoot female Capercaillie, II Author :

Anecdote on shooting Grouse at Corriemuckloch, 54 Hybrid Black Grouse and Capercaillie seen by, 5 Observes Pheasant to eat berries, 83

On management of Grouse moors, 50

On speed and staying power of Grouse, 55

Possesses remarkable variety of Common Partridge, 125 Possesses steel-grey and blue-grey varieties of Red

Grouse, 60

Studies Capercaillie at the "lek," I I

Studies moults of Red Grouse, $3^{8}$

BEDFORD, Duchess of:

On introduction of Black Grouse to Woburn, 20

Particulars of introduction of Capercaillie to Woburn, 5

Berezowsky's Pheasant, 76

Bohemian Pheasant, 97

Booth, E. T., anecdote on P'tarmigan's nest by, $69 n$.

Breadalbane, Marquis of, letter to Author from, 4

Breadalbane, Marquis of, successful introduction of Capercaillie in 1837,4

Californian Quail, I 35

Capercaillie (Tetro urogallus, Linnæus), I segq.

Abnormal females, 17

Albinistic varieties, 17

Antagonism of unobservant gamekeepers to, 9

Bags, 7

Call, ro

Classed as wild birds, $\mathrm{I}_{5}$

Courageous in defence of young, $r_{3}$

Courtship, ro

Destructive to forests, $\mathbf{I}_{5}$

Diet, 9

Difficult to approach, I I

Difficulties and dangers of early life, 15

Distribution, 2

Early references, 3 seqg.

Eggs, 13

Extends from Great Britain to Kamtschatka, 2

Feed largely on larve and insects, 15

Females assume male plumage, 17

Flight, 8

Four distinct species, I
Capercaillie (continued).

Gregarious in midwinter, ro

Habitat in Scotland, 7,8

Habits, 5

Heavy mortality among young, 13

Hybrids, 6, 16

Incubation, 13

Kamtschatkan, I

Largest number killed in one day, 7

Letter of James VI. on rarity of, 4

Local names, I

Nervous of thunderstorms, 9

Nest, 13

Not so "obstinate" as Black Grouse, I6

Pleasure of doubling up a " high" cock, 16

Plumage of adult female, 2

Plumage of adult male, I

Plumage of young, 2

Slender-billed, I

Ural, I

Chapman, A., on courtship of Blackcock, 29

Chinese Ring-recked Pheasant, 79

Cobbold, Dr. Spencer, on life history of "gapes," 93

Cordeaux, John, on distant flights of Pheasant, 84,85

DARTMOoR, causes of decrease of Black Grouse on, 20 Derby, Earl of, Japanese Pheasants in collection of, 107

Digby, H. A., on two melanotic varieties of Common Partridge, $125 n$.

Dunn, M., on contents of crop of male Capercaillie, 9

ELLioT's l'heasant, 73

FERRIER, J., on Quail in Unst, 132

Fife, Earl of, unsuccessful experiment with Capercaillie, 4

Fotheringham, Walter, organises battue of Capercaillie, 7

Fuller, Mr., on remarkable cross, 99

Furstenberg, Prince :

Letter to Author from, I2, 13

On habits and call of Capercaillie, Ir, I 2

Gallinaceous birds, absence of scent of, when sitting, I 8

Giraldus Cambrensis on Capercaillie, 3 


\section{38}

Gordon, Seton, on :

Broken egg-shells of Capercaillie, ${ }^{3}$

Nesting, 57

Thieving habits of hoodie-crows, 70

Gould, Mr., description of male and female Chinese Pheasant, 99,100

Grant, Sir Arthur, shoots hybrid Capercaillie-Pheasant, I6 Grant, Ogilvie :

On distribution of Mongolian Pheasant, 102

On hybrid Black Grouse, 35

On moulting, $3^{8}$

On pairing of Pheasants, 85,86

On semi-melanistic variety of Quail in Spain, $13 \mathrm{I} H$

On supposed hybrids, 73

Quotation by, on Prince of Wales's Pheasant, ro5

Table showing position of True Pheasants, 74

Greyhen lays in nest of Grouse, 58

Grouse, Black (Lyyurts ttirix, Linnzus), 18 segq.

Call, 26 and $n$.

Causes of decrease, 20, 31

Courtship, 26

Crossing with Pheasant and Red Grouse, 33

Delicacy of young, 30,31

Diet, 23,32

Difficult to turn, 24

Distribution, I9

Eggs, 30

Fxtinct in Sussex and Kent, 2 I

Extract from Bulletin on hybrids, 34

Extract from Field on Pied Blackcock, 35

False courtship in autumn, 30

Females assuming male plumage, $3^{6}$

Fighting, 25, 27

Flight, 24

Flocks, 25

Fond of open spaces, 23

Habits, 23

Hens should be spared, 31

Hybrids, 33-36

Introduction to British Columbia and Newfoundland, I9

Local names, 18

Longer close season required, 32

Nesting, 30

Playing-grounds, 26

Plentiful in Dumfriesshire, 22

Plumage of adult female, is

Plumage of adult male, i 8

Plumage of immatures, 19

Rare in Hants and Wilts, 2 I

Record bag, 25

Scotland true home of, 22

Senses dulled at "lek," 28

Slow to reach maturity, 32

Speed in running, 29

Stalking Blackcock, 33

Suitable ground, 24

Summary of range in England, $20-23$

\section{Index}

Grouse, Black (continued).

Summary of range in Scotland, 22

Unsuccessful attempts at introduction into Ireland, 23

Grouse, Red (Lagopus scoticus, Latham), 37 segg.

Abundant in Scotland, 46

Albinoes, 60

Breeding dress of female, 37

Breeding dress of male, 39

Call, 55

"Carting," 59

Causes of migration, 49

Causes of scarcity in Ireland, 46

Courage of cock in defence of young, $5^{8}$

Courtship, 55

Curious specimen in Author's possession, 6o

Diet, 47

Difficulty in rearing, $5^{8}$

Disease of, 5 I

Dislike of wet, 59

Distribution in England, 43

Distribution in Scotland, 46, 47

Driving, 59

Eggs, 57

Extracts from Field on:

Diet in winter, 48

Management of Grouse moors, 5 I

Females very wild in autumn, 49

Fighting, 56

First instance of shooting, 44

Flight, 54

Habits, 47

Hen's affection for strongest male, $5^{6}$

Hybrids, $6 \mathrm{I}$

Imitation of call by poachers, $5^{6}$

Influenced by weather, 49

Interesting birds from Buxton and Broomhead Moor, 39

Jet-black phase very rare, 60

Large bags, 45

Local names, 37

Main cause of Grouse disease, restriction on shooting, 50

Monogamous, 55

Moulting, 37

Nests, 57

Old cocks the worst kind of vermin, 57

Plumage of adult female (winter):

Black form, 42

Buff-spotted form, 42

Half-barred form, 42

Red form, 42

White-spotted form, $4^{2}$

Plumage of adult male (winter-summer):

Black form, $4^{\mathrm{r}}$

Red form, 41

White form, $4^{2}$

Poaching, 59

Prefer to fly down wind, 55

Records, 59 
Grouse, Red (continued).

Remarkable bag in early days of muzzle-loader, 44

Restriction of numbers of old cocks, 57

Speed of flight, 55

Statistics of shooting in Wales, 46

Unsuccessful introduction to Shetland, 47

Varieties, 60

Vermin prey on, 60

Water essential to, $5^{\circ}$

Young, 43

HAGENBECK, Carl, introduces Mongolian Pheasant to Great Britain, I02

Harcourt, Sir W., attacked by cock Capercaillie, I 6

Harvie-Brown, J. A., on :

Females assuming male plumage, $x$

Limitation of Capercaillie, 7

Past history of the Capercaillie, 3

Suitable ground for Capercaillie, 6

Willow Grouse, 62

Hector Boetius first mentions Capercaillie, 3

Henderson, Neville, on Capercaillie at the "lek," I I

Hicks, Mr., on suitability for sport of Mongolian Pheasant, $\mathrm{IO}_{3}$

Hume's Pheasant, 73

Ijims's Pheasant, 76

Impeyan Pheasants, 15

Jones, J.: :

On fight between Red-legged and Grey Partridges, 128

Possesses hen Pheasant with spurs, $97 n$.

KEAY, James, on fights between Capercaillie, to

Klein, Professor, on "cramps," 93

Lesly, Bishop, on Capercaillie in sixteenth century, 4

Liechtenstein, Prince Henry, nesting anecdote by, 13

Lilford, Lord, on cross between Reeves's Pheasant and Common Pheasant, 110

Lindsey, Robert, on Capercaillie in time of James V., 4

Lloyd on Capercaillie in Norway and Sweden, $6 \mathrm{~m}$.

Longfield on Capercaillie, 3

Lopes, Fernandez, introduces Chinese Pheasant to St. Helena, roo

MackenzIE, Austin, describes an abnormal Grouse, 60 Macpherson, Rev. H. A., on Partridges crossing water, 1 I 5

Malloch, Mr., shoots cream-coloured female Capercaillie, I 7

Marshman on luring Quail by call, $\mathrm{I}_{33}, \mathrm{r} 34$

Masefield, John R. B., paper on rufous variety of Common Partridge, $124 n$.

Maxwell, Sir Herbert, records two Capercaillie shot in $\times 874,4$

MLeade-King, $W . O$., account of tame cock Pheasant, $S 9,90$
Mediterranean countries, wholesale netting of Quail in, 133

Meves, Herr Dr., on contents of crops of Capercaillie, 15

Micklefield, A. R., anecdote regarding Pheasants, 89

Milbank, Sir Frederick, on remarkable bags on Wemmergill Moors, 44

Montagu, Capercaillie extinct in British dominions, 4

Murdoch, G. W., on Phensant-barndoor crosses, $9^{8}$

Naumann on Pheasants' diet on Continent, 8o, 8 r

Newton, Professor, on remains of Capercaillie in caves, 2

Nix, Charles, on Chinese Pheasant, roo

OVary, disease of, in Common Pheasant, 96,97

Padwick, Henry, references to Pheasant in Latin writers, 78

Partridge, Common (Perdix perdix, Linnæus), $\mathrm{I} x \mathrm{I}$ seqq.

Birds reared by foster-mothers are wild, $\mathrm{I} 2 \mathrm{I}$

Call, i 16

Causes of decrease, I I $3, I_{1}$

Courtship, I 16

Diet, $\mathrm{I}_{3}, \mathbf{x} \mathbf{x} 6$

Diseases :

"Gapes," I 21

Hematode worms, 121 , 122

Distribution, 1 I 2

Easily tamed, 120

Eggs, I 8

Enemies of young, 120

Enormous numbers killed in England, 123

Extract from Daily Telegraph on method of increasing stock, I 22, I 23

Favourite haunts, I 5

Fine specimens of rufous variety in Newcastle Museum, I 24

Flight, 120

Furred and feathered enemies, I 2 I

Good results from penning system, 122

Good swimmers, r 20

Gregarious, $x 15$

Habits, 112,113

Heavy rain fatal to young, $x 20$

Hens fighting, 116

Hybrids, 125

Immatures, I 12

Importation of Hungarians, 122

Incubation, $\mathrm{x} 8$

In England most unmigratory of game birds, I $_{5}$

Large bags, 124

Large numbers killed by stoats and weasels, $\mathrm{I} 2 \mathrm{x}$

Local names, II I

Male foster-parents, 123

Males fighting, I 6 , 117

Methods of increasing stock, I 22

Monogamous, 115

Moorland, best for table, 1 I 
140

Partridge, Common (continuted)

Nest, I 18

Nesting-places, 114,117

Nests robbed by rooks, I I2

Numbers die from in flammation of lungs, $113 n$.

Parental affection, 119

Plumage of adult female, III, 112

Plumage of adult male, I II

Poachers' methods, 12 I

Rearing in Hungary, 124

Remarkable specimens, I25

Resent the marriage-maker, 122

Sharing of nest, Ir 9

Shooting at Holkham, 123

Suitable ground, 114,115

Tendency towards melanism, 125

Time for shooting, 122

Variations, 124, 125

Watchfulness against danger, 119

Partridge, Common Red-legged (Caccabis rufa, Linnæus), 1 26 seqg.

Call, 128

Diet, 129

Distribution, I26, I 27

Eggs, I 29

Favourite haunts, 127,128

Fighting, 128

Habits, 127

Incubation, $\mathbf{2} 29$

Local names, 126

Nest, 129

Pairing-time, I 28

Plumage of adult female, 126

Plumage of adult male, 126

Pure white variety rare, 129

Partridges, Red-legged, 126

Description, $\mathbf{I 2 6}$

Plumage, 126

Pennant on the "Cock of the Wood," 3

Pheasant, Chinese (Phasianus colchicus torquatus, Gmelin), 99, I00

Crosses, roo

Description, 99

Distribution, 100

Plumage, 99

Pheasant, Common (Phasianus colchicus, Linnæus), 76 seqq.

Accidents in flight, $\mathbf{8} \mathbf{4}$

Amorous note of cock, 83

Artificial nests, 87

Barren females, 96

Benefit to farmers, $8 x$

Can seldom be domesticated, 79

Careless habits of a hen, 87,88

Cock will answer any noise, 85

Courtship, 86

Curious behaviour of cock, 86

Curious habit of hen, 89
Index

Pheasant, Common (continued).

Damage to crops by, 8 I

Date of introduction into Ireland unknown, 79

Diet, 80,81

Diseases :

"Cramps," 93

Fowl entenitis, 93

"Gapes," 93

Pneumonia, 94

"Scurfy legs," 94

Dislike to draughts, 80

Distribution, 77

Earliest record of, in Britain, 78

Eggs, 87

Enemies of, 91, 92, 93

English writers' references to, 79

Female said to assume male plumage, 96

Female's three calls, 84

Fighting, 86, 87

Flight, 84

Habits, 79

Hen frequently kills young, 88,89

Hybrids, $97,98,99$

In bills of fare of Saxon kings, 78

Incubation, 87

Interbreeds most readily with game bantam, 97

Local names, 76

Makes use of other nests, 88

Male's call, $8_{5}$

Many rabbits in cover undesirable, 80

Mention in old Scotch Acts, 79

Mixture of hen-cock and white plumage, 97

Nest, 87,88

Numbers, $9^{\circ}$

Ovary, disease of, 96,97

Perfect Pheasant cover, 80

Plumage of adult female, 77

Plumage of adult male, 76,77

Plumage of Bohemian Pheasant, 97

Poachers' devices, 90, 91

Rearing of, in America, 77,78

"Spurred" females, 97

Suitable soil, 90

Suitable temperature for eggs, 88

Take to water, 85

Variation in, 97

Vipers as article of diet, $8 \mathbf{I}$

White cocks, 97

Pheasant, Hagenbeck's (Phasianus colchicus kagenbecki, Rothschild), 10 r

Description, ror

Imported to London market, IoI

Plumage, 101

Pheasant, Japanese (Phasianus colchicus versicolor, Vieillon), 106, 107

Breeding, 107

Call, I07 


\section{Index}

Pheasant, Japanese (continued).

Crosses, 107

Distribution, 107

Habits, 107

Plumage of adult female, 107

Plumage of adult male, 106, 107

Pheasant, Mongolian (Phasianus colchicus mongolicus, Brandt), ror seqq.

Abundance of animal food essential, roz

Appearance and attitude of male in spring-time, 104

Best in high woods, ro3

Call, ro5

Courtship, ro4

Crosses, 102, 103, 104

Distribution, 102

Plumage of adult female, Io2

Plumage of adult male, IOI, IO2

Tendency to stray, 104

Pheasant, Prince of Wales's (Phasianus colchicus princifalis, Sclater), 105, 106

Distribution, 105

Importation of, 105, 106

Plumage of adult female, 105

Plumage of adult male, I05

Pheasant, Reeves's (Phasianus reevesii, Gray), ro seqq.

Call, rog

Females uncertain layers in confinement, 108

Fierce disposition of male, 108

Great fighters, 108

Habitat, 108

Homing instinct of a cock, I Io

Hybrids, I 10

Long and sharp spurs, 107

Rapidity of fight, 108

Tail as "Westinghouse brake," Iog

Unsuitable environment in this country, 107

Pheasants, True, 74 segg.

Arrangement of species, opinions differ on, 75,76

Description of species, 74

Ptarmigan, Common (Lagopus mutus, Montin), 63 seqg.

Call, 67

Clever ruse of poachers, 71

Courting, 68

Defence of young, $7^{\circ}$

Devoted husbands and wives, 68

Diet, 68

Distribution, 65

Eggs, 69

Fear of golden eagle, 67

Fine example of leucotism, 73

Follow reindeer in Norway during winter, 68

Fond of basking in the sun, 68

Food of young, $7 \circ$

Golden eagle enemy of, 70

Great wing power, 67

Growth of young, 70

Habits, 66
Ptarmigan, Common (continued).

Home-loving birds, 67

Hybrids, supposed, 72, 73

Incubation, 69

Influenced by weather, 67

Local names, 63

Migratory in Europe and North America, 72

Monogamous, 68

Monthly changes of plumage, 64,65

Nests, 69

Observations on migration in Country Life, 72

Plumage of adult female :

Autumn, 64

Summer, 63

Winter, $6_{3}$

Plumage of adult male :

Autumn, 63,64

Suinmer, $6_{3}$

Winter, $6_{3}$

Preyed upon by hill fox, 69

Protective coloration, 64

Seek lower altitude in severe weather, 66

Shooting, 7 I

Shooting records, $7 \mathrm{x}$

Stratagem of female, 67

Unknown in Ireland, 65

Vermin check increase, $70,7 \mathrm{I}$

Young and immatures, 65

Pycraft, W. S., on enteritis among Pheasant chicks, $95,9^{6}$

QUALL (Coturnix coftrnix, Linnæus), $13^{\circ}$ seqq.

Californian, $x 35$

Call, 133, т 34

Capri, large number of Quail captured in, 133

Cause of scarcity, 133

Distribution, $\mathbf{1} 3^{\circ-1} 33$

Eggs, I 34

Favourite resorts, $\mathrm{r}^{3} \mathrm{x}$

Female a patient mother, 134

Fighting, favourite pastime in India, I 33

Great spring migration, 133

Habits, 133,134

Incubation, I 34

Late breeder, I 34

Local forms, $13 \mathrm{r} n$.

Local names, ${ }^{\circ} 3^{\circ}$

Male pugnacious, 134

Monogamous in Britain, $\times 34$

Nest, 134

Plumage of adult female, 130

Plumage of adult male, $13^{\circ}$

Rare in Scotland, I3I

Shooting in Algeria, 133

Shooting seasons, 135

Specimen shot in Lewis, I31 $n$.

Subject to sporadic migrations, ${ }^{3} 3^{1}$ 


\section{2}

Quail (contimued).

Tame "enticer" used in Algeria, 133

Virginian, 535

Wholesale netting in the Mediterranean countries, 133

RAvEnSwORTh, Lord, on difficulty of approaching Reeves's Pheasant, Iog

Redstart, female, with masculine plumage, $97 n$.

Richardson, Col. Stuart, shoots partly white adult male Capercaillie, I7

Rothschild, Hon. Walter :

Description of Hagenbeck's Pheasant, 101

On grouping of species of True Pheasant, 75

Possesses albinistic varieties of Capercaillie, 17

Possesses fine specimens of rufous variety of Common Partridge, 124

Possesses hybrid between Guinea-fowl male and Pea-hen, $9^{8}$

ST. Quintin, W. H. :

French system of rearing Partridges described in the Field, $122 \pi$.

On Prince of Wales's Pheasant, 106

On rearing of Capercaillie, 14

Sambon, Dr., on Grouse disease, 53

Sambon, Dr. L., and H. Hammond Smith, on pneumonia among Pheasants, 94, 95

Saunders, Howard, on call of Capercaillie, ro

Saxby on Quail in Unst, $\mathrm{I}_{32}$

Saxon kings, Common Pheasant in bills of fare of, 78

Seebohm, Henry, on races of True Pheasants, 75,76

Shaw's Pheasant, xoo

Shipley, A. E., on hematode worms, 122

Smith, H. Hanmond, summary of recent writings on Grouse discase, $5^{2}$

Soemmering's Pheasant, 75

Steuart-Menzies, W., Letter in Field on Willow Grouse, 61

\section{Index}

Suchetet, M., on interbreeding of Partridges, 125

Sunderland, Colonel M., on Prince of Wales's Pheasant, 106

TEGETME1ER on :

Digestive structure of Pheasant, 8 z

Hens assuming male plumage, $9^{6}$

Tragopans, $\mathrm{r} 5$

Turner, Mr., possesses cream·coloured female Capercaillie, I 7

USSHER and Warren on Quail in Ireland, I32

VIRGINIAN Quail, I 35

WALDY, J, B., on warfare of female Partridges, I I 7

Walker, Sir Peter, shoots abnormal specimen of Red Grouse,

Waterton, Charles, on:

Method of preserving Pheasants, 82, 83

Precautions against poaching, 90

Willow Grouse, introduction of, $6 r$

Wormald, Hugh, on :

Californian Quails, 135

Courtship of Mongolian Pheasant, 104

Curious behaviour of hen Pheasant, 88

Male's pairing call, 83

Plumage of young Red Grouse, $5^{8}$

Strange food of Pheasants, 8I

Yarkand Pheasant, 100

Young, Dr., on study of Grouse disease, $5 \mathbf{I}$

Zoologists differ on constitution of species and sub-species of True Pheasants, 76 
WORKS BY J. G. MILLAIS

THE NATURAL HISTORY OF BRITISH GAME BIRDS. With i 8 Coloured I'lates, if Photogravures and other Illustrations by ARCHIBALD THORBURN and J. G. MiLit.AIs. 4 to, $68,8 \mathrm{~s}$. net. *** Restricted to 550 copies, of which 516 are for sale.

THE NATURAL HISTORY OF THE BRITISH SUIRFACE-FEEDING DUCKS. With 6 Photogravures and 66 Plates (4I in Colours) from Drawings by the Author,

THE WILD-FOWLER IN SCOTLAND. With a Frontispiece in Plotogravure after a Drawing by Sir J. E. MIrurais, Bart, P.R.A. 8 Photogravure Plates, 2 Coloured Plates, and 50 Illustrations from the Author's Drawings and from Photographs. Royal 4to, gilt top, zos, net.

NEWFOUNDLAND AND ITS UNTRODDEN WAYS With 2 Maps, 6 Culoured Plates, 6 Photogravure Plates, and 115 other Illustrations by the Author and from Photographs. Royal 8vo, 215 . net.

THE MAMMALS OF GREAT BRITAIN AND IRELAND In three volumes. $4^{\text {to }}\left(\mathrm{I}_{3}\right.$ in. by $\mathrm{I}_{2}$ in.), cloth, gilt top, 3 vols., 618,18 s. net.

Vol, I Order Cheirostera, Order Insectivora, Order Camivora, With Is Photogravures by the Author; 3 I Coloured Plates by the
Author, ARchibal.D THoRBuRs and G. E. LODGE; and 63 Uncoloured Plates by the Author and from Photographs.

Vol. II., Order Caruizore (continuted) and Order Rodentio With 2 Photorravures by the Author, H. GRÖXwOLD, G. E. LODGE, an ALD THORRURN and G. E. LODGE; and 33 Uneol by the Author and from Photographs.

Vol. IlI. The completion of the Rorlestia with the Hares and the Rabbit, the Cervidut (the Deer family), the Boridic (the Oxen) and the Cetaceic (Whales), With 23 Phologravures by the Author, E. S. HODGSON, and H. Gronworn, and from Photographs; 12 Coloured Plates by ARCHIBALD THORBURN, H. W. B. DAvis, R.A., and the Aurhor, and 50 Uncoloured Plates by the Author, A. The

** Ontly 1025 copiss printed for England and America.

LONGMANS, GREEN AND CO.

LONDON, NEW YORK, BOMBAY, AND CALCUTTA 







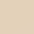





\section{.}


